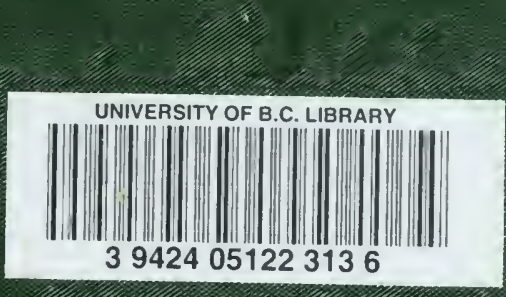

1 
(3)

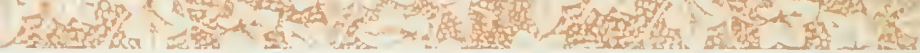

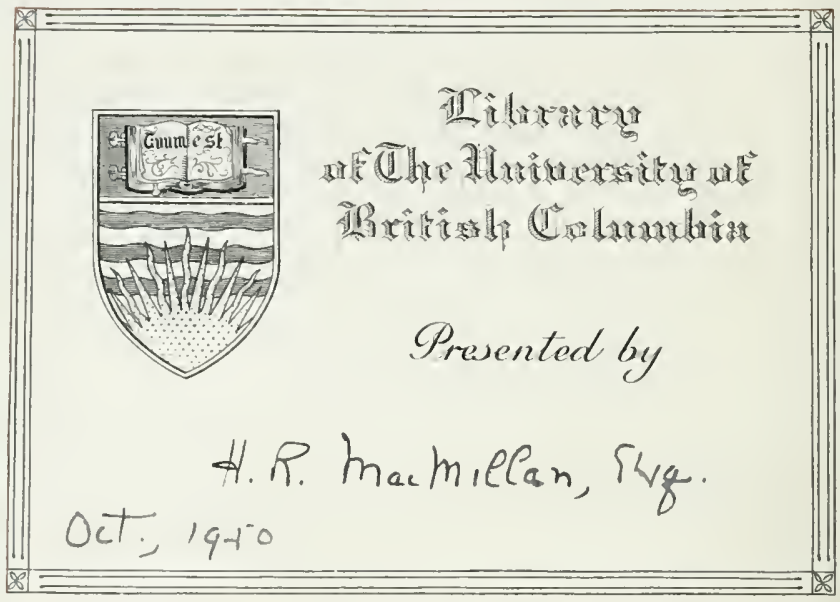

\author{
The H. R. Here Hillem \\ Gullestion in Fovestring

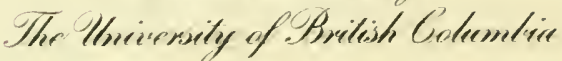



Digitized by the Internet Archive in 2010 with funding from University of British Columbia Library 


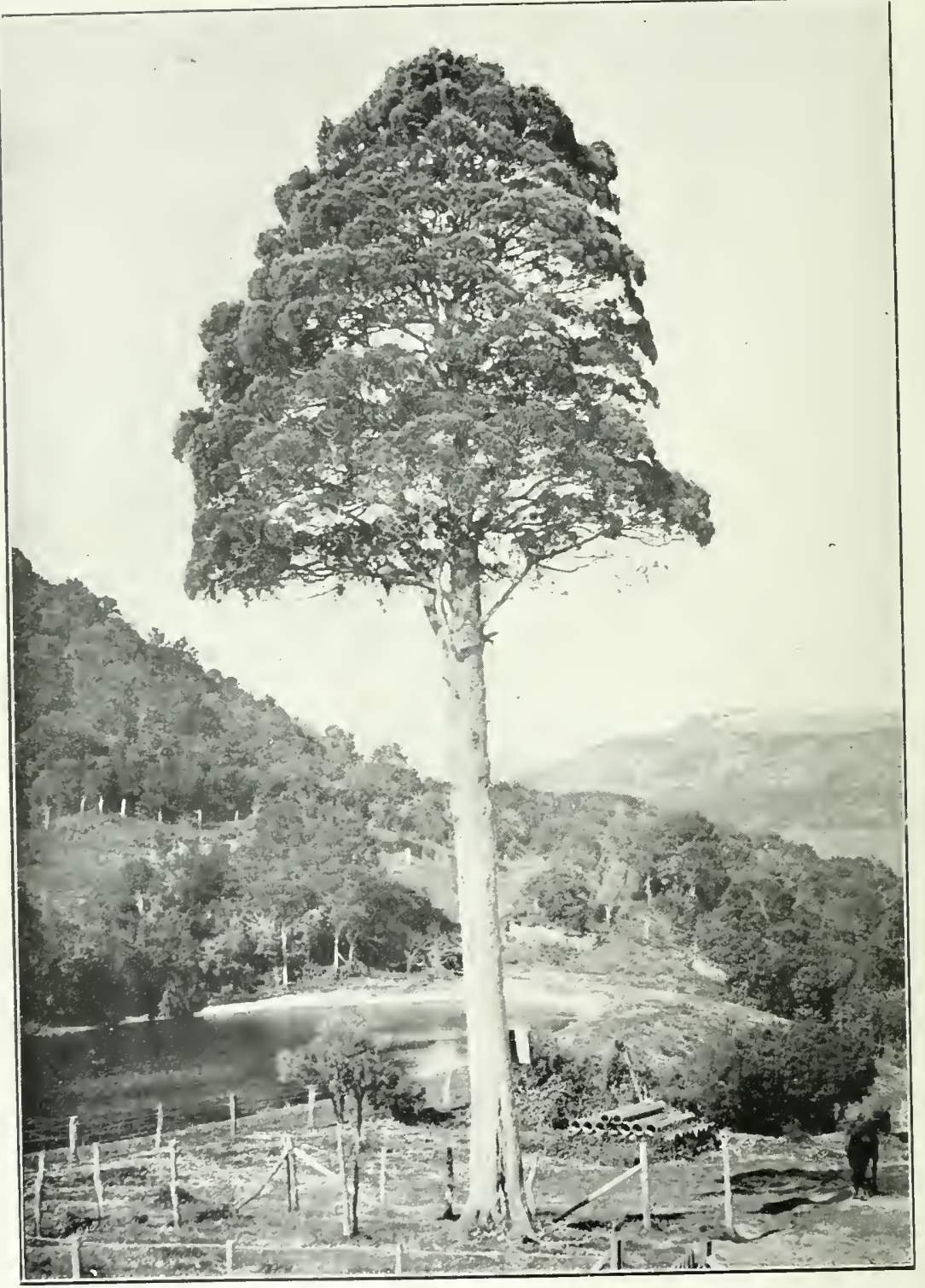

SPECIMEN OF K.IIIKITFA OR WHITE-PINE (PODOCARPUS D.ACRDIOIDES). I'late 1.]

[Frontispiece. 


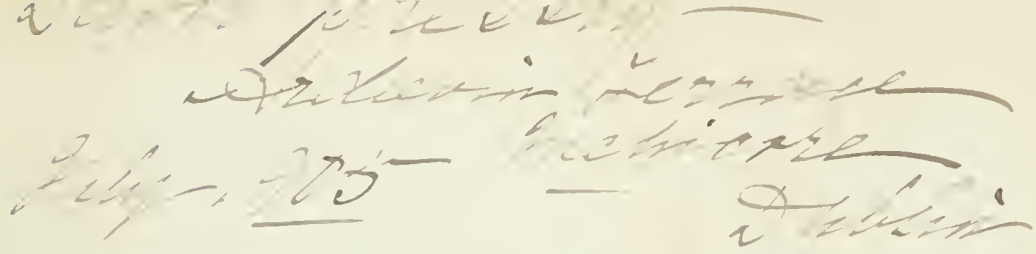

\section{TRE E-CULTURE}

Hoferger'

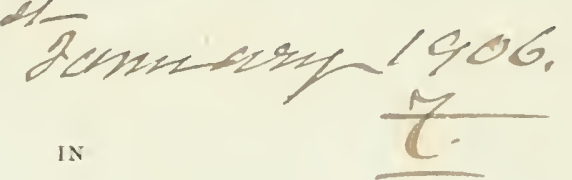

NEW ZEALAND.

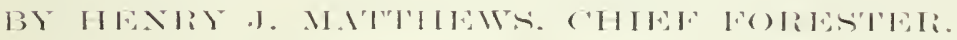

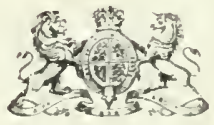

WULLINGTON.

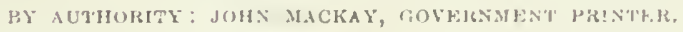





\section{PRE FA C E.}

FHE continued development of the colony and the rapid P extension of settlement has increased the demand for timber to such an extent that the question of forest-tree planting for future supplies has been forced upon the attention of the people, who are fully prepared to support systematic governmental action.

The tunctions of this Department have hitherto been confined to tree raising and planting, some five million foresttrees being raised and planted permanently per annum; and it has now been decided to assist settlers by supplying information in regard to all subjects conneeted with the raising and planting of trees, whether for ornament, shelter, or as a source of timber-supply for the future, and with this object in view the present volume has been compiled for the use of settlers. In preparing the work the author has endeavoured to present in a concise form a general outline of the subject of forestry as applicable to the colony, without attempting to be exhaustive. The tendency on the part of European writers has been to amplify and extend the subject to the exhaustion of the merest detail, necessitating the reading of much unimportant matter to find the points most required. Technical details have been avoided as far as possible, but seientific names have been mentioned chiefly because common names are often uneertain in their application.

Many works have been written on the subject, but most of these laek the simpler ant special instructions which the Department's correspondence shows to be chiefly in demand, especially amongst farmers. 
The seience of forestry has mate rapin strides within the last few years in Europe, Anerica, and India, and although excellent literature on the subject exists it is chiefly, if not entirely, applicable to Continental methods, and is consequently only of slight value to the colonist, who has to deal with the altered conditions of our insular elimate and soils. Considerable difficulty has been experienced in preparing for public information concise and explicit directions on the subject of tree-planting which shall be suitable for such variations of climate and soil as exist in the colony-semi-tropical in the north, moderate in Wellington, Marlborough, and Nelson, and semi-antaretic in the higher inland districts of Canterbury and Otago.

The best thanks of the Department are due to Messrs. 'T. W. Adams, of Greendale, Canterbury, and Alexander Bathgate, of Dunedin, for valuable suggestions and advice in the preparation of the work. Dr. Truby King has also kindly contributed a valuable paper on seaside planting.

The plates throughout the work have been reproduced from photographs taken by Mrs. H. J. Matthews.

If this book serves to convey practical information and to arouse interest in the subject of tree-planting throughout the colony its mission will have been fulfilled.

\section{H. J. MATTHEWS.}

December, $190 \mathrm{t}$. 


\section{SYNOTSIS ()H OONLENTS.}

CHAPTER I.

The Necessity fol Plantixg in New Zealand.

Results of Forcst-denudation-Importance of the Timber IndustryTimber Exports -Annual Output of Timber-Restorative Measures adopted-Shortage of Timber imminent-Destruction of Forests by

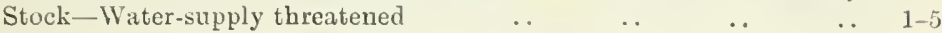

CHAPTER 11 .

TreE-SELDS.

Collecting Storiug-Approximate Number of Various Seeds in a Given Quantity-Testing Vitality of Preparation of Seeds for Sowing ..

CHAPTER III.

The Nurseri.

Selection of a Site-Aspect, Soil, Shelter-Damping off-Preparing the Ground for Seed̀-sowing - Time of Sowing - Seed-protecting Frames Shading -Wrenching - Sowing Seeds with the Roller - Sowing Minute Seeds-Preparing Seed-beds with Planks-Thickness to sow Various Seeds-Raising Tree-seeds in Boxes _. $\quad$. $\quad \ldots \quad$..

CHAPTER IV.

Transplanting Young Thees.

Care in Lifting-Sizing - Method of Transplanting-Distance between the Plants-" Lining in"-Hoeing and Weeding-Lifting Nurserygrown Trees-Puddling-Packing-Heeling-in - Time to plant . .

CHAPTER V.

TREE-PLANTING IN OpEration

Preparation of the Land-Draining-Roads and Tracks-Fire-beltsFencing-Damage to Plantation by Stock - Seasons for PlantingVarious Methods of Planting - Notching - Grubber-pits-Ordinary Pits - Marking out Pits - Boundaries of Plantations - Distance between the Trees-Density of Plantation-Results of Thin Planting -Thinning Plantations-Deep or Shallow Planting _. . 20-27

CHAPTER V1.

The Pruning of Theses.

Object of Pruning - Pruning for Timber-nroduction-Pruning Ornamental Trees-Trimming of Trees condemned-Time for Pruning .. $\quad$. 27-29)

CHAPTER VII.

SolLs.

Surface-soils-Subsoils-Formation of Soils-Chemical, Mechanical, and Organic Agencies-Trees as Soil-improvers-Classification of SoilsTrees suitable for Various Soils.. 


\section{CHAPTHR VIII}

TRF, FiнRW'H.

Definition of a Tree-Functions of Tarions Parts - The Flow of SapAnuual Rings-Spring and Summer Wood-Sapwood and Heartwood-False Rings - Formation of Bark-Knots and their Causes-

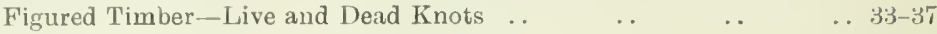

\section{CIAPTER IX.}

Pure ok Mixed Plantatiuns.

British Methods-Advantages under certain Conditions DisadvantagesInportant Considerations-Pure Planting generally recommendedContinental Methods-Necessity for Density on Margins of Plantations ..

CHAPTER $\mathrm{X}$.

Shliter p'LANTATIONS UX THE Falis.

Necessity for Shelter-Benefits of Shelter-Growth of Trees-Value of Planting as an Investment-Tree-growing versus Farming-Small Birds-Planting Poor Ground-Results of Trespass by Stock-Necessity for Careful Proteetion and Attention

\section{CHAPTER NI.}

Ralisig Plantatioxs by Direct Sumisi.

Trees reeommended for-Testing Seeds-Eucalypti and Acacia-Raising

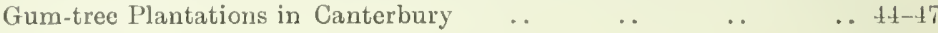

CHAPTER NII.

Wattle: Plantatiuns.

Preparing the Land-Preparing the Seed Sowing-Raising in PotsThinning-Spccies recommended-Wattle-growing in Auckland .. $47-51$

\section{CHAPTER YIII.}

\section{Heides and Hengk-PLANTS.}

Advantages of-Plints recommended-Preparing the Ground-Distance apart-Time for I'lanting-Notes on Various Hedge-plants-Tables of Number of Ilants required to plant per Mile and per Acre..

\section{CHAPTER NIV.}

SHA-COAST PLANTING.

Difficulties encountcred-Wind-Waving-Necessity for fixing SandsTrees not everywhere successful-Preparation of the Ground-Raising Trees for Seaside Planting-Season best adapted for Planting-List of Trees, Shrubs, and Grasses for Seaside Planting-Papers on Seaside Planting by James Burgess, Esq., and by Dr. Truby King . 57-69

\section{CHAPTER XV.}

S'TREET TREF-HLANTING.

Importance of-Care and Skill necessary for Suceess-Preparing Soil forPlanting - Staking-Pruning-Tree-guards-List of Trees suitable for Street-planting - Financial Considerations-Certain Species recommended 
CHAPTER XVI.

Replanting with Native Trees,

PugPs

Diffieulties to be met-Dense Shade neeessary-Suppression of Protective Growth-Age of Native Trees-Growth of Native Trees

CHAPTER XVII.

Coxiffrous Trefs.

Nomenclature, Scientific and Vernacular-- Rate of Growth in New Zealand - Brief Outline of the Various Tribes - Classification of Pines and Short Description of each Species

$80-88$

\section{CHAPTER NVIII.}

THE CORK-OAK.

The Growth in New Zealand - Species of Cork-oaks - Requirements as to Soil and Climate-Acorns-Sowing-Transplanting-Distance apart - Nurse-trees for-Shelter necessary-Growth of the Bark ..

CHAPTER XIX.

The HaRdy Catalpa.

Its Suitability for Cultivation - Worthless Timber-producing Speeies Raising from Seed - Catalpa in America - Hardiness - Timber maturing at an Early Age

CH.APTER XX.

Eucalypti: HaRny Spfcies.

IInimum Temperature recorded in New Zealand-Number of Species of Euealypti - Notes on Hardy Tasmanian Speeies suitable for Ex tensive Planting in the Colony-System of "mossing " Euealypti. .

\section{APPENDICES.}

\section{APPENDIX I.}

Alpitaretical List of Trees and Shrubs suitable for Planting IN NFw Zfaldxn.-Generie and Speeitic Names, Synonyms, and Common Names - Indicenous Country - Approximate Height of Growth - Evergreen or Deciduous - Deseription - Principal Value - Remarks re Soil and Hardiness . 101-122

\section{APPENDIX II}

Trems for Special Pcrposes. - List of Trees best adapted for the Growth of Timber for Firewood -Iust of 'Trees best adapted for the Growth of Timber for Sleepers, Fence-posts, \&c. - List of Trees best adapted for Shelter Purposes-- 1 ist of Trees best adapted for Timber Purposes

$$
\cdots
$$

\section{AHPIDIX III.}

Arallable Works ox Forestry axd Kindred SubJects. - Britisb Publications-Colonial Publications-American PublicationsPublications by Bureau of Forestry, United States Department of Agriculture

. 



\section{LTST OH ITLUSTRATIONS.}

No. of

l'late.

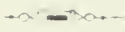

1. Specimen of Kahikatea..

2. Tiew of a Small Nursery.

(Frontispicce)

3. Preparing Seed-beds

4. Preparing Seed-beds with Plank

$\cdots$

Page

5. Seed-frames

6 Different Styles of See 7 -frames

7. Tree-seed Sowing

8. "Lining out" Trees

9. Seedling Aleppo Pines

10. "Lining out" Young Trees

11. Spruce Fir, One, Two, and Three Years old

12. Bentham's Pine, One, Two, and Three Years old

$\cdots$
$\cdots$
$\cdots$

. $\quad$. 2

13. Austrian Pine, One, Two, and Three Year's old

14. Californian Redwood, One, Two, and Three Years old

15. Forest-tree Planting in Operation ..

16. A Forest Tree wrongly planted

17. Various Systems of Planting Trees

18. Mont $€$ rey Pines " mosted" .

19. Eucalypti " mossed" ..

20. Mossing Fucalypti

21. "Lining in" Eucalypti ..

22. Aleppo Pine, "Mlossed" Seedlings

23. Canary Island Pine, "MIossed" Seedlings . .

24. A "Break" of 200,000 Austrian Pines

25. Forest-tree Planting at Whakarewarewa ..

26. A Wind-break of Prickly-coned Pine

27. Tasmanian Blackwood Seedlings "mossed"

28. Golden Akeake-A Good Shelter-shrnb

29. Bentham's Pine, Specimen

30. Totara, Seedling and Cutting

31. Cross-section of a Heavy Pine Log

32. Cross-section of a Silver Fir

33. Longitudinal Sections of Rewarewa

34.

Kowhai ..

35.

Austrian Pine

36. Specimen of Young Kauri

37. Cork-acorns germinating ..

38. Cork-oak, Seedling

39. Cork, Section of, grown in Auckland

Forestry-ii. 
40.

41 .

in Winter, Seedling

Seedling

80

42

Half a Million Seedlings at Rotorua Nursery

43. The Hardy Catalpa, Ten Tears old

44. Eucalyptus amygdalina, Seedling...

45.

46.

47.

adult Foliage

48.

49.

50.

51.

52.

53.

54.

55.

56.

57.

5 S.

59.

60.

61.

62.

$$
\text { urmigera, }
$$

Seedling..

adult Foliage

nauciflora, Seedling.. adult Foliage

Sieberiana, Seedling..

obliqua,

$$
\text { adult Foliage }
$$

regnans,

Seedling..

adult Foliage

Stuartiana, Seedling.. adult Foliage

riminalis, Seedling..

63. globulus, Muelleri, coccifera,

adult Foliage

Gunnii,

Seedling..

adult Foliage

64. Eucalypti Capsules, Fourteen Speeies

$\begin{array}{llllr}\ldots & \ldots & \ldots & \ldots & 86 \\ \ldots & \ldots & \ldots & \ldots & 88 \\ \ldots & \ldots & \ldots & \ldots & 90 \\ \ldots & \ldots & \ldots & \ldots & 92 \\ \ldots & \ldots & \ldots & \ldots & 94 \\ \ldots & \ldots & \ldots & \ldots & 96 \\ \ldots & \ldots & \ldots & \ldots & 98 \\ \ldots & \ldots & \ldots & \ldots & 100 \\ \ldots & \ldots & \ldots & \ldots & 102 \\ \ldots & \ldots & \ldots & \ldots & 104 \\ \ldots & \ldots & \ldots & \ldots & 106 \\ \ldots & \ldots & \ldots & \ldots & 108 \\ \ldots & \ldots & \ldots & \ldots & 110 \\ \ldots & \ldots & \ldots & \ldots & 112 \\ \ldots & \ldots & \ldots & \ldots & 114 \\ \ldots & \ldots & \ldots & \ldots & 116 \\ \ldots & \ldots & \ldots & \ldots & 118 \\ \ldots & \ldots & \ldots & \ldots & 120 \\ \ldots & \ldots & \ldots & \ldots & 122 \\ \ldots & \ldots & \ldots & \ldots & 124 \\ \ldots & \ldots & \ldots & \ldots & 126 \\ \ldots & \ldots & \ldots & \ldots & 126\end{array}$




\title{
TREE-CULT'URE IN NEW ZBALAND.
}

\author{
CHAPTER I.
}

\section{THE NECESSITY FOR PLANTING IN NEW ZEALAND.}

"Jock, when ye hae naetbing else tae dae, ye may be aye stickin' in a tree; it will be growin', Jock, when ye're sleepin'."

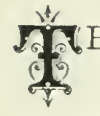

HE evils resulting from deforestation foreshadowed by such eminent authorities as the late Captain Campbell Valker and the late Professor Kirk more than twenty years ago have in many districts been verified through climatic changes resulting inevitably from the wholesale clearing of bush-clad lands. Almost every spring brings floods and freshets down the watercourses, in which the streams, fed by melting snow and spring rains, formerly flowed gradually, while protracted droughts in summer and autumn are of more frequent occurrence than formerly. Winter winds now sweep over large cleared areas, damaging alike to stock and crops. It is only by the preservation of existing forest lands and the replanting of denuded areas that it is possible to secure agricultural fertility, a lasting supply of timber, and a permanent water-supply.

Owing to the lavishness of Nature in providing such magnificent forests as existed on the first settlement of the colony, we have been accustomed to look upon the axe and fire as precursors of the plough, and to consider forest-utilisation as synonymous with forest-destruction. The chief aim of the pioneer settler was to get rid of the bush that he might grow other crops, and so vigorously had this work been carried out that in many instances the dangerline in forest-denudation has been passed before it was realised, until forced on the attention by the drying-up of springs, the flooding of creeks, and altered climatic conditions. What has been done by the pioneer settler in the more settled parts of the colony may be expected to be repeated in the newly settled districts. So long as areas of fertile bush-covered lands are available for settlement this work must proceed; but too often the intending settler is guided in his selection of land by the valuable growth of

Forestry-1. 
timber upon it, which he immediately converts into cash. When the timber is gone he finds that the land will not grow the crops he intended, but is fit only for tree-growth, and he either abandons it or disposes of it to a settler of less experience, who ekes out a starvation existence until forced to sell or otherwise dispose of his selection. Land that will grow trees more profitably than other crops should be retained as forest land, not only because it furnishes a source of revenue, but for the general benefit of the community.

The importance of the timber industry to the colony is shown in the following from the Official Year-book:-

TABLE showing Number of Sawmills in Operation, Hands Employed, Wages Paid, Quantity and Value of Timber Sawn, Value of Posts and Rails, and Total Value of all Manufactured Timber for 1900 ; also Comparison with 1895.

\begin{tabular}{|c|c|c|c|c|c|c|c|}
\hline Year. & $\begin{array}{c}\text { Number } \\
\text { of } \\
\text { Mills. }\end{array}$ & $\begin{array}{c}\text { Hands } \\
\text { employed. }\end{array}$ & $\begin{array}{l}\text { Wages } \\
\text { paid. }\end{array}$ & $\begin{array}{l}\text { Quantity of } \\
\text { Timber } \\
\text { sawn. }\end{array}$ & Valne. & $\begin{array}{l}\text { Posts } \\
\text { and } \\
\text { Rails. }\end{array}$ & $\begin{array}{l}\text { Value of } \\
\text { all Manu- } \\
\text { factures. }\end{array}$ \\
\hline $\begin{array}{ll}1900 & \ldots \\
1895 & \ldots\end{array}$ & $\begin{array}{l}334 \\
299\end{array}$ & $\begin{array}{l}6,085 \\
4,055\end{array}$ & $\begin{array}{c}£ \\
514,088 \\
323,223\end{array}$ & $\begin{array}{c}\text { Ft. } \\
261,583,518 \\
191,053,466\end{array}$ & $\begin{array}{c}\stackrel{£}{£} \\
671,048 \\
627,959\end{array}$ & $\begin{array}{c}£ \\
19,277 \\
10,998\end{array}$ & $\begin{array}{r}\stackrel{£}{£}, 268,689 \\
898,807\end{array}$ \\
\hline $\begin{array}{c}\text { Increase } \\
\text { during } \\
\text { five } \\
\text { years }\end{array}$ & 35 & 2,030 & 190,865 & $70,530,052$ & 343,099 & 8,279 & 369,882 \\
\hline
\end{tabular}

In 1901 thirty-five additional mills were in operation, and the number of hands employed increased by 733 . Auckland increased her output of sawn timber (principally kauri) from 79,464,526 superficial feet in 1895 to $109,124,543$ superficial feet in 1900 .

TABLE showing Quantity and Value of Timber exported from 1888 to 1901 , inclusive.

\begin{tabular}{rllllr} 
Year. & & & & $\begin{array}{c}\text { Quantity. } \\
\text { Sup. ft. }\end{array}$ & \multicolumn{1}{c}{$\begin{array}{c}\text { Value } \\
£\end{array}$} \\
1888 & $\ldots$ & $\ldots$ & $\ldots$ & $43,474,434$ & 177,877 \\
1889 & $\ldots$ & $\ldots$ & $\ldots$ & $42,568,600$ & 176,608 \\
1890 & $\ldots$ & $\ldots$ & $\ldots$ & $42,098,863$ & 181,689 \\
1891 & $\ldots$ & $\ldots$ & $\ldots$ & $42,824,365$ & 182,431 \\
1892 & $\ldots$ & $\ldots$ & $\ldots$ & $22,860,551$ & 87,581 \\
1893 & $\ldots$ & $\ldots$ & $\ldots$ & $26,718,046$ & 101,082 \\
1894 & $\ldots$ & $\ldots$ & $\ldots$ & $31,901,415$ & 116,116 \\
1895 & $\ldots$ & $\ldots$ & $\ldots$ & $38,297,905$ & 141,892 \\
1896 & $\ldots$ & $\ldots$ & $\ldots$ & $34,984,414$ & 133,511 \\
1897 & $\ldots$ & $\ldots$ & $\ldots$ & $39,326,396$ & 156,289 \\
1898 & $\ldots$ & $\ldots$ & $\ldots$ & $40,721,632$ & 167,510 \\
1899 & $\ldots$ & $\ldots$ & $\ldots$ & $50,425,741$ & 199,231 \\
1900 & $\ldots$ & $\ldots$ & $\ldots$ & $57,517,085$ & 233,659 \\
1901 & $\ldots$ & $\ldots$ & $\ldots$ & $71,822,369$ & 295,890
\end{tabular}




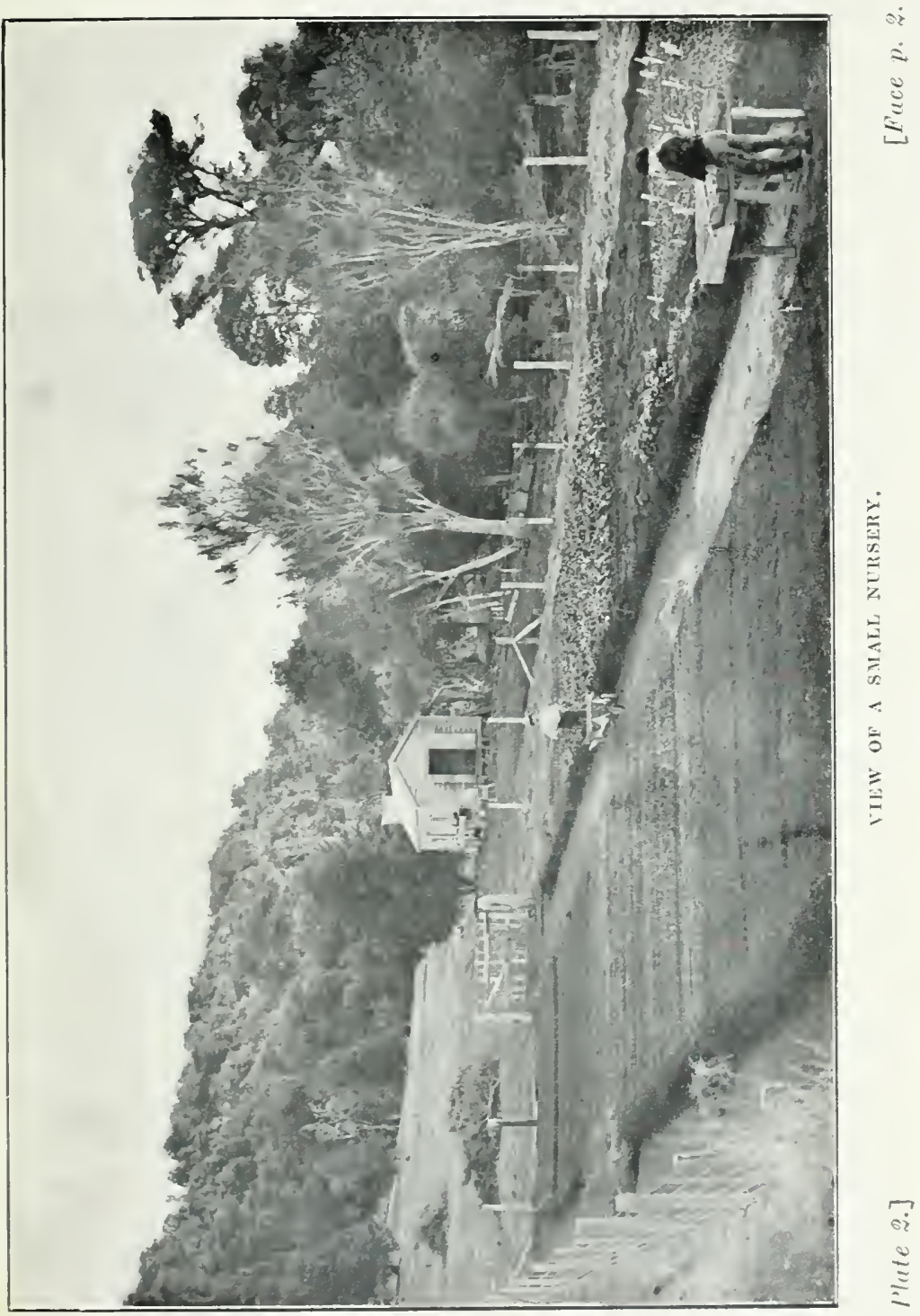



The foregoing figures show that the value of our manufactures from forest-products amounts to over one and a quarter million sterling per annum, nearly one-fourth of which is exported; while we imported 17,311,567 superficial feet of timber in 1901, valued at $£ 179,152$.

Since writing the above the Right Hon. the Premier, in his Financial Statement of 12th July, 1904, refers to the question as follows : "The interest manifested in recent years $i_{11}$ the conservation and utilisation of the indigenous forests has in no way abated. The Government has given earnest attention to this question during the past year, and has caused further investigation, inspections, and appraisements to be made of the timber in various localities. It has been ascertained that, excluding the 'Taupo district, the approximate quantity of millingtimber now growing upon Crown lands is about 20,000,000,000 superficial feet, which experts consider equal to forty-five years' supply at the present rate of consumption. It is estimated that if the milling-timber upon Native and freehold lands be fully utilised, our requirements will be satisfied for the next seventy years. Closer investigations have disclosed that the quantity of kauri timber remaining for utilisation will only last about twelve years at the present annual output. The knowledge that the timber-supplies have been so largely reduced, led to the reconsideration of the question of the timber regulations, and steps have been taken to safeguard the whole of the remaining milling-timber, and to deal with applications for the right to erect sawmills and cut out the same only after full inquiry, so as to insure that there shall be as little waste as. possible. Every encouragement should be given to private owners of forests containing nilling-timber to preserve the same, so that all resources of the colony in this respect shall be used for the common good. Planting cannot be done without a considerable outlay. The Government have consequently enlarged the operations by employing additional prison labour. We shall, however, have to incur much greater expense in providing for the future requirements of the colony. During the current financial year it is proposed to plant $5,000,000$ trees."

We have no available record of the quantity of native timber remaining uncut either on Government, Native, or private lands, but from the reports of the Commissioners of Crown Lands it is evidently becoming scarce everywhere with the exception of Vestland. In Westland, however, much of the timber is so inaccessible for want of harbours that a large proportion of it must remain uncut, owing to the high cost of bringing it to a port.

The quantity of kauri remaining on Crown, Native, and private lands in 1900 was estimated at 1,379,766,000 superficial feet, whilst during that year over $109,000,000 \mathrm{ft}$. were cut. Thirteen years, therefore (at the present rate of conversion), will see the kauri forests exhausted, without reckoning the possibility of loss from fires, which are of annual occurrence. 
Our annual output of timber is now over $261,500,000 \mathrm{ft}$. per annum, and, if we allow $10,000 \mathrm{ft}$. of timber to the acre (which is probably double the average yield), 26,150 acres of land at the very lowest computation are annually being denuded of forest to supply present demands.

What is being done by way of replanting by this Department? The six nurseries now established are capable of raising five million trees per annum. These will cover an area of approximately 1,800 acres, and in forty to sixty years it may reasonably be expected (judging by the results obtained in other countries) that each acre will finally produce $20,000 \mathrm{ft}$., or a total of $36,000,000 \mathrm{ft}$. per annum of sawmilling timber. Thinnings from this area need not be taken into consideration, as, although these will serve as sleepers, posts, \&c., we are at present considering only milling-timber's. There are also the risk of fire, disease, and the possibility (though remote) of non-success with artificial plantations during the fifty years of their growth to be taken into consideration. The coiony is therefore utilising thirteen times more timber per annum than can possibly be produced from our artificial plantations forty to sixty years hence.

The above figures show the gravity of the situation and the rapidity with which the colony is being stripped of its forests. It cannot be expected that our present annual output can be maintained until artificial plantations now being made are available; and unless our exports are largely curtailed, our forests rigorously conserved, and planting operations vastly increased there will undoubtedly come a period of complete cessation of our native timber industry at no distant date. The necessity, therefore, for settlers in this colony to prepare for their future wants as regards fuel and fencing is obvious, even if they do not undertake a portion of the more important work of growing timber for the benefit of future generations, which is possibly the duty of the State rather than of the individual.

Another phase of the subject may be mentioned-viz., the preservation of bush-clad lands at the sources of streams and rivers in order to equalise and maintain a constant water-supply. It is hardly necessary to refer to the destructive influences consequent on the indiscriminate clearing of forest lands, especially at the sources of rivers. Spain, at one time noted for its salubrious climate and the richness of its soil, is now one of the poorest and driest countries in Europe, with a rainfall of only $9 \mathrm{in.}$ per annum, owing entirely to the denudation of its forest areas. Other instances of the disastrous results caused by the reckless destruction of forests may be found in the Islands of Cyprus, St. Helena, Mauritius, and in Egypt, India, and many other countries, including divers parts of our own colony, where periodical floods frequently occur, doing immense damage to bridges, roads, and low-lying country.

Cattle, sheep, rabbits, and the wild pig are the chief agents in the destruction of our sub-alpine vegetation, and their efforts are 


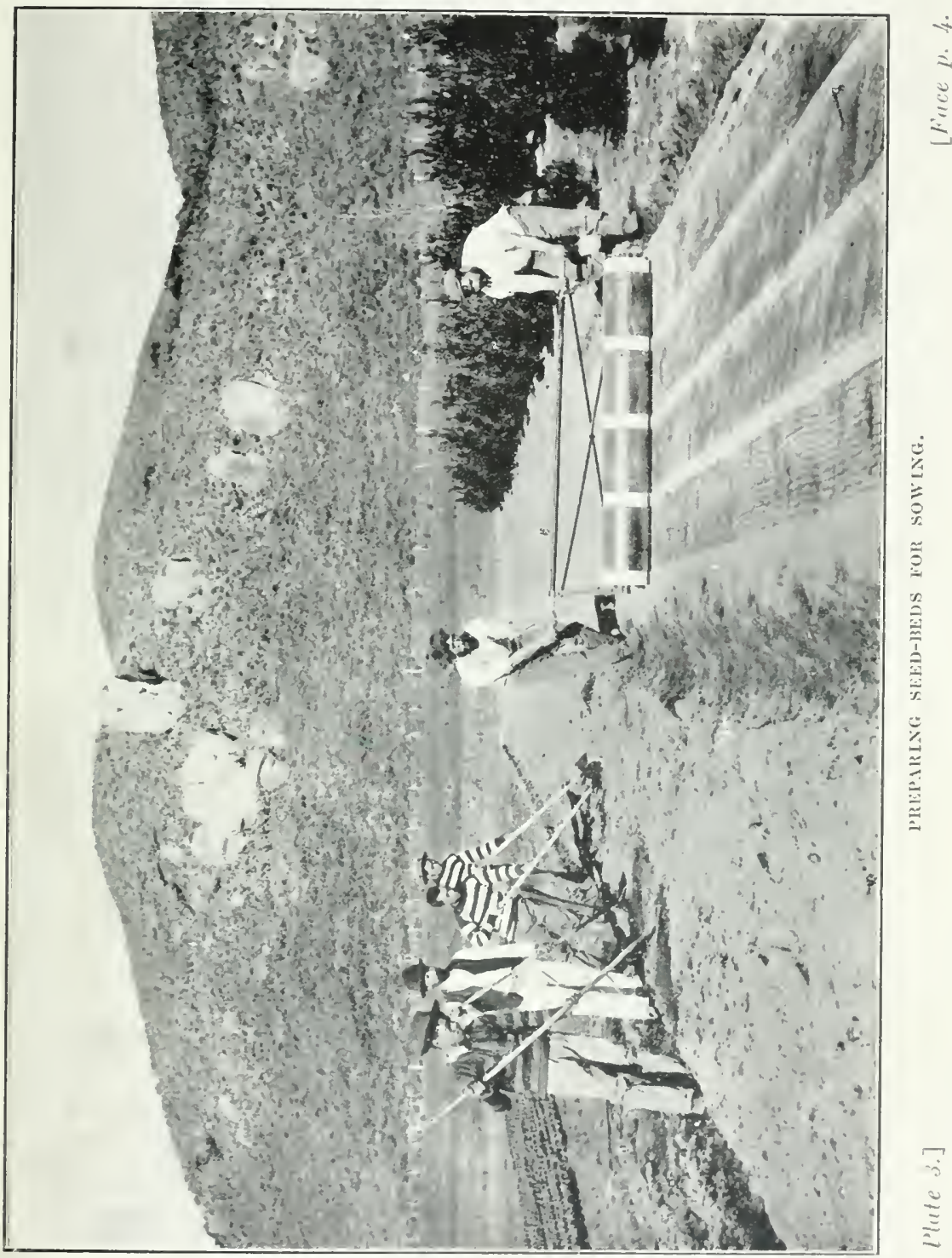



ably seconded by the shepherd, who during the spring months is constantly uot only burning the coarse herbage to obtain a fresh succulent growth for his flocks, but every year his fires encroach further and further into the wooded valleys, and in time leave only isolated patches in some of the damper situations. Cattle and sheep assist in the general destruction by practically clearing all the underscrub within their reach. Rabibits and hares peel and bark the young growth of many young trees and sub-alpine plants, and. when ieed is scarce, eat down the herbage of steep hillsides to such an extent that further growth is arrested; a bare patch occurs on which the sun and wind have full play; gradually the barren area extends, and heavy rains soaking into the open unprotected soil cause a landslip, which is carried down to the lower valleys by successive floods.

Our four principal cities are at present engaged with the question of extending their water-supplies for domestic use and power purposes. Numerous municipal authorities throughout the colony are securing extensive areas for watersheds. The development of water-power was until recently confined to localities close to streams, but recent advances in the application of electricity permit of industries being placed at points distant from the water-power but convenient for transportation and labour. These conditions open up a wide field for the utilisation of streams as a source of power. In various parts of the colony extensive water-power plants are in operation or contemplated, and it is probable that the number of these will be considerably augmented as time goes on. Irrigation also is becoming a recognised feature of successful farming in many parts. Accepting the almost universal testimony that iorests are conservers and regulators of water-supply, the importance of protecting the sources of streams is apparent. The purity of watersupply, the prevention of destructive floods and consequent periods of drought, and the continuous supply of water-power for mechanical purposes are all dependent on the forest covering being maintained as Nature provided it. No country in the world has been more abundantly supplied by Nature than ours, either with more generous forests or more permanent and weil-distributed streams for the many uses of man, and it behoves us to conserve and renew by artificial means these bountiful gifts of Nature for the benefit of future generations. Esthetic and other reasons could be advanced in favour of forest-protection, but probably these would not have so much weight as the more pressing demands of a permanent supply of timber and water. 


\section{CHAPTER II.}

\section{TREE-SEEDS.}

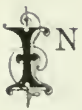

growing trees from seed the source of the seeds is very $1 \mathrm{~m}$ portant, and it is desirable that they be obtained from healthy trees in the prime of life. An unhealthy tree frequently bears a beavy crop of seed, which would possibly be chosen by the professional collector for sale purposes; but the would-be planter should discard such, although the inducement to gather them may be considerable. If possible, seed should be had from trees growing in as severe a climate as that in which they are intended to be sown.

The collecting and storing of tree-seeds rarely, except in the case of nurserymen, receive sufficient attention The fault is generally in gathering them when damp and neglecting to spread them out thinly to dry afterwards. Tree-seeds of many species of deciduous trees can be obtained in any long-settled district of this colony during May and June by merely sweeping them up from under the parent tree. Oak (various species), Sycamore, Chestnut, Walnut, Birch, \&c.. may be collected in this manner, while Alder, Ash, Rowan, Maple, Beech, Locust, Acacia, and all conifers require to be gathered by hand during the months of April, May, and June. Elm-seeds ripen much earlier, usually in December and January.

In regard to most coniferous-tree seeds, it will be found much cheaper to obtain supplies from a reliable firm of seedsmen, as there is considerable difficulty in extracting the seeds from the cones, and if heat is applied there is a danger of the seeds being destroyed in the process. The cones of Pinus insignis can be gathered at any season, and if these are spread out on a sheet during bright sunshine and kept free from damp most of the cones will open sufficiently to release seeds in the space of a few weeks. After the cones are opened, a good plan for extracting the seed is to half fill a sack with cones and beat it thoroughly with an iron bar, turnizg the bag into a new position at every stroke. This also applies to the cones of any species of pine. Seeds of the Cypress family are freely produced in this colony, and these can be collected and removed from their cones much more cheaply than if purchased. A very few days will suffice to extract the seeds from most species if they are spreal out under cover, and the remainder can be beaten out in the same manner as Pinus insignis.

With the Eucalyptus family this difficulty presents itself : Practically all the species ripen their seeds in late spring or early summer, generally too late for sowing the same season, unless the seed-cases can be artificially heated so as to extract their contents within a few weeks. The general practice is to collect Eucalypti-seed about the end of the year, and store it in cotton bags suspended to the ceiling of a dry outhouse until required the following spring, by which time there will be few seed-cases tirat have not cast their contents. 


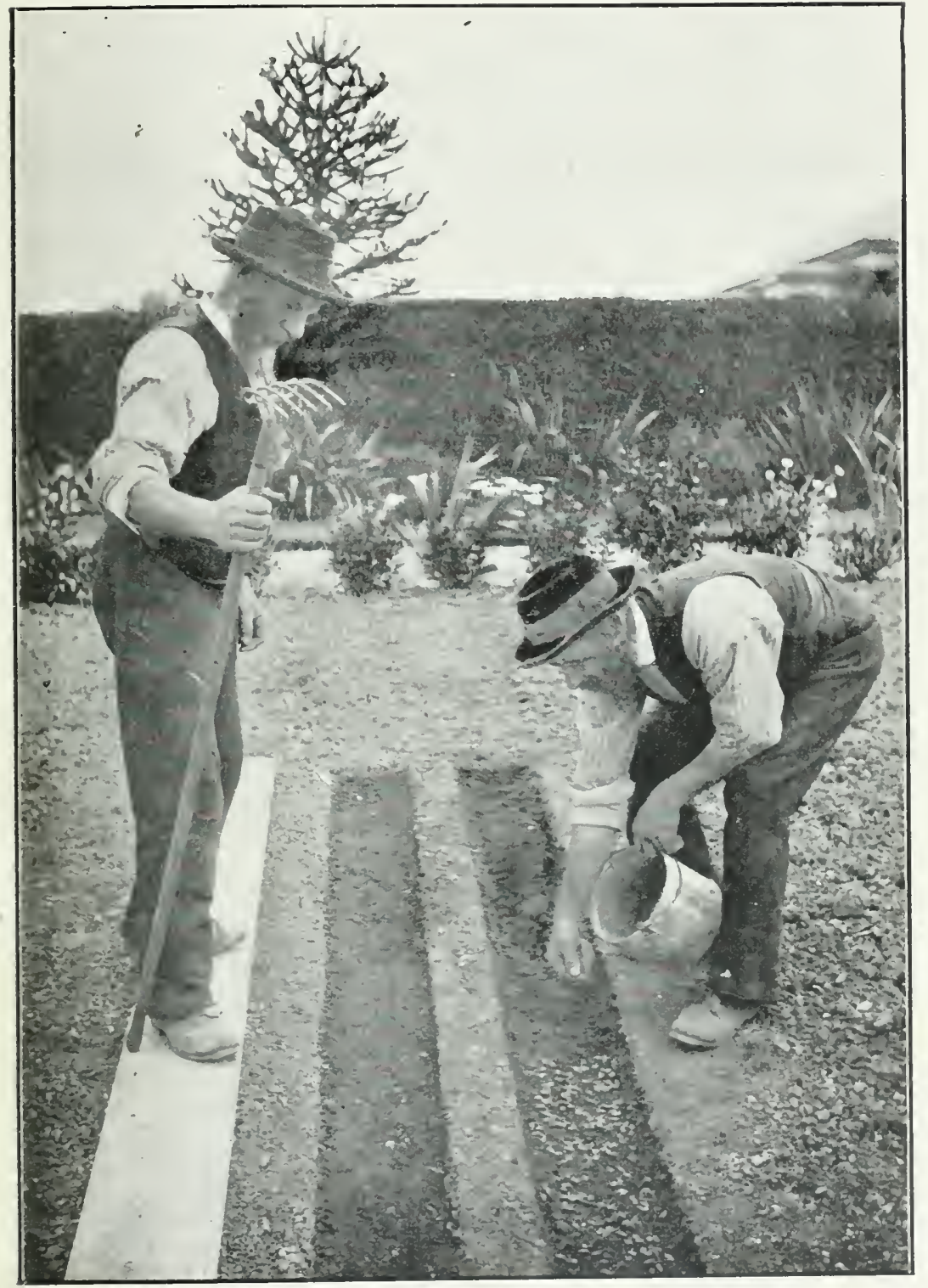

Plate 4.]

PREPARINEG SEED-BEDS WITH VIAXK.

[Fuce p. 6 . 

To enable purchasers to regulate orders for seeds, the following table will show approximately the number of seeds in a bushel or pound, and the number that may under ordinary circumstances and with a fair sample of seed be expected to germinate. It will be noted that a very small proportion of tree-seeds are fertile, especially those imported from Europe and America :-

\section{Broad-Leaved Trees}

Common Name of Tree.

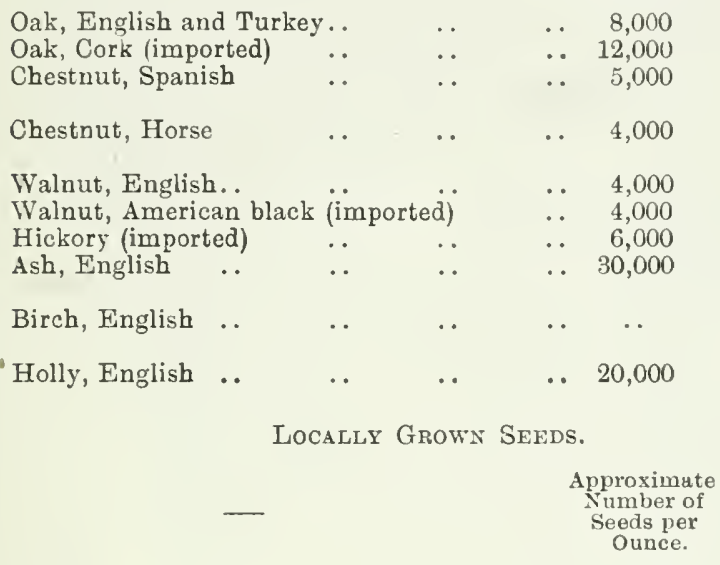

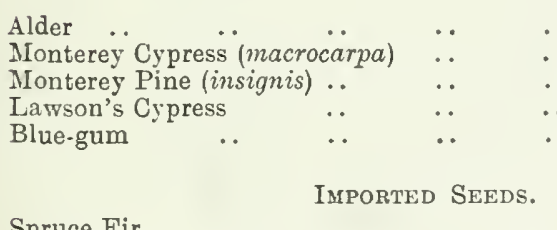

Spruce Fir

Larch ..

Austrian Pine

Corsican Pine

Coulter Pine

Jeffrey Pine

Weymouth Pine

Sugar-pine

Heary Pine

Bentham's Pine.

Black Locust ...

Douglas Fir ..

Hemlock

Menzies' Spruce..

Red Cedar

Piedwood

Silver-fir, according to species

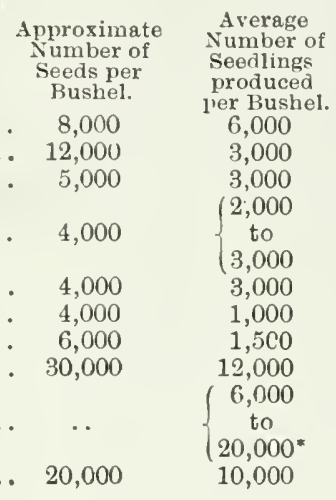

. 3,125

. 2,900

. 1,246

- 8,216

. 23,000

Average

Number of

Seedlings produced from an Ounce

of Seed.

2,000

1,850

950

6,200

9,000

\begin{tabular}{|c|c|c|c|c|}
\hline .. & .. & .. & 4,300 & 3,250 \\
\hline . & .. & .. & 4,250 & 1,100 \\
\hline .. & .. & .. & 1,925 & 1,230 \\
\hline . & . & . & 2,578 & 2,100 \\
\hline .. & . & . & 85 & 53 \\
\hline$\cdots$ & .. & .. & 556 & 340 \\
\hline . & .. & .. & 1,983 & 1,42 \\
\hline & $\cdots$ & .. & 127 & 93 \\
\hline & .. & . & 623 & 497 \\
\hline & .. & .. & 396 & 284 \\
\hline & .. & .. & $1,6 \pm 3$ & 1,210 \\
\hline & -. & .. & 3,116 & 2,870 \\
\hline & $\cdots$ & .. & 11,333 & 8,32 \\
\hline & $\cdots$ & . & 28,300 & 13,000 \\
\hline & $\cdots$ & .. & 1,416 & 1,01 \\
\hline & $\cdots$ & .. & & \\
\hline
\end{tabular}


These figures must be taken as only approximate, although they are compiled from results obtained over several years' trial. One pound of Larch has produced over ten thousand plants on more than one occasion, and the same quantity of Spruce Fir has yielded twenty thousand seedlings.

For such seeds as Oak and Chestnut almost absolute certainty of germination can be reckoned on if they are immersed in water for a few minutes prior to sowing, when all the good seeds will sink and the bad ones will float. Most varieties of seeds can be tested by either cutting them open with a pen-knife or bruising them by pressure. The kernel ought to completely fill the carity of the shell; it should generally be white (except with Ash and Maple, in which case it is bluish). Coniferous seeds when bruised should leave traces of moisture and emit an odour of turpentine if they are of good quality. Another good plan for testing the vitality of coniferous seeds is to put a few on the top of a hot range or oven. If combustion is slow and silent the seeds are useless, but if they spring or turn over and emit a crackling sound it may be safely determined that these possess all the properties essential to germination. There are many kinds of seed-especially those with a hard covering-which it is necessary to steep in water or mix with damp sand previous to sowing. Pinus excelsa, $P$. strobus, and $P$. Lambertiana, and, in fact, all the varieties having five leaves in a bunch should be treated thus. Larch may also be mixed with damp sand for a reek or ten days prior to sowing with beneficial results. All leguminous seeds, such as Kowhai, Laburnum, and Robinia should be soaked in hot water previous to sowing. Place the seed in a vessel of hot water on the fre until boiling-point is reached; then remove from the fire and stir briskly at intervals, leaving the seed to soak for three or four days. Remove the seeds which are floating on the surface of the water and sow these at once, being careful not to allow them to become dry. Continue this process until all the seeds have swollen sufficiently to rise to the surface. Any seeds that do not float within a week may be considered useless. This process is, however, unnecessary if the seeds are sown immediately they are ripe and are not allowed to dry thoroughly. Seed with a fleshy or tough covering - such as the Holly, Rowan. Service Tree, Hawthorn, Juniper, and Ashshould be mixed with damp sand (in about equal proportions) immediately they are gathered, and left in the open until the following season. Frequent turning is necessary to thoroughly rot the pulpy matter. These seeds are generally ripe in June, and if they are "pitted" in sand for ten or twelve months and sown in late autumn germination will take place about September following. 


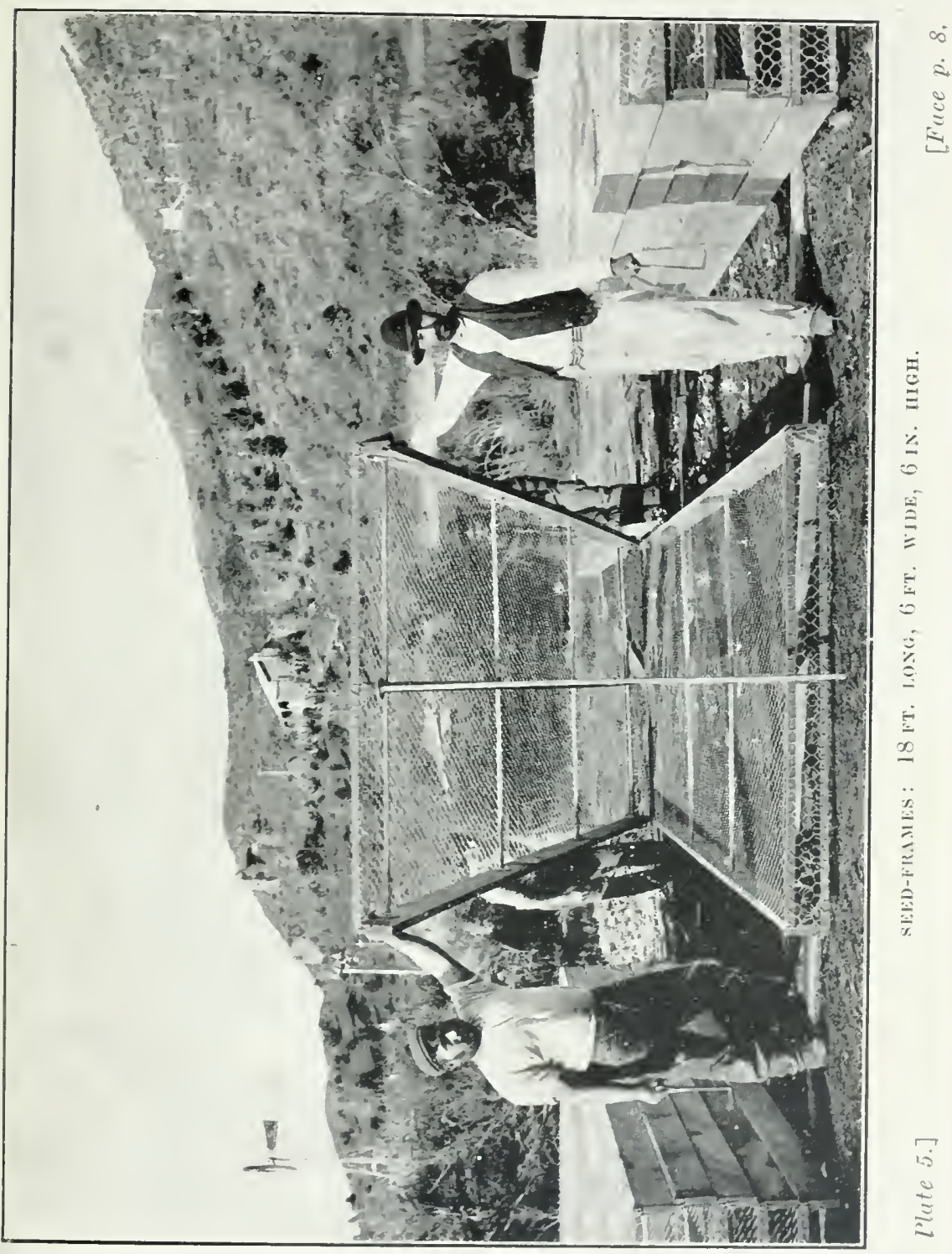





\section{CHAPTER III.}

\section{THE NURSERY.}

Af a nursery. It is seldom that the planter has much choice of locality, but it may be of some assistance if a few essential points are mentioned. Generally speaking, a northern exposure is to be preferred, and for this reason: many so-called tender plants are capable of withstanding several degrees of frost provided they are thawed gradually. If, therefore, the sun has time to make its warmth felt before it strikes directly on seedlings the danger from frost will be greatly reduced. The State nurseries at Tapanui, Starborough, and Rotorua have an approximately northern aspect-at least, they are shaded in winter from the early morning sun by hills of considerable height-and the lifting of the seedlings by frost is practically unknown at these stations. Apart from the question of aspect, the site should be fairly sheltered without being shaded. The shelter must not, however, be such as would prevent a free circulation of air, without which a healthy condition of the soil or plants cannot be maintained. The ground should be sightly on the incline, to aroid an excess of stagnant moisture, but not too much so, as heavy rains will tend to wash out the young seedlings whilst germinating. No site should be chosen steeper than $3 \mathrm{ft}$. of fall in one chain in length. The extent will, of course, be regulated according to the wants of the planter. The soil should be only moderately rich, free, sandy loam, inclining rather to poorness than otherwise. On rich heavy lands young trees will make extremely vigorous growth, combining all the elements of success and prosperity, but if these are transplanted into poor or indifferent soil (as is often the case) the results will be disappointing and unsatisfactory. On the other hand, if trees are raised on soil of medium quality they will not sicken and sulk if they are afterwards transferred to poor land, and should the land of the plantation be better in quality than that in which the trees have been raised so much the better will be the chance of success. Stiff clay soils should be avoided for nursery purposes, especially for growing coniferous irees, which are extremely sensitive to excess of moisture during the first few years of their growth. Amongst professional nurserymen the raising of coniferous trees on stiff clay lands is frequently practised, but with the usual annual result that thousands perish from the disease commonly called "damping off." This "damping off" only occurs while the plants are growing rapidly during the first year. In such a case the seeds start well, and the 
seedlings grow vigorously for a short time, or until a spell of damp weather sets in, when they die off with great rapidity. Too-frequent. watering and too-dense shading also tends to weaken the plants and render them liable to disease. On the other hand, if the seedlings germinate too thinly to cover the ground and protect one another they are apt to become spattered with mud, which has a weakening effect and induces disease. When poor germination takes place it is usual to cover the beds with a thin layer of sand, which not only protects the plants from mud-splashing, but prevents the growth of moss-a deadly enemy to all seedlings. With most species of deciduous trees the nature of the soil is not of so much importance, as they are more vigorous growers than conifers, and are rarely in the seed-beds longer than six or eight months.

The ground intended for seed-beds should be deeply dug (or preferably trenched) during the previous autumn, and allowed to pulverise by the action of frost until spring. Care should be taken not to bring the bottom "spit" up to the surface, but the soil and subsoil should be evenly mixed. In the process of trenching, all roots, stones, and clods should be removed, and nothing left in the ground that will impede either the work of seed-sowing or the subsequent growth of young plants

Drainage is essential to success on all lands of a retentive nature. Most nurserymen prefer to take a crop of potatoes off the land intended for seed-sowing, and this practice is certainly to be recommended when new land is used for the purpose. The vigorous upward growth of young plants and the extent to which they develop fibrous roots depends far more on the fine state of pulverisation to which the soil has been reduced than on its richness. Moreover, on this, too, depends the maintenance of a permanent supply of moisture by capillary attraction. Deep cultivation is justified by the fact that it admits air into the soil, which causes the roots to develop rapidly, and, while permitting the infiltration of water, it lessens the risk from drought. Other advantages of deep cultivation may be mentioned, the chief of which are that stagnant water cannot lie within the reach of plant-roots, a relatively higher temperature is obtained even in the coldest months, the action of frost and extreme heat penetrates to a less depth, while the moisture derived from dew is absorbed more freely and parted with less readily. A month previous to seed-sowing the ground should be made level with a harrow, and the squares and footpaths laid out. After this, and before the beds are made, the whole should be deeply dug over and the soil reduced to the finest possible state of division. The exact time for seed-sowing cannot be laid down with any precision, as so much will depend on the locality, as well as the season experienced. From September in the north to October in the south may be regarded as the most suitable time for coniferous and other small seeds; while deciduous-tree seeds, such as Oak, Sycamore, Chestnut, Walnut, \&c., should be sown as soon as gathered in the autumn. 
1.

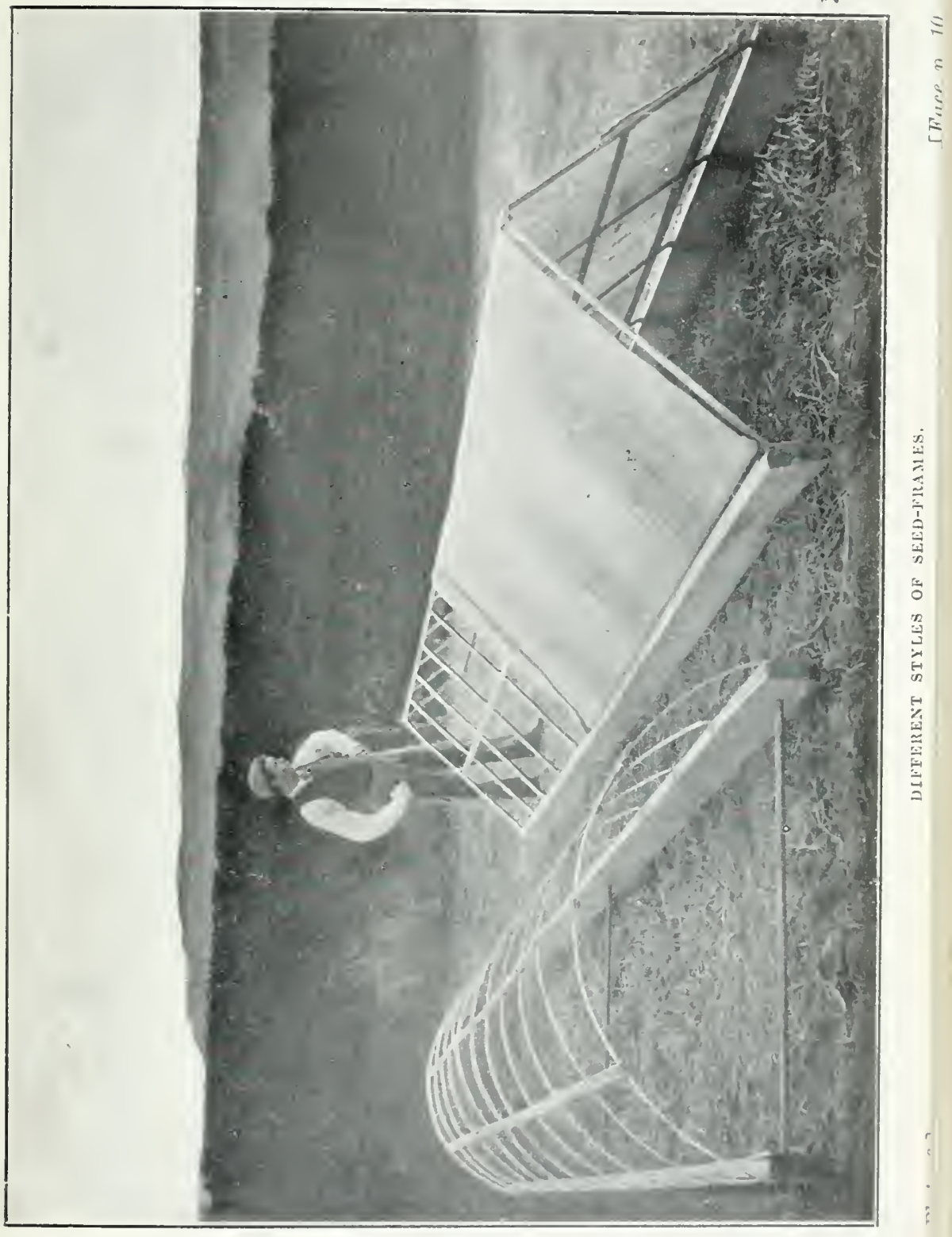



In laying off the seed-beds it is desirable that they run as nearly north and south as possible, so that the sun may shine equally on both sides.

In but few parts of New Zealand can coniferous seedlings be raised withont some protection from the sun, and also from the ravages of birds. On the west coast of the South Island, southern Otago, and Southland, where there is a heavy rainfall, shading can be dispensed with, but on account of small birds wire netting is indispensable. Various devices have been resorted to as seed-bed protections on which to stretch the netting and shading material. Plates 5 and 6 will convey some idea of these structures. These seed-frames are made either $3 \mathrm{ft}$. or $6 \mathrm{ft}$. in width, and $18 \mathrm{ft}$. in length-probably those $3 \mathrm{ft}$. wide will be found the most convenient. They consist of two $18 \mathrm{ft}$. lengths $6 \mathrm{in}$. by $2 \mathrm{in}$., or $6 \mathrm{in}$. by $1 \frac{1}{2} \mathrm{in}$., timber placed on edge, with four or more $\frac{3}{4} \mathrm{in}$. round iron bars tightly driven into the timber at equal distances $2 \mathrm{in}$. from the top edge. Another rather expensive but more satisfactory method of connecting these timbers is to use $\frac{1}{2} \mathrm{in}$. or $\frac{3}{4} \mathrm{in}$. piping, with a flange on both ends, in which three or more holes are drilled for screws or bolts for fixing to the timber. On each end can be nailed a piece of board or two pieces of $1 \frac{1}{2} \mathrm{in}$. by $\frac{1}{4}$ in. angle iron, and the whole covered with wire netting. Where birds are troublesome the netting should be either $\frac{1}{2}$ in. or $\frac{3}{4}$ in. mesh, as, if larger, the birds will get their heads through and pick off the seedlings as they germinate. If shading is used to protect them from the sun, any mesh of netting can be used, as it is merely a support to the scrim or other shading material. For shading, ordinary paperhanger's' scrim (No. 0 or No. 1) will be found the cheapest and nost effective material, as it affords just sufficient protection from the sun, and at the same time permits the rain to percolate to the seed-beds. The price varies from $3 d$. to $4 d$. per yard of $72 \mathrm{in.}$ in width. The scrim should be fixed on to the woodwork on top of the wire netting (which can be stapled on permanently) with $\frac{1}{2}$ in. tacks and pieces of cork, or squares of linoleum, to prevent tearing by heavy winds. When it is necessary to weed the seedlings or hoe the spaces between the beds the frames can be tilted up, either on their side or end, and a strut put in to keep them in position. (See Plate 6.) The material necessary for one of the frames can be purchased for about 10s. or $12 \mathrm{~s}$., and any handy man can easily put them together. In extremely hot localities it is advisable to use seed-frames as illustrated on Plate 6 , as the intense heat tends to cause the plants to wither and "damp off." These frames are merely bows of hoop iron on hips of ordinary standard iron, exactly $6 \mathrm{ft}$. in length, and connected with longitudinal bars of iron or wood to keep them in place. These bows (or hips) should be cut $6 \mathrm{ft}$. long before bending, so that a full width of scrim can be put over the frame and tacked to each side of the woodwork.

In preparing the ground finally for seed-sowing, the whole should be made moderately even and raked smooth by the work- 
man whilst standing on the narrow paths between the beds. Tramping the ground should be avoided, as it will cause uneven sinking. No work should be attempted unless the ground is practically dust-âry : even the slightest moisture which would tend to cause the soil to adhere to the tools is objectionable. If a rainshower comes on this work must at once cease or failure will be the result. It is unnecessary to enter into the question of why the seed-beds should only be worked "dust-dry," but if any one is sceptical and wants to experiment at the cost of his crop of trees let him try seed-sowing on damp ground during showery weather.

The amateur forester may be curious to know why the young seedlings in a nursery are grown in comparatively narrow rows and not covering the whole width of the seed-beds. The reason can best be explained by reference to Plate 9 , where two spades are shown sunk into the ground on either side of a bed of seedlings and practically meeting below. When the autumn growth is complete -say, in April or May - what is technically called "wrenching" is resorted to. The workmen press their spades in to the ground and exert sufficient pressure on the handies to raise up the whole of the seedlings. This cuts or breaks the extremities of the tender roots, and prevents further growth vertically. Within a few weeks after "wrenching" numerous fibres are produced in all directions from the severed roots, and in place of, as formerly, a few straight taproots, there will be a mass of short fibrous tissue. lt would be practically impossible to trausplant young seedlings successfully unless they were previously "wrenched" in the manner stated. The spaces left between the narrow beds are therefore for the purpose of inserting the spade, and also for allowing the workmen to tramp the soil tirm after the operation.

The laymg-out of these beds in a workmanlike manner is frequently a matter of ditticulty, while valuable time is lost in measuring and fixing the necessary lines. The writer has devised and adopted in the State nurseries the roller method of seed-sowing, and it is believed that this is the only country where such a system is in use. Reference to Plates 3 and 7 will serve to illustrate the method of working. In Plates 3 and 7 the darkened portions of the roller are $\frac{3}{4} \mathrm{in}$, diameter larger than the lighter portions, which form a series of depressions $\frac{3}{8} \mathrm{in}$. deeper than the rest of the bed. These depressions are about $12 \mathrm{in}$. in width, and the spaces between them may vary from $4 \mathrm{in}$. to $6 \mathrm{in}$. After the seed-bed has been thoroughly raked even, a line is put down on one side from end to end, as a guide to the edge of the roller. This is merely to ensure the beds being moderately straight, so as to allow of the seed-frame covering only a certain defined width-i.e., to within about an inch beyond the two outside beds. The roller (which is merely a wooden cylinder from $9 \mathrm{in}$. to $12 \mathrm{in}$. in diameter) is then taken over the ground as shown in Plate 7 . When the farther end of the bed is reached the handle is simply reversed, and in front of the roller seed-sowing is commenced, followed up by the roller, which 


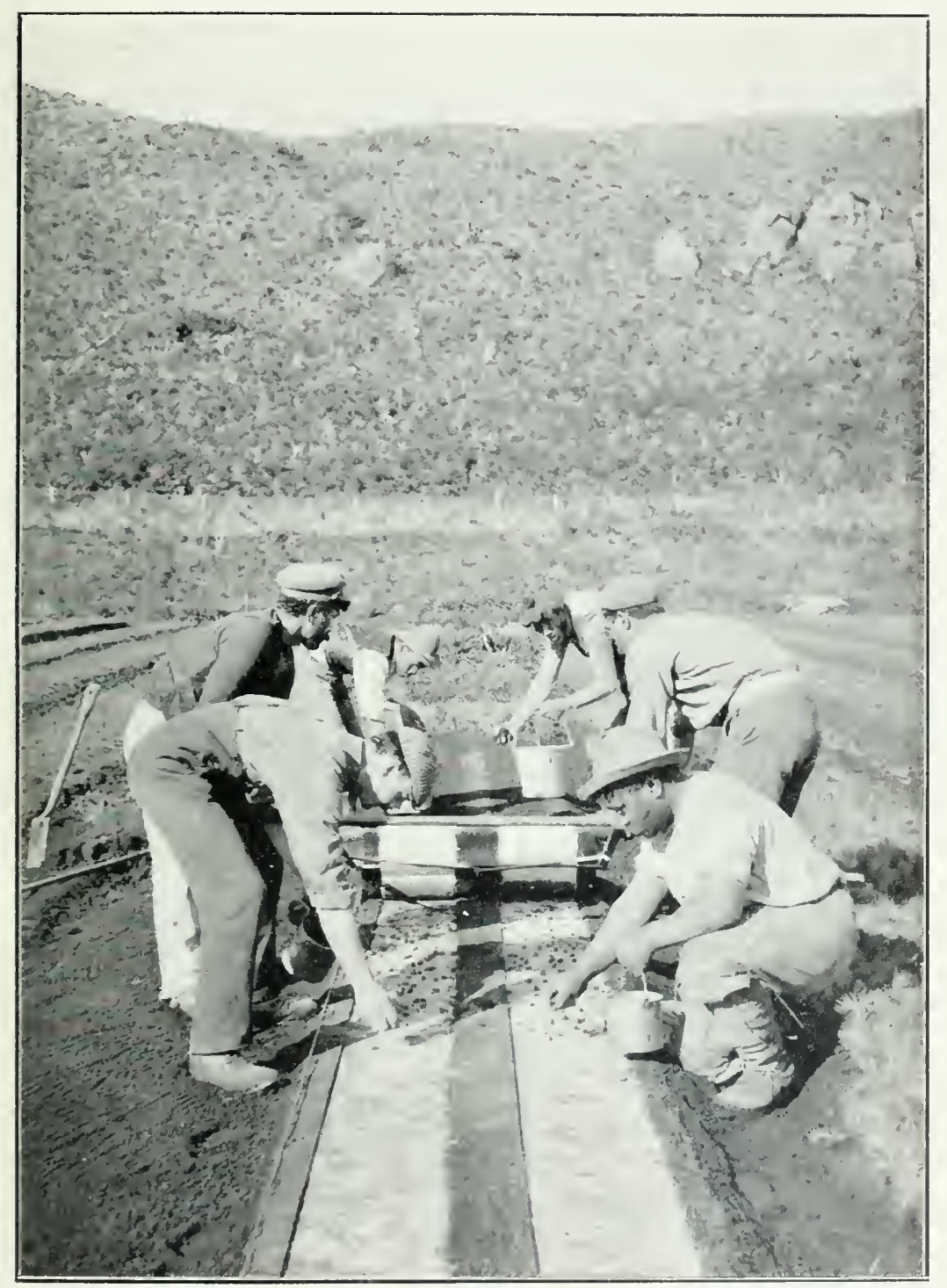

Plite \%.]

TREE-SEED SOWIXG IT ROTOREA NIRSEIR.

[Fuce p. 12. 

presses the seeds into the ground to an even depth, and thus insures their resting on a firm bed-a most essential point, which should be borne in mind when sowing any variety of tree-seeds. Following the roller, two men are engaged covering the seed by hand with soil previously sifted through a $\frac{1}{2}$ in. wire-netting screen. The covering-soil (which should be free of weed-seeds) is comprised of two parts ordinary garden-soil and one part each of sand and burnt earth. This mixture does not "cake" readily, and keeps continually in an open porous state (if used dry), thus enabiing the tender seedings to push their seed-leaves through the ground with facility. When the covering is completed the seed-frames are placed in position and covered with scrim as before described. It is necessary to sink the wooden sides of the seed-frames into the ground fully an inch or more, otherwise during strong winds there will be a continual draught blowing across the seed-bed. If the frame be merely put in its place it will leave sufficient impression to enable a slight hollow to be thrown out by the spade, and the frame can afterwards be replaced to its proper depth. Should the seed sown be previously soaked, or mixed with damp sand, it wili be necessary to keep the beds moist until germination takes place. This is best performed with a watering-can with a fine rose, or with a hose. Care should be taken not to allow an excess of water at one time, in case the soil should be washed off the seeds. It is a good plan to make two or more slight applications rather than a single heavy one, and it will be found that the scrim shading allows the water to percolate much more evenly than by direct application.

There are very fow seeds which cannot be raised successfully by following the methods above described-even the finest eucalyptus-seed, which is so minute that many nundreas would lie on the surface of a shilling. In dealing with these minute seeds extreme care is necessary to prevent deep sowing. Much more care is also necessary in preparing the seed-beds, which should receive an application of sifted soil prior to the formation of the beds by the roller. Practically no covering need be applied to some of the very small eucalyptus-seed and English birch. The mere passing of the roller over the beds to ensure firm contact with the soil will generally be sufficient. Sometimes in very windy localities it may be advisable to dust on (by hand) just sufficient soil to screen the seeds from view. Perhaps there are more failures attributable to too-deep covering of seeds than to any other cause. In general, the more thinly seeds are covered (consistent with their receiving a sufficient supply of moisture) the better their growth, but as a rule all seeds are sown unnecessarily deep. In the majority of cases a safe guide is to cover seed to a depth of about double its diameter, which in the case of some of the eucalypti and birch means practically nil.

The roller system of seed-sowing is equally applicable to the more easily grown deciduous trees, but as these are (or should be) 
sown in early winter they will not require the protection of seedframes. For those who wish to raise only a few thousand seedlings annually the cost of a properly made roller would be an expensive item. Practically the same result can be obtained by using one or more planks $18 \mathrm{ft}$. long, $8 \mathrm{in}$. wide, and $1 \frac{1}{2} \mathrm{in}$. or $2 \mathrm{in}$. thick. (See Plate 4.) When the seed-bed has been thoroughly prepared put a plank down 2 in. from one side and walk along it once or twice, or beat it here and there with a heavy rammer. This will leave sufficient depressions and defined lines in which to sow the seeds. Repeat the operation twice, but the second and third times leave $4 \mathrm{in}$. between the depressions. This will give three beds, each of $8 \mathrm{in}$. in width, two blanks for inserting the spade when "wrenching," and 2 in. of space next each side of the frames-in all, 36 in. wide. When the seeds are sown replace the plank carefully over the bed, and tramp or beat as before, which operation will firm the ground and ensure the seeds having perfect contact with the soil.

It is a very difficult matter to explain exactly how thickly treeseeds should be sown. As previously mentioned, a large proportion of these are usually bad, and it is necessary, therefore, to sow them very closely together, so that the seedlings will cover the ground and shelter one another during the winter. Probably the best method of illustrating what is actually the correct thickness for sowing is to take a sieve of a size that will just allow four seeds of the variety being dealt with to pass through its meshes easily. Lay the sieve on the ground, and imagine that for each square seen a single seed must be sown. Comparatively small seeds, such as Spruce Fir, Larch, Menzies' Spruce, and Alder, may be safely sown by using a $\frac{1}{4}$ in.-mesh sieve, which size will just allow four seeds to go through together. This will be at the rate of sixteen seeds to every square inch if one seed is sown in the centre of each square, and, as more than 40 per cent. of germination is improbable, this will allow ample space for the seedlings to develop until fit for transplanting. The same principle will apply to all other seeds dealt with up to the size of walnuts, four of which will pass through a $2 \mathrm{in}$. sieve, which means that each seed requires 4 square inches of space. For Abies Douglasii and similar-sized seeds a sieve of $\frac{3}{8}$ in. size will be found suitable, and for seeds of Austrian and other pines a $\frac{1}{2} \mathrm{in}$. sieve should be used. It is not meant that sieves should be actually used to distribute the seeds evenly, but the appearance of the squares will convey an approximate idea of the required thickness the seeds should be sown.

The raising of small lots of costly seeds can be successfully accomplished by sowing them in shallow boxes, whisky, brandy, or wine cases being the most convenient for the purpose. The lid should be removed, and several holes made in the bottom with an auger to allow of surplus water escaping. A layer of coarse gravel about 2 in. deep is then placed in the bottom and covered with sphagnum moss or decayed turf to prevent the fine soil from being washed down amongst the drainage. The box is then filled up to 


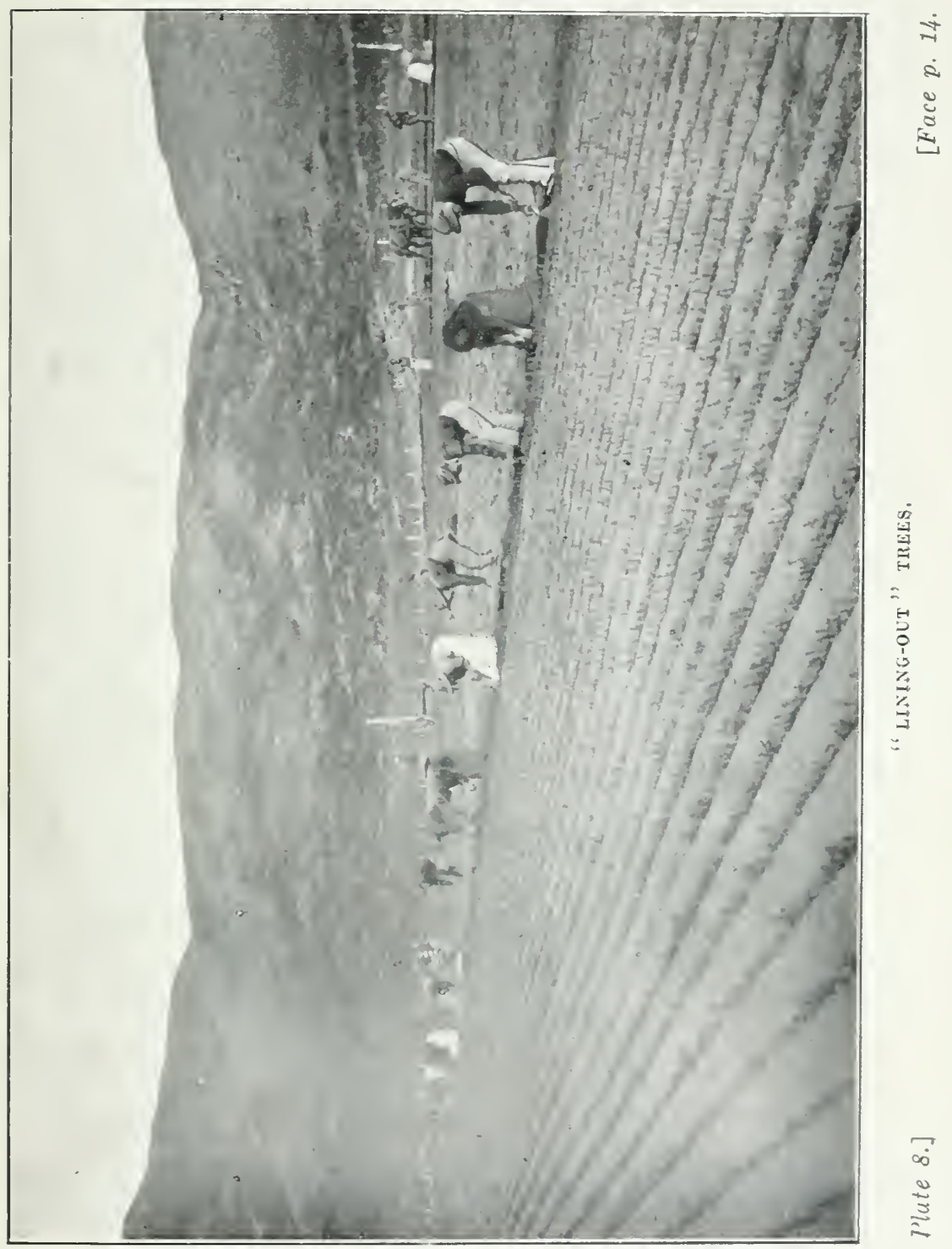



within an inch of the top with ary sifted soil, and well firmed. In sowing the seeds, mark off equal spaces-say, 2 in. apart-on each sicie of the box, and, with a portion of the lid between these, mark a series of depressions to a depth depending on the size of the seed dealt with. In these depressious sow the seeds and cover them to the surface-level. If the seeds are minute great care is necessary to prevent them being washed out whilst watering, and, to obviate this, the box should be sunk into water about two-thirds its depth, and allowed to soak for an hour or so, when the whole contents will be thoroughly saturated. Repeat this operation when the soil becomes ary, and keep the box in a sheltered and partially shaded position until the young seedlings are ready for their first transplanting. Where fowls or small birds are troublesome a piece of fine-meshed wire netting stretched orer the top of the box will prevent damage.

\section{CHAPTER IV.}

\section{TRANSPLANTING YOUNG TREES.} fHE taking-up and storing of the seedlings previous to trans-
plantation requires the utmost care, especially in regard to their tender roots, which should be carefully protected from the sun and from drying winds. The best tool for lifting seedlings is a stout five-or six-pronged potato-fork. This should be inserted a few inches from the outside line of seedlings and thrust to its full depth in a slanting direction, so that when the opposite side is similarly treated the points of the prongs will practically meet in the centre of the seed-beds. It will be found more convenient and the work will be more easily done if two hands are employed during the process of raising. The seedlings should now be carefully lifted by hand, placed in shallow boxes, and brought indoors to be separated, sized, counted, and the extreme points of their long roots removed with a pair of sheep-shears. A mixture of equal parts of cow-manure and garden-soil should then be prepared in a tub or other shallow vessel and sufficient water added to make a fairly fluid paste. Then take a small handful of seedlings and dip their roots into this puddle in such a way that all are equally coated over with a fine layer of mud. The plants should now be removed to a vacant corner of the nursery, and, a trench having been opened with the spade, they should be laid thinly against its sloping side and their roots at once covered with fine soil. From these trenches they can be removed as required for transplanting.

It will be found that in every crop of seedlings the size of the plants will vary considerably, and it is recommended that the plants should be divided into two sizes-the larger ones for "lining out" 
in nursery rows and the smaller ones for "lining in" closely. If the whole crop is lined out, many of the smaller plants will not be sufficiently advanced to admit of their being transferred to the plantation with the larger size, and these will require another season in the nursery to bring them up to the required height. It is usual, therefore, to keep all the small-sized plants separate and line them in closely until the next planting season, when they will have attained sufficient growth to be lined out with the stronger seedlings of the following year's crop.

The object of transplantation is to encourage the formation of fibrous rootlets, without which most species of trees cannot be transferred to the plantation with any degree of success.

Whether transplanting should take place during the autumn or spring, this will depend entirely upon the local conditions. Where the thermometer falls to $8^{\circ}$ or $10^{\circ}$ below freezing-point $\left(24^{\circ}\right.$ or $22^{\circ}$ Fahr.) transplanting should be deferred until spring, otherwise the expansion and contraction of the soil by frost will throw out the young plants. Vigorous-growing deciduous trees, such as Oak, Ash, Elm, Poplar, Chestnut, Walnut, \&c., can, however, be transplanted during the autumn, provided they are at least 12 in. in height and the locality is not liable to extreme frosts. Undoubtedly autumn transplanting is preferable to spring if the conditions are favourable, as the alternation of frost and rain which characterizes the season at the period of cessation of growth produces complete contact between roots and soil. Where large numbers of trees are being dealt with frequent interruption may be looked for on account of the state of the weather, and it may be found necessary to divide the work between the two seasons, the larger and more vigorous seedlings being transplanted during the autumn, the smaller and less sturdy seedlings during the spring.

The land intended for transplants should be thoroughly prepared in the same manner as recommended for seed-beds, as deep cultivation and drainage are essential to the future success of the plants. It should be rough-ridged for some months previous to use in order to expose it to atmospheric influences, more especially when it is intended to plant during the spring.

The following is the method adopted in transplanting: A trench is opened up at one side of the ground with the spade and the material removed to the opposite side where it is assumed the planting will finish, so that in the process of digging there will be sufficient soil to refill the trench when the final row of trees is completed. Two or more "spits" of soil are then dug into the trench until a width of $15 \mathrm{in}$. is reached, and the whole made even by manure-drags or wide-toothed rakes. A garden-line or thin wire (No. 14 gauge) is then stretched from end to end at $10 \mathrm{in}$. from the starting-point and $5 \mathrm{in}$. from the edge of the newly dug ground. Each planter should be provided with a small bag suspended in front by a shoulder-strap in which to carry a supply of plants. To make the necessary opening for the reception of each plant a brick- 


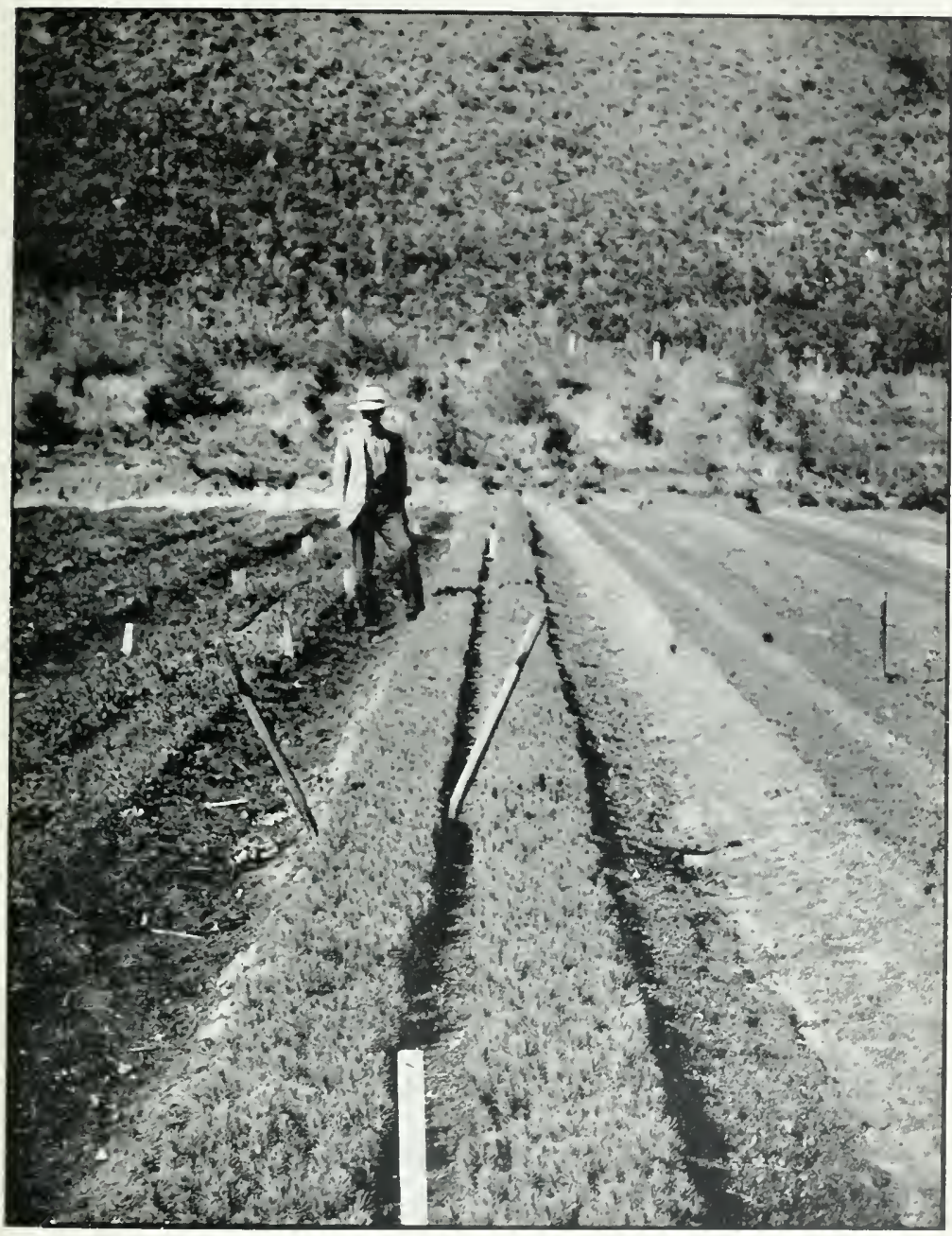

ALEPPO-PINE (PIES HALFENSIS) SEEDIANGS, SHOWIXG IOSITION OF

Plate ?.] SPADES IX " WREXICHXG,

$[$ [ine $P, 16$. 

layer's trowel is thrust into the ground on the side of the line whilst the planter is standing in the trench. The handle of the trowel is then drawn forward sufficiently far to make the required space for the plant, which is then inserted against the vertical side and close to the line. The trowel is then withdrawn, and a gentle pressure of the foot will close up and replace the soil in contact with the plant. Plate 10 shows this work in progress. The distance from plant to plant is regulated by the size of seedlings dealt with and the time it is intended they should remain in the nurserylines. From 4 in. to 6 in. berween the plants and from 10 in. to 12 in. between the rows will be found suitable for most seedlingtrees. When a line of plants is completed another $10 \mathrm{in}$. of soil should be dug ap against the line and the work continued as above described. When the lines are two or more chains in length it will be found advantageous to use the plough for turning over the soil against the plants, and in such a case two lines should be kept going at once, so that while the planters are engaged in planting one line the plough is turning over one or more furrows against the other line. If the ground is in good order there will be very little more time occupied in rough levelling after the plough than if the same work had been done with a spade.

"Lining in" is performed in exactly the same manner as lining out, except that the plants (being smaller) are placed almost touching each other in the lines, and the spaces between the lines are usually closer-say, 4 in. to 6 in. (See Plate 21.)

Transplanting should not be carried on while frost is in the ground, or during heavy winds, or while the soil is so moist that it adheres to the tools. After the first shower following transplanting the whole of the "break" of transplants should be hoed with a Dutch hoe, thus settling the soil around the plants and preventing "caking." This operation should be frequently performed in bright dry weather throughout the growing season, and at the same time all weeds which cannot be reached by the hoe must be removed by hand. The Planet Junior hoes are excellent tools for this work if they are fitted up to straddle the rows, with two or three narrow teeth on either side of the row. These teeth leave the land in small ridges, a condition which is preferable to the smooth surface left by the Dutch hoe. In addition to doing good work, these tools are immense labour-savers when properly understood and worked with judgment. A man at the handles and a lad in front pulling by a cord and crossbar will do more and better work than six men with hand-hoes. If the lad walks with a foot on each side of the plants and the man follows in the next row between the plants there will be no footmarks left to disfigure the work or consolidate the soil after being loosened by the hoe-teeth.

Very few species of conifers will grow to sufficient size during the first season for transplanting into nursery-lines, although, if the seeds are sown early and a favourable season follows, some individual plants may reach the required standard-say, 3 in. to $4 \mathrm{in}$. in 
height. These plants should be carefully taken out from amongst their smaller neighbours about a month after wrenching, and "heeled-in" in readiness for lining out. Firs, Spruce, and most species of Pines will require to stand until the second season before being transplanted. The following trees, being comparatively fast growers, may be expected to attain the required height for transplantation during the first season, or from six to seven months from date of seed-sowing: Pinus Austriaca, P. Benthamiana, P. radiata, $P$. Canariensis, $P$. halepensis, $P$. Conlterii, Sequoia sempervirens, Eucalypti, Oaks, Ash, Beech, Chestnuts, Maples, Catalpa, and probably one-half of Larch, as the growth of a bed of this tree may vary in height from $\frac{1}{2} \mathrm{in}$. to 6 in.

Considerable care will require to be exercised in dealing with poor-rooting trees, such as the Corsican and Maritime Pines and $P$. Sabiniana, as these species develop a strong tap-root with very few lateral fibres. The Corsican Pine-which is probably the fastest-growing and most valuable of all the pines to plant as a timber-producer for quick returns-is exceedingly difficult to transplant successfully. As the result of a good many years' practical experience in dealing with this tree in large numbers, the writer is convinced that failure is principally due to planting whilst the ground is cold and wet. An essential condition for success is to transplant this species before growth is actually completed in the autumn, or late in spring just as the new growth commences. One or even two severe wrenchings, and special care in lifting and planting, will also be conducive to comparative success.

As the production of a heavy crop of vigorous seedlings must necessarily lessen the productiveness of the soil, and since a sufficient degree of fertility cannot be maintained unless the mineral constituents are restored, manuring becomes imperative. A good heavy coat of farmyard manure should be applied to the seed-bed land immediately after a crop has been removed. At crop of clover, tares, or other leguminous plants should then be sown, to assist in decomposing the crude matter. When the crop reaches about a foot in height the whole should be dug in deeply, and the ground left in as rough a state as possible during the following autumn and winter, by the end of which time it will again be in excellent condition for raising another crop of seedlings.

\section{Lifting Nursery-grown Trees.}

In lifting trees from nursery-lines in readiness for permanent planting considerable care is necessary to prevent mutilation of the roots. A trench should be opened as near as possible to the outside row of trees without disturbing the roots. Three hands are necessary to do this work successfully and quickly, so that the roots shall be exposed to the air for as short a time as possible. Two men insert their spades vertically behind each tree, while the third grasps the stem and directs the spadesmen where and when to exert pressure. The trees can be kept under the arm until about 


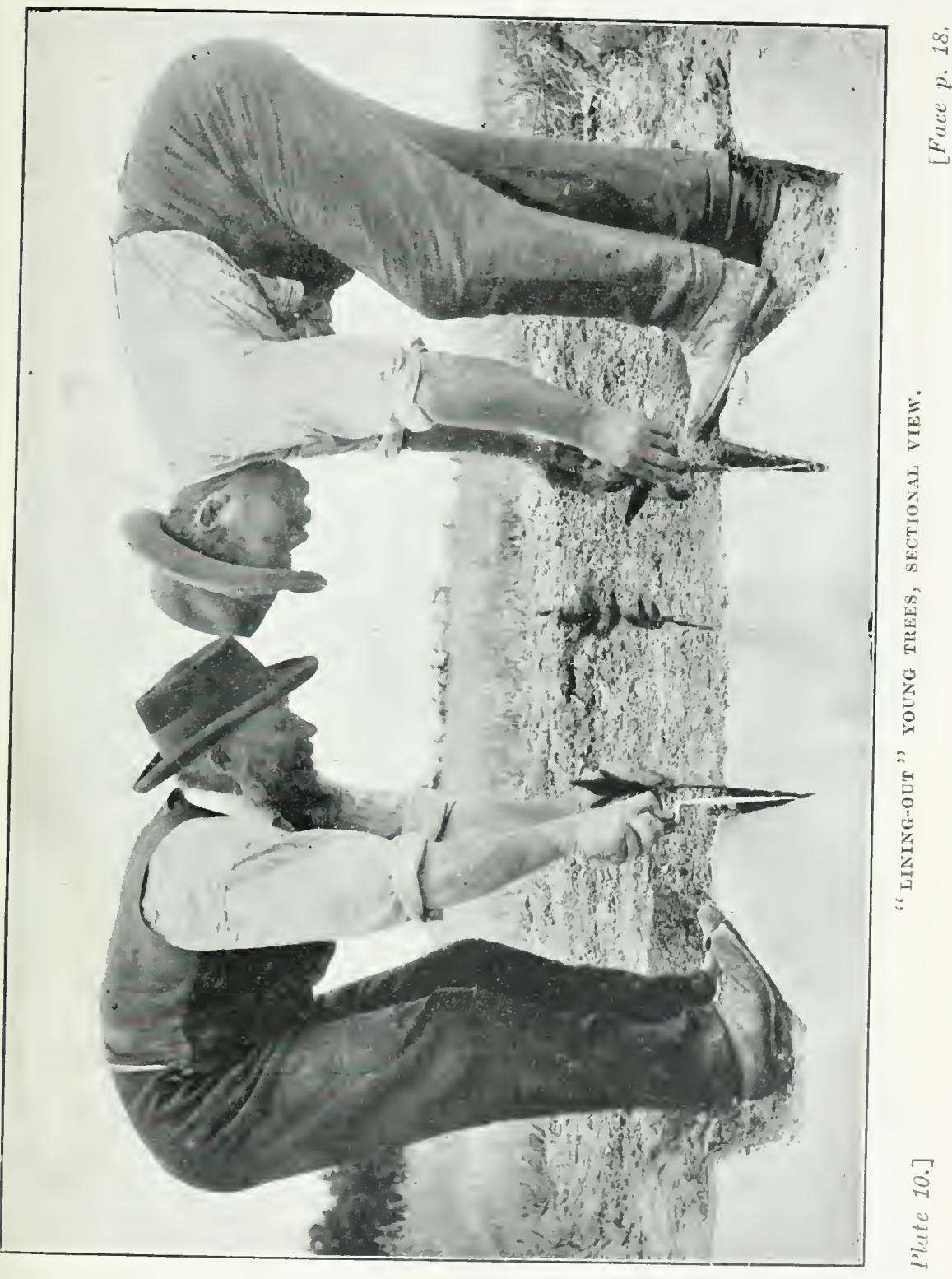



fifty are lifted, when they should be "sleughed" or "heeled-in" until the whole "break" is dealt with. The trees should then be removed under cover, and sized. Any long straggling or bruised roots should be cut off clean, and the whole then puddled and heeled-in or despatched to the plantations. Small-sized trees should be kept separate for lining out for another season.

When packing trees for transport they should be tied in bundles of fifty, and packed into the vehicle with the roots towards the centre, in order to keep them moist. Arriving at the plantation (where trenches should be in readiness for their reception) they must be carefully heeled-in, and well watered if the soil is dry. Should they require to remain for any length of time in the trenches before being permanently planted, the bundles should be loosened and the trees spread out thinly against one side of the trench.

\section{Time to Plant.}

Generally, the best seasons for planting are autumn and early spring. Much will depend, however, on the nature of the soil and the situation. Land that remains wet throughout the winter, which would be apt to throw out the plants by swelling with frost, can only be dealt with in spring. Light lands which are liable to be parched by the heat of summer should, of course, be planted from the fall of the leaf on towards midwinter. Everything, however, depends on the weather and the forwardness of the season in different years. The magnitude of intended operations may make it necessary to begin earlier and continue later than otherwise might have been done. On most of the Government plantations tree-planting is in operation from Nay till October, and, except amongst certain species, there is no apparent difference discernible during the following summer to enable it to be decided whether autumn, winter, or spring planting succeeded best. When such large numbers of trees are dealt with it would be impossible to complete the work at any particular season unless a very large number of hands were employed, which is impracticable, owing to the scarcity of labour in country districts available for a short season only, and undesirable, as it would necessitate the employment of men who have not the necessary knowledge of the work. 


\section{CHAPTER V.}

\section{TREE-PLANTING IN OPERATION.}

Preparation of the Land.

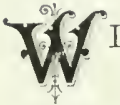

ITH regard to this work much difference of opinion exists. Many assert that thorough previous cultivation is imperative for successful results, while others maintain that such an expensive procedure does not compensate for the increased outlay. Where tolerably level ploughable land is being dealt with (especially in dry situations) it is a good plan to plough and crop the proposed plantation with turnips for one or two seasons prior to planting, as the soil in pits opened on the bare turf shrinks to such an extent that the trees frequently perish through extreme drought, or become stunted or thrown out of the ground in winter through excessive moisture and subsequent freezing, owing to the pits being dug to a lower level than the surrounding soil. On steep, broken lands, however, where cultivation is impossible no previous preparation of the soil is necessary for tree-planting; indeed, such work is out of the question where large areas are being dealt with, owing to financial considerations. The cultivation of land to the depth of $9 \mathrm{in}$. or $10 \mathrm{in}$. can only be of temporary assistance during the first year or two, as tree-roots penetrate too deeply to be permanently benefited by the preparation of the surface-soil.

Draining, however, is essential to success, and all springs and moist places should be tapped and prevented from soaking into and spreading over lower lands. The depth to which these should be opened will aitogether depend on the nature of the subsoil. They should be at least $3 \mathrm{ft}$. deep, and double the width at the top compared with the bottom, so as to give a good batter to the sides and prevent slips from falling in and obstructing the water-flow. It is an easy matter, when the tree-pits are opened, to determine whether land intended for plantation purposes requires draining or not. Should water stand in the pits for more than two or three days after rain has ceased, then the land must be drained if success is to be looked for. The distance apart that it is necessary to open clrains will also depend on the nature of the soil. In laying out drains it should be the ain of the planter to construct them diagonally across a slope rather than parallel with it, as steep gradients will tend to wash away valuable soil, as well as cause erosion and subsequent biocking of the lower levels by débris. Where drains cross fence-lines, swing gates constructed of light iron rods set vertically to the flow of water should be provided. 


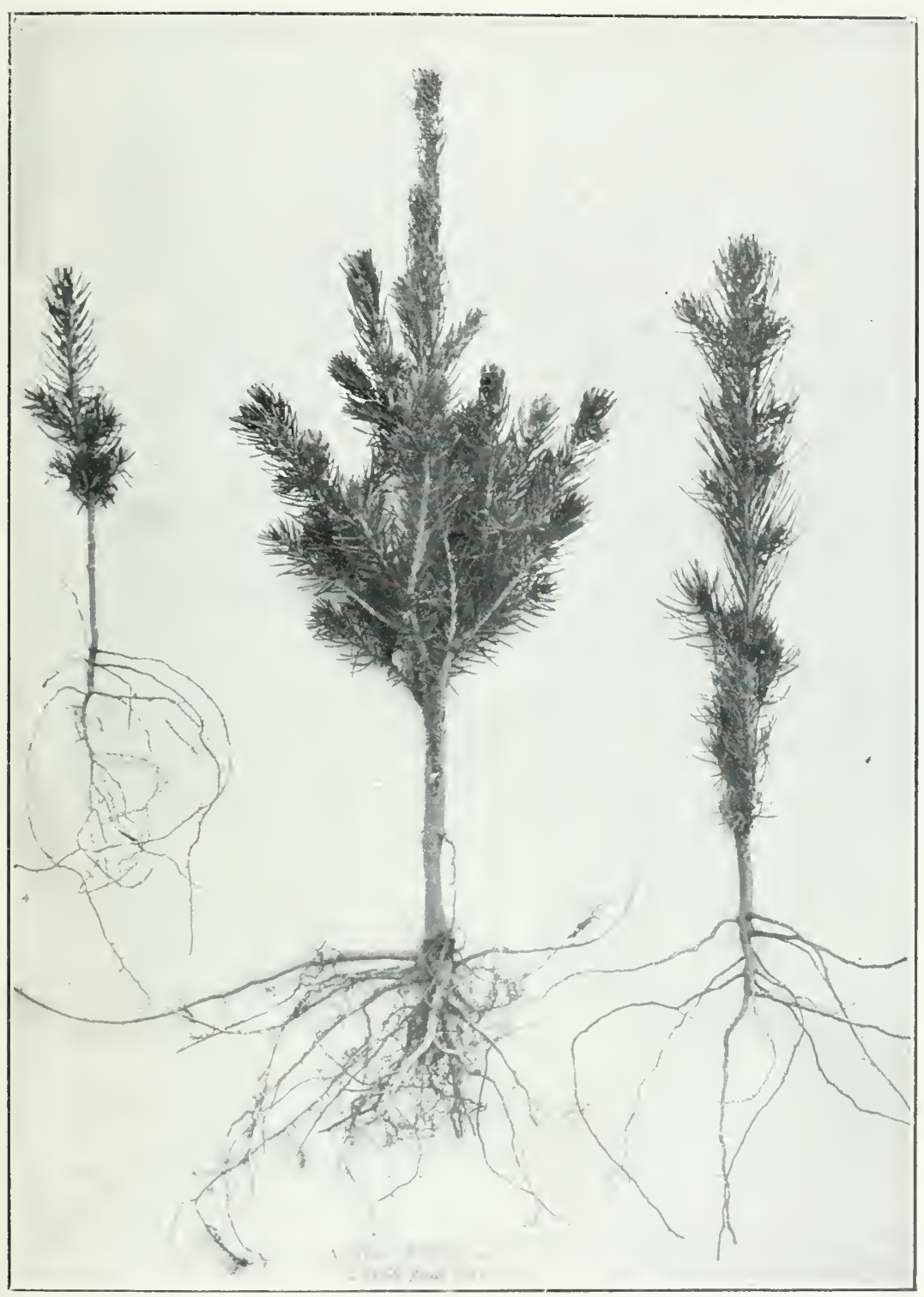

SPRICE FIR (PICEA EXCELSA), ONE, TWO, ANI) TIIREE YEARS OLI).

Plate 11.]

FFace p. 20. 

these are hung to swing there will be less risk of choking than if tixed rigidly.

A most necessary provision in all plantations is the construction of roads and pack-tracks, in order to give easy access to all portions of the area, both at the time of planting and later on for the removal of thinnings and the mature crop. Main roads should be at least $12 \mathrm{ft}$. in width, formed in the centre of one-chain-wide fire-belts-another indispensable provision. About $6 \mathrm{ft}$. or $8 \mathrm{ft}$. will be ample width to allow for pack or bridle tracks for the purposes of inspection and hauling out thinnings by sledge. The location of fire-belts, roads, and tracks should necessarily be determined before planting is commenced. On level ground parallel roads are practicable, but on broken, hilly country the natural conformation must be considered in order to obtain easy gradients. It will be found that fire-belts (with a $12 \mathrm{ft}$. road in the centre) are most effective if located on leading ridges, thus dividing one portion of the area from another, and so lessening the risk of tire spreading over the whole area.

Where scrub, flax, and other coarse herbage exists, cutting, clearing, and burning will be necessary before pitting can be proceeded with. On tussock or fern land, however, burning-off should be deferred until just prior to planting, as if this work is done in the autumn or early winter there will result a strong growth during the ensuing spring, which will require keeping down so as to prevent the smothering of young trees. If, however, burning is done just as the fern or grass is making young growth in spring it will receive a much greater check, and the trees will keep the lead. On heavy, moist lands burning may be impossible, and the reap-hook will be required to prevent too strong a growth of herbage. It is not advisable to keep the ground actually bare of all growth, as the presence of some slight covering affords shelter and conserves moisture, to the benefit of the growing plants.

In regard to fencing, little need be said, as most farmers will know considerably more about such matters than the writer. Needless to say, stock should be kept out of all planted areas, otherwise the branches on the outside edges of the plantation (which should be carefully preserved) will be eaten down, and every wind will blow through the plantation like a funnel. The trampling of forest lands by stock during wet weather cakes the surface and prevents the rains from penetrating in to the soil, thus wasting muchneeded moisture. Further, many trees have their roots practically on the surface, and irreparable damage will be cansed to these by the hoofs of animals.

The seasons best adapted for tree-planting have been mentioned in a previous chapter. When autumn planting is decided on, it should be borne in mind that with many deciduous trees we cannot wait for the fall of the leaf as an indicarion that growth is complete and that planting should be commenced. With the oak, for instance (which is very late in losing its leaves in the autumn), 
planting may proceed when the branches have ceased to grow, the buds for the following season have formed, and the wood has a firm, ripened appearance. Ash, Sycamore, Elm, Birch, and most deciduous trees can also be planted just when the change of colour from green to yellow or brown appears, which may be a month or more before the leaf actually falls.

There are three methods usually adopted in the planting of forest-trees - notching, grubber-pits, and ordinary pitting. The first-mentioned system is largely adopted in Europe on thin, heathy lands, but is only applicable with very small plants and where the nature of the ground is suitable.

There is a considerable advantage gained with regard to cost of planting by the notch system, but many more failures are probable than by either grubber or ordinary pits. Planting by this system is usually performed by a man and a boy. The man makes two deep cuts in the turf, crossing at right angles where the plant is to be put; he then inserts his spade across one of the ends of the cross formed and prizes the handle downwards, which causes the cross to open. The boy now inserts a plant to the proper depth, the spade is withdrawn and the turf closes up around the plant, and a firm trampling completes the operation. This method is usually employed in planting Spruce on thin, moist lands where ordinary pitting is impracticable.

Pitting with the grubber-pick (which is an ordinary mattock with a pick on the reverse end instead of a short axe) is done by removing a thin layer of turf and loosening up the ground to the full depth of the pick. This system is applicable to all steep, rocky, or gravelly lands where ordinary pitting would be impossible. These pits usually cost $£ 1$ per thousand. Planting is done with a rabbiter's hoe by driving it into the loosened soil to full depth and then drawing it forward sufficiently to make room for the plant, which is inserted behind the hoe; the hoe is withdrawn, and a good firm tramping of the soil completes the work. This method is, of course, only applicable when dealing with plants whose roots are not longer than the blade of the hoe. Larch and pines can be planted very cheaply and at the same time satisfactorily by this system.

Ordinary pits are made with Black's No. 2 or No. 3 spades, which make a hole nearly $8 \mathrm{in}$. square and $10 \mathrm{in}$. deep. The shape of these will be seen on reference to Plate 15 . It will be observed that the tree is placed hard against the upright wall of the pit, and not spread out, as in the old system recommended by such writers on forestry as Grigor, Brown, and others, who were most particular in pointing out that a tree should be set in the centre of a pit or hole and have its roots well spread. The effect of rain and wind on a tree-planted by this system can be seen in Plate 16 .

Plants lifted with a ball of soil must necessarily be placed in the centre of a hole, but all trees with naked roots should be planted hard against the solid ground, as shown in Plate 15, and there will be much less risk of failure than under the old system, whereby a 

tree was constantly blown about from one side to the other in loose soil. One important point to be remembered in digging pits is to open them with the upright or back wall away from or opposite to the prevailing wind, so that the trees will have solid ground to support them until root-growth takes place and maintains them in an erect position. Another advantage in planting in the manner recommended may be pointed out-viz., that the trees will root much more freely on the side on which support is most needed, owing to the loose open soil being on the windward side. This is of considerable benefit in supporting the tree during the first year or two against heavy winds.

In marking out the spots for pits several methods are adopted. On fairly level land and across the faces of slopes a line can be used, with coloured cotton or knots at the distance apart it is decided the pits are to be made-say, $4 \mathrm{ft}$. This system, however, is not applicable to steep broken land. as, if the line is put down on a hillside having a slope of $45^{\circ}$, the spaces would be barely $3 \mathrm{ft}$. apart, measured on the level. On such lands a measuring-stick, cut to the same length as the distance between the pits, is used. This is held level while marking one row of holes only by a slight cut with a spade. This row of pits is then opened as a guicie for further marking of holes lengthwise. In orier to keep the next and succeeding rows of pits parallel to and at equal distances from the first row several flags on standards are set up at right angles. Three or more sets of these flags will be required, placed two, three, or more chains apart, so that the workman can always keep two sights in front of him as a guide for direction. The second row of pits is then marked outnot opposite the pits in the first row, but midway between them. The third row will then be opposite the first row, and the fourth row opposite or at right angles to the second, and so on; in other words, in triangular order. Should any difficulty be found in marking out the pits in this form, it is a convenient method to mark out and dig pits in every second line, and afterwards dig a row of pits in the rectangle formed by four pits. The special advantage of the triangular order of planting is that every tree is surrounded by six of its neighbours at equal distances from each other, or, combining six of these triangles, each tree is in the centre of a hexagon. (See sketch 17.) When trees are thus planted there is much less probability of side branches being developed, as each tree is crowded evenly all round; whereas by planting in squares each tree has four trees at equal distances from it and four trees at nearly onehalf the distance. - (See-sketch.).

Where the land is of a harsh stiff nature the pits for trees should be opened some months before planting is commenced, to allow the earth which has been removed to be exposed to the mellowing influences of frost and rain, thus reducing it to a fine powder, the result of which will be beneficial to the trees and a saving in time during planting. Should the land be covered with a strong sole of grass, it will be necessary to remove a thin turf where the hole is to 
be opened and for a space of several inches surrounding it, so that the tree will not be liable to be choked, and also to allow of the soil taken out of the pit being put on a clear space in order that it can be lifted cleanly and expeditiously at the time of planting. It is also of importance that the soil taken out of the pit be placed in front of or opposite to the perpendicular back wall, as by so doing it is then in a convenient position to be replaced. YSee Plate 15.)

The proper method of planting, is also illustrated-in this plate. In solne cases a lad carries the plants and holds the trees in position for two men, and as soon as the whole of the soil is filled into the pits the lad leaves the tree and places another in position for the second man while the first is firmly tramping the soil. When the soil is dry tramping cannot be overdone; but when it is inclined to be moist a gentle pressure of the foot will be sufficient, leaving the final tramping until the soil is thoroughly dry. Care should be taken that only one plant is brought out of the bag at a time, otherwise there is risk of failure through the roots becoming dry. Any long straggling roots which, extend beyond the depth of the pit should be trimmed off before leaving the nursery, as roots forced into a pit in a cramped position necessarily retain that form as long as the tree lives.

On the outer edgés of all exposed plantations two or more rows of dense-growing trees should be planted, in order to afford shelter to the more valuable trees within. Pinus Austrjaca, Pinus muricata, and Spruce Fir are well adapted for this purpose. (See Plate 26.) It may be necessary to remove every alternate tree in these outer rows when crowding takes place; so that space for branch-development is afforded and every inducement given to maintain density of foliage to the ground.

\section{Distance between Trees in Planting.}

Perhaps there is no more difficult subject connected with forestry than defining the correct intervals at which trees should be planted. This is especially so in a new country like New Zealand, where no artificial forests have as yet even half-matured to serve as a. guide. The conditions of soil, climate, and aspect are generally so different here from those of the older countries of Europe that we cannot altogether be guided by the results of experience gained in the Northern Hemisphere, and yet to a certain extent we must look to the Old World and judge the results attained by close or wide planting, on poor, medium, and rich soils, in varying sitnations and widely different aspects, before we are able to arrive at an intelligent conclusion or the subject. That Great Britain has for hundreds of years erred on the side of too wide planting, too heavy thinning, and consequently the production of knotty and worthless timber, is an established fact, but happily there are now signs of conforming with the more advanced views of other nations which have for hundreds of years adopted Nature's method as their guide in timber-production. The older schools of British forestry advo- 


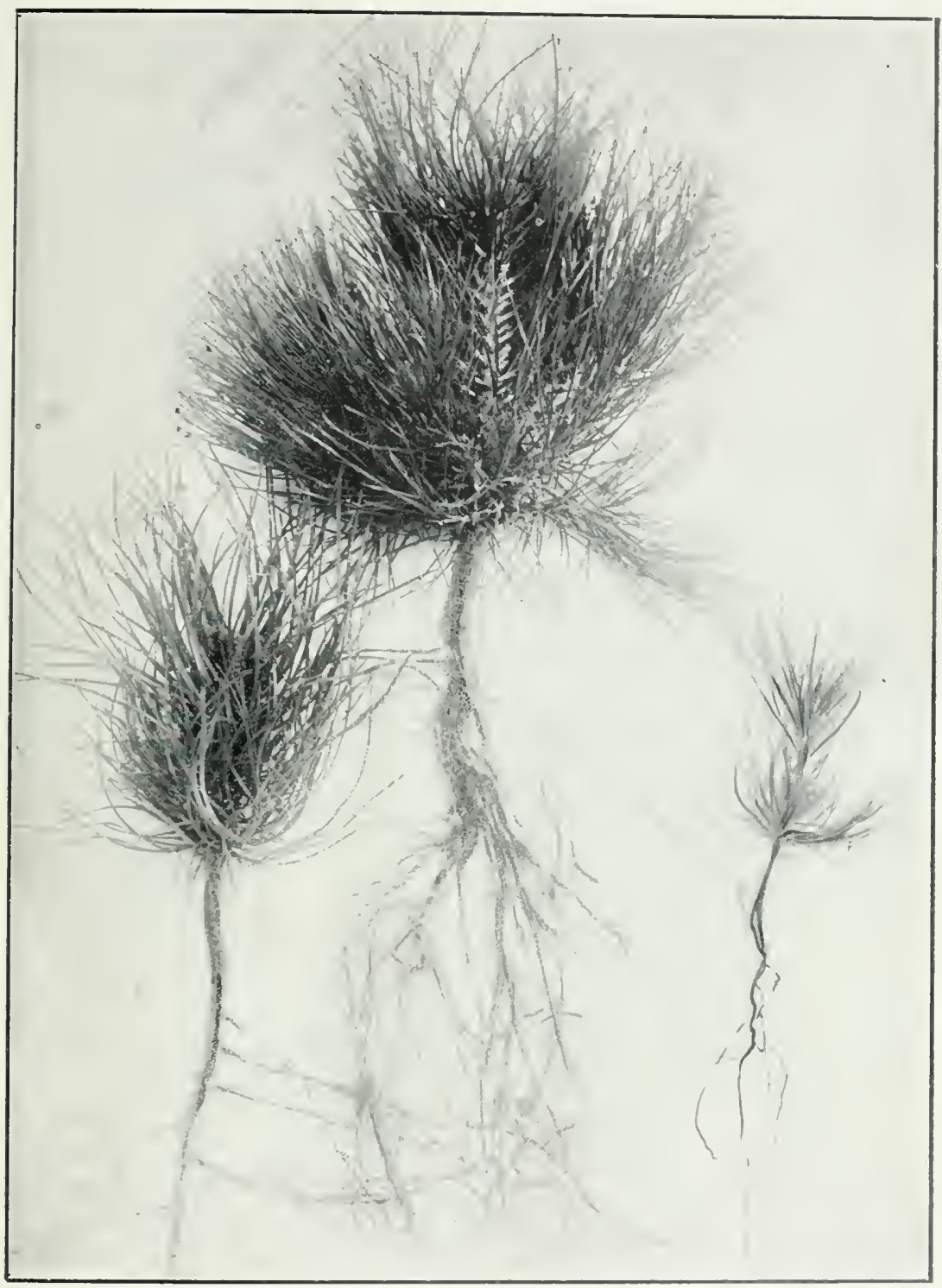

AUSTRIAN PINE (PINES ACSTRIACA), ONF, TWO, AVD TIIRE YEARS OLD, Plate 13.]

[Face p. 24. 

cated planting only as many trees on an acre as the German forester would leave after the first thinning, in thirty or forty years from the time of planting. Mr. John Simpson, of Sheffield, was the pioneer of the new forestry (as it is termed) in Britain, and is also the author of a work known by that name. This book (published in 1900) is a clear and concise treatise on the Continental methods of sylviculture applicable to Great Britain, and is well worthy of careful perusal by students of forestry.

In all natural forests regeneration occurs by means of patches of seedlings springing up in gaps formed by the falling of old or dead trees. The individual plants in these groups are not of the same age, are frequenty of various species, and are excessively thick and crowded. Those first in the field will stand the best chance of success, but even the biggest and strongest will be obliged to struggle with their numerous lesser neighbours, and in so doing will lose their side branches in early youth. This struggle for existence and "the survival of the fittest" goes on for all time, and it is by this means that long, clean-boled timber is produced by Nature. Nature, however, is wastefui in her methods, which are characterized by extreme lavishness in her system of reafforestation, and probably not one seedling in a thousand reaches maturity. Advanced sylviculture copies Nature as nearly as possible in her system of dense crowding during early youth, and reduces waste and time to a minimum. The commonly accepted belief is that if a young plantation is allowed to become crowded and the branches die off the trees are ruined beyond recovery, whereas this density and crowding to prevent the formation of branches and the development of the main stem in height-growth is precisely what the forester aims at. Unless the killing-off or suppression of side branches takes place before the main stem has attained a diameter of only a few inches, rough, knotty, and unmarketable timber will be the result, and no amount of skill can remedy this defect. The sceptical have only to atiempt to split the trunk of a well-branched Cupressus macrocarpa to be convinced that each branch from the main stem means a knot in the trunk. In Germany, where forestry is probably better understood than in any other country, young trees are planted as close as $2 \mathrm{ft}$. apart $(10,950$ per acre) in exposed positions, and never wider than $4 \mathrm{ft}$. apart (2,72: trees per acre) on low-lying moderately rich soils. The aim is to cover the ground as quickly as possible and secure density overhead, or an uninterrupted canopy to protect the soil from the sun and wind. This close culture is maintained until the necessary height-growth is reached before thinning takes place. The appearance of a German forest at, say, from thirty to forty years of age may be compared to a crop of giant wheat - the ear representing a thin tuft of foliage at the top of the slender stems. In this colony, however, we have not the extremes of climate experienced in central Europe-although the past winter (1903) has, especially in southern inland districts, been of exceptional severity-and tree-growth generally is nearly twice as 
rapid here as in the colder parts of Europe, consequently a less number of trees per acre is necessary to secure the same results as are obtained by the excessively close planting practised by German foresters.

Important factors in deciding what number of trees should be planted per acre are the species of tree, the soil, the climate, the aspect, and the elevation. It is impossible to enter into detail on these subjects without extending this work beyond reasonable limits, and probably there are few amongst the farmers of this colony (for whose information this is being written) who would be sufficiently interested in or have the necessary leisure to peruse what would probably be to them a dry subject. Shortly, it is the practice of this Department in planting high, exposed, poor lands (either with seed in situ or small plants) to space at $3 \mathrm{ft} .6 \mathrm{in}$. apart; at lower altitudes, in medium soils, at $4 \mathrm{ft}$. apart; and for Eucalyptus, Catalpa, and other fast-growing timber-trees in the free open pumice lands of central Auckland at $6 \mathrm{ft}$. from tree to tree. These distances, however, are not always strictly adhered to, as varying circumstances necessitate modification.

Trees grown generally in accordance with the methods which have been outlined will form clear stems and small crowns of foliage, and, although many weak trees will succumb and be removed as time goes on, one condition, and that the most important of all, is assured in those that attain maturity-viz., freedom from knots through the absence of branches.

Any thinning that may be necessary should be done with extreme caution, as large openings made by the removal of more than one tree in a line tend to the undue development of branches at the expense of the stem. Whether it is desirable to delay general thinning in New Zealand plantations until the twentieth or even thirtieth year, as is the practice in Germany, where the results fully justify this procedure, is a question which must be solved by a longer experience of planted woods than we yet possess. There is, however, no doubt about the necessity of maintaining density during the principal height-growth of the trees if clean-grown, commercially valuable timber is the desideratum.

The success and ultimate value of the plantation will depend largely on constant attention by preventing a too-strong growth of grass and other rank vegetation from choking the young trees. This is especially necessary during the first year or two, as heavy tall grass or feru is apt to get laid and to smother the young plants. Strong winds will also do much injury to newly planted trees by swaying them about and giving them a "lean." In such cases setting upright and firm tramping are necessary to prevent them growing up with an unsightly bend in the trunk.

It will frequently be found that odd plants of Oak, Ash, and other deciduous trees become stunted in growth through barkpeeling by rabbits or hares, or accidental damage through heavy winds. The only successful remedy in such cases is to cut them 


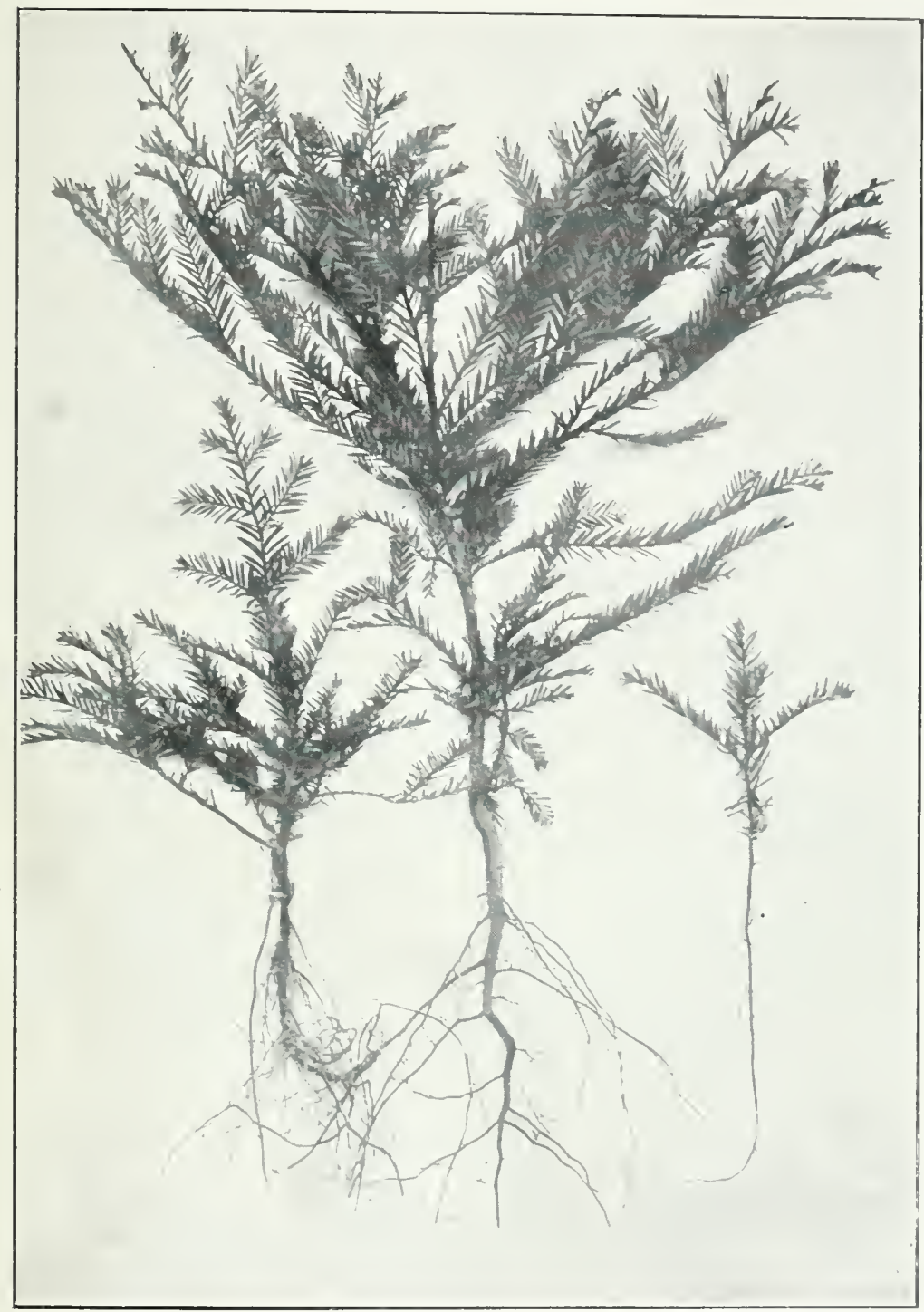

CALIFORNIAN REDWOOD (SEQTOIA SEMPERVIRENS), ONE, TWO, AND TIIREE Plate 1:.] YRARS OLD.

[Face p. 26. 

clean off close to the ground with a sharp knife, or a slasher if the stems are large. If this is done in early spring a number of strong growths will follow, the best and straightest of which should be left, and the others removed close to the point of union.

\section{Deep or Shallow Planting.}

A great many failures occur through too deep planting of trees, more especially in windy localities. where they are frequently put in deep with the idea that it may save time and trouble afterwards in straightening them up or "staking." It is better to err on the side of planting too shallow, for then the plant can assist itself by sending its roots out for support or down in search of moisture; whereas when a tree is planted too deep it cannot produce roots above the collar to maintain itself in an erect position.

Failure through deep planting is most common amongst coniferous trees, which usually have a somewhat top-heavy appearance, and they are generally planted low to prevent them being swayed to and fro by the wind. By so doing there is considerable risk of f'ailure, as these trees are not adapted by Nature to send out fresh roots near the surface to afford support. On no account, therefore, plant a tree of any description deeper than it stood before lifting; let the collar of the root be exactly level with the surface of the ground, or, if in wet situations, rather above it. In all well-grown nursery stock the mark indicating the depth at which the tree previously stood can be easily seen.

\section{CHAPTER VI.}

\section{THE PRUNING OF TREES.}

F CREES differ so much in habit and in their rapidity of growth, and are so largely dependent upon the soil and" situation in which they are placed, that it is impossible to lay down any precise rules for their management in this respect. Where the object in view is the growth of long, straight. clean boles of timber, thick planting and frequent stopping of rambling branches and double leaders will be all that is required in the way of pruning.

Under the chapter "Tree-growth" the evil results of pruning branches from the stems of forest-trees are pointed out. Many broad-leaved trees have a tendency to throw out several strong leading shoots, and unless the central one is assister to maintain supremacy by the shortening of its rivals the height-growth of the trunk ceases at the point of divergence. True, one or other of the shoots will in time attain a leading position without artificial aid, but the main stem will of necessity be bent and rendered less valuable as timber by allowing other than the leading shoot to 
develop. In such a case timely pruning will obviate the necessity of heavy pruning at a later stage of the tree's growth.

Coniferous trees do not, as a rule, produce strong side branches, and, if timber-production be the object, they should be planted so thickly together that branches cannot develop to any great extent before they are naturally pruned by the dense shade. It is, therefore, only when two or more leaders are developed that pruning is necessary.

In mixed plantations the work of pruning is largely increased owing to the variation of growth amongst different classes of trees, and no definite instructions can be given further than to maintain the leading shoot by the suppression of rivals and to shorten back the growth of strong side branches.

On the Continent of Europe, where the relative growth of trees in varying soils is thoroughly understood, the exact species that should be planted together are well known; but in our colony, where forestry is only in its infancy, we have no records available for our guidance, and mistakes must necessarily be made by planters. These mistakes, then, can only be rectified by judicious and timely pruning, bearing in mind, meanwhile, that we cannot advantageously prevent branch-formation unless the trees are so densely crowded as to render the growth of the head to a large diameter impossible.

In regard to pruning ornamental trees, which have much more growing-space to develop their limbs, early cutting-back of strong growths is frequently necessary in order to maintain a proper balance of the crown. Double leaders are also of more frequent occurrence where trees are isolated, and should these be neglected beyond one season there will be some difficulty in remedying the evil. There is nothing more offensive to the eye than a crooked trunk or a double leader in a specimen tree, and these can only be avoided (and at the same time much more satisfactorily rectified) by timely pruning before a decided lead has been established. In ornamental plantations we frequently notice magnificent specimen trees being crowded out and disfigured by their more vigorous neighbours. The damage is generally too far advanced for successful treatment before it occurs to the owner that one or the other must be sacrificed. The inost valuable specimen is then chosen, and the offending neighbours hacked back in the most ruthless fashion. It is generally found that thinning has been too long delayed, and what was supposed to be a perfectly shaped tree has had its lower branches damaged beyond recovery. To make the tree appear evenly balanced it is then decided to trin off all the lower branches to a certain height, which not only disfigures the tree bat produces an effect that is unknown in Nature. Such mutilation cannot be too severely condemned, and yet few ornamental plantations in the colony are free from such blemishes. In such plantations when one tree begins to encroach on another it must be at once decided which is to be sacrificed, and in place of hacking back the offender 


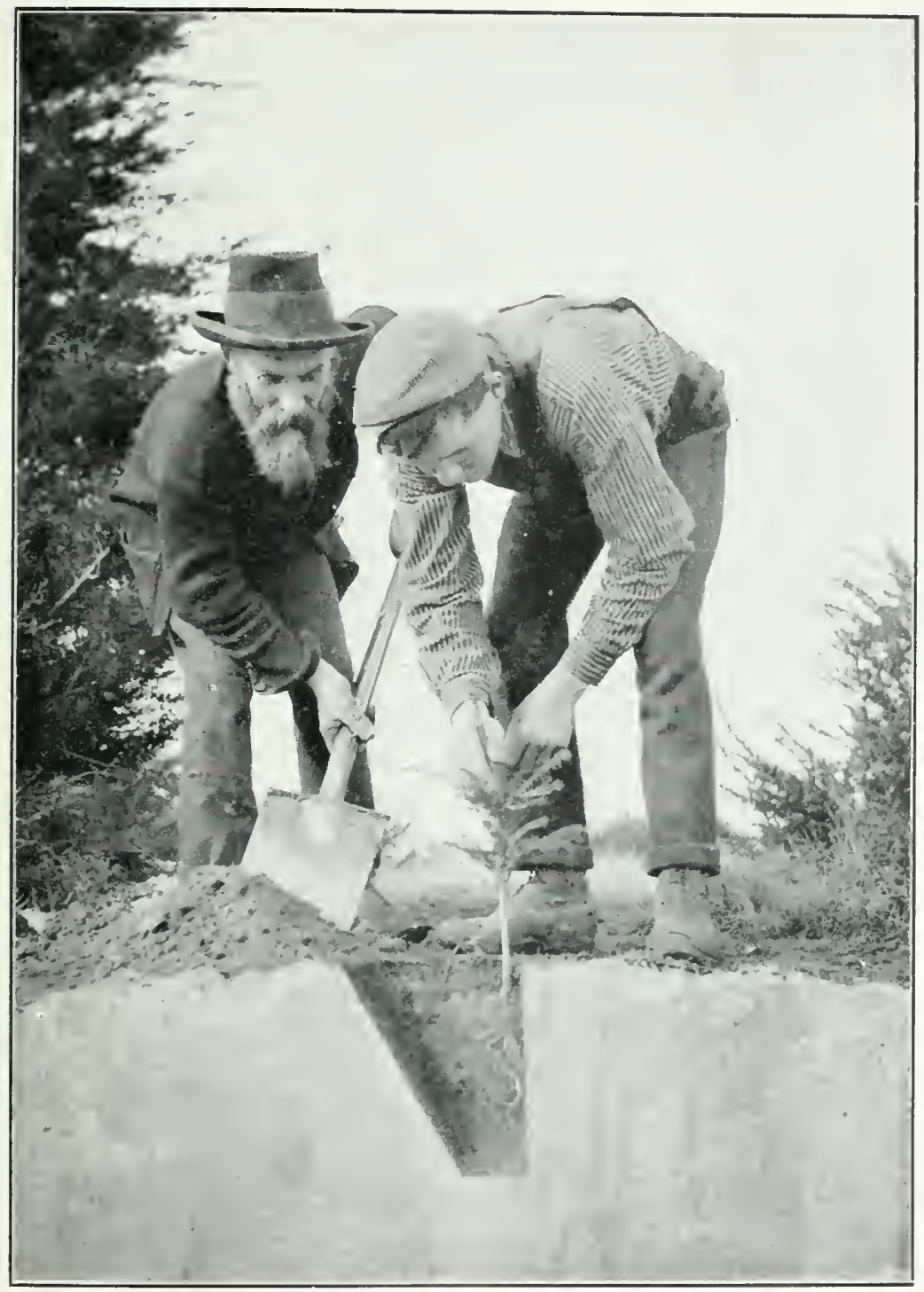

FOREST-TREE PLANTING IN OPEIRATON： SECTIONAL VIEW, SHOWING SHAPE OF PIT IXI) POSITION OF YOUXG TIEE.

Plate 15.]

THuce p. 28. 

let it be cut down and removed. Another common practice frequently observed (especially in small areas) is the trimming of trees into pyramidal or other shapes. This is another custom of the "dark ages," which not only spoils the natural habit of the tree, but converts it into the similitude of the Noah's-ark tree of our childhood.

The necessity for thinning out valuable trees in ornamental plantations is largely due to want of systematic arrangement at the outset. How frequently do we find huge-growing trees planted within a few feet of a gate, a drive, or another tree. Such look very well for a time, but gradually the branches begin to encroach beyond their legitimate limits, the offender is cut off, and this process is repeated until the tree reminds one of an apple with a bite taken out of it.

Before planting ornamental grounds it would be well to consider the probable dimensions any given tree is likely to attain, erring rather on the liberal side than by restricting its limits unduly. If the position of each is then assigned, let the intervenung spaces be filled up with a less valnable class of tree, to act merely as tem. porary occupants until the permanent and more valuable specimens demand their removal. If ornamental plantations are carried out on these lines there will be ferrer examples of the mutilation now so prevalent, and pruning will be confined merely to rectifying slight defects in the balance or leader's of the trees.

Where the lopping of large branches is rendered imperative through previous neglect, first cut a notch out of the under-side of the branch close to the stem with the saw; then start on the upper side, when the bough will be severed without tearing the bark away from the lower side. If the wound is a large one, Stockholm tar or paint will prevent moisture penetrating into the cut and thus causing decay. For branches up to $1 \frac{1}{2} \mathrm{in}$. in diameter no tool will be found so efficient as a $2 \mathrm{in}$. firmer chisel fitted into a long handle and struck with a maliet.

December, January, and February will be found generally the best months for tree-pruning, as most trees feel the operation less when in vigorous growth. The motion of the sap is then active, and the wounds will heal with a minimum of discharge, owing to the sap being fully utilised in building up new wood. Several fast-growing deciduous trees, such as Sycannore, Birch, Alder, anci Maple, are liable to profuse bleeding at the wounds if pruning is done too early in the season, and in the case of such species pruning should be deferred until active growth for the season has ceased. 


\section{CHAPTER VII.}

\section{SOIL S.}

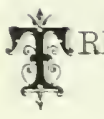

REES more than any other crop require a certain layer of soil iuto which their roots can penetrate, not only for nourishment, but also as a means of ensuring stability. The growth of trees on land are good, though not infallible, indices of the value of the soil for agricultural purposes. The farmer, dealing almost entirely with the top or surface soil, can by inquiry find out what his soil contains or is deficient in, thus enabling him to grow the crop best suited to his land. With the forester, however, the subsoil is also a most important consideration, and he cannot add chemical compounds to fit the soil for growing trees otherwise unadapted for the purpose. It will not be sufficient to merely examine the surface and then decide what trees are suitable for the soil : the subsoil must be tested in order to ascertain what the trees will have to draw upou in years to come, and winether the underlying stratum is permeable by tree-roots aeep into the ground; for if their downward course is interrupted by a layer of tenacious clay, hard-pan, or an impenetrable bed of rock the tree cannot attain its full growth and ievelopment.

The farmer will seldom plant trees on his best and most fertile lands, which can be more profitably utiliseci for grain, root-crops, or pasture. He will devote chiefly such lands as are unremunerative for cropping-steep and broken hillsides, swamps, and poor stony or sandy solls-as sites for plantations. He will therefore require to select such trees as are suitable to the soils and sites arbitrarily chosen for him, and it is here that the foundation of future success or fallure chiefty lies. Aspect, exposure to prevailing winds, minimum and maximum temperatures, elevation, and rainfall are also factors that have to be taken into consideration when deciaing what trees can be grown successfully to be of most profit for general requirements, either for shelter or the procinction of timber.

From the foregoing it will be seen that there are many circumstances to be taken into consideration when deciaing this important step, and while a general idea can be given as to what are the requirements of rarious species of trees it is ourions that no hard. and-fast rule can be laid down as a guide in selection. This is particularly so in New Zealand, where the climate is necessarily widely aiverse through the fact of the Islands stretching over a thousand miles from north to south, which renders possible the growing of semi-tropical regetation at one end of the colony, while at 


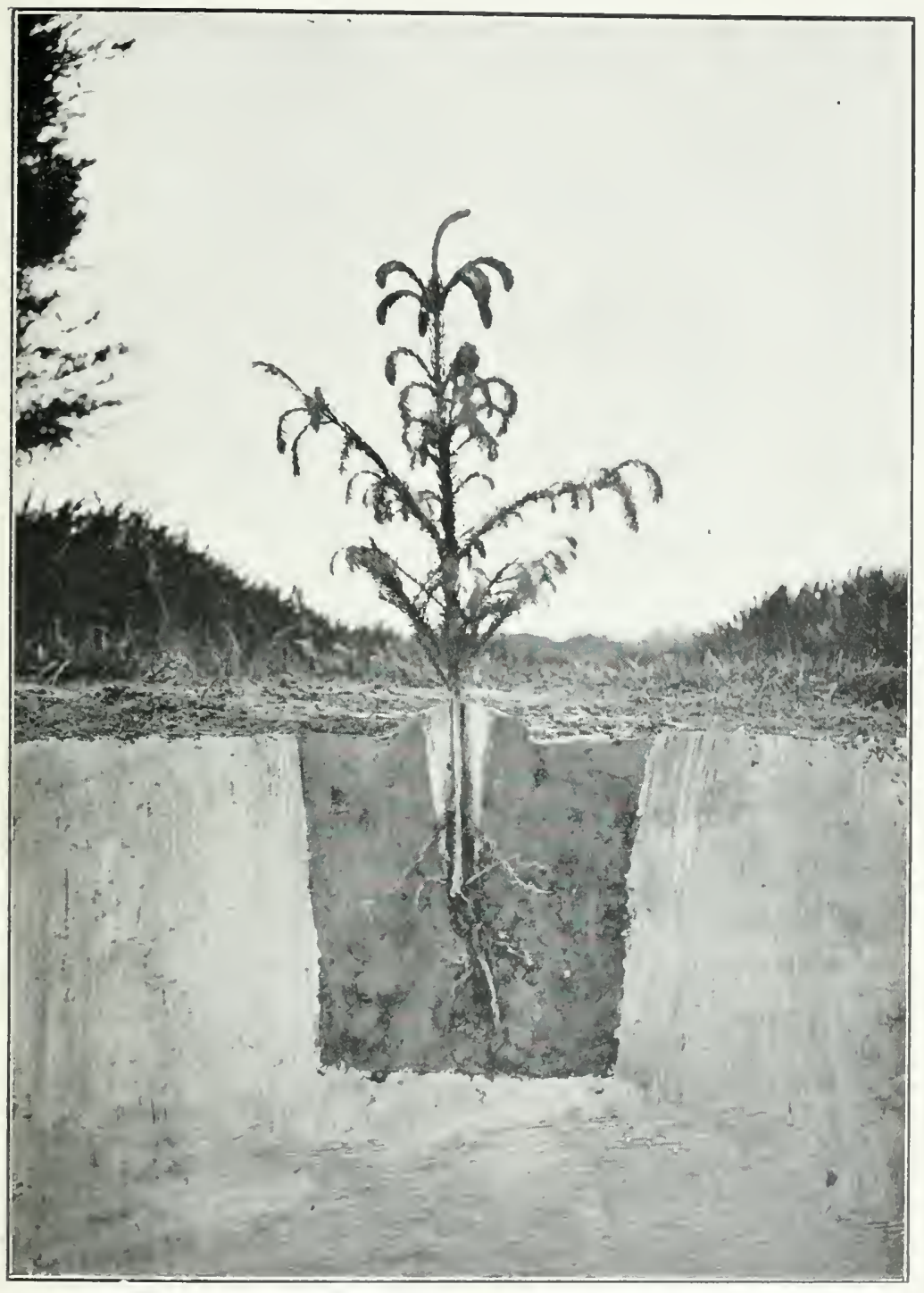

Plate 16.]

1 FOREST TREE WRONGLY PLANTLI).

[Fuee 1). 3\%. 

the other end the selection of trees and shrubs is restricted to a limited number because of the more rigorous winters. The soil, too, is as variable as the climate, as is also the rainfall, which is abnormally great on some portions of the west coast in the South Island (no less than $130 \mathrm{in}$. per annum having been recorded) and much below actual requirements in Central Otago and many east coast stations throughout both Islands, where a fall of only $10 \mathrm{in}$. per annum has been registered. The variations of soil, however, throughout the Islands are of secondary consideration, as we have practically the whole world to draw upon for our selection of trees, and can therefore accommodate each species according to its special requirements.

An elementary knowledge of soils and their compositions is of much service to the tree-planter, but the subject is too large and technical to be dealt with here, passing notice only being permissible.

The formation of soil is due to a variety of agencies, which are either of a chemical, mechanical, or organic nature. All soil is origivally the result of the decomposition of rocks, with certain organic substances added. It does not, however, necessarily partake of the exact character and ingredients of the rocks immediately underlying or adjacent, as frequently the original soil has been carried away by violent convulsions, or by the action of water, and deposited elsewhere. In the formation of soil by mechanical agencies heat and water are the chief facturs. Strain and pressure is caused by the heating of rocks, which are burst asunder, allowing water to percolate into the fissures. The water then freezes and forces the rocks apart in all directions. Chemical action aids disintegration by dissolving certain elements in various rocks, such as lime, potash, soda, and magnesia.

Mechanical and chemical action having paved the way for organic agencies, it is now possible for the lower forms of regetable life to exist. Lichens and mosses are the first to appear, and by keeping the surface moist they assist in accelerating decomposition. The surallest fissures are sought out by thread-like rootlets, which in time decay and form humus, thus enabling higher forms of plant-life, such as grasses and herbs, to subsist. Shrubs and trees follow, and with their stronger root systems penetrate in to every crack and crevice that has been reached by their pioneers, thereby further accelerating decomposition. Thus soil is gradually formed of remnants of dead vegetation and particles of rock, slowly but surely deposited on the earth's surface, layer after layer, in varying depths during untold ages. Trees and other growths are constantly returning vegetable matter to the soil from which they grow, and a dense cover of trees will in time transform the poorest soil into a fertile one, as has been frequently exemplified in France and other countries where tree-plinting has been resorted to in order to stay the threatened destruction of valuable lauds by sand-drifts. Barren, shifting sand-wastes have thus been converted into fertile 
agricultural lands, which during the process of reclamation have afforded lucrative employment to thousands of persons in the timber industry, with its by-products, such as the manufacture of charcoal, collecting of turpentine, and production of tar and resin.

The soils of this colony are so varied that it is impossible to describe each kind in detail, but the principal forms may be mentioned in order to illustrate the species of trees that do best on a given soil, provided climatic conditions are in each case favourable.

Soils may be classed under four principal divisions-siliceous, calcareous, argillaceous, and alkaline.

Humus or vegetable soil is chiefly the product of decayed vegetation. When formed in wet or moist places it is usually peat, but in drier localities it forms what is termed "bush mould," which absorbs and retains moisture within the reach of vegetation, thus imparting fertility.

Siliceous soils are principally composed of gravel, sand, or pumice, mixed with clay and humus in varying quantities. Such soils are suitable for most species of Pine, Juniper, Larix, Thuja, Birch, Walnut, Chestnut, Plane, Robinia, Acacia, and many of the Eucalypti.

Calcareous soils are formed from chalk or any kind of limestone. They possess the property of absorbing and retaining moisture, and, although saturated, are not impenetrable to the air. Many kinds of trees are available for such soils, the principal of which are Beech, Maple, Poplar, Elm, Cedar, Lime, Silver-firs, Eucalyptus, and one or two of the Pines, notably Pimus ponderosa and P. strobus.

In argillaceous soils clay forms the principal ingredient. If absolutely pure their capacity for retaining moisture renders them unfit for the growth of many trees, unless well drained. When a fair percentage of sand is present the variety of trees that may be planted thereon may be considerably extended. The principal species for clay lands are Cryptomeria, Pinus Austriaca, Ash, Oak, Thuja, and several Eucalypti.

Alkaline soils are fortunately not of large extent in this colony, although in the central portions of Otago and Canteroury they s re frequently found in scattered patches. These soils are extremely troublesome to the planter, especially as they occur in very frosty and dry localities, where few trees can exist even on the better classes of lands. The excess of alkali appears to be principally due to want of moisture for dissolving and carrying it away. Pinus Austriaca, P. maritima, Laburnum, and Robinia are the only species so far that have proved successful on this soil.

With regard to the species of trees recommended as suitable for various soils, it should be noted that without sufficient rainfall (or its equivalent in irrigation), and unless the conditions of temperature be consistent with the requirements of tree-growth, success cannot be looked for. A suitable degree of moisture to correspond with the natural requirements of particular species is also necessary for the successful growth of trees. Those species which require 
Face p. 32.

Plate 17.

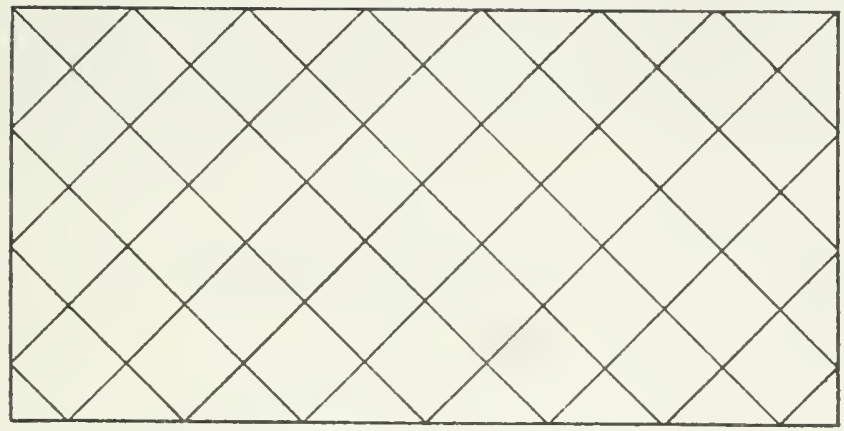

Planting in quincume order.

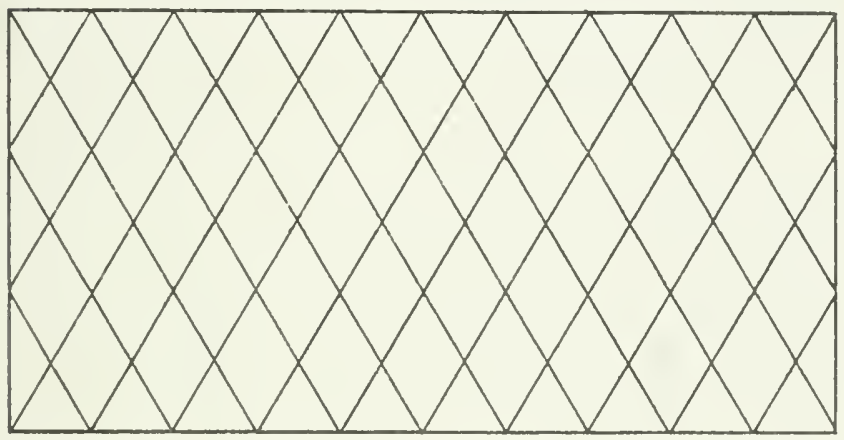

Planting in triangular order:

\begin{tabular}{|l|l|l|l|l|l|l|l|l|l|}
\hline & & & & & & & & & \\
\hline & & & & & & & & & \\
\hline & & & & & & & & & \\
\hline & & & & & & & & & \\
\hline & & & & & & & & & \\
\hline
\end{tabular}

Planting in squares. 

most moisture are Alder, Ash, Poplar, and Willow. Moist soils (without being wet or stagnant) are suitable for Silver-fir, Spruce, Elm, Lime, Oak, Eucalyptus, Catalpa, Sycamore, Chestrut, Maple, \&c. Dry soils are favourable to most Pines, Larch, Austrian and Corsican Pines, Birch, Acacia: Aspen, \&c.

Further details regarding soils, situations, \&c., suitable for various trees will be found under the heading of "Trees Recommended for General Planting."

\section{CHAPTER VIII.}

\section{TREE-GROWTH.}

f. ITHOUT some slight knowledge of tree-growth the amateur forester will labour under considerable disadvantage in dealing with his plantations. It is therefore deemed appropriate to mention briefly a few iacts about tree-growth.

A tree, according to the dictionary, is "a perennial woody plant, usually over $20 \mathrm{ft}$. in height, and growing with a single trunk." It consists of three parts-roots, trunk, and crown.

Roots supply the tree with water and nourishment derived from the soil, but only young roots have the power of taking up water and plant-food, the older roots serving merely to hold the tree in position. In the process of food-absorption by the root-fibres the tree is often aided by fungi in the humus soil, which attach themselves to the minute fibres and prepare nutriment $\mathrm{for}$ supply to the trees in soluble form. Nineral or earthy matters (in solution with water) are taken $u p$ by the roots, and these appear as ashes when any portion of the tree is burnt.

The function of the trunk of a tree is mainly support. The central portion or heartwood is practically dead, and has nothing to do with growth; it is simply a strong framework to support the living parts of the tree. Thus hollow trees are enabled to live and thrive when only a thin shell of sapwood and bark remains.

The crown, with its network of branches, buds, and leaves, plays the most important part in the life of a tree, for it is here that the digestion of its food takes place, as well as the processes of reproduction. Leaves absorb not only heat, but also carbonic-acid gas, and transmit these through tiny channels to the growing fibre of the tree. This process goes on only during the presence of heat and light, and because of the chlorophyll present the leaves and young bark assume their green colour. The fact is a tree is built up more by the sun and the atmosphere than by the soil in which it grows. Leaves are the respiratory organs of plants. A tree breathes for the same purpose as an animal does. In the

Forestry-2. 
leaves breathing goes on through the pores, and in parts of the tree covered by bark through lenticels-small light-coloured raised spots that may be seen on young branches of nearly all trees. This process of respiration continues night and day, summer and winter, but it is most active during bright sunshine.

The process of Nature that regulates the flow of sap in trees is not yet thoroughly understood. All that is known is that the sapwood transmits water from the roots to the leaves, where a portion enters into the assimilated sap and goes to build up the plants, the remaining and larger part passing off as vapour. The amount thus transferred varies according to the species-large-leaved trees, such as Oak, Ash, Elm, Maple, and Plane, requiring much more water for their successful development than Pines, Spruce, and other needle-leaved trees, which naturally affect dry soils and elevated positions. When the amount of moisture for a tree becomes deficient its growth is lessened, and leaves are shed in its endearour to survive. Should the supply continue to decrease (especially in the summer) the tree will finally wither and die. Deep sandy and other porous soils allow the rain to sink quickly out of reach of the roots, whilst land with a compact subsoil of adhesive texture cannot be permeated with water, and is therefore impenetrable by roots.

Reference to Plate 31 will assist in explaining the structure of a tree-trunk. Commencing from the centre outwards, we have first the pith, then the wood, then the cambium-layer, and finally the bark. These four parts are represented by an end section of a one year's growth of Pine immediately above the larger section of a log. The pith is a light cellular substance, produced only during the first year's growth, either in a oneyear-old plant, or the new growth of an older tree. It serves to nourish the buds during the first year of their existence, after which they can procure nourishment for themselves. In most of our native trees the pith almost, if not entirely, disappears; in other trees (as, for instance, the Pine, figured in the plate under notice) it has been reduced in size from $\frac{1}{2} \mathrm{in}$. to $\frac{1}{4} \mathrm{in}$. in diameter by external pressure. Next to and surrounding the pith (in the section of one year's growth) may be seen the first layer of wood. In the section of the log the new layer (or, rather, double layer) is apparently next the bark, but separated from it by the cambium-layer, which will become new wood the following season. The cambium is a single layer of dividing-cells, which add to the bark on the outside and to the new wood on the inside. The sap or nourishment collected by the root-fibres passes upwards through the sapwood or new growth to the leaves, where it is elaborated, and then returned downwards through the liber or inner bark, nourishing on its way the cambium-layer, which is constantly increasing by the dividing of cells, thus forming a laver of new wood on the one side and a layer of new bark on the other. 


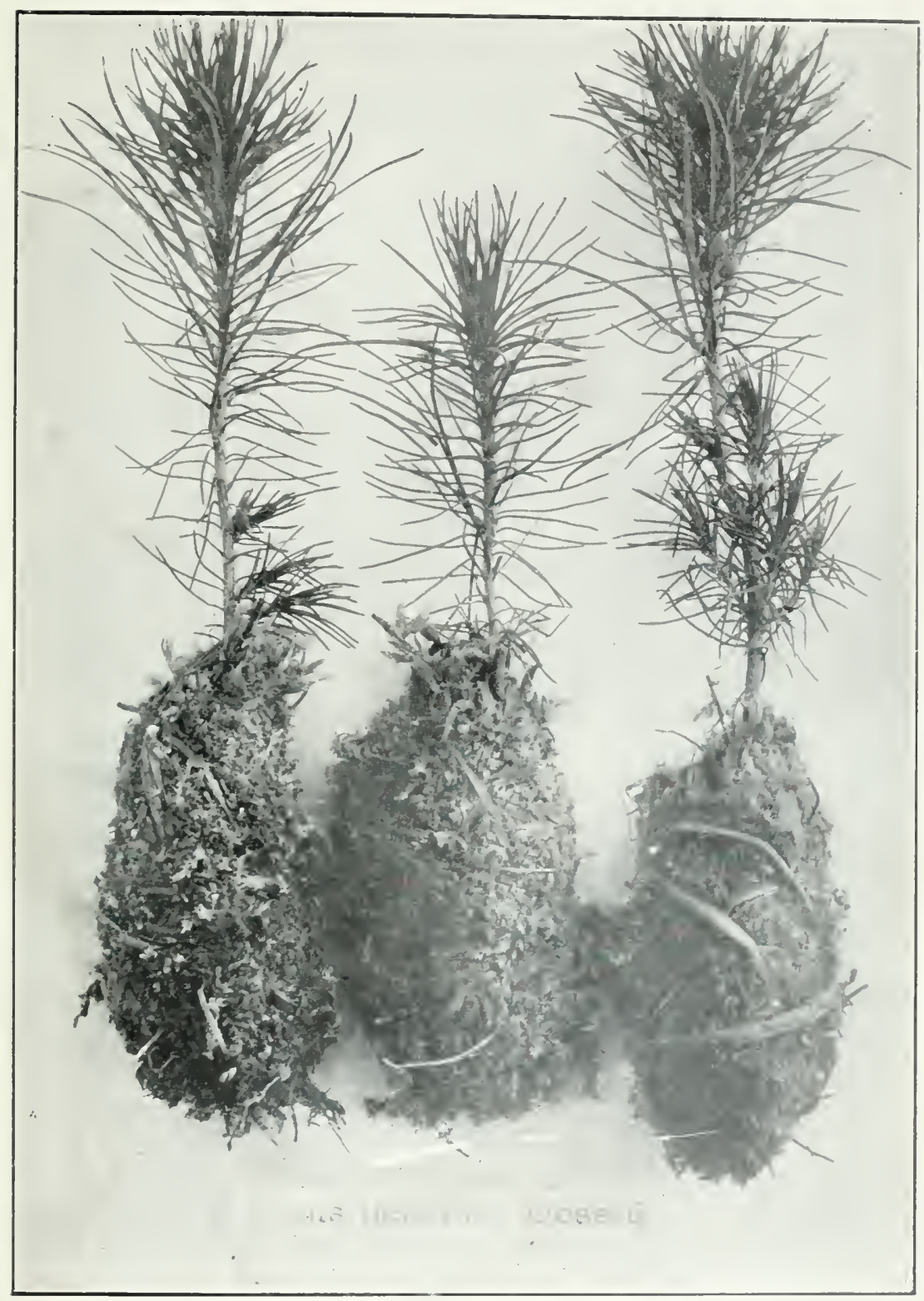

MONTEREY PINES (PINTS RADIITA, SYX. P. IXSIGNIS), MOSSED, SIX MONTIS Plate 18.] OLD. 

In temperate climates, where seasons of active growth alternate with seasons of rest, new wood is formed in two distinct layers, known as spring and summer wood. This is plainly shown in Plates 31 and 32 , the spring wood being much lighter than the summer wood. which is much more dense, compact, and dark in colour. In spring, when growth begins, there is a great demand for nourishment to perfect new leaves, and thinwalled cells with wide openings are produced to allow of a copious supply of water passing upwards. These thin-walled, soft, spongy cells, with their large openings and extremely thin partitions filled with moisture, necessarily produce timber of a light porous texture. At the end of the first season's growth, when new branches and leaves have been former, there is less demand for moisture, and there is plenty of digested food within the cambium-laver to supply building-material. The cells now formed are therefore narrow and thick-walled, whilst the wood then produced is dense, heavy, and darker in colour than the spring-grown wood. The illustration of the Pine log shows clearly the gradual change from sapwood to heartwood caused by intense external pressure. The openings in its cells become so compressed that sap can no longer run through them, and living sapwood gradually changes to heartwood, which is practically dead. Some trees, such as the Eucalypti (especially the common Blue-gum when grown on damp soils), are many years old before their sapwood becomes heart. These fast-growing trees make their wool early in life, and require many years for its maturity. For this reason it is frequently asserted that Blue-gum timber is useless through being grown too fast, when the fact is that sufficient time has not elapsed for its conversion into heartwood.

Reierring again to the illustration, we see that there are seventeen annual growths, each showing both the light spring-made wood and the lark, heavy summer wood. These are the annual rings produced durng the seventeen years' life of the tree. Two false rings do sometimes appear during one year, but they are much thuner than the usual annual rings, and frequently only extend half round the tree-generally, if not always, on the side next to the sun. Where trees are grown in the open, the bulk of timber is always greater on the side exposed to the sun. The formation of false rings is usually due to a season of drought causing a cessation of growth, iollowed by excessive moisture, which induces a second or false growth. The annual increase in height and diameter of a tree may be compared to the slipping-on of a hollow cone between the wood and bark. Each year the cone would require to be longer and broader to fit the one immediately unier it. Every portion of a tree's trunk and branches is thus increased in length and diameter by a layer of annual growth. Au annual layer of wood once formed woes not change its position, but is merely covered by younger layers. Drive a nail at a given height, or staple a fencing-wire 
into a growing tree, and so long as the tree stands these will be at the same height, although buried by successive layers of new wood. The prevalent idea that the trunk of a tree lengthens and carries the bases of its branches upwards is erroneous. The bark covers the whole exterior surface of the roots, trunk, and branches. It is made up of two parts - the outer corky layer (which is dead and merely acts as a protection), and the liber (inner or live bark), through which the sap is returned from the leaves. By reason of the growing ring of wood the bark must stretch, then it finalìy cracks and peels off, being replaced by the inner bark, which is produced annually by the cambium-layer, and is gradually pushed out and cast off.

\section{Knots and their Causes.}

The branching habit in trees is responsibie for the presence of knots in the timber and the irregularities in the grain of wood which is admired for its "figure." Each leaf of a tree nurses a bud in its axil, and each bud is a possible branch. Each branch grows in length and thickness every year the same as the trunk, and shows annual rings on its cross-section; but a branch is always a year younger than the stem from which it sprang. Each year both branch and stem add new lavers of wood and increase their circumference until the base of the limb is enveloped by the thickening trunk. Saw the trunk into boards and the base of each branch is found to be a knot in the timber. (See Plate 32.) Knots produced in this manner are called live knots. Dead knots (or those that drop out of the timber when sawn) are produced much in the same way, except that the branch is killed or cut off in early youth, but is still attached to the trunk, which encircles it with its annual layer of new-formed wood.

Highly figured or wavy-grained timber is chiefly the result of branches interfering with the fibres and preventing them from growing straight. When a branch is met with, the fibre curves to the right and the left and meets again at the top. (See Plate-35.) When one layer of wood is thus added, every successive layer follows, in the same direction, and thus we have curly or figured timber produced, which can be varied in outline according to the skill or taste of the sawyer. The beautiful "figure" commonly known as silver-grain is obtained by cutting a log into two equal parts, or four equal quarters of wedge-shaped sections. This first cutting will show the largest proportion of silver-grain possible, whilst further variations, exhibiting a lessening degree of silvergrain at each successive cut, can be made by sawing the wedgeshaped sections into boards of equal thickness off one side. Looking at the end section of a tree trunk there may be seen thin white lines running from the centre outwards. These are the " medullary rays," whose function it is to convey elaborated sap horizontally from the liber (or inner bark) to the sapwoor. The nearer parallel these are kept with the surface of the board the larger will be the "figure," and this is diminished as the "medullary rays" become 


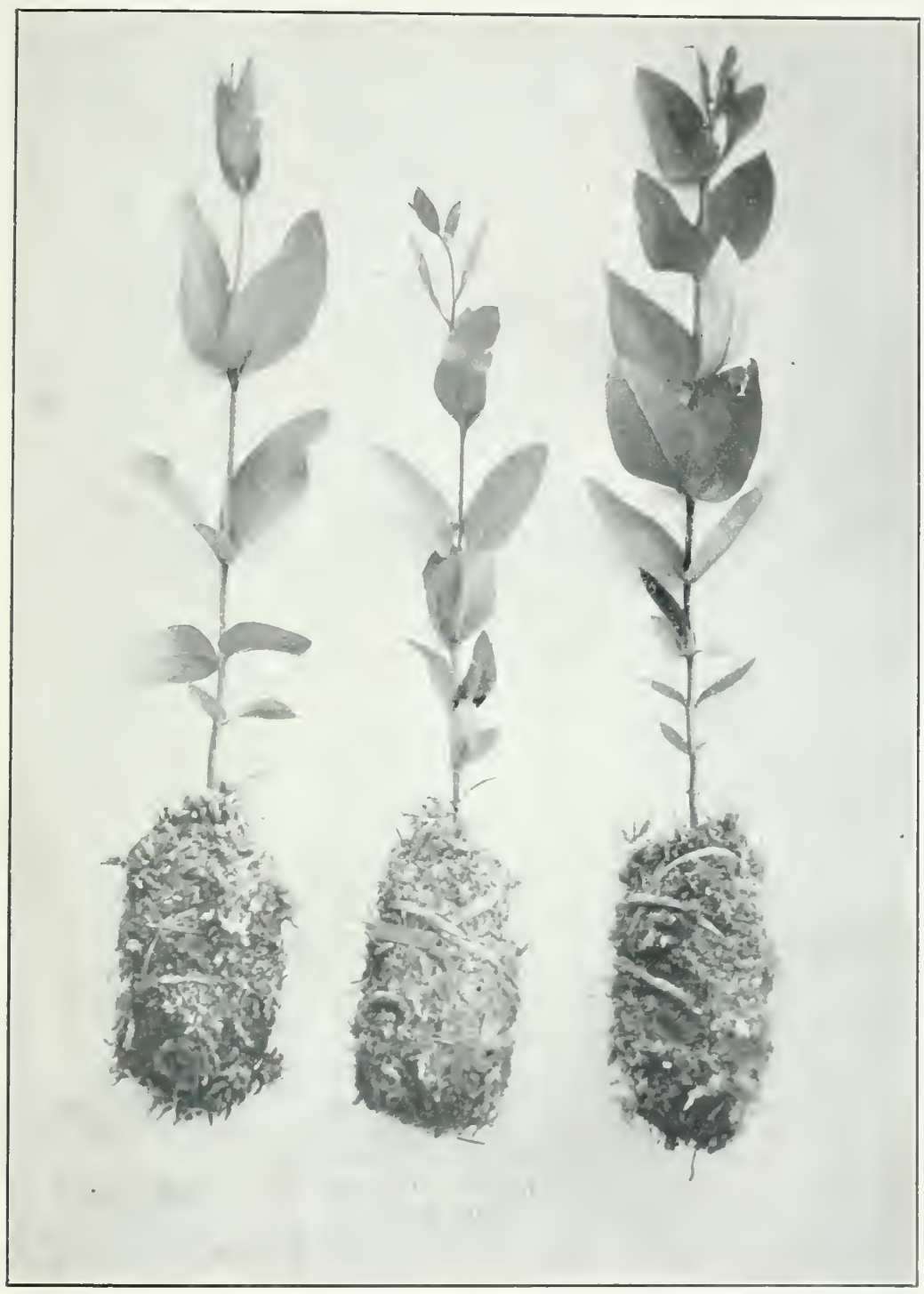

Plute 19.]

ELCAIYTI, MOSSE, SIX MONTHS OLD.

[Frace p. 36 . 

more vertical. (See Plates 33 and 31.) The aim of the forester is to prevent as much as possible the growth of branches by the dense crowding of trees, and to maintain this density until sufficient height-growth is reached; then he thins out gradually, to allow the tree more growing space to increase its diameter. Every side branch developed on a forest-tree is not only absolute waste at the expense of the trunk, but at the union of each branch a knot is produced-large or small, depending on the diameter of the branch when corered by a new layer of wood. NSee-Plate-35.) By no other means than thick planting can timber free from knots be produced.

The pernicious practice of mutilating trees by amputating live limbs close to the stem is pregnant with evil results : it tends to check the growth of even healthy timber; and, althongh the wound may eventually be overgrown by bark, and to all external appearance the sten looks clean and the timber sound, such is not the case, for when the tree is cut up it will be found that the timber around where the branch was cut off is useless. It is a common practice to saw off live branches close to the stem with the professed object of making a clean butt of tirnber; it is, however, a gross mistake and a delusion to saw off live branches close to the bole with a view of assisting Nature in making clean sound timber. After a live branch larger then $1 \mathrm{in}$. in diameter, or when once the heartwood is formed, is sawn off, the wound and aftergrowth of woody layers never unite; the knot will remain a piece of dear or decaying wood, and of course the larger the branch amputated the greater the blemish in the plank when the tree is sawn up. It is by this means that "dead knots" (which usually drop out of the timber when being sawn or aressed) are produced. "A little knowledge is a dangerous thing" is an axion strictly a propos in the case of pruning trees intended for the production of timber.

-These-remarks do not contlict with those made in the chapter on pruning, but are intended to emphasize the necessity for pruning being done when the branches to be removed are of small diameter.

\section{CHAP'TER IX.}

\section{PURE OR MIXED PLANTATIONS.}

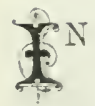

England and Scotland pure plantations of any given species are rarely seen, it having been for centuries the prevailing custom to plant mixed forests, usually containing three or more species. First the standard trees (or those intended to form the ultimate crop) are planted at from $16 \mathrm{ft}$. to $24 \mathrm{ft}$. apart; then midway between each two standard trees another species is introduced, generally of such a nature that its timber becomes useful at 
a comparatively early age-such as Ash. The intervening spaces between the permanent and the secondary trees are then filled up with Larch, or Pines, as "nurses," at irom $4 \mathrm{ft}$. to $6 \mathrm{ft}$. apart. When thinning takes places the nurses are the first to be removed, and later on, when the development of the stanciard trees is being interfered with by the secondary crop, the latter are cut out, leaving the inain crop as the only occupants of the ground.

This system has certain recommendations in its favour, provided the probable growth of each species on a given soil has been previously determined with some degree of accuracy, otherwise it is probable that the rrees intended as nurses may be more suited to the soil and situation than the permanent trees, and by their rapid growth may eventually dominate and supplant the trees they were merely intended to shelter and protect. What may possibly be considered a redeeming feature in the system is that should the standard trees fail to maintain their expected supremacy owing to error in selection to suit the requirement of the soil and climate, the secondary trees are available as the ultinate crop.

Against this system we have the fact that on any large extent of land intenied for planting there exists such diversity of soils and aspects that it would be practically impossible to select a mixture suitable alike for the varying conditions obtaining. There are, however, occasions when mixed plantations can be made with adrantage, such as when planting Oaks as permanent trees and filling up with Larches, the latter to be removed for fencing-material or sleepers when they have fulfilled their purpose as nurses. The Larch will generally be found the best of all trees for planting along with more valuable species, such as Douglas Fir, Tideland Spruce, \&c., provided the soil and situation are alike suitable for its development.

In deciding what species of trees should be planted together the most important points to be considered are-(1) That the relative growth of the varieties forming the mixture slould be equal, otherwise the more rapid grower will eventually suppress the slowergrowing tree; (2) that the soil, elevation, rainfall, and climate are favourable to the species selecteri. Generally speaking, however, plantations of one species only will be found the most desirable for planting by the farmer, who has seldom the time or the necessary experience to succes:fully deai with the complex subject of inixeriforest planting and its suibsequent management. Pure plantations are easily managed by reason of their even growth, trees can be selecter to suit any soil or aspect, and there is no trouble in arranging the ietails incidental to mixed planting.

On any extensive area will be found patches of rich loam; close by, graveily light soil; and on rilges, poor rocky débris. Some parts will be sheltered, others exposed; here the soil is wet, there it is ciry, and so on. It is thus impossible to utilise the whole of a plantation to the hest advantage by planting any one mixture of trees throughout, but the system of pure planting permits of accommodating each kind of tree to its special requirements--the Oak, 


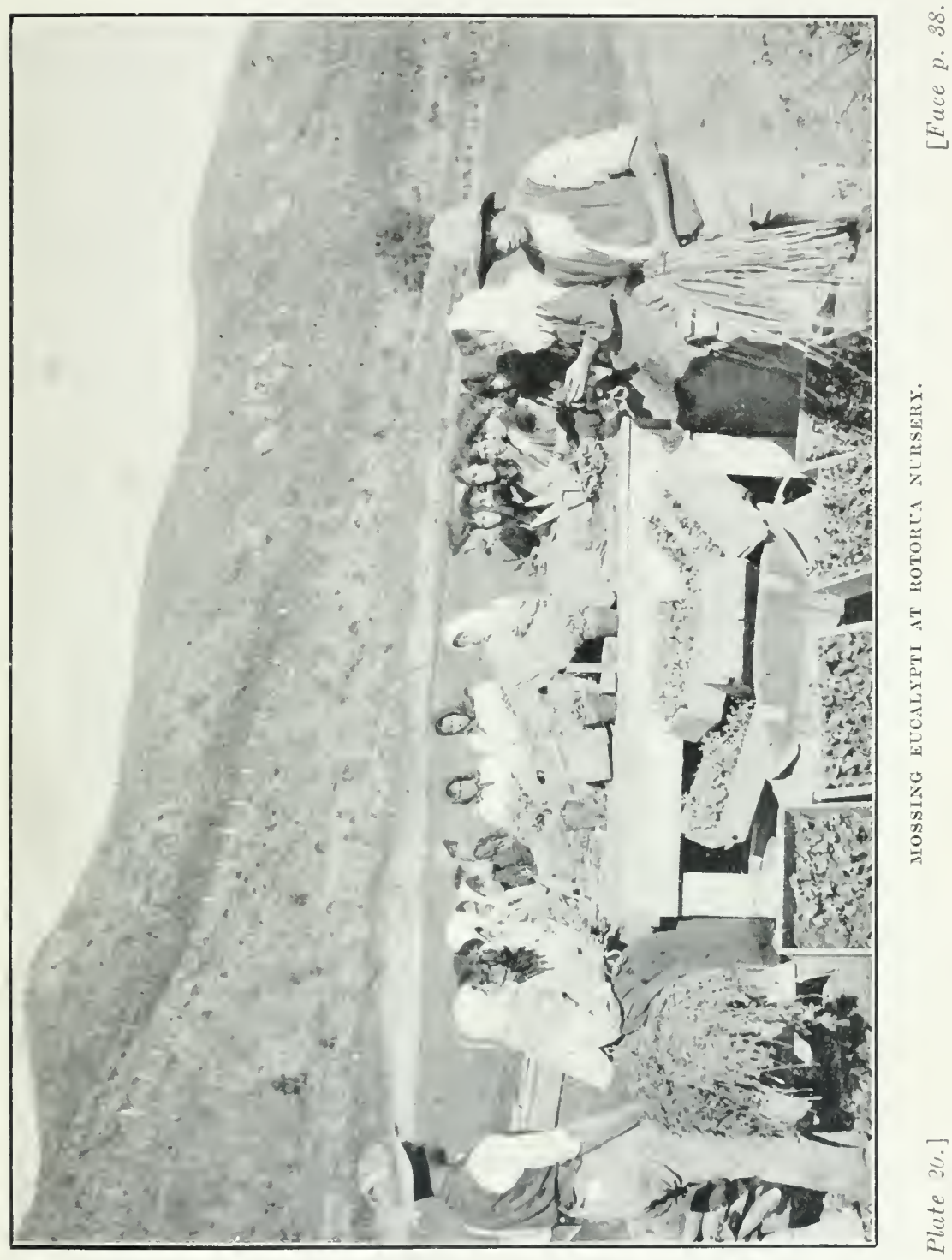



Ash, Elm, and the Piceas on the rich loam; the Larch on the gravelly light soils; and the Pines and Birch on the rocky ridges.

In Germany and the Continent of Europe generally, nixed plantations are the exception, and, although occasionally two kinds of trees may be planted together, nearly all the forests are laid out on the grouping system of pure planting-viz., wherever the soil and situation favour the growth of a particular tree that tree is planted pure.

On the margins of all plantations a few rows of dense-growing evergreens should always be planted, more especially when the inner portion comprises deciduous trees. Spruce Fir, Pmus Austriaca, and Pinus muricata (see Plate 26) will be found the most effective in forming a dense compact growth to prevent cold winds blowing through the plantation, particularly during winter and early spring.

\section{CHAPTER X.}

\section{SHELTER-PLANTATIONS ON THE FARM.}

$e^{-1}$ RMERS as a rule do not go in for much tree-planting, except perhaps a few shelter-trees around their homestead. This probably arises from several causes, one of which no doubt is that they think the land can be turned to more profitable account by employing it for the ordinary stock-raising or crop-growing purposes of the farm. This is doubtless true where the farmer has only a short lease of the ground, but when he is the owner, even when he does not intend to make the farm his permanent home, it will pay him to plant. When he comes to sell, if the intending purchaser visits the farm on a windy day and sees the sheep feeding restlessly to windward, or seeking the poor shelter of some gully, he will form a very unfavourable opinion of the place compared with that which he would form if the tlock were contentedly grazing in a paddock sheltered by a belt of trees. It is distressing to see horses and cattle go round fence-lines in all directions in search of a shady nook or corner to protect themselves from the perpetual teasing and torment of flies, not to mention the intense heat and glare of the scorching sun. In contrast to such sights of live-stock in a state of restless torment, how refreshing it is to witness them enjoying the cool shade of trees! Cattle especially prefer to feed at night or in the cool of the morning or evening during very hot weather, and to lie in the shade and chew the cud during the burden and heat of the day. Peace and contentment are as essential to the production of milk of the best quality as to tire putting-on of beef, and when these influences on the milk and meat supply are duly appreciated every paddock will have its clump of trees to shelter the stock, 
both from the cold and blasting winds of winter and the heat and torment of flies in summer. When such necessities are provided it will be the first step towards combining landscape beauty with the economy of grazing and farming for mere profit. The dearly bought experience of the past winter (1903), especially in Canterbury, Otago, and Southland, through loss of sheep and lambs ought to convince farmers resident in exposed localities of the utility of wind-breaks.

Another point is that the purchaser in making his valuation would assuredly take into consideration the value of the supply of fencing-material to be obtained from the woods. The crops, too, would benefit, for better growth would be induced and the loss from "shaking" be greatly lessened.

Probably many a farmer seeing a belt of trees planted along the side of a large paddock, and observing that the grass along the fence-line within reach of the roots was poor, might think that the owner would have done better had he kept the planted land in his paddock, as it would have been so much additional area, and no part of the paddock would have been impoverished by the tree-loots; and probably such a man would not have believed it had he been told that the carrying-capacity of the paddock had been increased-not diminished-by the plantation, and that the shelter would more than make up for the area lost. There are too many people in this world who can only see what is too apparent to be overlooked, and who cannot realise the cause of some indirect benefit or injury which requires a little thinking or trouble to discover. These are the people (who, in the words of the proverb, "Draw at the spigot and lose at the bunghole." This "penny wise and pound foolish" spirit, it is to be feared, influences many farmers in preventing them from planting trees. They grudge to lose the land and the cost of fencing, and think that the only benefit to be derived from the planting - that is, the future value of the timber--is too remote to be a sufficient inducement to incur the expense of planting trees on the farm. In this they elr, for in a very few years the benefit of the shelter would begin to be felt, and would be more apparent and effective year by year.

Settlers generally are too apt to consider bushland as something to be cleared and not to be perpetuated. They will clear the natural bush to the last piece of scrub, and then plant some worthless exotic tree as shelter, of little use either as fuel or posts when the necessity for thinning becomes imperative. It is not until the necessity arises of buying coal for domestic use that they awake to the fact that they could have profitably produced fuel for home consumption on unproductive portions of the farm practically free of cost. The growing scarcity of fuel and fencing-material in our native forests is annually becoming more acutely felt, and if this is true at the present time we may reasonably expect the cost of these necessary commodities to be prohibitive within the next twenty years 


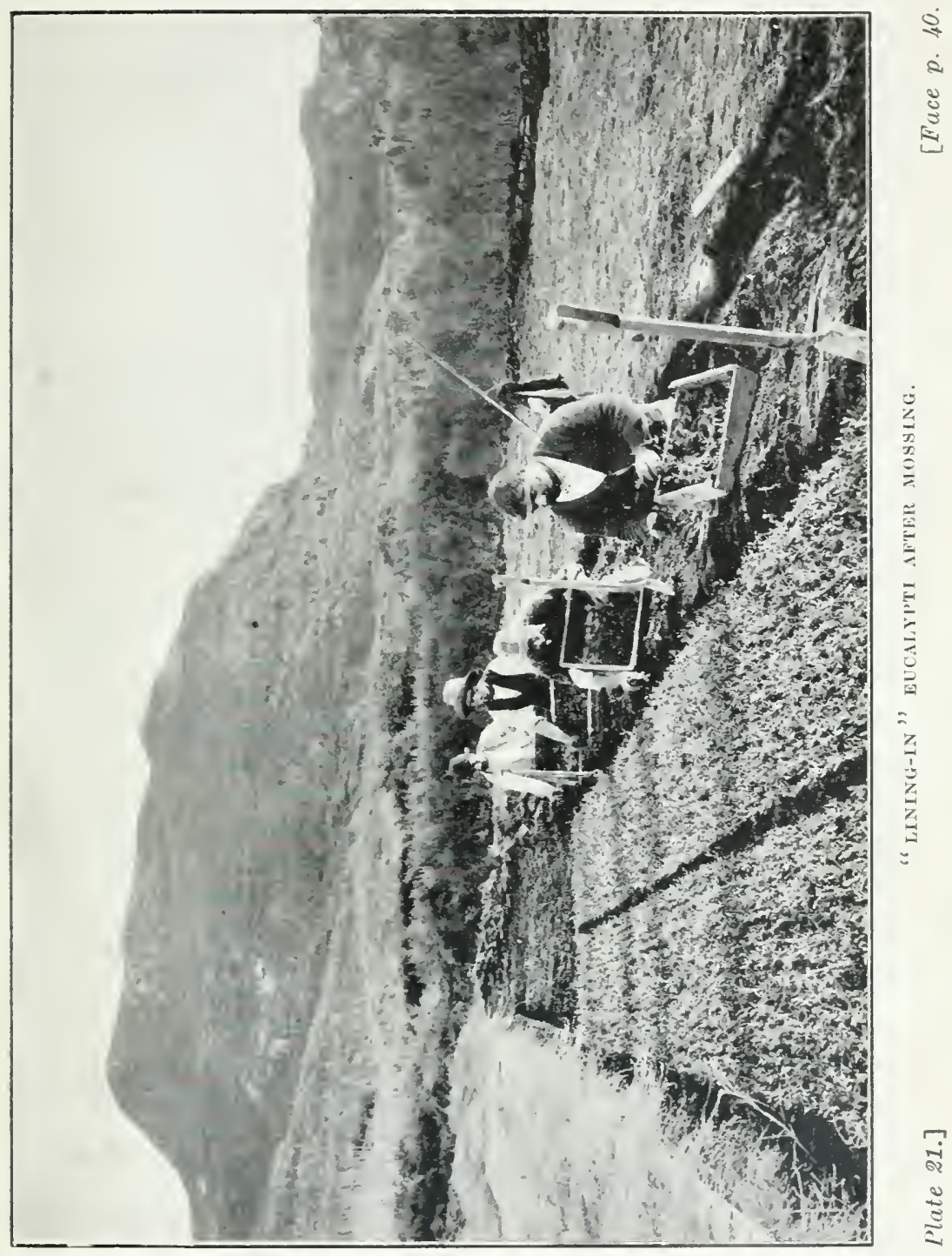



unless artificial plantatious are largely increased. But, even if no incidental revenue were to be looked for, a plantation of timberproducing trees possesses a commercial value as an addition to the landowner's capital. It possesses a value of the same character as a life-insurance policy upon which several pavments have been made: though the amount cannot be collected until an uncertain period in the future, it will nevertheless eventually bring its market value.

To most farmers the raising of a crop of trees from seed or from seedling-trees seems a long and hopeless undertaking. The period required for a tree to attain profitable size under favourable conditions is, however, much shorter than is generally supposed. In from ten to fifteen years from the time of planting, all the fuel and fencing-material necessary for farm use can be had for the cutting, without in any way interfering with, but, on the contrary, being an actual benefit to, the remaining trees.

As an instance of the comparatively rapid growth of the Englisi Larch on poor dry soil in Canterbury, it may be mentioned that a plantation was made seventeen years ago at $12 \mathrm{ft}$. apart-300 per acre. The land was worth $£ 2$ per acre, and the total cost of trees, fencing, and planting was $£ 12$ per acre. Very little attention was given during the seventeen years of growth, and $£ 1$ per acre would more than cover the expenditure incurred in that way. The total cost (including land) to the proprietor was therefore $£ 15$ per acre. At the present time each of these trees will yield two strainingposts $8 \mathrm{ft}$. long by an average diameter of $10 \mathrm{in}$, as well as four posts $6 \mathrm{it}$. long by $6 \mathrm{in}$. in diameter. Fencing-material of similar sizes cut from native bush could not be delivered on the property under $6 \mathrm{~s}$. each for strainers and $2 \mathrm{~s}$. each for posts, bringing the value of each tree to $£ 1$, less felling and crosscutting into lengths. Several trees cut down for fencing purposes cost $6 \mathrm{~d}$. for felling and $3 \mathrm{~d}$. per cut for crosscutting, and as the Larch makes only slender side branches the total cost of felling, crosscutting, and branching can be put down at $2 \mathrm{~s}$. per tree, leaving $18 \mathrm{~s}$. each as the value of each tree, or for the $300, £ 270$. Deducting the initial cost of $£ 12$, there remains a credit balance of $£ 258$ as a return for seventeen years' growth, and the land is in better condition now (through the humus formed by the annual fall of leaves) than it was at the start. Portion of this land adjoining the plantation is now let for grazing purposes at an aunual rental of 2 s. per acre, or $£ 113$ s. in seventeen years-the same period as the trees took to yield fencing-material as above mentioned. No other crop-whether grain-growing, mixed farming, stock-raising, fruit or vegetable growing-can compare with the above results, while at the same time not only has the soil been retained in a fertile condition, but it has been vastly improved in its productive capabilities.

Another reason often urged by farmers for not planting is that the trees harbour small birds and thus increase the loss arising from that source. This, again, is a mistake. The sparrow is rarely 
found nesting in trees far from buildings, and the green linnet nests in hedges and low bushes, sometimes also in young trees; but when trees attain any appreciable size no linnets' nests will be found in them. Let any one who thinks the trees will harbour birds visit some bit of native bush or fairly grown artificial plantation and he will find few, if any, sparrows or linnets within its borders. It is true that birds congregate in the evening in some favourite clump of trees for the purpose of roosting there, and will gather from long distances in districts where trees are sparse; but experience has shown that the fields near such roosting-places do not suffer more from the depredations of birds than those at a distance from them, and the number of birds in a district is not increased because of such clumps. It is the food-supply, not the roosting or nesting facilities, that regulates the number of birds in any locality. Where the birds so congregate to roost, facilities are afforded for their destruction in large numbers which are not at present made use of.

So far we have referred only to planting good arable land, but on many farms there are pieces of poor ground which are either too rough to plough or are otherwise unsuitable for cultivation, and on such pieces of ground trees are the only profitable crop that can be grown. If the ground be steep or rocky, trees can be found that will flourish there; or if it be low and swampy, other trees can be grown there : even on bare gravelly patches trees will grow. All such places on the farm should be so ntilised; but planting need not, and indeed should not, be confined to such plots. A farmer's first aim in planting should be to obtain shelter from the prevailing winds, and how that can best be attained must in every case depend on the configuration of the ground to be planted. For example, a farm with a general slope towards the south-west requires more planting to shelter it thoroughly from that direction than does one with a northerly aspect. In most cases shelter from the southwest and north-west is mainly desired, but often it is highly desirable that the north-easter should be excluded, or at least its force broken.

By planting some of the nut-producing trees-such as Walnut, Chestnut, Hickory-the farmer can insure an additional source of revenue from their produce many years before maturity has been attained, and the demand for such produce is always steadily increasing. He can also do so by planting Oaks, as even now in Canterbury acorns are marketable for feeding pigs.

Under natural conditions all trees reproduce themselves from seed, and in this way spaces caused by disease or accident are gradually filled up. If, however, stock are allowed to graze amongst trees-be they either small or large-Nature's provision for the protection of the plantation is cut off. By far the greater injury from stock results indirectly from the trainpling of the soil and the consequent destruction of the natural mulch about the trees, and of the vegetable mould, which is chiefly composed of decaying 


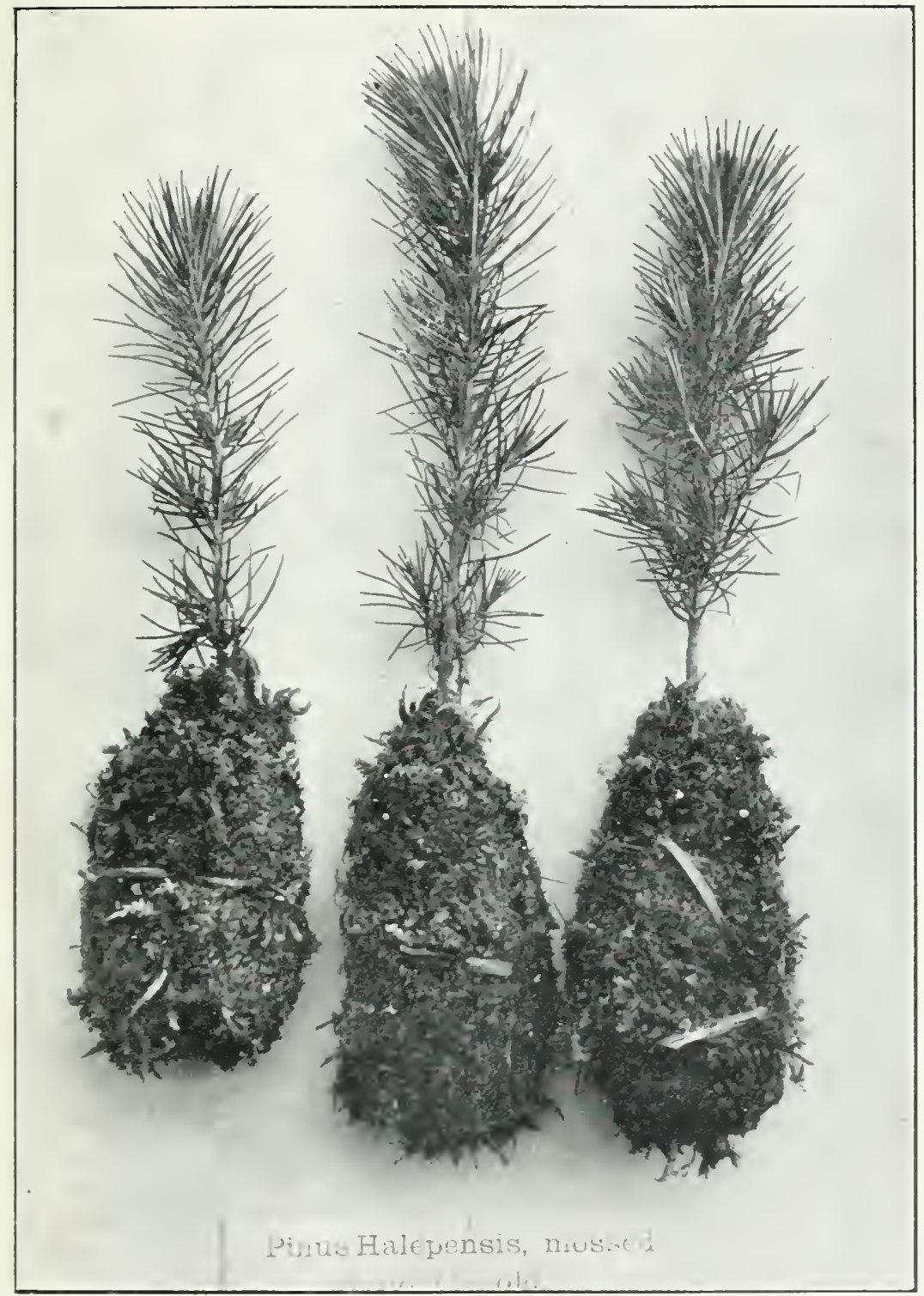

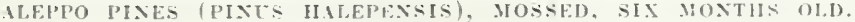

Illite 22.]

Fice p. f?. 

leaves and twigs. This mould is of a very porous nature, and forms a natural reservoir for water, from which moisture is given up slowly throughout the season, and the air about the trees is kept in that humid condition so favourable to plant-growth. The downward movement of water through the forest mould is also slow, and as the moisture sinks, the roots of the tree push downward through the softened subsoil. For this reason, forest-trees grown under natural conditions are deep-rooted, and are seldom blown down by high winds. In the pastured plantation, however, forest mould is absent, and the sharp hoofs of stock cut up and so consolidate the top soil that its water-holding capacity is practically destroyed. Rain falling upon pastured plantations finds no natural reservoir, but passes quickly through the soil, and when summer comes the soil is hard and cracked. Deep root-growth under such conditions is checked, and the trees are frequently blown over by strong winds; large trees which have resisted adverse conditions for years wither up and die, whilst such as manage to exist have a stunted and scrubby appearance. Another evil consequent on allowing animals to pasture among plantations is the entire absence of branches on the outskirts, through sheep and cattle eating, trampling, or brushing against the trees to a height within the reach of such animals. Want of dense growth at the base of trees forming the outer boundary produces a constant draught of air through the plantation, which is continually robbing the roots of moisture, and is not only doing the plantation injury, but prevents it fultilling its legitimate purpose of providing shelter to stock at the height it is most needed.

Few persons sufficiently realise the need of care and preparation in tree-planting. The universal idea is that all that is necessary is to dig a hole in the ground, put in the tree, and fill the hole up again. Tree-planting in this colony is too often conducted on these lines, no care being taken to prepare the ground or to see that the precautions which a skilled gardener or nurseryman would adopt are observed. Trees are frequently planted after they have been exposed to the sun and air until their roots are dry. Such trees have little chance of success, especially Pines or other coniferous trees, which are much more sensitive than ieciduous trees, such as Oak, Ash, or Sycamore. It is too commonly the case that the interest of the planter ceases with the planting, and the trees are leit to perish from absolute neglect.

Those interested in tree-planting should read a pamphlet entitled "Forestry in its Relation to the Farmer," by Robert McNab, Esq., M.A., M.H.R., published at the Southem Standard office, Gore, Otago. It consists of four short articles: "The Farmer's Homestead Plantation," "Forestry's Contribution to Agriculture," "Forestry's Aid to the Farm," and "Forestry Supplies." Mr. $\mathrm{McNab}$ deals with the various subjects in an up-to-date manner, and gives a vast amount of general information on the subject of tree-planting as the result of his own experience in the Gore district. The present writer cannot, however, agree with some of the methods 
advocated, nor with the assertions made. For instance, on page 14 it is stated, "I have no hesitation in saying that they (trees) are no more difficult to grow than are the turnips in the field." This may be so with certain classes of trees in a moist district such as Gore, pro vided one has the necessary knowledge to start with, but without some previous experience it is feared failure may often result. Planting under the circumstances mentioned by $\mathrm{Mr}$. McNab can no doubt be effected at a minimum of cost, but the results are doubtful, and the method of spacing and lining advocated by him could not be carried out on the steep or rough ground which it is often desirable to utilise by planting.

\section{CHAPTER XI.}

\section{RAISING PLANTATIONS BY DIRECT SOWING.}

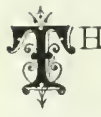

ERRE are many trees which succeed better when sown at once in their permanent positions in the plantation than when raised in nurseries to a certain stage and planted out. The cost of raising plantations by the former method is naturally much less than by the latter when the tree-seeds used are moderate in cost. Oak, Walnut, Hickory, and Chestnut should always be sown direct, as these trees produce exceedingly long tap-roots, which are liable to be destroyed or bruised during the operation of transplantation. There can be no question that trees raised by means of direct sowing have decided advantages over those raised in seed-beds and afterwards transplanted, more especially in the case of species which develop a deep root-system. On the other hand, many of the best and most profitable timber-trees have exceedingly small seeds, which are very expensive to purchase, are slow of growth during their first year or two, while they demand shade, moisture, and attention by way of weeding-operations that are only practicable under close cultivation in nursery-beds.

From one cause or another many minute seeds fail to germinate, blanks occur through too deep sowing or through winds blowing away the soil covering, frosts nip or kill tender species during the first winter, and birds are a constant and increasing source of annoyance, as they are responsible for serious loss through eating off the seedling plants as they germinate. As all failures must be replaced the following year, this is an item of expenditure to be set against the cost of establishing a plantation by direct sowing.

From what has been stated in regard to the high cost of seeds and the small percentage of successful germination it may be asserted that direct sowing is neither desirable, profitable, nor 


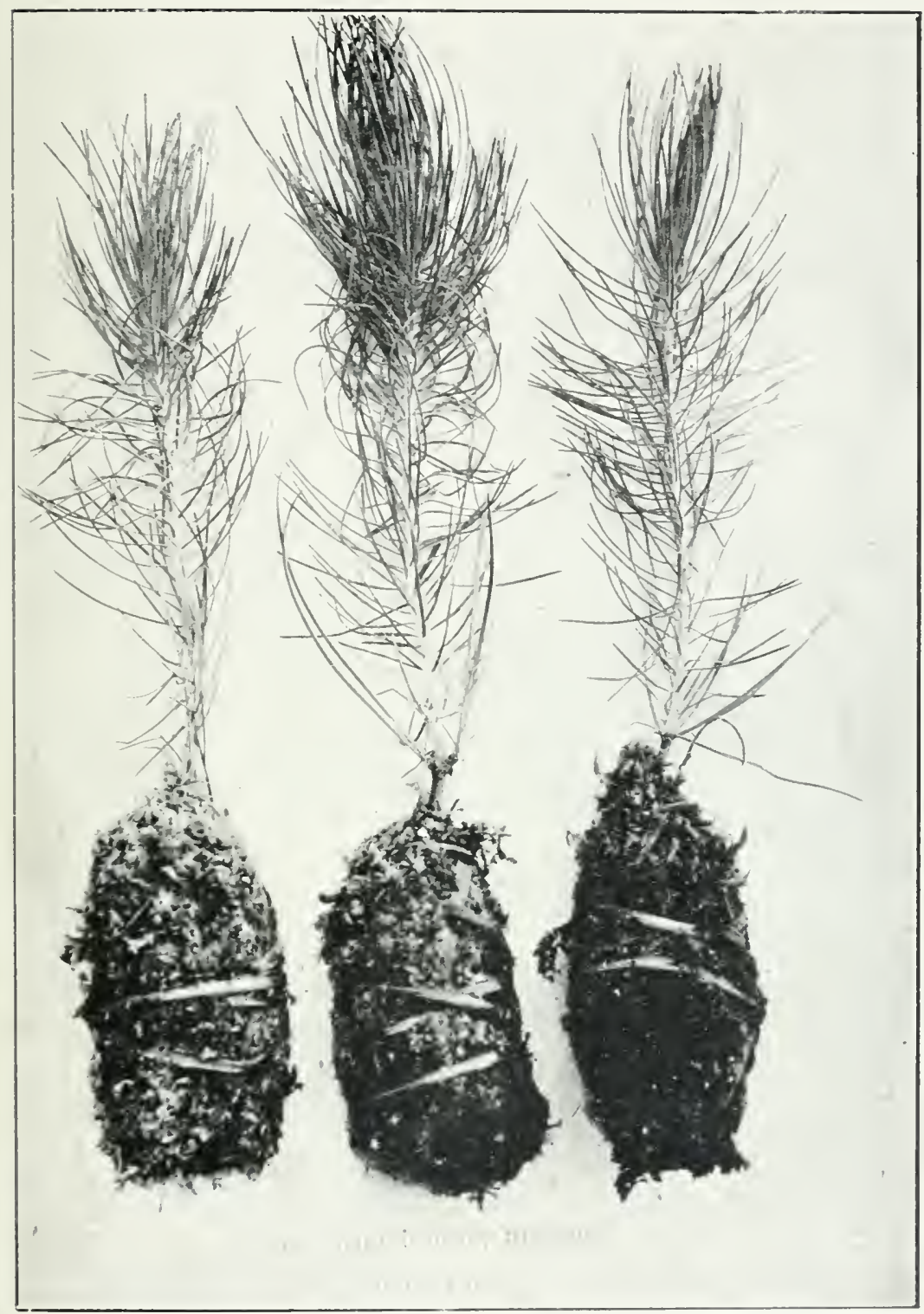

CINARY ISLAND PINES (PIXTS CANAIIFXSIS), MOSGED, SIX MONTIIS OLD. Plute 23.]

[Face p. 4.4. 

successful, except under special circumstances, and then only with certain large-seeded species, or trees that are fast-growing during their first year.

In sowing Acorns, Walnuts, Chestnuts, Sycamore, and other large seeds in situ the following method is adopted: A man with a pickmattock clears each spot intended for sowing of all grass and other growth for about a foot in diameter. If the ground is hard he uses the pick-end to loosen up the soil to the depth of five or six inches. Should the soil be of a free open nature no further preparation is required. A second man follows up with the seeds in a bag and armed with a stonemason's hammer, on one end of which is a short, flat-pointed pick. With this tool he makes the necessary opening, inserts the seed, and tramps the disturbed soil firm. The depth at which the seedis are sown varies according to size, the general rule being to sow at a deptl of double the diameter of the seed. The growth of young Oaks during the first year generally averages from 8 in. to $10 \mathrm{in.}$ Walnuts and Chestnuts $12 \mathrm{in}$., and Sycamores $10 \mathrm{in}$. to 15 in.

In order to minimise the risk of blanks occurring through using unsound seed, it is a good plan to test acoms, chestnuts, hickoryseeds, and walnuts in water every morning before commencing work. If these seeds are thrown into a bucket of water and those that float are removed, it will be found that only sound seeds remain in the bottom of the bucket. Sycamore-seed is generally of such good germinating quality and so cheaply collected that two seeds may be sown in the one spot, and the weaker plant can be pulled up the following year when renewing blanks. Seed-sowiug can be done in most places as soon as the seeds ripen in autumn, but in very frosty inland localities this work should be deferred until spring, in order to avoid the throwing-out of the seeds by frost-lifting.

Many Eucalypts and the three principal Acacias (or Wattles) nay also be raised with a fair amount of success by direct sowing. The following paper on this branch of the subject from the pen of my esteemed friend Mr. T. W. Adams, of Greendale, Canterbury, is well worthy of careful perusal by those who contemplate the laying-down of Eucalyptus plantations. Mr. Adams is perhaps the most successful amateur sylviculturist in this colony, and an immense amount of practical experimental work has been carried out by him in the way of introducing and testing the growth and general suitability of timber-trees from all quarters of the globe. He has also contributed during the last seventeen years a series of very valuable articles on treeculture to the Journal of the Canterbury Agricultural and Pastoral Association. These are well worthy of being reprinted in pamphlet form for the benefit of would-be planters-especially in Canterbury-to whom the results of his experiences would be invaluable. 


\title{
ON RAISING PLANTATIONS OF GUM-TREES.
}

\author{
[By T. W. Adans, Greendale.]
}

There are a great number of gum-trees known to botanists. Baron Mueller, in his splendid work, "Select Extra-tropical Plants," enumerates over seventy species. Of this large number there are very few that are quite hardy in Canterbury; those that have resisted the frost best at Greendale are Eucalyptus coriacea, E. coccifera, E. Gunni, E. Stuartiana, E. amygdalina, and E. urnigera. These six were but little damaged during the severe winter of 1899 . Others about as hardy as the Blue-gum were Eucalyptus regnans, E. macro. rhyncha, $E$. rostrata, $E$. crebra, and $E$. hemostoma. The following were all killed by the frost, namely: Eucalyptus acmenoides, E. botroyoides, E. capitellata, E. cornuta, $E$. rudis, $E$. corymbosa, $E$. gomphocephala, $E$. homiphlora, $E$. longifolia, E. Leumannii, E. maculata, E. megacarpa, E. obcordata, E. paniculata, E. pilularis, E. piperita, E. munctata, $E$. redunca, $E$. resinifera, E. resini. fera grandiflora, $E$. robusta, $E$. sideroxylon, $E$. siderophloia, $E$. Siebernana, $E$. stricta, and some others. Of those killed some resisted much better than others, and would bave passed through the winter most likely had they been nearer the sea.

It may be thought that the long list of those that were killed might very well have been left out, but as much may be learned sometimes from the failures of others as by their success. My object in naming them is to warn intending planters not to sow those that are not hardy. I should not have sown them, but the seed was sent to me, and I was glad to test them and to see whether there might not be a few more suitable for planting in Canterbury than we had yet been made acquainted with.

After thirty-five years' experience I have come to the conclusion that persons making plantations in the most favourable situations would do well to limit their selections to the first twelve species named, and generaily to the first six species as being more reliable than the others.

The seeds of all the hardy gums are small, and do not generally come up as well as those of the Blue-gum, nor do they start with the same vigour the first sear. Of the best way to make a new plantation it is very difficult to write. If it is virgin soil broken up from the tussock, and the seed being good, there need not be failure, but after land has been worked and there is sorrel-seed in the ground the difficulties are very great, as the weeds get possession before the trees. In the latter case I have found considerabie advantage in giving the gumseed a start by mixing it in sand made a little damp, sav, a fortnight before it was sown. This, of course, needs care, as if left a few days toolong the seed will be sprouting. Even then I would expect greater success than if sown dry. The laud, of course, should be kept worked up to the last day before sowing. The sowing may be done by an ordinary hand-drill, or, if the area is large, by a graindrill, by closing most of the spouts. Sown in rows about 2 yards apart, a crop of carrots or other roots may be raised between the rows very successfully, particularly if the land has just been ploughed six or seven inches deep out of grass, well turned over, and only the surface again worked. In sowing the gum-seed it is well to mix a little mustard-seed with it. The mustard-seed mus not be mixed with the gums until they are about to be sown. The mustardseed will quickly spring up, and show the exact row all through the summer. This is a great advantage in weeding the gums, as for a long time they are very puny and very likely to get choked by the weeds if left to themselves. Other things besides Gums may be sown in this way, as Cupressus macrocarpa, or any other of the Cypress family. The Pines, too, will germinate and come up well, but the small birds are very severe on the Pines, often taking the whole lot. The birds do not often interfere with the Cypress plants.

In sowing a plantation in this manner it is well to use plenty of seed. No harm will come of there being too many plants; if left it will be a case of the survival of the fittest, or they may very successfully be taken out the following spring to make a new plantation or extend the present one. The best time to sow will be about the 1st October, using about $80 z$. to the acre, and a little 


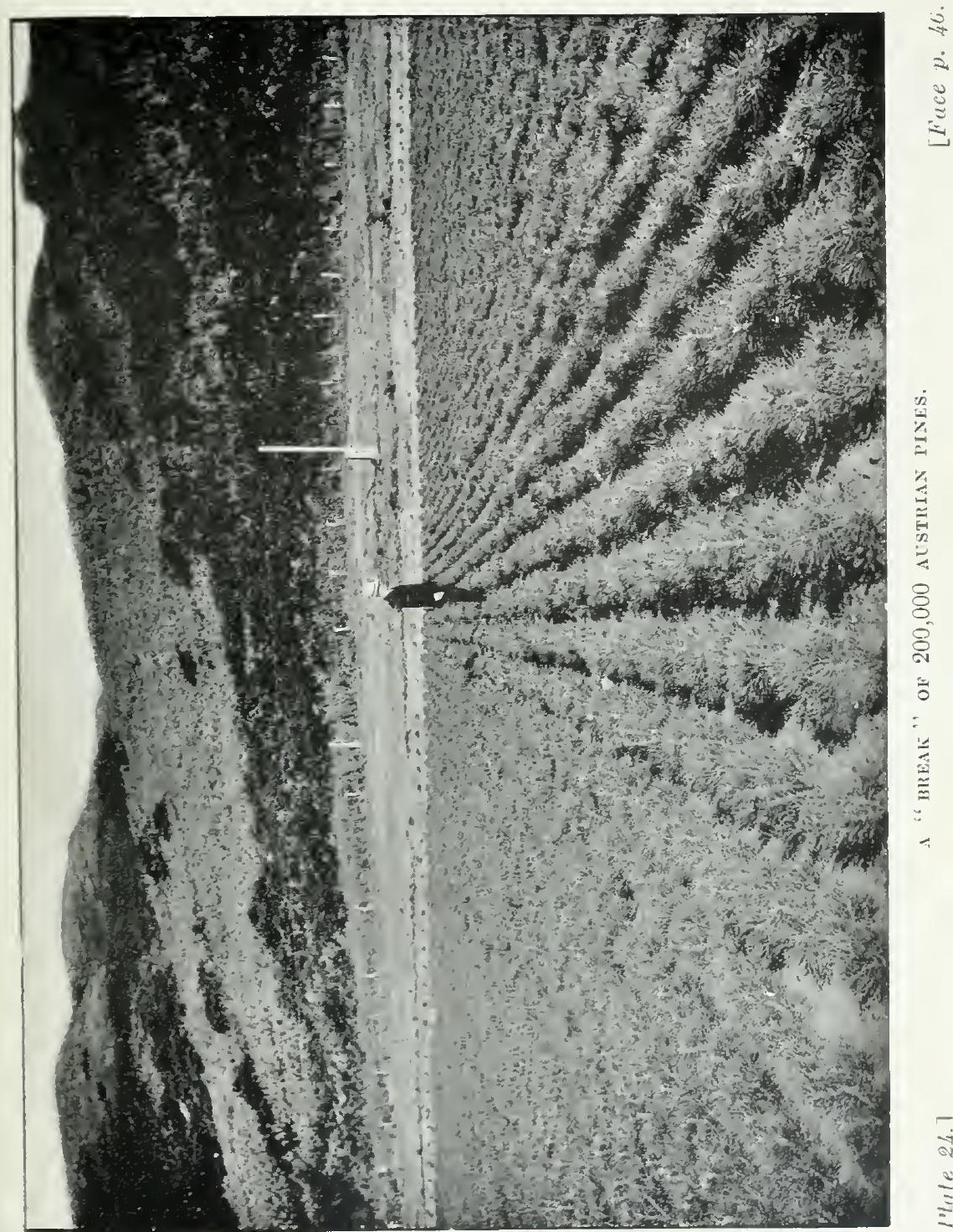



Beifast or Islington manure will add to the chances of success. Should it turn out after all that there are not suficient plants to form a good plantation, the gaps may be very successfully filled with Pines the following sprıng, adding greatly to the beanty and shelter of the plantation.

Of the six bardy Gums named above, Eucalyptus Stuartiana is the fastest grower. E. coriacea is the hardiest, and I almont think it grows slower than either of the others. $k$. Gunnii makes very rapid growth at first, but is not so remarkable for its growth after the first two years. It is almost as hardy as E coriacea. Onestriking characteristic of Gum-trees is the extraordinary differeice of the foliage in both shape and colour of young and old trees. Most people have noticed this in the Blue-gum, and it applies to all or nearly all of the others, except, perhaps, E. Rislonii and E. gumopnylla, which always retain their early form of leaf.

Of the uses of the wood of the different species of Gums there is not much need to speak; but I will add Baron Mueller's remarks on the speeies here recommended. Of $E$. amygilalna he sars it is a tree of the largest size. A tree was measured in the Cape Otway Ranges $415 \mathrm{ft}$. high and $15 \mathrm{ft}$. in diameter. The wood is easily split, well adapted for shingles, rails, staves, inner buildingmaterial, and many other purposes; but it is not a strong wood. Of E. Gunnii he says it atiains a considerable size, and supplies a strong, useful timber. $E$. coriacea is used for ordinary building and fencing purposes, and for quiekly producing fuel is one of the best of trees. Of $E$. Stuartiana he says the wood is mostly used for fencing and for fuel, and is of considerable strength. Nothing is said of the merit of the wood of $E$. coccifera or $E$. nmigera; but a friend of mine cut down a large tree of the last species a few years ago and found it of great value as fuel, almost equalling coal in its heat-producing qualities. In Canterbury $E$ umigera grows into a fine tree, and is more dense in its foliage than any other I bave noticed. In closing, I may add that the different species of Gums may be raised in boxes and planted out as other trees are, but they require sowing very late in the summer-say, the 1st December-or otherwise they will be too large to transplant succesifully.

\section{CHAPTER XII.}

\section{WATTLE PLANTATIONS.}

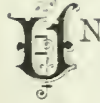

NDOUBTEDLY the cheapest method of raising a plantation for both shelter and firewood is to sow Wattle-seeds, either broadcast or in rows, where they are to remain. There are, however, many places where the Wattle will not succeed on account of frosts, such as central Otago and inland Canterbury, where sad havoc has been caused amongst those trees during the past few years. Within a few miles of the coast, in the southern portion of the South Island, any part of Nelson, Narlborough, and the North Island, except the high lands, for a radius of, say, fifty miles from Lake Taupo, the Wattle will flourish and supply a large quantity of good firing in a very short space of time. For the purposes of raising a quick shelter on very poor land in exposed positions, with a view to planting more valuable trees later on, no tree will give such good results as the Wattle.

Although Wattles succeed well on most soils, those of a stiff, moisture-retaining quality should be avoided. It is immaterial 
whether the quality be rich or poor so long as it is free, open, and dry. Where the land is ploughable it is advisable to prepare it by that method and harrow well to a fine tiltin. Soak the seed in almost boiling water for a few hours, and then keep it in a damp bag till fairly soft. Afterwards mix the seed well with sifted soil or sand, in the proportion of $8 \mathrm{oz}$. seed (dry) to a bucket of soil. The soil is merely to increase bulk for the purpose of sowing evenly, and the above quantity is sufficient for half an acre. After sowing, sufficient covering will be effected by giving the land one turn with the Cambridge roller, or, better still, run a flock of sheep on the land.

Another method of inducing speedy germination, frequently practised in Australia, is to collect a quantity of brushwood and burn it in a heap. When the flames have become extinguished throw on the wattle-seed and turn the heap of smouldering ashes over to thoroughly mix the seed amongst it, and let it remain until cooled down, when the seed will be ready for sowing, and germina. tion will take place in a few days. For convenience in sowing the whole should be passed through a $\frac{1}{2}$ in. sieve.

Instances are on record of wattle-seed remaining dormant in the ground for many years. A piece of land was ploughed at Rega, in New South Wales, which had been cleared of Wattles thirty-seven years previously, and shortly after ploughing was completed they germinated thickly all over the ground.

When the land is too steep or uneven for ploughing, spots can be selected every few feet and well loosened up with the spade. Into the centre of each spot one or two seeds can be dropped; but a good firm bed should first be made for these by simply stamping the heel into the centre and afterwards covering the seeds with a handful of soil. Early spring will be found the best season for successful results.

All varieties of Wattles are very impatient of transplanting unless the greatest care is taken during the operation. Where it is found inconvenient to sow the seeds where the trees are to remain, probably the best plan is to use $3 \mathrm{in}$. flower-pots, in which two or three seeds can be placed, and should more than one germinate the strongest can be left. When the roots show through the hole in the bottom of the pots it will be time to transplant them to their permanent homes. To take them out of the pots turn them upside down and hold the fingers across the mouth, tap the lip of the pot on some solid substance, and the ball of roots will come out intact. After the young trees are well above the ground they should be gone over and thinned to from $4 \mathrm{ft}$. to $8 \mathrm{ft}$. apart by pulling up the weak and leaving the more promising plants. Beyond going over the young trees occasionally to remove side branches, in order to direct the growth into one stem as much as possible, and keeping down weeds, no further attention will be required.

Acacia dealbata (Silver-wattle), A. pyracantha (Broad-leaved 


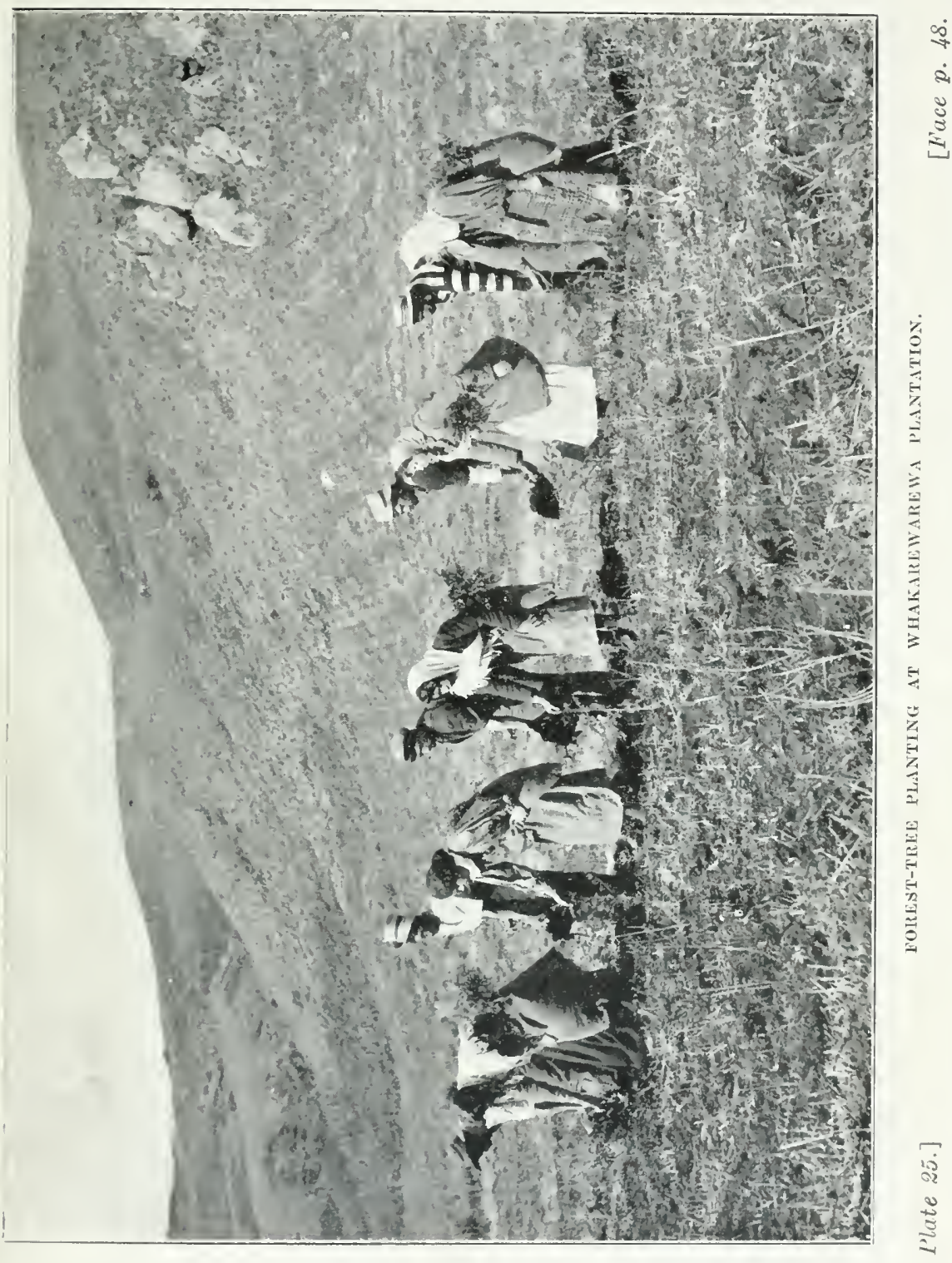



Wattle), A. decurrens (Black-wattle), and A. melanoxylon (Blackwood) are the varieties recommended for general planting.

The following are particnlars regarding the four principal Wattle-trees:-

Acacia dealbata (Silver-wattle).-This is the hardiest of the four species under notice. It is a native of Tasmania, Tictoria, and New South Wales, and, contrary to the geueral opinion, frequently grows to $150 \mathrm{ft}$. in height. Instances are recoried of its having attained a girth of over $11 \mathrm{ft}$. In Auckland a four-year-old tree, grown on good soil and in a sheltered locality, measured $35 \mathrm{ft}$. in height. It is a very ornamental tree for the first few years, but later on becomes of rather straggly growth. The timber is excellent firewood. This species should only be planted on land unfit for anything else, as it throws up suckers from the roots, which are difficult to eradicate. This tree is distinguished from the Blackwattle by the silvery hue of its roung foliage; it Howers before the Black-wattle, and ripens its seeds about six months after flowering.

Acacia decurrens (Black or sometimes called Green Wattle) is a native of southern Queensland, New South Wales, and portions of Victoria. It is not hardy in Canterbury, Otago, or Southland except within a few miles of the coast. It grows exceedingly fast in moist warm localities on the poorest of soils, seldom reaches more than $50 \mathrm{ft}$. in height, makes excellent shelter, is easily and cheaply raised, and is one of the best of firewoods. Unlike the Silverwattle, this species seldom or never throws up suckers. The seeds in a pound weight average from thirty to forty thousand grains. The flowers are similar to those of the Silver-wattle, but they are much later in coming into bloom, while the seeds do not mature for twelve months or more.

Acacia pyracantha (Golden or Broad-leaved Wattle).-This is the richest of all tannin-producing trees. It is of rapid growth, does well on poor soils, but never attains more than $20 \mathrm{ft}$. or $25 \mathrm{ft}$. in height; found chiefly in South Australia, and is less hardy than the others mentioned. In the seedling stage this species produces pinnate leaves, which are soon replaced by flat entire leaves or phyllodes, resembling some species of Eucalyptus. Being of a shrubby growth, it is invaluable as shelter or as a nurse to more valuable trees. In moderately cold localities this and other somewhat tender trees may be successfully grown on lands with a western aspect, so that the sun will not shine on them early after severe frost. A pound of seeds contains from twenty to twenty-four thousand grains.

Acacia melanoxylon (Blackwood) is indigenous to the cooler parts of Australia and Tasmania, and grows frequently to $80 \mathrm{ft}$. in deep light soils. It produces immense boles, from which very fine, dark, heavy, beautifully grained timber is cut-frequently $4 \mathrm{ft}$. to $5 \mathrm{ft}$. in width. The timber is one of the best for bending under steam, besides being suitable for shop-fittings, furniture, billiard-tables, \&c. This species requires deep soil with a cool moist bottom to do 
well. It is probably the hardiest of the large-growing Acacias, and one that should be largely planted in this colony.

Plate 27 illustrates a successful method adopted with this and other species of trees which are difficult to transplant. Plants 4 in. to 5 in. high are lifted from the seed-beds and wrapped in fresh sphagnum moss with a little soil in the centre. The moss keeps the roots constantly moist, and within a few weeks after mossing fresh roots will be found coming through the sphagnum in all direetions.

.0丁3я

In addition to the species enumerated, there are many others worthy of cultivation, and further information on the subject may be found in "Wattles and Wattle-barks," by Mr. J. H. Maiden, F.L.S., Sydner. It may be mentioned that there are 312 species of Wattle in Australia, over a hundred of which are found in New South Wales.

Wattle-growing is carried on extensively near Auckland by the Government of New Zealand, and Mr. E. Clifton, Superintendent of the Governinent Experimental Station at Waerenga, near Auckland, kindly supplies the following information on the formation of Wattle plantations:-

The usual procedure in forming a Wattle plantation is to fell and clear the scrub, plougn, and work down roughly with disc-harrows, and sow during the montb of October. Scald the seed, and sow at the rate of $1 \mathrm{lb}$. per acre. A great advance on this is to drill in $\underset{\ddagger}{4} \mathrm{lb}$. seed with $1 \mathrm{cwt}$. of bonedust. Trees so treated are at two years equal to those of four years sown without manure.

The cost of Wattle-sowing may be estimated as follows: Clearing and burning, per acre, Ts. 6d. ; ploughing, is. 6d. ; disc-harrowing, one stroke, 1s. 3d.; sowing, 9d. ; seed, 1 lb., 2s. ; harrowing (tine or chain), 1s. : total, £1. To this with advantage may be added-a second ploughing, at $6 \mathrm{~s}$. per acre, $6 \mathrm{~s}$.; bonedust, $1 \frac{1}{2}$ cwt., at $£ 510$ s. per ton, 8 s. 3 d. : total, 14 s. 3 d.

The returns may be estimated at-

Per acre, 10 tons green bark $=5$ tons dry, at $£ 515$ s. per ton.

$$
\text { f s. d. }
$$$$
£ \text { s. d. }
$$$$
2815 \quad 0
$$

Expenses-

Stripping 10 tons, at $£ 1$ per ton ..

Weighing, carting, and storing 10 tons, at 2s. $6 \mathrm{~d}$.

$$
\text { ‥ }
$$

Railage, about 5 s. on 5 tons

\begin{tabular}{lllll}
$\cdots$ & $\cdots$ & 1 & 5 & 0 \\
$\cdots$ & $\cdots$ & 1 & 5 & 0 \\
\hline
\end{tabular}

$1210 \quad 0$

From this has to be deducted rent, interest, \&c.

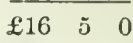

Wattle - growing for the production of tannin-bark occupies an area of 4,500 acres in this district.

The Black-wattle (Acacia decurrens) is now the only variety planted. The Golden-wattle (A. pyracantha), although yielding a larger percentage of tannin, does not form a fair-sized tree; also, from its bushy habit of growth, it costs more to strip than Black-wattle. The tbird variety $(A$. dealbata) forms a large part of the earlier-formed plantations, and is comparatively worthless. Its introduction was a misfortune.

At present IVattle plantations are not being appreciably extended. The price of bark in bundles has fallen from $£ 12$ to $£ 515 \mathrm{~s}$ per ton, and as about nine vears elapse before any considerable return is obtained extensive areas in Wattle are not popular with settlers. As regards soil, the Wattle appreciates a good 


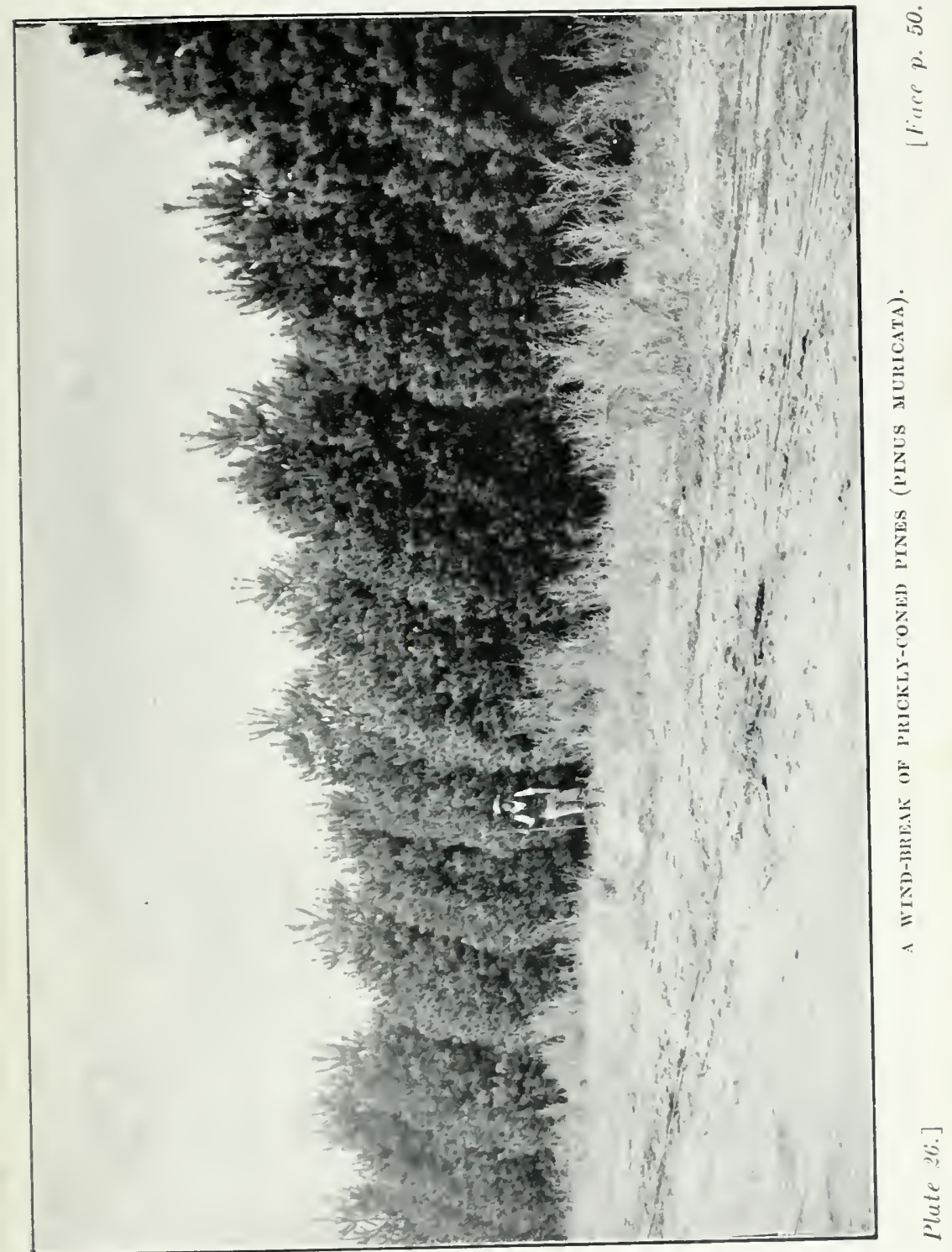



soil, but grows well on a roor one, its one requisite being good drainage. It will therefore succeed on anv land where the subsoil is fairly porous. Plantations should be laid out so that fire breaks can be easily maintained, for by this means a very probable loss and inevitable anxiety will be avoided.

In the year 189: 124 tons of ground Black-wattle bark from the Govern. ment Experimental Station, Waerenga, was sold at $£ 715 \mathrm{~s}$ per ton-a price that I believe had not previonsly been approached for New Zealand Wattle-bark. There was also on hat d a small quantity of Silver-wattle bark, for which there was very little demand, as the percentage of tannin is very low, being only some 16 per cent, as againsi nearly 30 per cent. for the former.

\section{CHAP'TER XIII.}

\section{HEDGES AND HEDGE-PLANTS.}

हले $\mathrm{E}$ advantages gained by the presence of live hedges around steadings and cultivated fields, judging from their absence on most properties, do not seem to be understood by the majority of landholders in this colony. In fields surrounded by good well-kept hedges grass and other crops mature much earlier than they do without such protection; cold winds are sifted and their force broken by striking against them. Better far, however, to have no hedges if proper attention cannot be given them. In most districts one finds hedges neglected, and in many parts extensive gaps made up with stakes and wire; others, again, have been allowed to run wild, taking up as much as $12 \mathrm{ft}$. in wiath of the field they occupy. A well-managed and properly formed hedge should not occupy more than $30 \mathrm{in}$. in width if the annual trimming and cleaning has been properly attender to. The worst place for a hedge is next to a plantation, unless the trees be planted sufficiently far away to prevent them growing over and smothering it. No doubt the expenditure incurred in fencing off a hedge from stock for the first few years has prevented many settlers from improving their properties by these most desirable adjuncts.

In no line of planting will there be found so great a variety of opinions with regard to the kind of trees or shrubs that should be planted, and to the time and manner of planting, as we find with respect to hedges. Perhaps every variety recommended might be entitled to preference in particular localities, and it is certain that none have a general adaptation to all parts of the colony. It is therefore necessary to consider the condition of a given locality, or to experiment in a small way with several kinds, and the result, may lead to a widespread benefit. It is to be hoped that the practice of planting a huge forest-tree like Cupressus macrocarpa and attempting to maintain it as a dwarf hedge-plant will soon cease. Past experience has proved that it is impossible to expect a monarch of the forest to alter its habits sufficiently to continue healthy and vigorous under the restricted conditions to which this 
tree is frequently subjected. Can there be any wonder that so many complaints have been made as to the dying-out of individual plants in hedge-rows when a moment's reflection will show the cause to be sufficiently obvious?

Before presenting a list of suitable shrubs for hedge-planting a few words may be said regarding the preparation of the land for their reception. The ground where a hedge is to be planted should be free from stagnant water, and should be trenched to a depth of $2 \mathrm{ft}$. by about $3 \mathrm{ft}$. in width. If the soil is poor or shallow in places it should be removed, and replaced with more fertile soil from the adjacent surface or elsewhere, so as to make the whole line as equal in quality as possible, and by this means secure uniformity in growth. The distance from plant to plant can only be given approximately, as this depends so much on the size at planting, rate of growth, and variety dealt with. All hedge-plants can be transplanted at any time from the fall of the leaf until the buds begin to swell in spring. Inland, where frost puts a stop to planting operations during the dead of winter, perhaps early autumn will be found the most suitable season to accomplish this work with the best results.

\section{List of Hedge-plants.}

Berberis Damini.--Makes a good dwarf evergreen hedge for small gardens; requires clipping-in closely twice annually. The blue berries are freely produced on quite small plants. These should be collected as soon as ripe and mixed with damp sand, which should be occasionally turned over to assist in separating the fleshy portion of the berry from the seeds. Sow in spring in spadewide drills, and cover with branches of Spruce or Manuka until the seeds germinate.

Berberis aristata (evergreen), irequently erroneously called Berberis vulgaris (a deciduous species).-This shrub will serve the double purpose of providing shelter and an inpenetrable fence for stock; it will grow in almost any part of the colony, and on any soil that is not stagnant. Fires may run through it, but it will sprout again with renewed vigour. It is the best all-round hedgeplant for farmers we have.

Berberis vulgaris. - This fast-growing deciduous shrub soon forms an impenetrable hedge on almost any soil and in any situation. There are numerous varieties of this species, all of which make very attractive shrubs on account of their beautiful autumn foliage and highly coloured berries, which range from white to black, pink to scarlet, as well as yellow and purple. Raised from seed treated in the same manner as $B$. Darwinit.

Holly.-One of the best plants known for the southern portion of the colony on heavy, damp land. In light land and in dry climates it is, however, attacked by scale and fungoid growths. The berries require "rotting" in damp sand for twelve months before sowing. As frost induces germination, the seeds (along with the sand) should be sown during late autumn in spade-wide drills. 


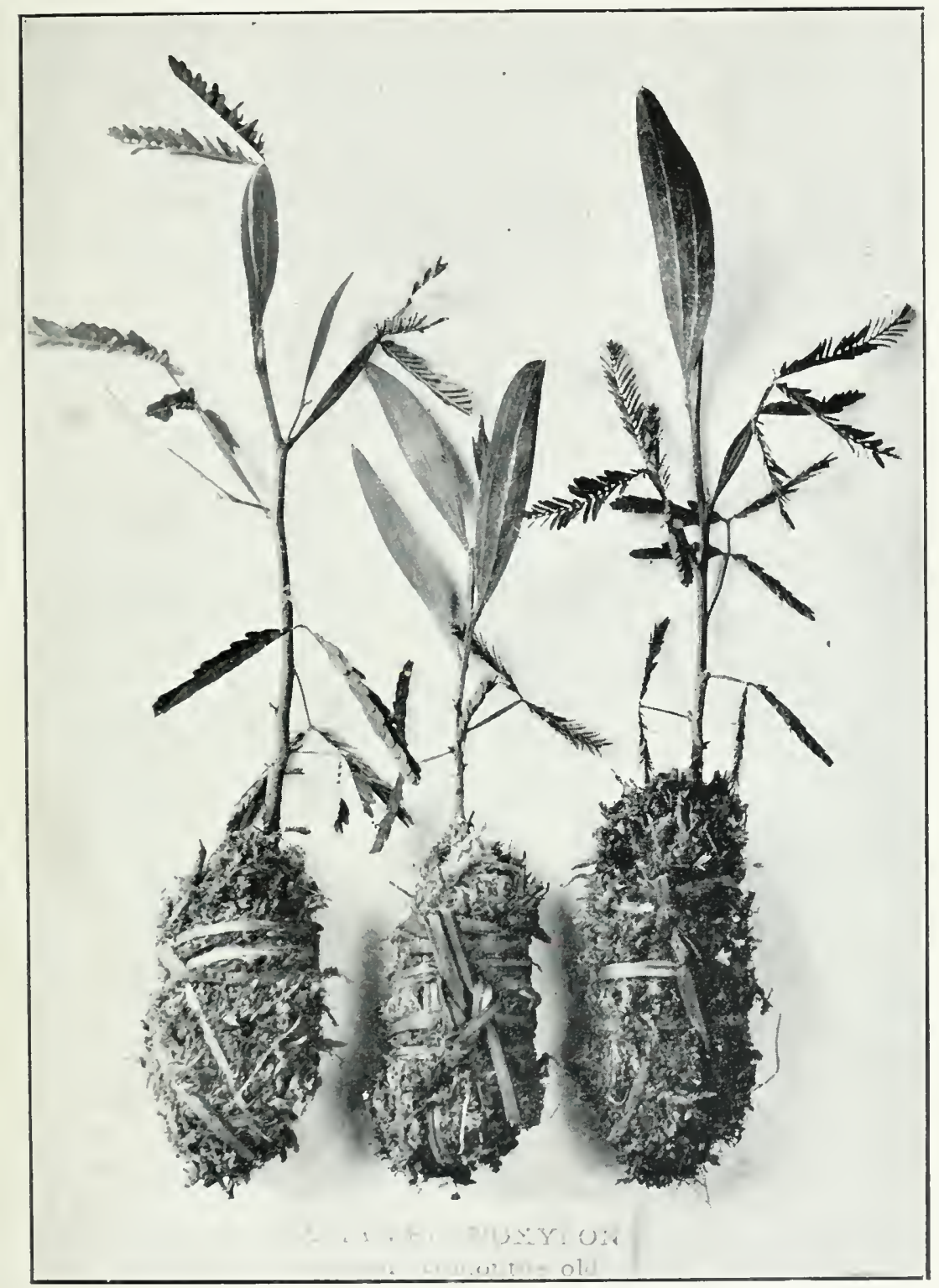

TASMA:IAN HAACKWOOD (ACACIA MELAXOXYLON) SEEHTINGS, MOSSED. Plute 2r. J

[Fure p. 52. 

The holly requires two years in the seed-beds before attaining sufficient size for transplanting into nursery-rows, where the young seedlings should remain for two seasons. Care should be taken that dead leaves are not allowed to collect in the heart of holly hedges, as owing to their inflammable nature there is a danger of fire destroving the growth of a lifetime.

Laurel, Common.-Fast-growing, and not particular as to soil or aspect; requires plenty of room and frequent cutting to make a close hedge. Owing to the poisonous nature of its leaves, laurel should only be planted in situations where stock are excluded. Easily raised, either from seeds or cuttings. The former should be placed in damp sand for the winter to rot the fleshy covering, and sown in early spring. Cuttings, about $15 \mathrm{in}$. long, taken with a "heel" of the old wood in March or April, will strike readily if planted thickly in a moist, shady spot. A little sharp sand put in the bottom of the trench while planting will assist in rootproduction.

Chamacypars Lawsuniana (known as Cupressus Lawsoniana).Makes a capital hedge, and stands clipping well; does well in any soil, if not too diry or wet. Seeds of this tree are freely produced in the colony. The small cones should be gathered just as they are opening (in April or May) and laid on a sheet placed in the sun until the seeds fall out. The whole should then be put into a fine sieve of a size that will just allow the seeds to go through but will retaiu the empty cones. Sow and cover very thinly, and allow the plants to remain in the seed-beds two seasons before transplanting. Directions as to method of sowing will be found under "Seedsowing."

Cupressus macrocarpa.-Suitable only for large-growing screens in deep soil near the coast; dies out when kept dwarf by constant cutting, and is a very bad neighbour to plants in close proximity owing to its soil-robbing properties. Seeds of this tree are obtainable almost anywhere in New Zealand. The cones of the current season do not ripen for twelve months, so that in collecting them those on the extreme points of the branches should be left. There is some difficulty in extracting the seeds during winter for spring sowing unless the cones are put under sash-lights exposed to the sun. Another method is to tie the cones up in small bags and hang them in a dry $\mathrm{l}$ ft or against a chimney for a few weeks, when most of the seeds will have fallen out. Any that are then left in the cones can be beaten out if put into a sack and well threshed with a stout rod, meanwhile changing the position of the bag at every stroke. For directions for sowing, see " Seed-sowing."

Coprosma Baueriana (Taupata).-Also a first-class ledge-plant for withstanding the sea-breeze; it grows quickly, and is easily transplanted, but is not suitable for the southern or inland portions of the colony on account of its susceptibility to frost. The shrub can be raised by cuttings put in during March or April in a cool moist spot. It is, however, much more readily grown from seeds, 
which are freely produced. Mix the berries in damp sand for the winter, and rub them through the liands or a sieve to separate the seeds. Sow in spade-wide drills in early spring.

Cratagus oxyacantha (Hawthorn, or Whitethorn).--One of the best all-round hedge-plants for the farmer, but unfortunately it has of late years been much affected by a disease commonly called "silver blight." This "silver blight" seems to affect seedlings much more readily than old plants in hedges. Couutless remedies for this and other diseases affecting trees and shrubs are available, but the writer's experience is that the best and cheapest course to adopt when disease atracks trees or shrubs is "burning." The immense variety of hedge-plants available admits of the selection of such species as are not liable to insect or fungoid pests. Haws can be collected in autumn, and mixed with soil or sand for twelve months before sowing in May or June. An occasional turn will hasten the rotting of the fleshy portion.

Escallonia macrantha.-A well-known flowering-shrub, with dark-green glossy leaves and bright-red Howers. It makes a dense and compact hedge, especially in coastal districts, even close to highwater mark. In order to maintain density it should be cut twice a year-during January, and again when the second growth is complete. Increasing by layers will be found the most economical method of propagation, as cuttings are not always entirely successful unless put in at the exact time-viz., when the first growth
has ripened. "Layering" may be described as simply the bending-
down of a lower branch in contact down of a lower branch in contact with the soil and cutting the under-side of the branch half through in a slanting direction so as to make a cut two or three inches long. Some clean sharp sand should then be mixed with fresh soil and heaped around the halfsevered portion, and a brick or stone placed on top to prevent disturbance. The point of the branch should be cut off short to prevent its being swayed about with the wind. Layering should be done in autumn, and the plants will be sufficiently rooted for removal within twelve months. Almost any tree or shrub can be increased by layering, but this system is only resorted to when propagation by seeds or cuttings is impracticable.

Elaagnus nmbellata ( $E$. japonica). - This is an excellent hedgeplant for all warm light soils. It grows with amazing rapidity, and is easily increased by cuttings during autumn. In many portions of the North Island cuttings are put in where the hedge is required, and within three years sufficient growth is generally made to keep out stock. Owing to its rapid growth and its tendency to become straggly, at least three trimmings during the year will be necessary to keep it thick and within bounds. Being a native of northern Japan it is fairly hardy, except in inland Canterbury and Otago.

Griselinia littoralis (Broadleaf).-There are few native trees more suitable for a hedge-plant than the Broadleaf, and few more easily raised from seeds or cuttings. When the seed turns black it will be fit for gathering and putting into sand, which should be kept constantly moist during the winter, and the seeds should be sown in 


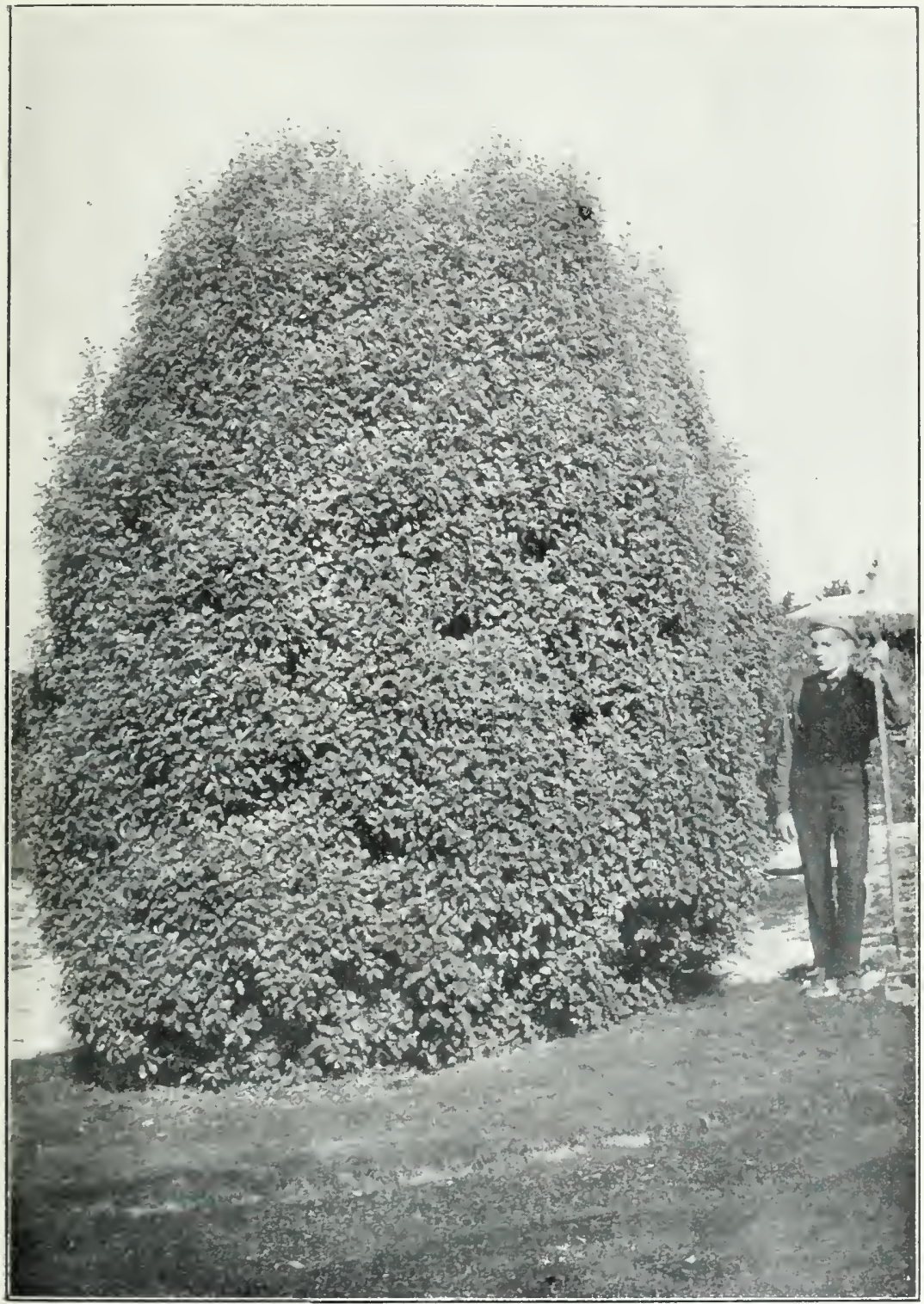

GOLDES AKE-IFE (OLEARIA FOSTERII), I GOOD SIFITEIR-SIHRIJ

Inte 28.]

[Face 1.5.4. 

early spring. Any ordinary soil suits it, but the seed-beds must be shaded and sheltered and kept constantly moist until the plants are through the ground. Being of rather slow growth during the first season, it may be found necessary to give the seedlings two years in the beds before lining them out in nursery-rows. Plant from $18 \mathrm{in}$. to $24 \mathrm{in}$. apart, and keep closely trimmed for the first few years, to produce a dense growth towards the base.

Lycium Afrum (African Box, or Kaffir "Thorn).--Almost evergreen, intensely spiny, of quick growth, stands clipping, and seeds freely. It can be easily raised from seed if mixed with sand for a month or two previous to sowing. Being somewhat tender in regions far from the sea, it is not suitable for inland districts, but does well on all dry or sandy lands-even on pure sand. Undoubtedly the best hedge-plant for coastal situations.

Liqustrum vulgare (Common Privet) and Ligustrum Japonicum (Japanese Privet).-Both excellent hedge-plants. The flowers are white and the berries black. For growing under the drip or in shade of trees few shrubs succeed better. Seeds collected in autumn and mixed with ciamp sand will germinate freely if sown during September. Both species can also be struck from cuttings put in sandy loam. The Japanese Privet makes a valuable ornamental and fast-growing shelter-tree if given plenty of space for development. Any soil or situation is suitable for Privet.

Olearna Traversin (Silver Akeake). - This is a native of the Chatham Islands, and one of the best hedge-plants for standing near the coast. Inland it becomes a poor, scrubby, nearly leafless shrub. It is very fast-growing, and stands clipping well. It can be easily raised from cuttings taken off about March and placed in sandy soil with some shelter. It requires frequent trimming to make a compact, dense hedge.

Olearia Forsterii (Shawi paniculata), (Golden Akeake), (see Plate 28).-This is one of our best ornamental hedge-shrubs, and at the same time equally valuable as a specimen or for shelter purposes. It will grow in almost any soil if not wet, endures extreine frost, is fast-growing, stands clipping, and is easily increased by cuttings. The latter should be taken off (from February to April) about $12 \mathrm{in.} \mathrm{long,} \mathrm{and} \mathrm{planted} \mathrm{closely} \mathrm{in} \mathrm{moist} \mathrm{sandy} \mathrm{soil} \mathrm{partially}$ shaded from the midday sun. The general rule in planting all cuttings is to put them two-thirds into the ground and one-third out. Firm tramping, and sharp sand at the base of the cuttings, also tend to induce root-formation.

Pittosporum.- Some seventeen species and numberless varieties of these trees or shrubs are natives of New Kealand. Probably the best for hedges is a variety of $P$. tenuifolium known in the trade as Pitrosporum Buchananii, which is found along the south-east coast from Green Island to the Bluff. It is an extremely fast-growing variety, and at the same time hardy. The seed of most species ripens in autumn, and should be gathered at once and rubbed through a sieve in order to separate the sticky seed from the capsule, otherwise half a dozen or more plants will germinate from 
each seed-vessel. Seeds of Pittosporum, and indeed nearly all native tree and shrub seeds, should be sown directly they are gathered, or be kept in moist sand, as if kept for a few months in a dry state before sowing the harder-shelled kinds will not germinate until the following season, while small seeds (especially those kinds belonging to the natural order of composites) lose their germinating qualities very quickly.

Pittosporums of most species can be sown where they are intended to remain, and by this system a better and quicker growth is made than if sown in nurseries and afterwards transplanted. The only objection to direct sowing is that a much larger area of land requires keeping in order than would be necessary if sown in the nursery. In direct sowing the seeds can be put in on the surface of the ground, about three or four to every foot; then walk along the top of the line, keeping the feet close together, and tramp them in firmly, afterwards drawing and shoving alternately a little soil with the rake from either side into the hollow caused by tramp. ling. Should the seeds germinate too thickly the plants can be thinned out to about 12 in. apart. When sown in spade-wide drills in the nursery ample room should be left on either side of the drill to allow of severe "wrenching" (as explained elsewhere), otherwise it will be impossible to transplant them successfully, owing to want of fibre on the long, straight tap-root. One season in the seed-beds will be sufficient to grow them large enough for transplanting into nursery-lines, and a month or six weeks prior to lifting for permanent planting they should again be thoroughly "wrenched" on four sides. The following species are recommended for hedges and general planting: Pittosporum Buchananii, P. Colensoi, P. crassifolium, P. Engenioides, P. fasciculatum, P. Ralphii, and P. tennifolium.

TABLEs showing the Number of Plants required to Plant an Acre of Ground, from $3 \mathrm{in}$. to $30 \mathrm{ft}$., Plant from Plant; also, a Mile in Length, from $3 \mathrm{in}$. to $100 \mathrm{ft}$. apart:-

PER ACre.

\begin{tabular}{l|c|c|c|c|c}
\hline Distance. & $\begin{array}{c}\text { Number per } \\
\text { Acre. }\end{array}$ & Distance. & $\begin{array}{c}\text { Number per } \\
\text { Acre. }\end{array}$ & Distauce. & $\begin{array}{c}\text { Number per } \\
\text { Acre. }\end{array}$ \\
\hline & & Ft. & & & \\
Ft. & 48 & 14 & 222 & $5 \mathrm{~F}$. & 1,742 \\
28 & 55 & 13 & 257 & $4 \frac{1}{2}$ & 2,151 \\
26 & 64 & 12 & 302 & 4 & 2,722 \\
24 & 75 & 11 & 360 & $3 \frac{1}{2}$ & 3,556 \\
22 & 90 & 10 & 435 & 3 & 4,840 \\
20 & 100 & 9 & 537 & $2 \frac{1}{2}$ & 6,970 \\
19 & 120 & 8 & 680 & 2 & 10,890 \\
18 & 134 & 7 & 889 & $1 \frac{1}{2}$ & 19,360 \\
17 & 150 & $6 \frac{1}{2}$ & 1,031 & 1 & 43,500 \\
16 & 169 & 6 & 1,210 & $0 \frac{1}{2}$ & 174,240 \\
15 & 193 & $5 \frac{1}{2}$ & 1,440 & 0 & 696,960 \\
& & & & & \\
\hline
\end{tabular}




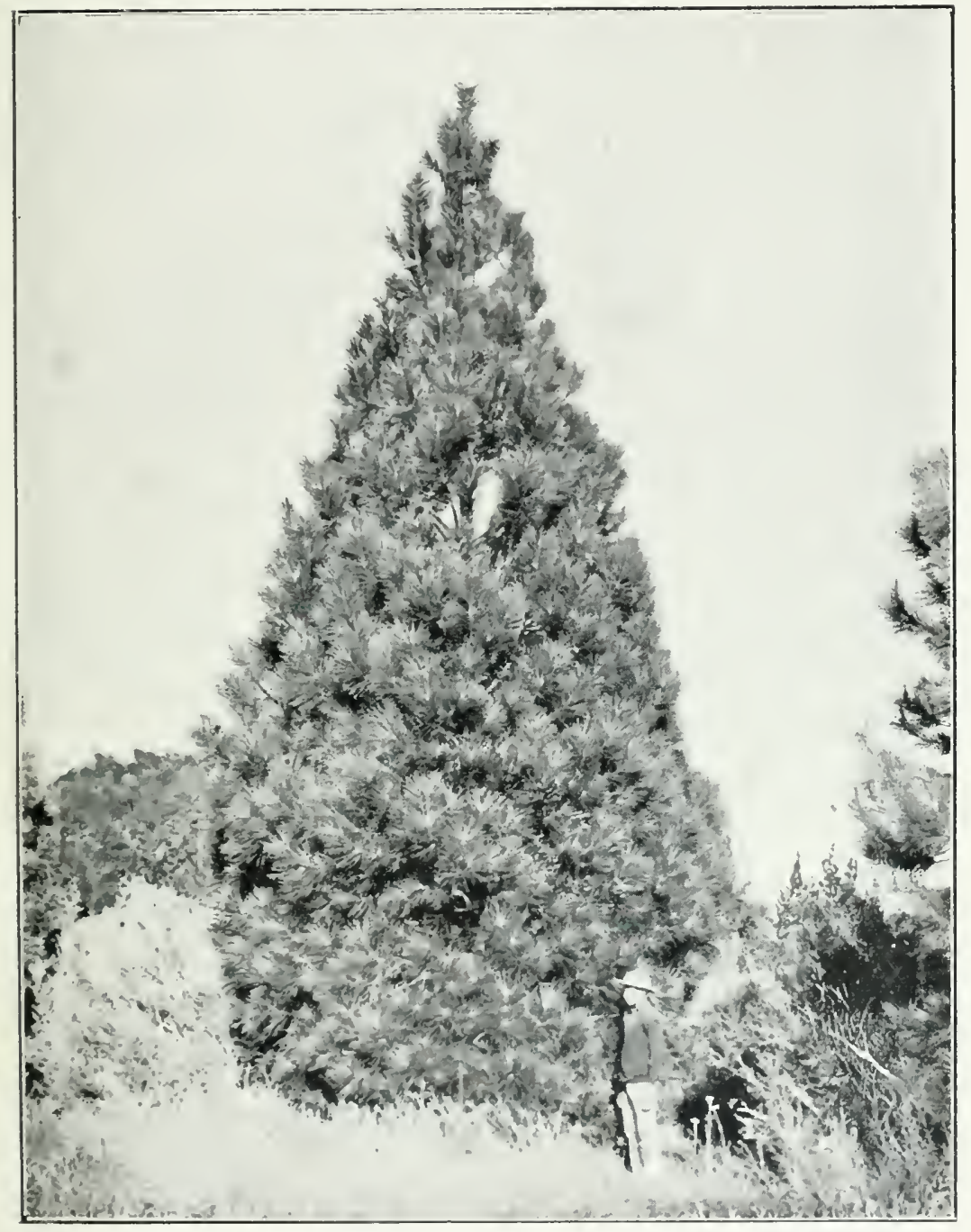

Jlite 29.?

[race 1]. 56. 

Per Mile.

\begin{tabular}{r|r|c||c|c|c}
\hline Distance. & $\begin{array}{c}\text { Number per } \\
\text { Mile. }\end{array}$ & Distance. & $\begin{array}{c}\text { Number per } \\
\text { Mile. }\end{array}$ & Distance. & $\begin{array}{c}\text { Number per } \\
\text { Mile. }\end{array}$ \\
\hline Ft. & & Ft. & & Ft. & \\
100 & 52 & 50 & 105 & 8 & 660 \\
95 & 55 & 45 & 117 & 7 & 754 \\
90 & 58 & 40 & 132 & 6 & 880 \\
85 & 62 & 35 & 151 & 5 & 1,056 \\
80 & 66 & 30 & 176 & 4 & 1,320 \\
75 & 70 & 25 & 211 & 3 & 1,760 \\
70 & 75 & 20 & 264 & 2 & 2,640 \\
65 & 81 & 15 & 352 & 1 & 5,280 \\
60 & 88 & 10 & 528 & $0 \frac{1}{2}$ & 10,560 \\
55 & 96 & 9 & 586 & $0 \frac{1}{4}$ & 21,120 \\
\hline
\end{tabular}

\section{CHAPTER XIV.}

\section{SEA-COAST PLAN'TING.}

$\mathbb{N}^{\mathrm{B}}$ EW ZEALAND, with her 4,330 miles of coast-line, possesses unlimited scope for the energies of the planter in raising shelter-breaks for the protection of his stock, crops, and pastures against the blighting ocean blizzards. None but those who have been engaged in forming plantations on an exposed sea-coast can form any idea of the difficulties to be eucountered in carrying out that kind of work. The principal evil which one has to contend with in sea-side planting is caused by the saline particles, which are carried by the win $\bar{a}$ and deposited with persistent force on the leaves and branches of trees and shrubs. The effects of salt-laden winds are much more injurious to young trees that have been raised in some sheltered nursery than they are to those that have been exposed to the full blast from their initial stages. This is undoubtedly the cause of many failures at the outset. Another evil nearly as great is the fact that the young trees, unless they are well staked, become loosened through wind-waving, leaving a large hole near the neck or collar, in which water rests and causes the bark at that point to decay. (See Plate 16.) In pure sand the failures are also due to wind-waving, and in a great measure to either the accumulation of sand or its renoval from around the trees by wind; therefore before attempting the planting of mobile sands these must be prevented from invading and annililating the young trees, and precautions must be taken to keep the wind from carrying away or otherwise modifying the adjacent surface. 
It is a well-recognised fact that a vast change has taken place during the last decade in the productiveness of our coast-lands, due in many cases to the clearing-away of the natural covering of scrub and trees. So bleak and wind-swept are many positions that the impression prevails that it would be useless to attempt to replant and restore such places to their former state. But the efforts of Nature to cover every naked spot with vegetation are so universal and so persistent that she would herself, if left undisturbed, in process of time restore the natural covering. So long, however, as stock have access to such places the latter must remain comparatively barren. Exclude these and forest-belts may be successfully grown artificially, even on the bleakest shores, in a comparatively short time

Examples of the practicability of reforesting sandy wastes are not wanting in this colony, as elsewhere, where large areas have been so reclaimed or are in process of improvement. Experience has been gained at the cost of many failures and of great patience, but there is still more to be learnt by way of experimenting with many of our sea-coast plants, and especially those endemic to the Chatham and other outlying islands. It should also be noted that whilst certain trees and shrubs flourish with great luxuriance in certain positions the same varieties will be a total failure in other localties, though they may be separated by only a few miles' distance. It is therefore apparent that although certain trees and shrubs are recommended as suitable for sta-side planting all may not be alike successful everywhere, and the planter will require to exercise considerable caution in making his selection. As an example, the common Monterey Pine and Cypress (both natives of storm-swept maritime situations in America) may be seen growing in perfect condition at high-water mark on exposed promontories north of Gisborne, at Shag Point, Otago, and many other localities; whilst the same trees planted on sinilar sites in many places on the east coast of the South Island, or even on the west coast of Taranaki, have proved miserable failures. Again, we have the well-known mutton-bird scrub of Stewart Island (Senecio rotundifolius) and many other sea-side shrubs sometimes growing with their roots practically in salt-water, while their large leaves are neither torn nor disfigured by salt-laden winds. Transfer these shrubs to northern coasts and they turn yellow, drop their leaves, and gradually die off. The explanation of this may probably be due to their dislike of hot, drying winds, and to the want of cool, constantly moist soil, such as they possess when growing under natural conditions. With regard to the Monterey Pine, Cypress, and other hardy trees failing to suceeed in certain positions and yet growing with luxuriance in others, the writer has no explanation to offer.

The preparation of the ground for sea-side planting will necessarily depend on its nature. Where the ground is heavy and sour, stagnant moisture must be got rid of by draining, and the pits 


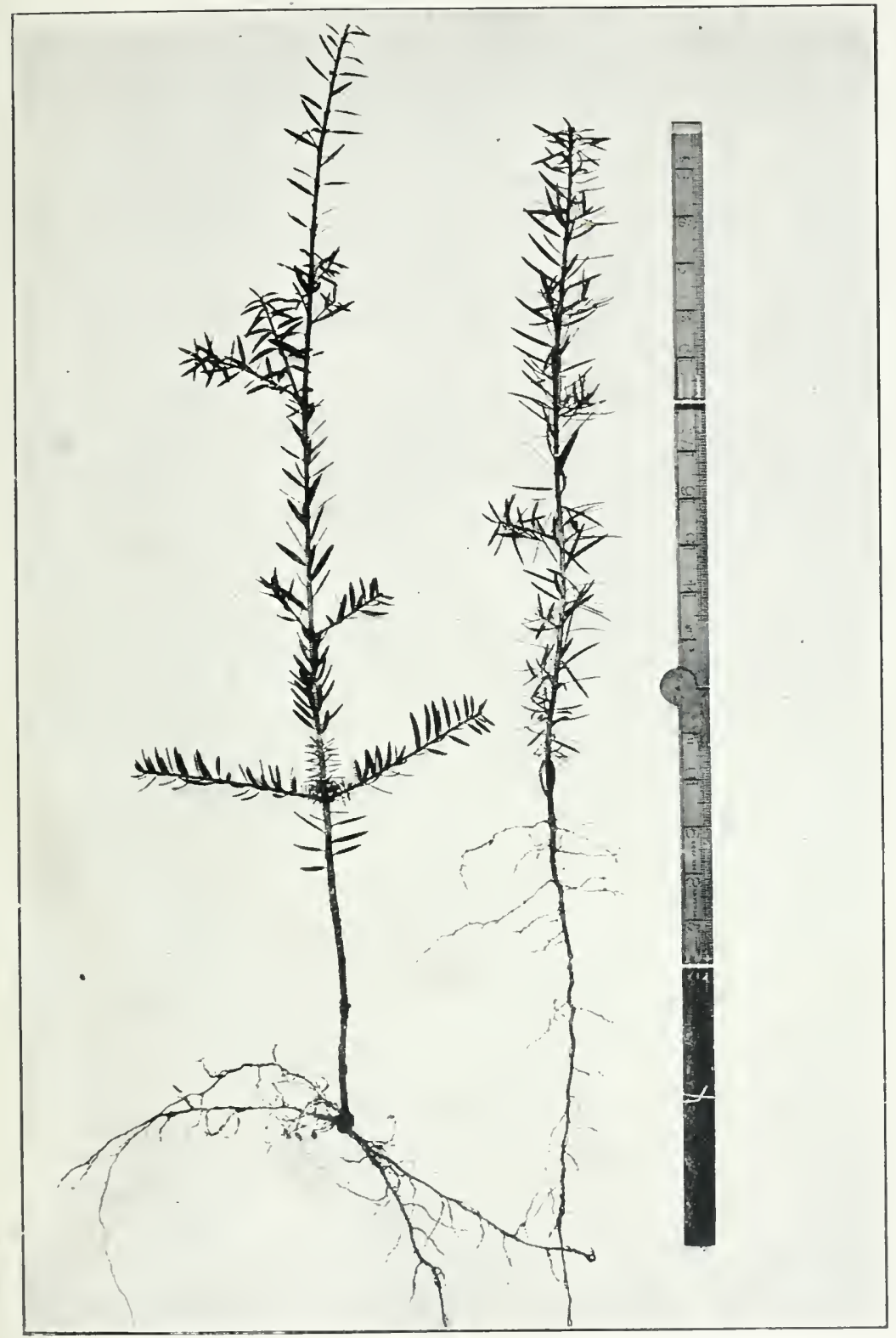

TGT IRA (PODOCARPS TOTARA), ROOTED ClTTING ANI SEEDLING, BOTII SIX Plate 30.] MONTIS OI.D.

[Fuce p. is. 

should be well loosened up some months before planting, in order to sweeten the soil. On pure sand the real difficulties will begin, and, as previously mentioned, the sand must be kept in position, either with fascines or by sorving seeds of some quick-growing plants, such as Gorse, Broom, Lupin, or the common sand-binding Larram-grass. These should be sown broadcast at least two years prior to planting, so as to have the whole well covered, not only to prevent the sand shifting, but to afford protection to the young trees. The trees should be raised in a temporary nursery adjacent to the planting-site if a comparatively sheltered spot containing free sandy soil is available. Most of the varieties recommended for seaside planting will attain sufficient height for permanent planting within two years of seed-sowing, so that both sand-binding operations and seed-sowing in the nursery can be commenced at the same time. It is of the utmost importance that the young plants should be of such a size that they will not be "wind-swayed," and yet sufficiently large to prevent them being covered up with sand. From 8 in. to 12 in. high will be found the most satisiactory size for the purpose. These can be planted with the spade or trowel at any distance apart-say, from $4 \mathrm{ft}$. to $6 \mathrm{ft}$-_amongst the sand-binding herbage. Occasional looking-over will be necessary to prevent the accumulation of sand burying, or the sand-binding herbage choking, the young plants. Dull moist weather should be chosen for planting, and the greatest care taken to prevent drying of the roots.

There is great diversity of opinion as to when sea-side planting should be undertaken. Some affrm that autumn is the best season, others prefer winter, but probably the majority advocate spring as the most successful time. The chief objection to autumn and winter planting is that trees and shrubs planted then are subjected to the storms of winter, which not only loai their branches and foliage with salt spray, but rob them of the greater portion of their leaves. Windswaying also has to be contended with for several months before active growth sets in. Spring planting is therefore recommended, as the trees will start into growth within a few weeks after being put out.

The following trees and shrubs have been found generally adapted for sea-side planting in this colony. Special mention should be made of Pinus muricata, which has so far proved the most successful of all trees in withstanding the blighting effects of salt spray, even when growing in pure sand:-

Trees, Shrubs, and Grasses suitable for Sea-side Planting. Trees.

Acer pseudo-platanus (Sycamore). Acacia pyracantha (Golden-wattle). Alnus giutinosa (Common Alder). Araucaria, all species.

Corynocarpus lavigata (Karaka). Cordyline australis (Cabbage-tree). Chrmacyparis Lazosoniana (Lawson's Cypress).
Cumvessus macrocarpa (Honterey Cypress).

Casuarina quadrivalvis (She or Swamp Oak).

Griselinia littoralis (Broadleaf).

Lnburnum vulgare (Laburnum).

Myoporam lalum (Ngaio).

Pinus Austriaca (Austrian Pine). 


\section{Trees, Shrubs, and Grasses, wtc.-continued.}

\section{Trees-continued.}

P. Canaricusis (Canary Island Pine).

P. Virginiana (Scrub Pine).

P. radiatix (Monterey Pine).

P. muricata (Prickly-coned Pine).

$P$. rigida (Pitch Pine).

$P$. halepensis (Aleppo Pine).

$P$. Laricio (Corsican Pine).

P. pinaster (or maritima) (Cluster Pine). Ulmus montana (Scots Flm).

$P$. cembra (Stone Pine).

Populus, most species (Poplar).

Pyrus aucuparia (Rowan Tree).

Quercus ilex (Ewergreen Oak).

Q. stellata (Post Oak).

Salix, many varieties (Willows).

Thuja occidentalis (Arborvitæ).

Shrubs.

Coprosma Baneri (Naupata, or Tau- Pittosporum, most species. pata).

Cytisus scoparines (Common Broom).

Euonymus Japonicus.

Escallonia macrantha.

Plagianthus divaricatus.

Rhammes frangula (Berry-bearing Alder).

Senecio Huntii (Rautene).

S. rotuniifolius (Leather-leaf).

Hippopha rhamnoides (Sea Buckthorn). S. Muellerii.

Lavatera arborea (Tree-Mallow).

Lycium Afrum (African Box-thorn).

Olearia avicennifolia (Akeake).

O. Colensoi (Tupari).

O. Traversii (A keake).

Olearia Forsterii (Golden Akeake).

Tamarix Gallica (Tamarisk).

Olex europaus (Gorse).

Veronica, most species (Koromiko). $V$. elliptica, V. arborea, V. Benthamii, V. ligustrifolia, V. macroura, and V. salicifolia are the best.

Grasses, ic.

Arundo conspicua (Toetoe).

Elymus arenarius (Lyme-grass).

Phormiun tenax (Flax) (Harekeke).

Psamma arcnaria (Marram-grass).

Mesembryanthemum, numerous varieties (Pig-face).

One of the most practical papers ever published in reference to coastal planting was read by Mr. James Burgess, President of the Cape Egmont Horticultural Society, at the New Zealand Horticulturists and Fruit-growers' Conference held in Dunedin during June, 1901. The information contained therein is of such a valuable nature to settlers in that district that it has been deemed desirable to reproduce it here.

\section{SHELTER-TREES IN CAPE EGMONT DISTRICT.}

The district known as the Cape Egmont district, on the west ccast of Taranaki, extending from Stony River on the north to Opunake on the south, until about twenty-two or twenty-three years ago was occupied solely by Maoris, and, except by a very few adventurous men, was quite unexplored beyond a few hundred yards from the beach, along which ran the only track connecting the country settled to the north with that settled to the south. A strip of country from four to six miles in width along the beach (except in numerous patches, which were cultivated by the Maoris) was covered with a tangled and dense growth of fern, flax, cabbage-palm, \&c., varied by frequent patches of scrub, where flourished luxuriantly the numerous and beautiful species of smail trees and shrubs indigenous to the North Island of New Zealand, and occissionally a small remnant of heavy bush, which, judging from the remains found in swamps, must once have corered the district. Under the shade of the scrub the ground was covered with a profusion of lovely palms and ferns, whilst in the spring large patches of it were lit up by masses of the beautiful white clematis. 


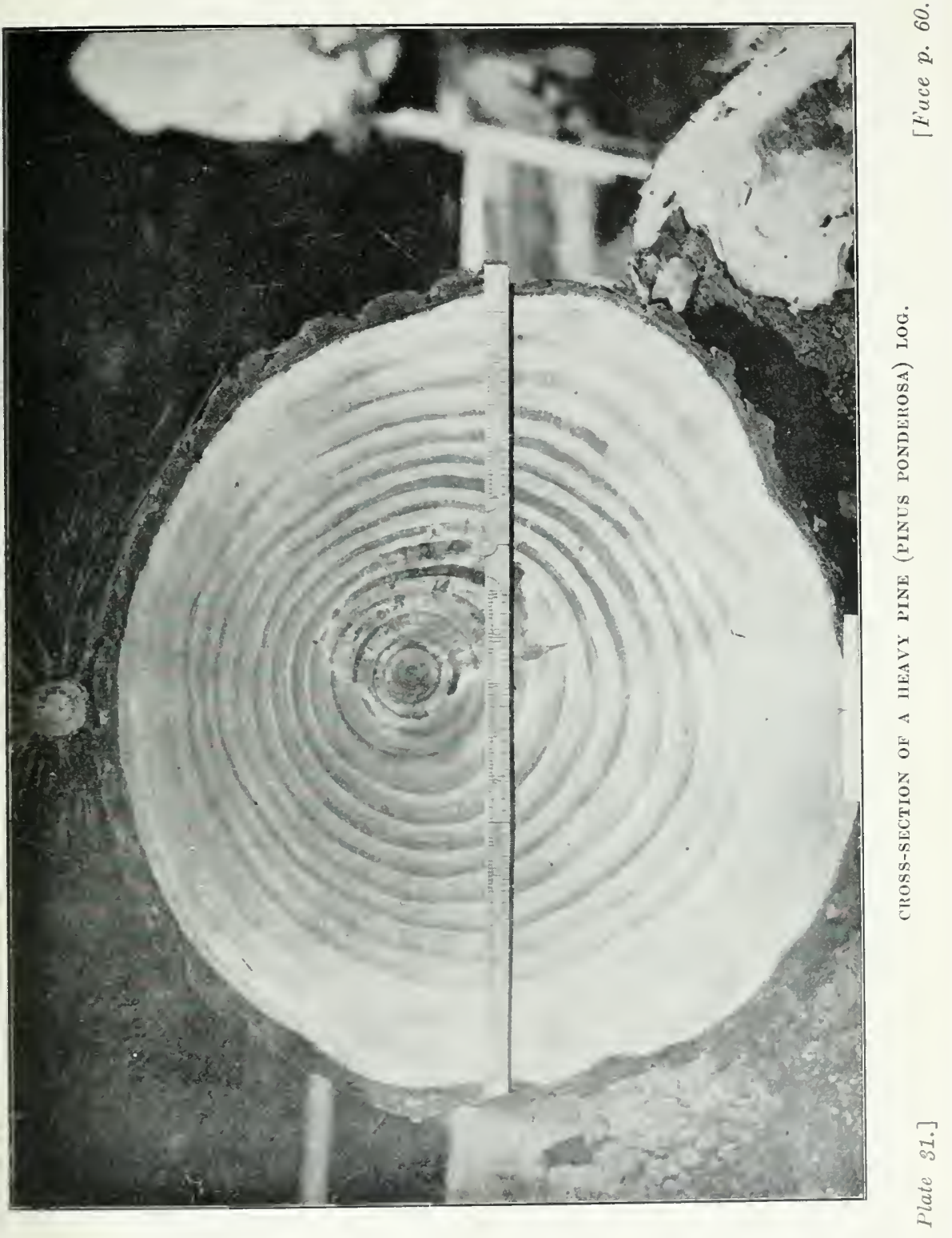



From this strip of comparatively open land to the base of Mount Egmont the country was covered with an almost unknown forest, where towered the Rata, Rimu, Kahikatea, and other giants of the forcst. The open land was overrun with innumerable wild pigs of the Captain Cook species, whilst forest and open land were tenanted by droves of cattle as wild and wary as deer, in addition to large numbers of pigeons, tuis, bell-birds, and numerous other species.

Rather more than twenty years ago camps of Armed Constabulary were formed in the district, and road-making and surveying went on. Shortly after. wards a few European settlers arrived and commenced to make homes for themselves. Seeing the success with which the Maoris cultivated maize, tobacco, melons, kumaras, and other tender plants, and the heavy crops of peaches borne by large and healthy trees in the old neglected clearings, the settlers jumped to the conclusion that anything they chose to plant would flourish, and began planting without taking into ccnsideration the effect that would be produced upon the climate by clearing off the native growth by which the country was covered. But, alas! this delusion was soon dispelled. In two years peaches became almost extinct, deciduous trees would only grow where sheltered from the southerly gales by some eminence, the patches of native scrub left standing began to look unhealthy, whilst melons and other tender plants became very uncertain and difficult to grow. The climate appeared to get worse every year, until about five years ago it culminated in two severe gales from the south (which came in February), killing Gum-trees which bad attained a height of fully $30 \mathrm{ft}$.; badly damaging, and even killing, many of the Macrocarpa, Laurel, and Akeake; even the Insignis did not escape severe injury; and only the Maritima, Cabbage-palm, and flax were uninjured. Thousands of fruit-trees were utterly destroyed, and thousands more have since dragged out a miserable existenceunlovely and useless. Yet wherever shelter from the south wind exists plants and trees from widely separated countries, equally with those native to the soil, flourish luxuriantly and amply repay the cultivator for his labour.

On account of projecting so far out into the Pacific, the Cape Egmont district is subject to but few and very light frosts, snow never falls near the coast, and there is practically no winter, but unfortunately of late years very little spring, and at any time in the year tender plants are liable to be destroyed by salt blizzards where not well sheltered. Wherever good shelter exists such fruits as the orange, lemon, and guava flourish equally well as the apple, quince, or gooseberry. Azaleas, hydrangea, and cannas luxuriate by the side of the modest primrose, violet, and pansy, all alike independent of the least artificial heat or protection. In consequence of growing all the year, geraniums, pelargoniums, and other half hardy plants attain the dimensions of large shrub;, and a bunch of beautiful blossom to decorate the home can be cut in the open garden during every month of the year. Among vegetables an equal variety flourish; the capsicum and tomato ripen side by side with the pea and the bean-all sown alike in the open garden.

From the above facts it may be judged how essential it is to have plenty of good shelter, and to know what kinds of trees and shrubs will best suit the conditions prevailing in the district. As settlement by Europeans only commenced at so recent a date, very little experience in this direction is available to the planter, and, unfortunately, making experiments in tree-planting requires much time and the exercise of great patience before any reliable knowledge can be obtained on the subject. Trees advertised as perfectly hardy in surrounding districts are procured, and perhaps for four or five years flourish so well that the settler begins to 
congratulate himself upon having made a good choice; the next year comes a blizzard, and bis trees are killed outright or badly damaged. The process is repeated, perhaps, again and again until, disgusted with repeated failures, the attempt is abandoned in disgust. Yet if gardening is to succeed in the locality shelter adapted to its conditions must be planted; and the Government of New Zealand would be doing the greatest service to horticulturists and farmers if, through its experts, it could find out what trees and shrubs would best withstand the deadly effects of the salt blizzards and form a thick and lasting shelter in the shortest tims. What adds very much to the damage done is that the gales freque'stly occur immediately after warm and forcing weather has stiarted vegetation into luxurious growth; consequently the foliage is tender and in no condition to withstand them. So far the Pinus maritima, Olearia, Taupata, Eleagnus, Euonymus, Cabbage-palm, and flax appear to be perfectly hardy in any situation. The box-thorn (although stripped of its leaves during a gale) soon recovers. The Pinns insignis is fairly hardy in most situations, although not in all, and is rather liable to be blown out by the roots at times.

A shelter-belt capable of weathering the fiercest gales might be formed by planting-first (on the south) a good row of flax, next two or three rows of Cabbage-palms (which might be cut back to various heights), then a row of Olearia, and finally one of Macrocarpa, Pinus maritima, or Pinus insignis. Cattle being particularly destructive to flax and young Cabbage-palms, the plantation would need to be well fenced with barbed wire, and a bedge of box-thorn might be planted at the same time, which, if properly cultivated, would in a very few years form such an efficient cattle-proof, and even boyproof fence that the wire could be safely removed. One of the most im. portant points to be aimed at in planting is to keep the cold gales from getting under the trees near the ground. More particularly is this the case with many of the native species, whose roots grow very near the surface; consequently, for the outside row some plant, such as the flax, which keeps dense close to the ground and is perfectly hardy, should be selected. If the orchard or garden to be planted be small, it may be objected that the amount of ground taken up by the shelter is out of all proportion to that sheltered. But in the more exposed positions this seems unavoidable until bardier trees and shrubs of more dense growth are introduced.

Unfortunately, the first idea of settlers when first taking up land appears to be that a clean sweep should be mule of everything growing upon it. Fire and steel in a few years leave the country practically without shelter to break the force of the gales. Soon the discovery is made that the clim ite is not what it once was, an $\mathrm{i}$ has changed very much for the worse. Not only do horticulturists suffer from the ch inge, but the cattle, having nothing better than wire ence to shelter under, require far more feeding, and even then do not thrive as Defore; firewood and timber become scarcer and dearer every year, and the necessity for replanting is admitted by all, but, unfortunately, practised by few. In this case, as in most others, destruction is far easier than construction, and shelter that might have been preserved by a few weeks' labour and a small outlay for fencing has to be replaced at a far greater outlyy of capital and labour. Long years have to be waited whilst the plantations are growing, and even when grown formal rows of pines are a poor substitute for the beautiful native bush that has been destroyed.

Ta ranaki, far and wide, has laid claim to the title and been known as "The 


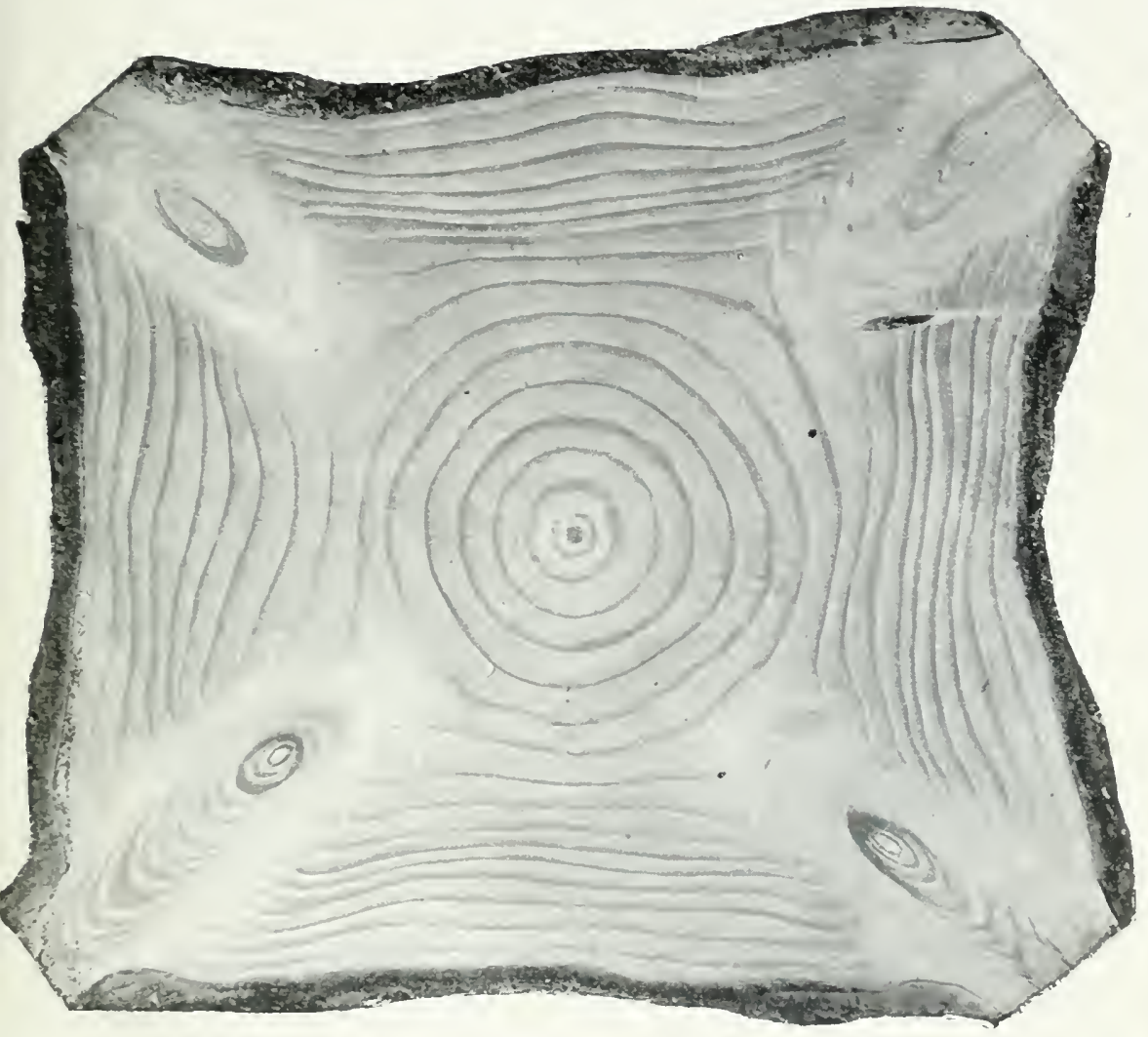

Plate 32.]

CliOSA-SFCTION OF A SILTER-FIR LOG.

[Eace p. 6.]. 

Garden of New Zealand." If the Cape district is to retain its claim to share in the proud title it must plant shelter on a large scale, and that without delay. At present the trouble is that so few plant. When every farmer finds that it pays him to do so, as it undoubtedly will, the difficulty experienced now will rapidly decrease, for each fresh breakwind planted will help to protect the next and give it a better cbance of establishing itself. According to statistical returns, the whole of Taranaki has planted only the paltry area of about 900 acres, while Auckland and Canterbury have each plauted about sixteen times that amount.

Under the Atkinson Government landowners who planted forest and shelter trees and attended to them until properly established were given land scrip in proportion to the amount planted. Could not something on the same lines be done now? The need for planting becomes not less but greater every year. Thousands of acres in the colony, and patches on most farms, are of little use for any other purpose than growing trees, or in any case would be better used in this way than auy other; but on account of the long time that has to be waited before any return is obtained for outlay few are disposed to plant. The benefits derived from extensive planting would be universal, as it would greatly improve the climate, the scenery, and the products of the whole colony. The Government of the colony has offered bonuses for the production of many things of infinitely less value than trees. Night it not, then, do something to encourage their planting? Whenever land having bush or scrub growing upon it is sold or leased it might be made a condition that a certain percentage of it should be properly fenced and protected, and, if the bush should be accidentally or wilfully destroyed, that it should be immediately replanted by the occupier. an open land to be disposed of it would be no hardship to require that a moderate proportion of planting should be done by the occupier; whilst in the case of lands already disposed of by sale or lease some such inducement as an advance of money for a short term, without interest, to pay cost of foncing and planting might be made.

The subject is one of the greatest importance, for, in addition to the fastapproaching scarcity of timber, which is essential for so many purposes, there can be no reasonable doubt that the destruction of all trees over a large area renders the climate less equable, and the country denuded of forests is liable to greater and more sudden extremes of heat and cold, drought and flood, than one that is fairly well wooded. Although the only question asked be, Will it pay to plant? the answer must be emphatically, Yes ; it will pay in the extra comfort afforded to cattle, the earlier start made by vegetation in spring, the greatly reduced risks of having crops destroyed, in the beautiful and useful products of the garden and orchard, in the production of firewood and posts, that are always wanted, and, in addition, it will add beauty to the landscape, whose value cannot be stated in cash. Most of the countries of Europe which have allowed the reckless destruction of forests to take place have bitterly regretted their mistake, and are now, at great cost, endeavouring to rectify their mistaken course. Let us, then, before our climate and scenery are ruined by the reckless destruction that is going on, put a stop to the process and begin planting on an extensive scale. The sooner this is done the better will it be for our beautiful colony and its inbabitants. Our extensive and luxuriant pasture-lands render this an ideal spot for dairying and many other eccupations. Clear off all your shelter and the small streams will become dried up in summer, whilst becoming țurbid torrents carrying of your soil to the ocean after heavy rain in winter. The equable climate will change to one where drought alternates with flood, whilst your beautiful and attractive scenery will be but a sad memory of the past.

I can lay no claim to having written a scientific or exbaustive paper on my subject, but if the few facts and theories advanced induce oibers better qualified tban I to take up the matter the time spent in preparing it will not bave been wasted, and the trouble taken will be amply repaid if it belps in any degree to accelerate attaining the desired object. 


\section{DR. TRUBY KING'S PAPER ON SEASIDE PLANTING.}

Sir,-

Karitane, Otago, 1st December, 1903.

In response to your request for an account of experiments in seaside planting carried out at Karitane during the last four years, I will give the gist of an address on the subject read before the Otago Institute last year, with amplifications based on later experience.

I assume that what you want is a statement of practical experience and of such conclusions as we have been led to form in regard to seaside planting in this particular district.

The area to be dealt with consisted of two entirely distinct parts-namely, (1) a sand istbmus about 4 chains wide and 8 chains long, connecting the Karitane Peninsula with the mainland; $(2)$ the peninsula itself.

In the early days of the colony some balf-dozen whalers had their huts erected on the isthmus, and the sand was securely held against wind and sea by a natural growth of flax and native grasses. Later the huts were abandoned, and cattle soon destroyed the vegetation both of the isthmus and the neighbouring sandhills along the coast of the mainland. Up to this time the peninsula, which rises steeply to a terrace about $30 \mathrm{ft}$. or $40 \mathrm{ft}$. above sea-level, had been quite free from drifting sand, and was closely covered with a luxuriant growth of grass and clover. Now the sand commenced to be drifted along the beach and across the isthmus, some finding its way into the estuary and contributing to the shoaling and ruining of the port, and another portion travelling up the slopes of the peninsula, killing all vegetation in its path except a gorse-bush here and there. Sometimes the ground was so deeply covered with sand that a dray could be driven over the remains of the fences, and at others the bare earth, devoid of any sign of plant-life, was left exposed. The isthmus became so much lowered that from time to time it was submerged during high tides, and the river threatened to resume its ancient course straight through the neck, which would have completed the ruin of the port.

At this stage, four years ago, the matter was taken in hand by the Karitane District Improvement Society. The isthmus was fenced, and manuka scrub was lashed to the bases of the posts which skirted high-water mark in order to accumulate a sand-barrier. The scrub was maintained at about a foot or more above sand-level, and as the sand rose other layers were added from time to time. A second similar line of scrub defence, parallel to and a quarter of a chain back from the first line, was erected later. In the meantime marramgrass had been planted; and a clay embankment and roadway, protected by the scrub and fringe of marram, was carried across the isthmus from the mainland to the peninsula. At the present time, at the end of four years, an uniriterrupted sand-dune stands as an effective barrier to all further sea-encroachments. This dune, 8 chains long by over a quarter of a chain wide, and averaging from $6 \mathrm{ft}$. to $7 \mathrm{ft}$. high at the crest, is densely covered with marram-grass, the leaves of which carry the wind-shelter $2 \mathrm{ft}$. higher. This sand-ridge is increasing in height fully $2 \mathrm{ft}$. a year, and it has raised the level of the beach in an inclined plane stretchiug several chains down to low-water mark. Three things have thus been accomplished-(1) Some thousands of tons of drift sand, in transit to shoal the estuary and prevent plant-growth on the land, have been arrested, bound together, and laid down in the desired position as a sea-wall sheltering a permanent roadway. (2.) A wind-barrier has been formed $8 \mathrm{ft}$. high. This now shelters plantations of Olearias, Box-thorns, Pines, Cypress, Willows, and Cabbage-trees, which are making good growth to the north of the roadway. Clover has sprung up wherever the sand is not occupied by marram-grass or shrubsall this taking place where only a few years ago sea-wreckage was strewn at every specially high tide. (3.) The portion of the peninsula which has been rendered for the time being valueless by drifting sand bas clothed itself with the most luxuriant covering of grass and clover wherever the ground is not occupied by our plantations of shrubs and trees.

When the arrival of fresh sand at the peninsula was stopped, the winds soon dispersed and cleared off most of what had accumulated; and if the object had been merely to secure open pasture-land, there was nothing to prevent 


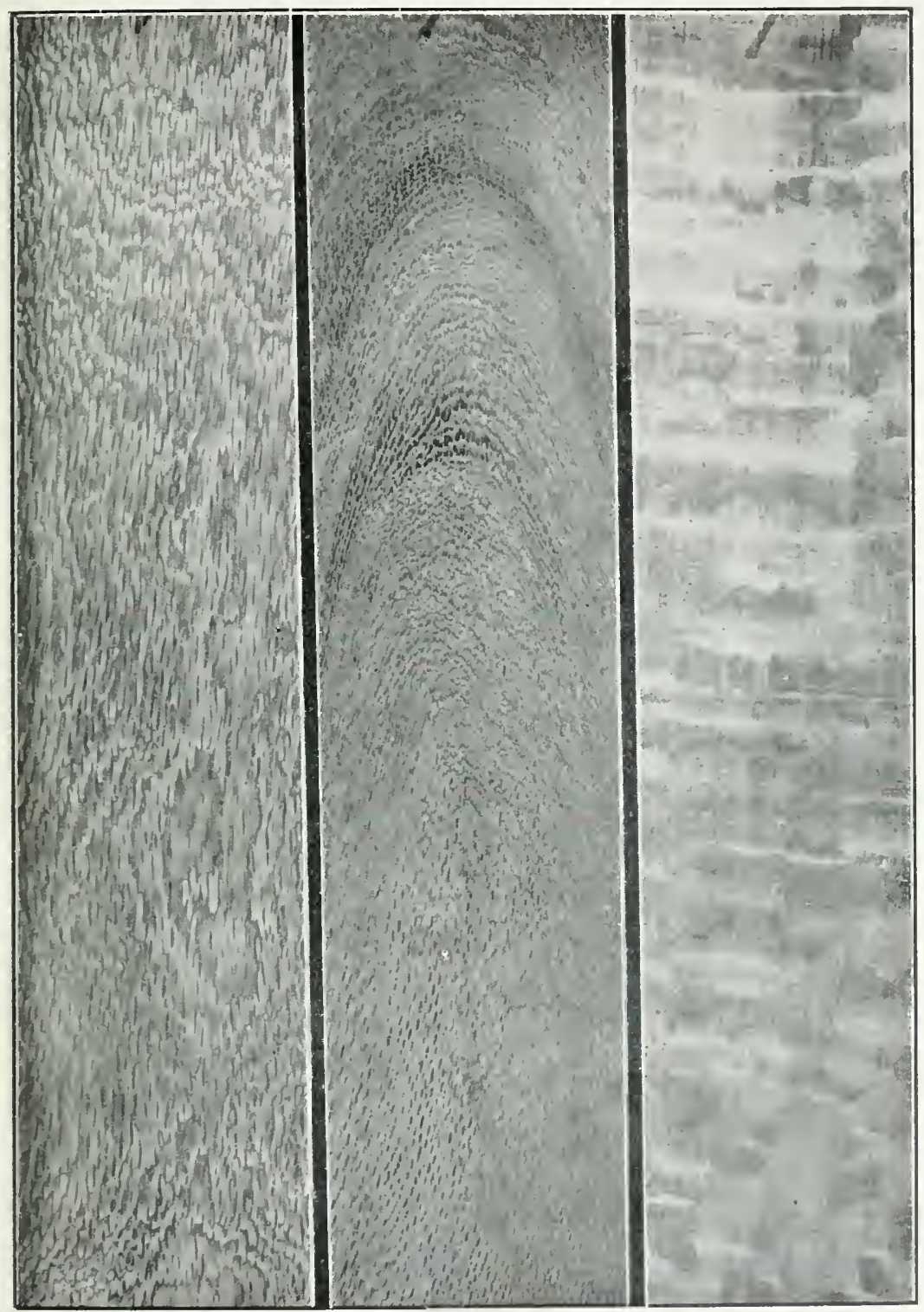

LONGLTUDINAL SECTIONS OF REWAREWA (KNIGHTIA EXCETSA).

Plale 33.]

[Face p. o. . 

the immediate sowing of clovers, which would have covered all the denuded ground in a season. It was desired, however, to commence planting the publio domain of some 33 acres for shelter and ormamental purposes, and several private properties needed similar protection. Here was virtually an island, some 43 acres in extent, rising abruptly from the sea to a height of from $30 \mathrm{ft}$. to $130 \mathrm{ft}$., and the problem before us was how to clothe it with shelter most expeditiously and economically. The Domain Board had practically no funds, and certainly nothing to expend in mere experimenting. The property immediately adjoining the isthmus belonged to myself, and I decided to give a fair trial to the methods of planting which had been found effective on the islands and seacoast of Scotland. Fortunately, ample data were available in a series of essays on the subject published in the Transactions of the Highland and Agricultural Society. With these before us, screens of palings, manuka scrub, \&c., were erected round the margin of the terrace, and, under cover of these shelters, belts of Conifers, Gums, and the hardier deciduous trees. and some native evergreens, such as Ngaio and Cabbage-tree, were planted. These now form dense established thickets, in which the Blue-gums reach $20 \mathrm{ft}$. in height, pinis insignis $16 \mathrm{ft}$., Sycamore $9 \mathrm{ft}$., Silver-birch and Rowan $8 \mathrm{ft}$., \&c.

The success of these plantations could not have been greater, but the initial cost of providing a shelter rendered them unnecessarily expensive. There can be no doubt that shelter is the first consideration for seaside planting, and that no form of shelter quite equals a "dead fence" of palings or scrub if it be desired to raise a belt of trees to a given height in a minimum of time. Nevertheless, experience has convinced us that, given a reasonably good soil and proper preparation, a screen of living plants is equaliy effective, and entails in practice no great loss of time if the work be carried out systematically and with proper judgment and foresight. We find it an inestimable advantage to thoroughly work the whole of the soil beforehand, and where this is feasible we never resort to pit-planting. Trenching by hand is, of course, out of the question on the score of expense, and is unnecessary, in this district at least, because special ploughing and cultivating prove equally effective. We plough shallow in the summer, clean well with cultivator and harrows, plough deeply with a digger-plough in the autumn, crop with potatoes the following spring where suitable, and realise a profit. Where too exposed for potatoes we sow down in crimson clover or annual red clover. In either case the ground can next be easily cross-ploughed to the depth of $15 \mathrm{in}$. or $16 \mathrm{in}$. by using two teams, the digger-plough being preceded by a swing-plough, which lets the former down the desired depth. By this means a most perfect mixture of soil and subsoil is obtained with a preponderance of subsoil in the top $3 \mathrm{in}$. or $4 \mathrm{in}$., which thoroughly breaks down during the winter. Thus, availing ourselves of ordinary farm implements and teams, at the end of a year we have got our ground into the best possible condition without appreciable expenditure. Meantime, a few yards of the windward side of the belt-area should have been sown or planted with shrubs in order to provide a narrow pioneer screen instead of its being cropped with potatoes or clover in the early spring; and if quick-growing plants, such as IIaritime Pine, Lupin, Tree-mallow, and Akeake, have been used there should be an effective bedge $3 \mathrm{ft}$. or $4 \mathrm{ft}$. high to shelter the more permanent shrubs and trees, which we prefer planting early in autumn (at the end of April or in the beginning of May). With well-worked ground and some shelter we find that on the whole the autumn planting gives better results here than spring planting, and the selection of this time falls in best with our general scheme. The width of the whole belt and of the portion devoted to a pioneer screen are essential considerations which must be determined by the object in view and the character of the locality as regards exposure to cutting winds, slope, soil, \&c. In general, I should say that in this district irom half a chain to a chain is usually enough, and the outer third of tbis may be a pioneer scrcen. The formation of this screen is really the essential matter, because once shelter has been established a wide range of trees and shrubs will flourish at the seaside as well as, or even better than, inland. The bancful influence of the seabreezes laden with salt ceases when we moderate the rate of the air-currents to a

Forestry-3. 
certain degree, and diminishes as the trees grow taller on account of acclimatisition and the increased tonghness and strength of the leaves and twigs of mature plants. The more gentle the rise of the inclined plane of the foliage of the shelter belt from windward to crest the less seriously will it be affected by wind, and hence it comes about that if our plantation be on quickly rising ground we must increase the width of the belt; and the same applies wherever the winds are excessively severe and cutting. If ground-space, time, and expense were of no importance, the ideal seaside shelter would commence with marram or lyme grass on the low-lying sands and rise gently up the slopes through graded Veronicas, Flax, Senecios, Olearias, Pittosporums, \&c., to plantations of the loftier Conifers, Gums, deciduous trees, \&c.

In experimenting with screen-formation at Karitane we lost much time in places, and were put to considerable expense, by the more or less complete failure of the majority of the plants relied on at Home. Sea-buckthorn, Tamarisk, Snowberry, and Dogwood are universally recommended as pioneers by all Home authorities; yet, with the exception of Tamarisk, none of these plants have made as much headway in fully exposed situations here in three years as some other shrubs have done in a single season. Even the Tamarisk has proved capricious, and has done well only under comparatively favourable conditions. None of our evergreen Oaks have made and sustained more than a few inches of growth per year, and the same applies to the English Maple. In this district, whatever value such trees may ultimately have, they are useless as pioneers. Gorse, Broom, and Briar, in spite of their thriving, cannot be recommended, on account of their coming under the Noxious Weeds Act.

The following list embraces the representative screen-plants of each species which have grown best with us, arranged roughly in order of estimated average height at the end of, say, one, two, and three years when planted in well-worked ground with open exposure to prevailing winds. The height when planted is assumed to be about $6 \mathrm{in.}$. In some instances our specimens at Karitane have not been planted the ful! time, and I have then filled in data derived from plants growing elsewhere under similar conditions. In the fourth column are given the heights to which the various species might possibly attain under favourable conditions as to shelter, \&c., these figures being for the most part taken from Floras and works on gardening and forestry. By making comparisons of the various plants one with another in the several columns, it will be realised that in the formation of a shelter-screen the data as to growth in full txposure during the first three years is more immediately important tian the information asually supplied as to possible ultimate growth. It would be obviously an advantage if one could also give data as to probable ultimate height when fully exposed, so that the figures in the fourth column might be directly comparable with those given in the first three columns, but unfoltunately such information is not available.

It must be understood that the figures I give are only a rough approximate average even for the narrow range of conditions within which our plantations have been made. Thus, in regard to the Veronicas, it will be found that the growth of the last three in the list is set down as identical for the first three years, though in practice this would never be the case. Under open exposure to severe salt laden gales Veronica salicifolia will make little progress, and may be killed, though $V$. elliptica will flourish; while under relatively favourable conditions $V$. salicifolia will outstrip $V$. clliptica, and is rightly described as the quicker grower under ordinary circumstances. It will be seen that Baccharis halimifolia is assigned a height of $4 \mathrm{ft}$. $6 \mathrm{in}$. at the end of three years, and Senccio rotundifolius only $4 \mathrm{ft} .3 \mathrm{in}$., and this is probably a fair average for the district; but the Senecio is much the hardier under severe stress of weather, and would make vigorous growth where the Baccharis would fail. Given a little shelter, Goat-willow or the native H'uchsia may grow twice as quickly as Senecio rotundrfolius, but the latter is incomparably hardier, and under severe stress will grow much quicker than either. We have plantations of African Boxthorn which are growing twice as quickly as plants of Senecio rotundifolius immediately alongside, but in free open exposure the Senecio makes much the quicker progress. 


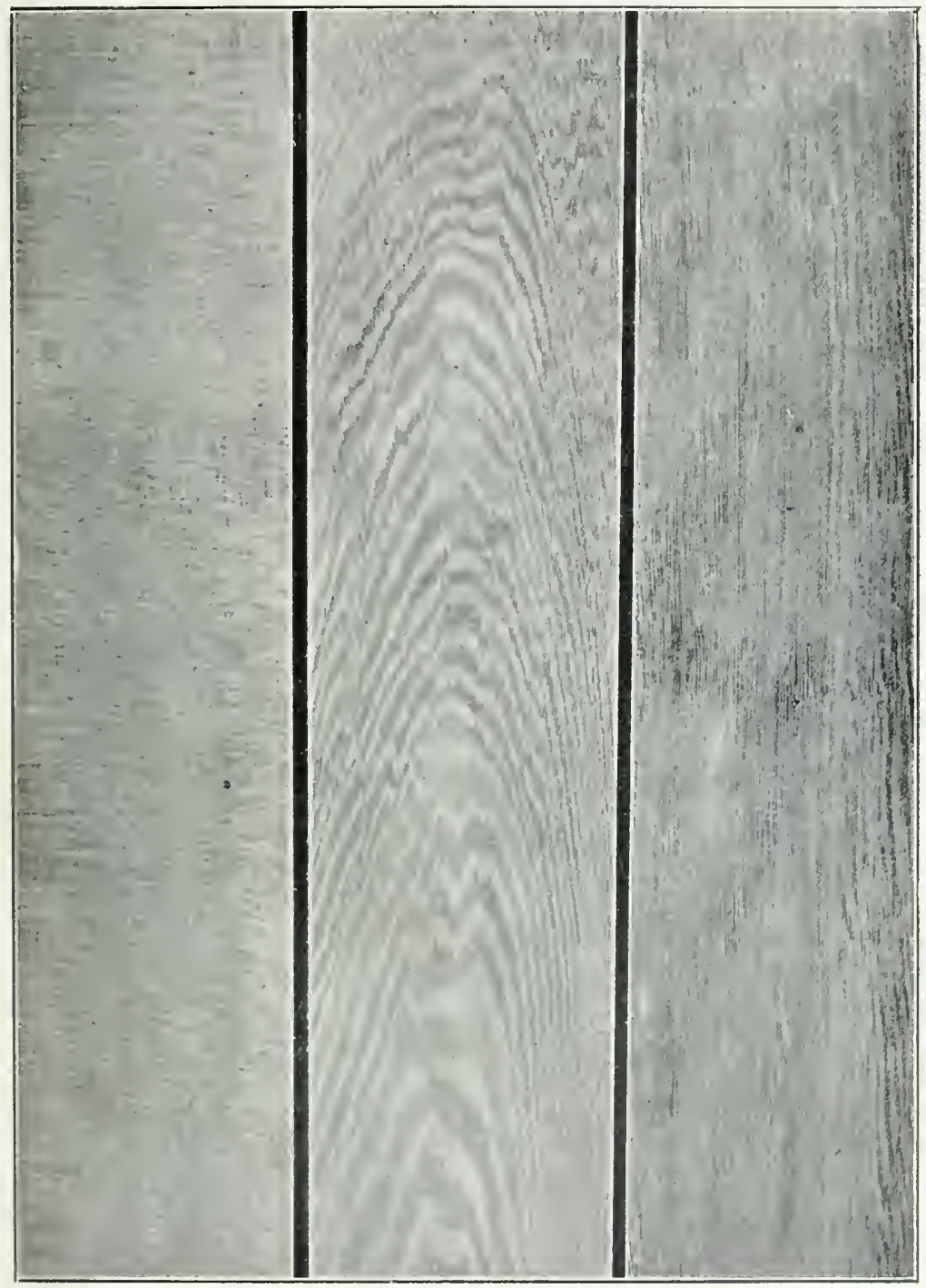

LONGITEDINA SECTIONS OF KOWHAI (SOPHORA TETRAPTERA). I'lute 34.] [Face p. E6. 

Table of Shrobs and Trees for Seaside Shelter.

\begin{tabular}{|c|c|c|c|c|c|c|c|}
\hline \multirow{2}{*}{\multicolumn{2}{|c|}{$\begin{array}{c}\text { Common or Native } \\
\text { Iame. }\end{array}$}} & \multirow{2}{*}{\multicolumn{2}{|c|}{ Botanical Name. }} & \multicolumn{3}{|c|}{$\begin{array}{l}\text { Approximate Height } \\
\text { in Open Exposure } \\
\text { at the- }\end{array}$} & \multirow{2}{*}{ 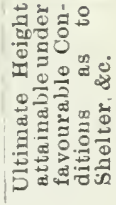 } \\
\hline & & & & $\begin{array}{l}\text { End of } \\
\text { One } \\
\text { Year. }\end{array}$ & $\begin{array}{l}\text { End of } \\
\text { Two } \\
\text { Years. }\end{array}$ & $\begin{array}{l}\text { End of } \\
\text { Three } \\
\text { Years. }\end{array}$ & \\
\hline Marram-grass & . & Psamma arenaria & & $\begin{array}{cc}\text { Ft. in. } \\
1 & 0\end{array}$ & $\begin{array}{l}\text { Ft. in. } \\
20\end{array}$ & $\begin{array}{l}\text { Ft. in. } \\
26\end{array}$ & $\begin{array}{l}\mathrm{Ft} . \\
3\end{array}$ \\
\hline New Zealand Flax & $\begin{array}{l}\cdots \\
\cdots\end{array}$ & Phormium tenax & $\cdots$ & 10 & 20 & 30 & \\
\hline Lupin & .. & Lupinus arboreus & .. & & 60 & 70 & 8 \\
\hline Tree-mallow. . & .. & Lavatera arborea & $\cdots$ & 50 & 70 & 80 & 9 \\
\hline & & Veronica Diffenbachii . & . & & & 20 & 4 \\
\hline Koromiko & & $\begin{array}{l}\text { " macroura } \\
\text { " elliptica }\end{array}$ & $\because$ & $\begin{array}{rr}0 & 10 \\
1 & 0\end{array}$ & $\begin{array}{ll}1 & 6 \\
2 & 0\end{array}$ & $\begin{array}{ll}2 & 6 \\
3 & 3\end{array}$ & 6 \\
\hline & & arborea & . & 10 & $\begin{array}{ll}2 & 0 \\
2 & 0\end{array}$ & $\begin{array}{ll}3 & 3 \\
3 & 3\end{array}$ & $\begin{array}{l}20 \\
20\end{array}$ \\
\hline & & salicifolia & .. & & 20 & $\begin{array}{ll}3 & 3\end{array}$ & 25 \\
\hline . & & Senecio compactus & .. & & 12 & 19 & 3 \\
\hline Puharataiko.. & & " laxifolius . & .. & $\begin{array}{ll}0 & 9\end{array}$ & 16 & 23 & 4 \\
\hline $\begin{array}{r}\text { Pubarataiko.. } \\
. .\end{array}$ & - & rotundifolius . & -. & 13 & 26 & 43 & 30 \\
\hline Tete-a-weka... & & $\begin{array}{l}\text { Olearia nitida } \\
\text { angustifolia }\end{array}$ & $\cdots$ & & 20 & 30 & 8 \\
\hline Tupari $\quad$ T. & $\because$ & $\begin{array}{ll}\text { " } & \text { angustifolia } \\
& \text { Colensoi }\end{array}$ & . & & $\begin{array}{ll}1 & 9 \\
1 & 9\end{array}$ & $\begin{array}{ll}2 & 6 \\
2 & 9\end{array}$ & 25 \\
\hline Akepiro & & macrodonta & $\because$ & 10 & 20 & $\begin{array}{ll}2 & 0 \\
3 & 0\end{array}$ & $\begin{array}{l}35 \\
20\end{array}$ \\
\hline $\begin{array}{l}\text { Akepiro } \\
\text { Akeake }\end{array}$ & - & Forsterii & . & 13 & 26 & 39 & 20 \\
\hline $\begin{array}{l}\text { Ikeake } \\
\text { keake }\end{array}$ & $\cdots$ & avicennirfolia. & .. & 16 & 30 & $4 \quad 3$ & 25 \\
\hline 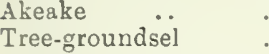 & .. & "Traversii & .. & 26 & 53 & 80 & 30 \\
\hline $\begin{array}{c}\text { Tree-groundsel } \\
. .\end{array}$ & .. & Baccharis halimifolia . & .. & & 30 & & 12 \\
\hline $\begin{array}{l}\cdots \\
\cdots\end{array}$ & & Coprosma robusta & .. & 10 & & & 6 \\
\hline $\begin{array}{l}\cdots \\
\cdots\end{array}$ & & lucida & .. & 16 & 29 & 40 & 25 \\
\hline $\begin{array}{l}\cdots \\
\cdots\end{array}$ & & Escallonia macrantha. & . & 10 & 20 & 33 & 12 \\
\hline $\begin{array}{l}\cdots \\
\cdots\end{array}$ & & Euonjmus Japonicus . & $\cdots$ & 10 & & $\begin{array}{ll}2 & 9 \\
2 & 9\end{array}$ & 12 \\
\hline$\cdots$ & & $\begin{array}{l}\text { E1æagnus Japonıcus } \\
\text { Buddleia globosa }\end{array}$ & $\cdots$ & $\begin{array}{ll}1 & 0 \\
1 & 3\end{array}$ & $\begin{array}{ll}2 & 3 \\
2 & 3\end{array}$ & & 15 \\
\hline Tamarisk $\quad .$. & .. & Tamarix gallica & $\begin{array}{l}\cdots \\
\cdots\end{array}$ & $\begin{array}{ll}1 & 3 \\
1 & 3\end{array}$ & 26 & $\begin{array}{ll}3 & 0 \\
3 & 9\end{array}$ & $\begin{array}{l}15 \\
15\end{array}$ \\
\hline European box-thorn & .. & Lycium Europæum & .. & 10 & 20 & 30 & 12 \\
\hline African box-thorn & 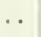 & Afrum & . & 13 & 23 & 36 & 20 \\
\hline . & & Pittosporum Ralphi & . & 10 & 23 & 39 & 35 \\
\hline Karo & .. & crassifoliu & um & 10 & 20 & 36 & 35 \\
\hline Matipou, Tawhiri & .. & Buchanan & nii & 10 & 20 & 3 & 40 \\
\hline Lace-bark, Whau-whi & & Plagianthus Lyallii & .. & 10 & 20 & 3 & 40 \\
\hline Elder & 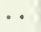 & Sambucus nigra & . & 13 & 23 & 36 & 25 \\
\hline Ngaio, Kaio & & Myoporum lætum & . & 13 & 26 & 39 & 35 \\
\hline Goat willow .. & .. & Salix caprea $\quad$.. & . & 16 & 30 & 46 & 30 \\
\hline $\begin{array}{l}\text { New Zealand Fuchsi } \\
\text { Kotukutuku }\end{array}$ & & Fuchsia excorticata & & 13 & 26 & 39 & 45 \\
\hline Cabbage-tree, Ti & .. & Cordyline australis & $\cdots$ & 16 & 30 & 46 & 40 \\
\hline Broadleaf, Papauma & .. & Griselinia littoralis & . & 10 & 19 & 26 & 50 \\
\hline Southern Rata & .. & Metrosideros lucida & - & 09 & 13 & 19 & 60 \\
\hline Alder $\quad \because$ & . & Alnus glutinosa & . & 10 & 23 & 39 & 60 \\
\hline Prickle-cone Pine & .. & Pinus muricata & . & 16 & 30 & 46 & 50 \\
\hline
\end{tabular}

A few practical comments as to the various groups of plants in the above list may be of value.

MarraM-Grass. - The shel ter attainable depends not so much on the beight of the plants as on the accumulation of sand. Thus, in three years, at Karitane, marram has raised a barrier $8 \mathrm{ft}$. high, rivalling in this way the quickest-growing shrubs. 
New Zealand Flax has proved one of the hardiest and best shelterplants of moderate height.

LUPIN and TREE-MALLOW.-For rapidly effective temporary shelter in our district these shrubs are unequalled, but they are comparatively short-lived, though the Lupin will keep on resowing itself and thriving for a long time. Both make large demands during their period of rapid growth on the water and salts in the soil, and thus tend to check the growth of other shrubs placed too near them. The Lupin does not rob the ground to so great a distance as the Mallow, will flourish in almost pure sand, and has the further advantage of storing up additional organic matter in the soil. It must be borne in mind that when the windward side of the screen is composed of Mallow or Lupin planted close up to permanent shrubs, the latter are left bare on the death of the former for a number of feet above ground-level, and are then apt to suffer severely from the effects of wind whistling through them. In spite of these objections no shelter has proved more useful at Karitane than Lupin and Mallow when used judiciously. A fringe of either or both placed a sufficient distance away from other shrubs is invaluable.

VERONICAS.-These may be planted in the order named, and will then form a dense inclined plane from windward to crest. $V$. Diffenbachii and $V$. elliptica are especially hardy, and if planted about $2 \mathrm{ft}$. or $3 \mathrm{ft}$. apart soon come together. It will be noted that the height attained by $V$.elliptica is only $3 \mathrm{ft}$. $3 \mathrm{in}$. at the end of three years; but this applies only to the outside fully exposed row, the second less exposed row attaining to $9 \mathrm{In}$. higher, and the third row to a height of $5 \mathrm{ft}$. If limited to one kind of plant for the rapid and economical formation of a dense permanent shelter-screen up to $12 \mathrm{ft}$. in this district I should choose this shrub. Cuttings can be propagated by the thousand with a minimum of trouble, and the young plants need no protection or shelter of any kind when placed in their permanent positions. Stray plants of Veronica elliptica form an indigenous growth here almost to the water's edge, on cliffs fully exposed to the south-west wind laden with sea-spray. Under these conditions it is a dwarfed gnarled shrub not exceeding $6 \mathrm{ft}$. high, with a trunk 6 in. through. Other hardy Veronicas, such as arborea, Colensoi-major, \&c., do well here, and I have dwelt specially on the merits of $V$. elliptica simply because it appears to us to be the most suitable for extended use in the formation of permanent windcreens.

The SEnecios and Olearias named have all proved very hardy, are for the most part easily propagated by cuttings, and make quick growth. Unfortunately, individual plants of both genera are more or less iiable to sicken and die suddenly when still young and apparently in full vigour. This liability to disease renders it undesirable to trust solely to these shrubs in any locality. The thickets and groves of robust old trees and the isolated specimens seen at Stewart Island and elsewhere show that the Senecios and Olearias are not shortlived under suitable circumstances. The most valuable in this district are Senecio rotundifolius and Olearia Traversii. As the latter tends to outgrow its strength and to flower excessively it should be clipped back every year or so. Further, it is well to plant some shrub such as Veronica elliptica or Senecio rotundifolius to windward, because the lower part becomes bare in a few years. The hardier Senecios and Olearias have proved not only indifferent to wind, but are found to be more healthy and vigorous when exposed. Like the Veronicas, well-rooted cuttings may be planted out directly into exposed situations without being sheltered.

Escallonia macrantha.-Among exotic shrubs this has proved one of the hardiest and best, but propagation is much more troublesome than in the case of the foregoing plants, and it is less easy to establish.

ELÆAGNUS JAPONicUS and EUONYMUS JAPONICUS are in all respects excellent pioneers.

Pittosponuns and Coprosmas. - The best of these, such as P. Ralphi and C. lucida, make rapid growth, and are thoroughly hardy and reliable. 


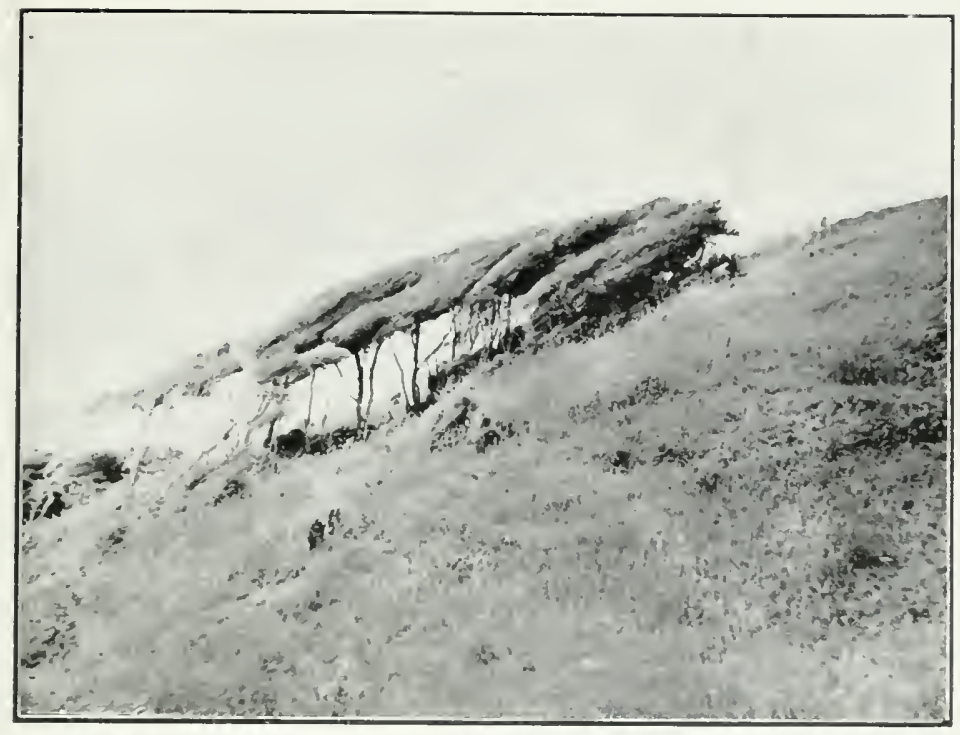

HILLSIDE AT PORIRLA NWEPT BY STRONG PREVAILIAG WINIS, SIHOWING 1 CLIMI OF IIVIKI-BLSHES SHORX TO THE GROLND-SLOPE.

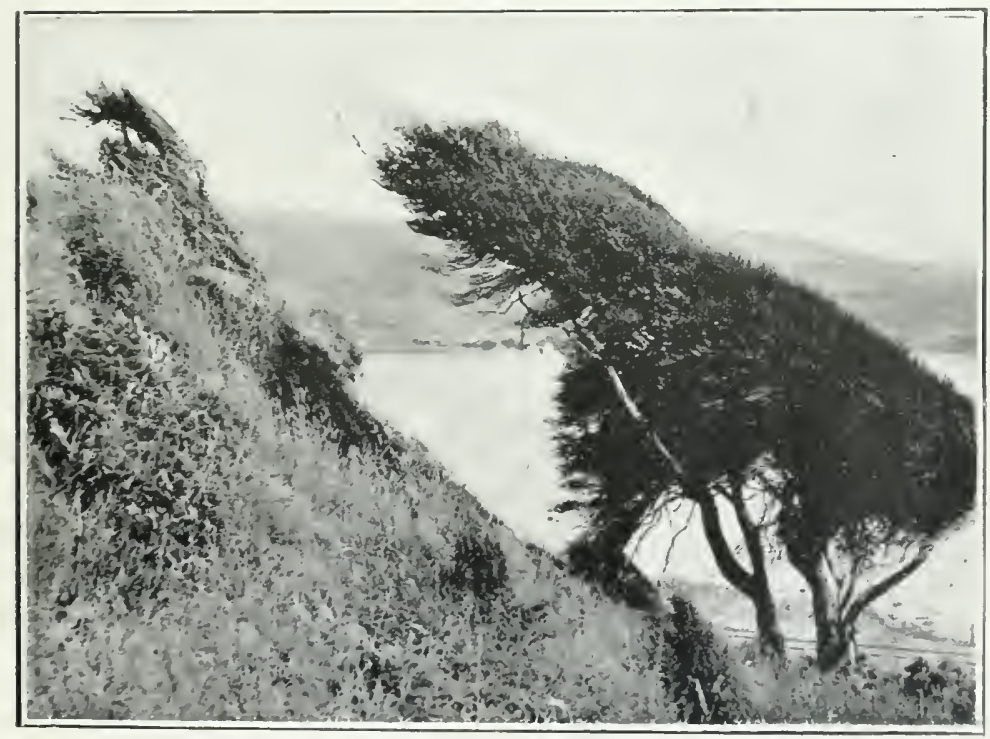

IHLLAIDE AT JORIRTA SWFPT BY STRONG PREYAHING WINIS, SIOWING

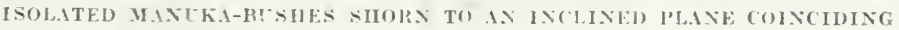
WITH THF, G?O[`NU-SI.OPE. 

Cordyline acSTRalis.-Nothing we have tried, with the exception of Olearia Traversii, outstrips the Cabbage-tree in rapidity of growth, and the extreme ease of propagation by seed renders it one of the best trees for extensive planting at the seaside.

GOAT-WILLO and Box-THORx have both proved very hardy, quick.growing, and satisfactory, and the facility of propagation by cuttings renders them suitable for extensive use.

The BROADLEAF, on account of its hardiness and permanence, is one of the most desirable seaside shrubs, and we find that its growth in fairly good soil is not so slow as is generally supposed. We consider it a good pioneer to plant on the windward side of any shrubs of doubtful permanency, such as some of the Senecios and Olearias. The taller forms of either of the latter groups, of course, outstrip it in rapidity of growth and will afford immediate protection, but the Broadleaf can be relied on for ultimate shelter and continuous steady growth.

BACCHARIS HALIMIFOLIA makes very rapid growth in this district, and promises to be valuable on account of its ability to grow in almost pure sand and in situations liable to frequent flooding by salt water. Its rapid herbaceous growth inclines one to think that, like many of the Composita, it may not prove to be very long-lived.

The NGaIo, which is so valuable in the North, and of which there are many good adult specimens in the district, has proved almost a failure owing to the severe cutting-back of young plants by frost, and the ravages of aphides in summer. When it is added that our adult trees are much infested by borers, and are many of them dying from this cause, it will be realised that the Ngaio is of doubtful value here.

The TaUpata (Coprosma Baueriana) and KARAFA are too much cut by frost to make any satisfactory progress as pioneers.

The PoHutukawa is killed outright in cold winters.

Of lofty evergreen trees the Pinus muricata and hardier Gums promise to serve our purposes best. Some of the hardier wattles are expected to quickly afford good shelter, both as shrubs and trees. Cupressus macrocarpa and Pinus insignis grow fairly satisfactorily, but are more cut by the sea-breezes than P. muricatas.

No doubt some of the plants we have tried in this district would make more rapid growth elsewhere, but on the whole I think the tendency would be in the reverse direction. Our soil is decidedly above the average, and in many coastal situations stresses of weather are more severe than at Karitane. I know that some of the shrubs mentioned make comparatively slow growth under conditions apparently differing very little from our own, but, allowing for local idiosyncracies, the list will, I am satisfied, be found generally applicable except in the far North. A word of caution as to ploughing exposed seaside ground is perhaps desirable. If the soil is light and fully exposed the danger of baving the soils carried away during a strong gale must always be borne in mind.

I enclose some photographs illustrating wind-shearing, and trust that these will make it clear how much more rapidly a high screen can be grown if it is made of sufficient width to furnish an inclined plane of twigs and foliage rising gradually from windward to leeward in respect to the prevailing sea-breeze.

$$
\begin{aligned}
& \text { Yours, \&c., } \\
& \text { F. TRUBY KiNG. }
\end{aligned}
$$

H. J. Matthews, Esq., State Forestry Department, Dunedin. 


\section{CHAPTER XV.}

\section{STREET TREE-PLANTING}

कृष

E annually increasing number of inquiries made by Borough Councils in regard to the work of street-planting has suggested the writing of the following short chapter on this subject, in the hope that it niay be of some assistance in carrying out this very desirable work.

The planting of trees along the margins or centres of streets is a matter of great importance not only on account of the cheerful aspect produced by their colour and the advantage gained by their shade, but also from a sanitary point of view, as it is well known that the presence of healthy foliage is a considerable factor in the purification of the atmosphere.

In order to secure the favourable opinion of the public regarding street-trees the first and principal aim must be to succeed in the object in view-viz., to line our streets with trees which from their nature are suited to withstand the dusty atmosphere of towns, and which will grow with reasonable rapidity and prociuce an abundance of healthy foliage that will remain in good condition until the autumn is well advanced. These are the conditions which the public have a right to expect, and for which they are called upon to pay in the shape of rates. Since, therefore, the planting of streets devolves generaily upon pubic bodies, it seems necessary to employ competent persons to carry out the work. Too often it is placed in the hands of surveyors, who as a rule have not the necessary knowledge to skilfully direct tile workmen employed; consequently failure is almost certain - at all events, only poor results are obtained from the outlay. The principal drawback to the success of street-planting is the same that has retarded other undertakings in the direction of arboriculture-viz., want of knowledge as to the conditions of successful growth, and the absence of care and attentiou subsequent to planting, by which alone obstacies presented by naturally unfavourable surroundings can be overcome.

It is safe to say that most people regard tree-planting as being as simple and easy a matter as tree-felling: all that has to be done is to dig a hole, put in your tree, and fill up the hole again. If under ordinary conditions of growtl a vast deal more is requisite to successful planting than sticking the tree into the ground right end up and letting it take its chance, how much more obvious is the need of attention and proper precautions both at and subsequent to planting when the influences and surroundings of crowcied 


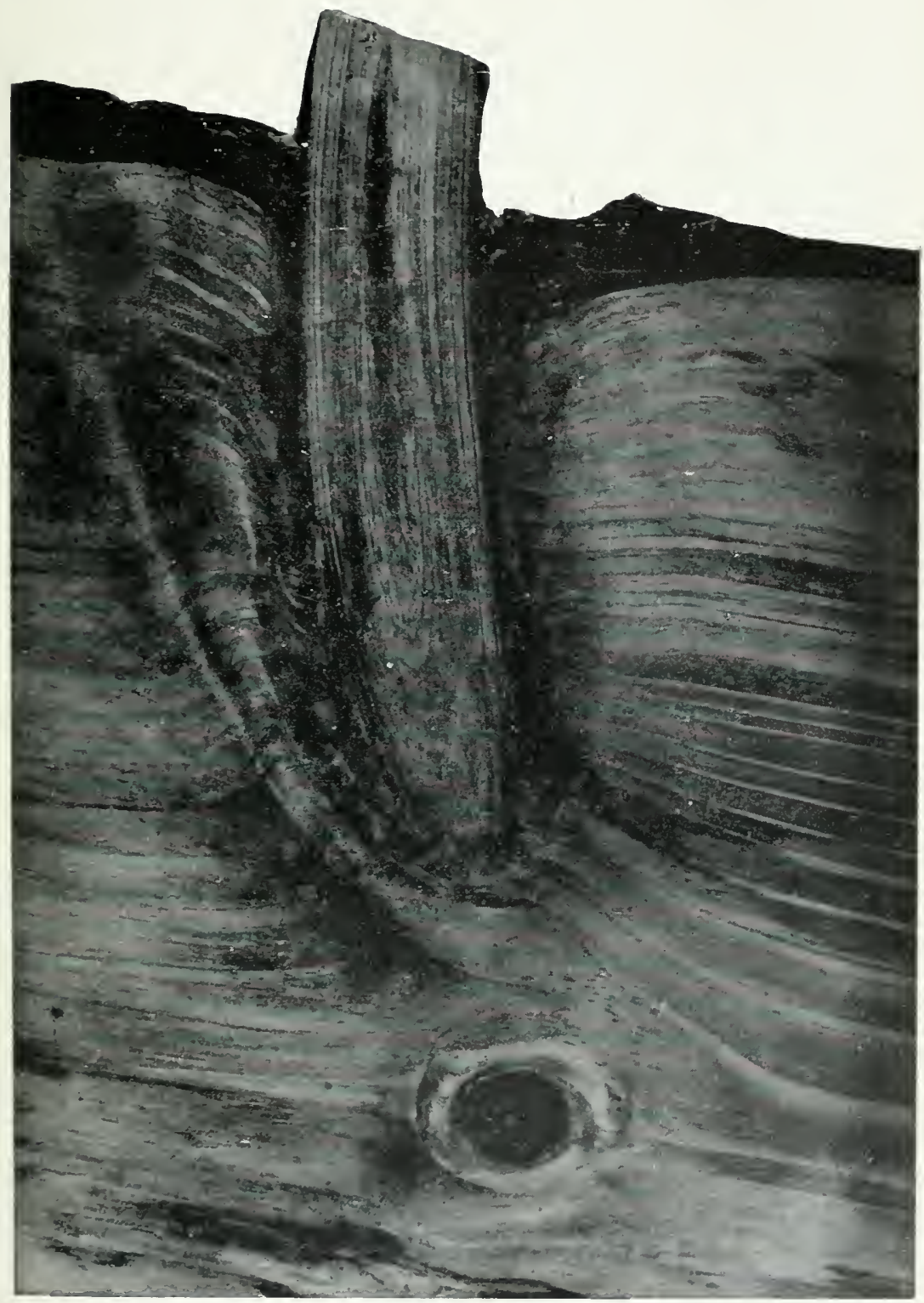

l.ONGITLDINIL SECTION OF AUSTRIAN PINE (PINCS AUSTRIACA).

I'late 35.]

[Face p. 70. 

thoroughfares upon the tree's growth have to be taken into account. Yet how often does failure result from the fact that trees are merely stuck in and left exposed, not only to struggle against unfavourable conditions of soil and moisture, but to the chances of street accidents! It is of first importance that the tree has abundance of good rich soil in contact with its roots from which to draw nourishment, as the soil of the street is usually hard and dry, and largely composed of elements little aclapted for the support of vegetable life. When the tree has attained a firm foothold it will he able to extend its roots into such uncompromising soil, but in planting it should have sufficient good rich soil to give it the necessary sustenance in its earliest stages.

Few persons understand that it is through the hair-like fibres which radiate from the large roots that the tree absorbs nutriment from the soil. In digging up trees for transplanting a large proportion of these are necessarily detached--especially those at the extremities-and the absence of these fibrous roots is apt to be regarded as a matter of little consequence so long as sufficient of the main roots remains intact. Trees are frequently planted from the roots of which nearly all the fine fibres have been torn away, and the larger the trees the fewer of these hair-like filaments are likely to be saved in removal, as they grow in the greatest profusion farthest from the tree and from the larger roots. This is one reason why the difficulty of safely transplanting trees increases with their size. Exposure to the air, and possibly to the sun or a drying wind, causes the fibrous roots to quickly lose their vitality. Probably no course results in more failures than the planting of trees which apparently have plenty of roots, but from which the fine fibres have either been torn away or allowed to wither through exposure to the atmosphere. When the capacity of a tree for extracting moisture from the earth is diminished by the loss of a proportion of its roots, it is necessary to restore the equilibrium between ab)sorption and evaporation by proportionately diminishing the expanse of foliage by pruning, otherwise the amount of moisture which the small remaining quantity of root-fibre is able to absorb will be insufficient for the supply of leaf-surface, and the result will be decreased vitality, followed by death.

\section{Staking Strent-trees.}

This provision should never be omitted immediately after planting. When tree-guards are used, a loose collar of canvas or other strong material should be put round the main stem at the same height as the top of the tree-guard. To this may be attached three short lengths of wire or clothes-line, and the other ends may be made fast to the top of the tree-guard. When tree-guards are not used, it is a good plan to drive in one or more wooden stakes at an angle of $45^{\circ}$ (with the lean towards the direction of prevailing winds), and attach the tops of these to the main stem about $6 \mathrm{ft}$. up. Some soft and pliable material should be wrapped around the 
stem to prevent chafing, and this should be sufficiently slack to allow for increase of growth during the first season following planting, after which the stake can be removed.

\section{Pruning Street-trees.}

Much injury is intlicted upon street-trees by ignorant and careless pruning. Limbs are frequently cut off, leaving a projecting stump instead of severing close to the trunk, with the result that the projection gradually rots away, and decay is communicated to the heart of the tree.

After pruning, the wounds should be painted over with Stockholm tar or paint - a precaution against disease which is seldom adopted. The most important point to be remembered in pruning street-trees is to carefully preserve the main stem during all stages of growth. No branches should be allowed to remain at a lower height than $10 \mathrm{ft}$. from the surface to the ground, as any such will only be broken or destroyed by traffic. When the head becomes too thick, top-heavy, or is spreading beyond its legitimate limits, it is a simple matter to reduce its branches, remembering always to cut them close to the fork from which they spring.

\section{Tree-guards for Street-trees.}

There is little use in planting trees along streets unless they are protected from the injuries to which in such localities they are continually liable, especially from the attacks of animals and thoughtless or mischievous boys. Circular wire-netting guards, $6 \mathrm{ft}$. in height and $3 \mathrm{ft}$. to $4 \mathrm{ft}$. in diameter, seem to be the most effective means of affording the necessary protection. Four or more uprights of angle or tee iron, and from three to four circular bands of light iron firmly riveted to the uprights, make the neatest and most lasting guard, while the cost is only slightly more than that of the perishable wooden structures so frequently seen in our towns. Street-trees are often irreparably injured through chating against the guards, and constant attention must be given to prevent damage from this cause until the trees are sufficiently strong to withstand swaying by the winds, in accordance with the directions given later.

\section{Trees suitable for Street-planting.}

There is no more pleasing effect in street-tree culture than a long shady avenue of the same variety of trees trained with a view to uniformity, whilst any intrusion of another kind, differing in hue or foliage, is like a discordant note in a strain of music. In many of our towns, for instance, may be seen on the same street Poplars, Elms, Oaks, Chestnuts, Planes, and Birch, all in different stages of growth; while occasional blanks and wide gaps occur where failures have not been replaced, producing much the same effect as the juxtaposition of old-fashioned lean-to shanties with modern buildings of two or three storeys high. It would be a great improvement 


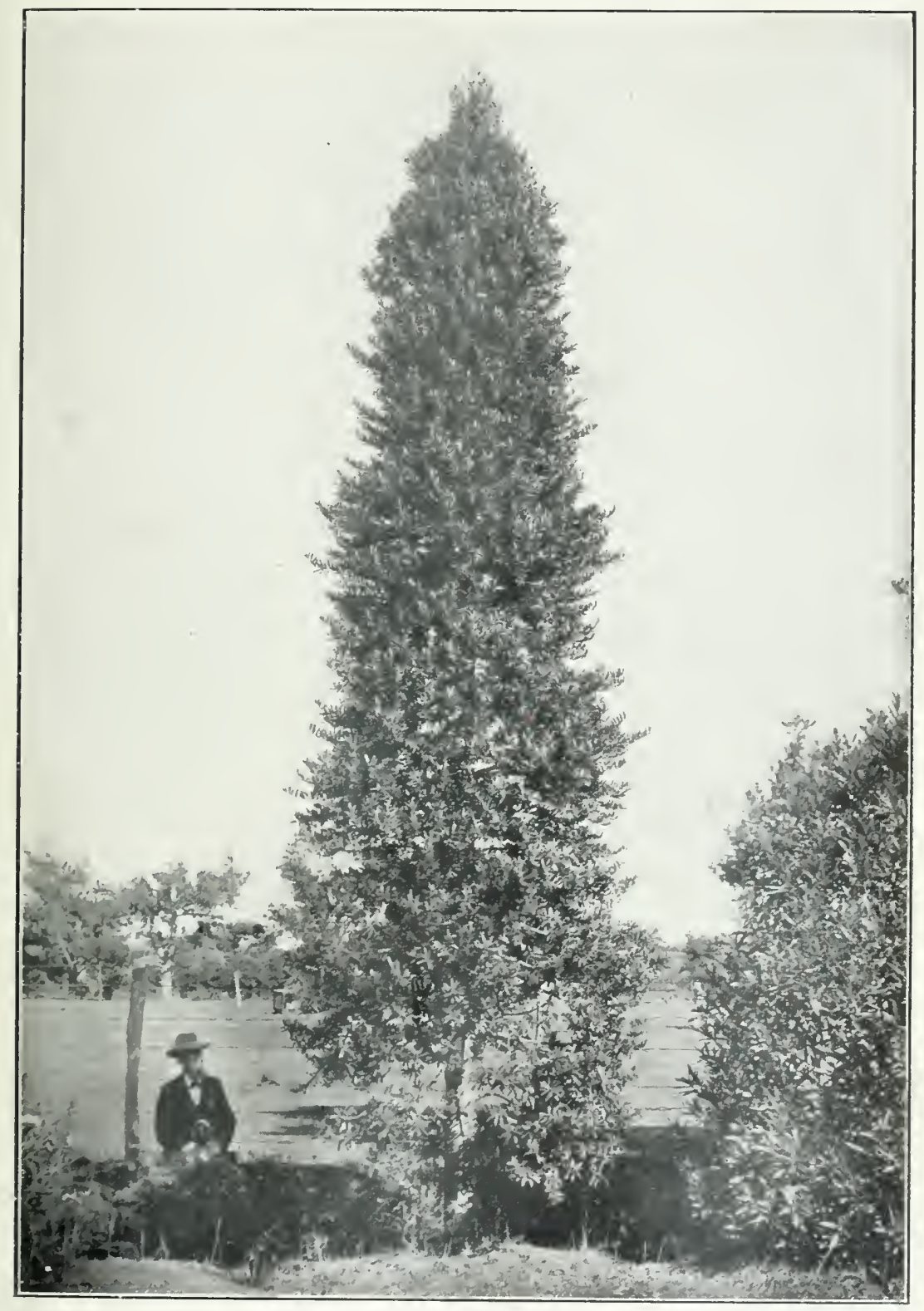

Plate 36.」

SPECIMEN OF IOLNG EACRI.

Fice p. 72. 

to have rows of Planes on one street, Chestnuts on another, and so on.

The interval between the trees must be decided according to the species of tree dealt with, those of a spreading habit requiring much more space between individual trees than those of a more upright growth. Roughly, half a chain may be said to be the correct distance for most trees, but this distance will vary a few feet either way according to the length of each building-block. This distance can easily be determined by putting in pegs a quarter of a chain from each end of the starting-point-e.g., from the kerb of the street running at right angles to the one being planted-and dividing the distance between these two pegs by $33 \mathrm{ft}$. or thereabouts. No tree should be nearer the kerb-line than $6 \mathrm{ft}$, otherwise its roots will in time cause the water-table to become elevated opposite each tree, forming a series of miniature dams along the whole street-line.

As to the preferable varieties for street-planting, there is a wide difference of opinion, and choice also largely depends on local conditions. Generally speaking, the Oriental Plane is the most popular in this colony, where it thrives under almost all conditions of soil and climate. It is, however, best to select those species which have large leaves, as in these the spaces between the branches are wider; so that while in summer the large leaves afford a pleasant shade, in winter, when the trees are bare, both the sun and wind have free access to the street below; but small-leaved trees, such as the Silver-birch, having closel branches and an abundance of twigs, even in winter cast a shade which is undesirable, as it keeps the street damp.

The following trees can be recommended as suitable for most localities, and further particulars regarding these will be found in the alphabetical list in another part of the volume:-

The Oriental Plane is unquestionably the best of all the Planes, both for shade and for handsome foliage. It forms a round and rather dense-headed tree, seldom exceeding $60 \mathrm{ft}$. in height, with a comparatively short but massive stem, which soon divides into several robust arms, spreading horizontally to a considerable distance. This horizontal growth (which appears more marked as the troe advances in age) is apt to interfere with vehicle traftic unless the main stem is kept free of branches to a considerable height during early youth. In many of our towns this precaution has been neglected, and it cannot be rectified in after years without destroying the shape of the tree. Of late years some fungoid growth has attacked this tree during the early summer. This pest is more noticeable in the North Island, where many fine trees have been almost destroyed by its ravages. As with all large trees, any attempt to combat the disease by spraying is out of the question. For inland towns in Canterbury and Otago it is too tender to withstand the occasional severe winters experienced. An instance is 
recolded near Dunedin of several hundred six-year-old well-grown trees of this species being killed outright by the winter of 1902 . This was not due to intense cold through frost, but to a blighting wind, which is frequently more severe on tree-growth than actual lowness of temperature. All the Planes are easily increased by cuttings taken from healthy one-year-old wood on the sunny side of the tree. These should be from $18 \mathrm{in}$. to $2 \mathrm{ft}$. long, and where possible a heel of the previous season's wood should be left at the base. Plant closely in moist sandy loam to about two-thirds of their depth. If all but the three top buds are removed these will make strong shoots during the summer. Only the straightest and stoutest one should be left, the remainder being cut off close to the stem.

The American Plane (Platanus occidentalis) is in many respects similar to the foregoing, but is usually larger and nore upright. It may easily be distinguished from its congener by the red leaf-stalks and the large, smooth seed-balls.

The Tulip-tree (Liriodendron tulipifera) is one of the best trees to withstand the smoke and dust of towns. The remarkable fourlobed, truncate leaves render it exceedingly ornamental, while it is fast-growing and not particular as to soil so long as there is no stagnant moisture. Usually raised from seed.

Catalpa spcciosa can be recommended for street-planting on account of its large spreading crown and its immense leaves. It grows quickly, and is easily increased from seed. One desirable feature in regard to this tree is that should any accident befall it the stem can be cut off at the ground and a strong shoot will spring up from $8 \mathrm{ft}$. to $12 \mathrm{ft}$. in length during one season, which shoot soon takes the place of the original stem. This tree should be planted in. sheltered places only.

The Lime (Tilia Europaa) as an avenue or street tree has certainly few equals. Windy localities do not suit it, but in sheltered towns its contour and its pleasing shade render it worthy of special recommendation. The Lime is best increased by layers, although seed-bearing trees are not now infrequent in the colony. Strong deep clayey loams suit it best.

The Horse-chestnut (Asculus Hippocastaneum) may be seen at its best on the banks of the Avon, at Christchurch. Like the Lime, it requires shelter, not only on account of its large leaves being easily broken off, but owing to the brittle nature of its branches, the lower ones being usually pendulous, with upturned ends. The Horse-chestnut will stand any degree of cold experienced in New Zealand. Pich loamy deep soils suit it best. It is easily raised from seed, which should be sown as soon as ripe. There are about twelve species of Horse-chestnut known, and each species has numerous varieties, many of which have exceedingly beautiful flowers-white, pink, yellow, and red being the principal colours. 


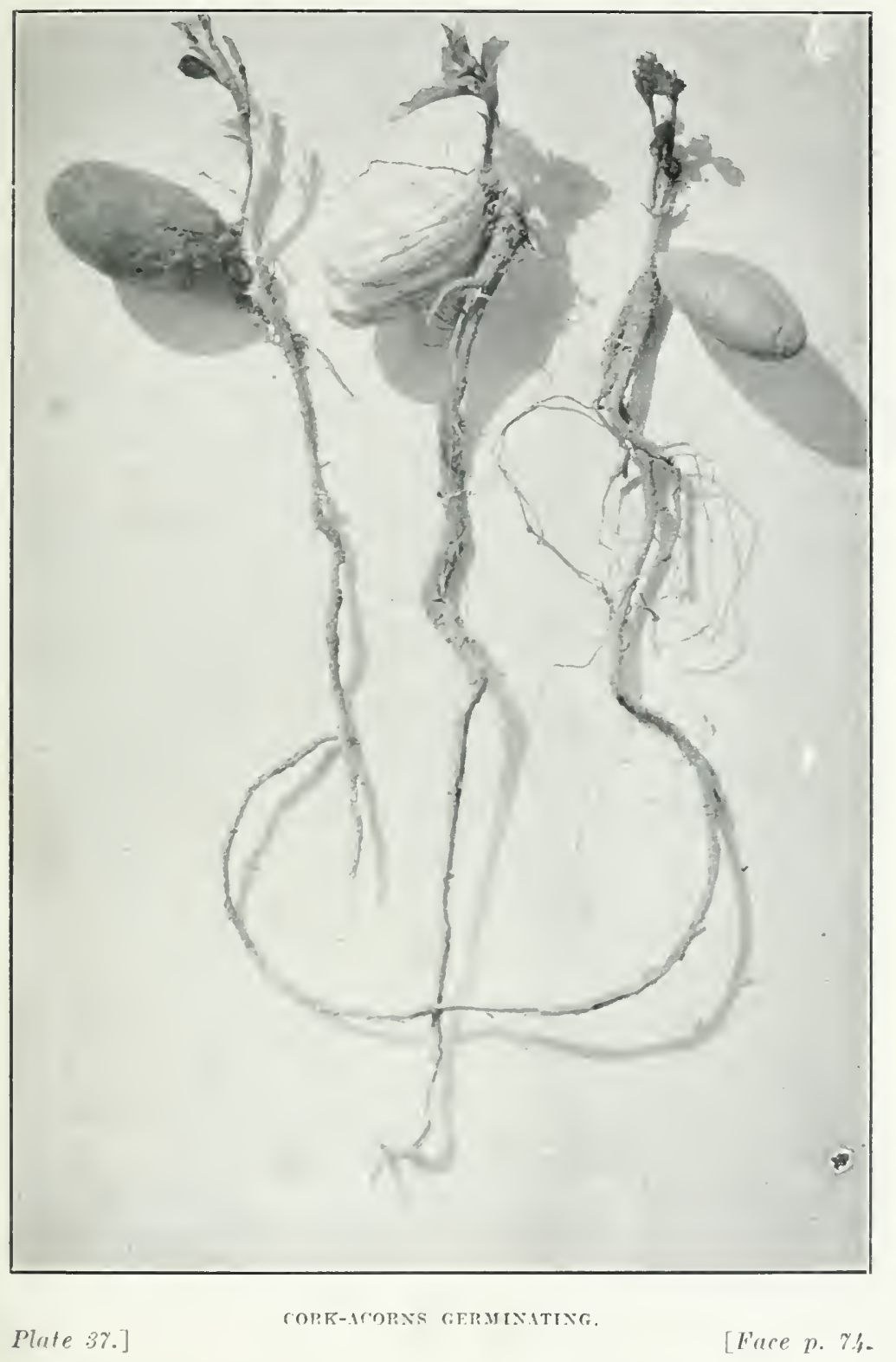



The common Sreamore (Acer pseudo-platanus) is suitable only for planting in very wide streets, owing to the immense spread of its branches and its rapid growth. Young saplings should be grown on to a height of $12 \mathrm{ft}$. to $14 \mathrm{ft}$., and kept free of branches until this height is reached, otherwise the horizontal limbs will eventually interfere with traffic. No tree is more easily raised or transplanted, or is less particular as to soil, than the Sycamore.

Eight other species of $A c e r$ (mentioned in the alpbabetical list of trees) are also suitable for street-planting. Many of these are remarkable for their ornamental autumn foliage, whilst all are thoroughly hardy, easily grown from seed, and bear transplanting well.

The English Elm (Olmus campestris) should also be confined to wide streets, owing to its huge dimensions. Its tendency to throw up suckers is, however, against its popularity as a street-tree.

Ulmus montana (the Mountain, Scots, or Wych Elm, distinguished from the English Elm by its larger deeply-serrated leaves) does not produce suckers. It is of much quicker growth than the English Elm, and is usually of straggling habit until its leader becomes fairly developed. Seeds are not produced freely in the colony by any of the Elms, owing probably to the absence of a particular species of moth which assists in the fertilisation of the flowers. Layering will therefore be found the best means of propagation.

The cornmon Ash (Fraxinus excelsior) is one of the most graceful and beautiful trees for street-planting where ample space can be afforded for its full development. Moisture is essential to its success, but an excess of this should be avoided. This is one of the latest trees in corning into leaf in spring, and for this reason it is not a favourite for street or avenue planting.

About forty species of Ash are in cultivation, besides innumerable varieties of the common Ash, the best being the Goldenbrancher, Variegated-leaved, and Weeping varieties. All species of Ash are raised from seed, which must lie in damp soil or sand for twelve months previous to sowing.

The Spanish or Sweet Chestnut (Castanea satıva) is a highly ornamental street-tree of large growth. Few trees are so striking in appearance during the autumn, when its leaves turn to a rich golden yellow. The Chestnut springs readily from the root-a decided advantage shouli the stem be damaged by accident. Gravelly, open soils seem to suit it best, although it thrives on almost any land that is not wet. It is raised from seed, sown as soon as ripe.

The common Birch (Betula alba) makes an excellent street-tree where space is limited, although, owing to its twiggy growth, it is not very suitable for low-lying damp localities. Few trees will succeed on a greater variety of soils than the Birch, while its hand. some and graceful appearance renders it a general favourite. Some 
forms assume a pendulous habit, which adds greatly to their ornamental character. The Birch is thoroughly hardy in any part of the Islands, and can be raised from seed (collected locally) at a minimum of skill and cost. A purple-leaved variety is fairly common in ornamental plantations. This can be raised either from layers or by grafting.

Paulownia imperialis is a large-leaved deciduous tree of rapid growth, producing violet-coloured and violet-scented flowers. It is not particular as to soil, and attains a noble stature. Like all trees which produce large leaves, it must be planted in sheltered positions. Few trees excel the Paulownia for avenue-planting.

The Japanese Cherries (Prunus pseudo-cerasus) attain dimensions which make them suitable for avenue-trees, while their wealth of flower in early spring makes them striking and delightful objects. Travellers who have visited the Cherry groves when in bloom in the neighbourhood of Tokio never weary of telling of the glorious sight. The Cherry would in all likelihood be unsuitable for town-planting proper, but for forming avenues in public parks and along suburban roads it would probably be unsurpassed.

Many more trees are available for street-planting, but the principal kinds recommended are those mentioned. The remainder will be found in the alphabetical list of trees.

\section{CHAP'TER XVI.}

\section{REPLANTING WITH NATIVE TREES.}

$x^{\circ}$ EARLY every visitor to the State nurseries asks the question, "Why don't you plant native trees?" The answer is, shortly, "Because it won't pay." Some explanation of this apparent neglect of our own timber-trees seems necessary. In consequence of nearly all New Zealand timber-trees being surface-rooters their adaptation for general afforestation in open lands is practically prohibited through the damaging effects of exposure to sun and wind. The principal exceptions are Totara, Kowhai, Puriri, Broadleaf, and three varieties of Fagus, all of which are easily raised from seed (or cuttings), transplant well, and make comparatively fast growth up to a certain age, when their further progress is almost unnoticeable. Other trees of commercial value, such as Rimu, Rata, Miro, Matai, Kahikatea, Kauri, Kawaka, and Silver-pine, have been suggested by experts and others as suitable for extensive planting, especially on the pumice lands of the North Island; but it is feared such recommendations have been made through want of practical knowledge as to the special treatment necessary for their 


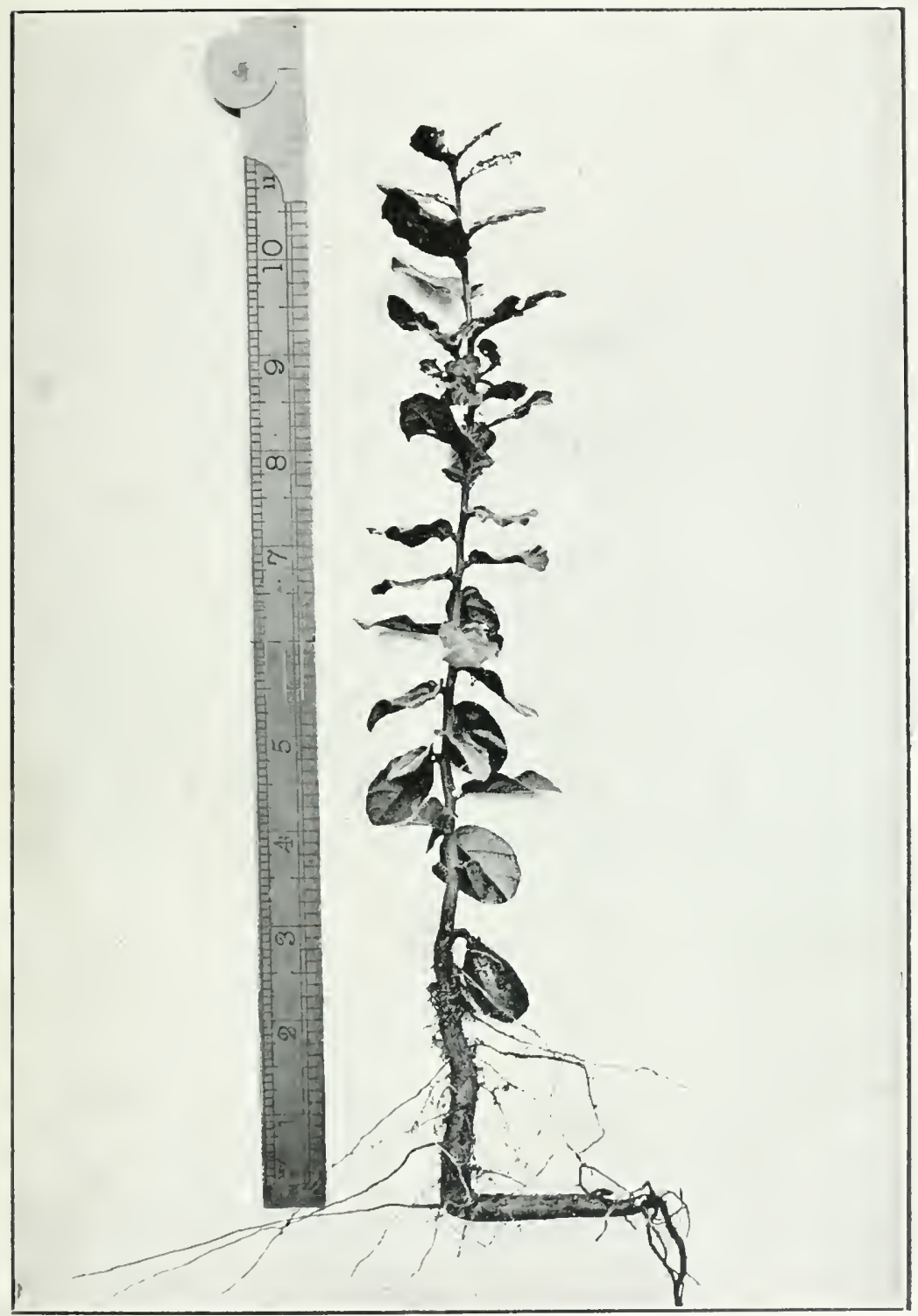

Plate 38.]

[Face p. $\% 6$. 

snccess. All the varieties mentioned require considerable shade from the seedling to the adult stage, and this can only be afforded by planting them anongst partially cleared forest lands, where the natural undergrowth provides the requisite amount of protection. The prevailing class of underscrub (or second growth) in our "bushes" is unfortunately of exceedingly rapid growth compared with that of the trees under notice, so that unless clearing is frequently undertaken to prevent the crushing-out of the permanent trees by their natural protection they would be suppressed within a comparatively short time. This work would be very costly, owing to the necessity of continual clearing over a long period, this period being limited only by the permanent trees reaching such a height above the undergrowth as that their leading stems would be free from further suppression, while their sensitive roots would still hare the necessary protection from the damaging influences of exposure to both sun and wind.

In connection with the planting of the aforementioned trees for timber purposes, it must be considered whether this would be a successful undertaking from a financial point of view. Our knowleage of the age of the mature trees of this class, although limited, is nevertheless probably sufficient for present purposes. The following table, taken from the "Forest Flora" and the late Mr. W. N. Blair's "Building-materials of Otago," show the approximate ages of our commonest timbers :-

Name.

Rata

Broadleaf ...

Pokaka ...

Miro

Totara

Matai

Kahikatea...
Manuka $\quad .$.

Approximate Ages.

Years.

The ages of the above-mentioned trees were ascertained by counting the number of annual growths on recently cut sections of the trunks. This method of arriving at an approximate estimate of the age of a tree, although accepted by the leading authorities on vegetable physiology, has been questioned only by the late Mr. Perrin, who states in his report (page 39): "I do not agree with the great-age theory as applied to the Kauri and other New Zealand timber-trees. . . . I was only, however, three days in the Kauri forests, so that I tremble at $\mathrm{my}$ own temerity in thus attacking fables of hoary antiquity." The opinions of such able experts as Blair, Balfour, Buchanan, Kirk, and others who have frequently made use of the annual-ring system in estimating the ages of trees seem preferable. 
Mr. J. W. Hall, of Parawai, Thames, has devoted considerable time to the cultivation of native trees during the last thirty years, and the results attained in the growth of several species are as follows :-

\section{Name.}

Kauri (Agathis australis) ...

Püriri (Vitex littoralis) $\quad \ldots$

"Iatai (Podocarpus spicatus)

Totara (Podocarpus totara)

Miro (Podocarpus" ferrugineus)

Kahikatea (Podocarpus dacrydiodes)

Rimu (Dacrydium cupressunum) ...

Käwaka (Libocedrus Doniana)

Tanekaha noides)

Tanekaha

(Phyllocladus trichoma-

(Phyllocladus

trichoma-

\begin{tabular}{|c|c|c|c|}
\hline Girth. & Height. & $\begin{array}{l}\text { When } \\
\text { planted. }\end{array}$ & $\begin{array}{l}\text { Age in } \\
\text { Years }\end{array}$ \\
\hline Ft. in. & Ft. in. & & \\
\hline 11 & 0 & 1877 & \\
\hline 111 & 340 & 878 & \\
\hline $\begin{array}{cc}4 & 4 \\
9 & 1\end{array}$ & 390 & 2 & \\
\hline $\begin{array}{rr}2 & 10 \frac{1}{2} \\
0 & 71\end{array}$ & 300 & 18 & \\
\hline $\begin{array}{ll}2 & 9^{2}\end{array}$ & 420 & 1873 & 2 \\
\hline 24 & 390 & 1873 & 2 \\
\hline 11 & 160 & 1876 & 2 \\
\hline 16 & 350 & 1876 & 2 \\
\hline 110 & 330 & 1873 & 28 \\
\hline 111 & 350 & 1874 & 2 \\
\hline 16 & 220 & 1878 & 2 \\
\hline 111 & 240 & 1875 & 2 \\
\hline 17 & 320 & 1876 & 2 \\
\hline 19 & 300 & 1878 & 23 \\
\hline
\end{tabular}

All the above were planted as seedlings of an average height of $6 \mathrm{in} .$, and the measurements were taken on the 7th August, 1901.

These records, although of considerable interest, are of little value in determining the approximate age when any of the species will be matured for felling. As before mentioned, comparatively rapid growth is made in their early stages up to a certain point, when further development is almost imperceptible.

Blair gives the approximate age of a mature Rimu as from 400 to 650 years, a Totara as from 470 to 800 years, a Kauri as from 600 to 3,600 years, and a Kahikatea as from 370 to 600 years. Accepting these figures as a rough estimate, or even allowing one-half the periods he mentions as a fair average for the maturing of any one of the species named, would the Forestry Department be justified in planting any of the above-named trees with a view to providing for the wants of the future, when two or even three crops of exotic trees-such as Gak, Larch, Spruce, Oregon Pine, or Eucalypticould be produced within the same period that one crop of native trees would take to reach maturity?

Not only this, but it is well known that most of our native timbers are comparatively worthless to the sawmiller when, say, only 12 in. in diameter. All the exotic trees mentioned are, how- 


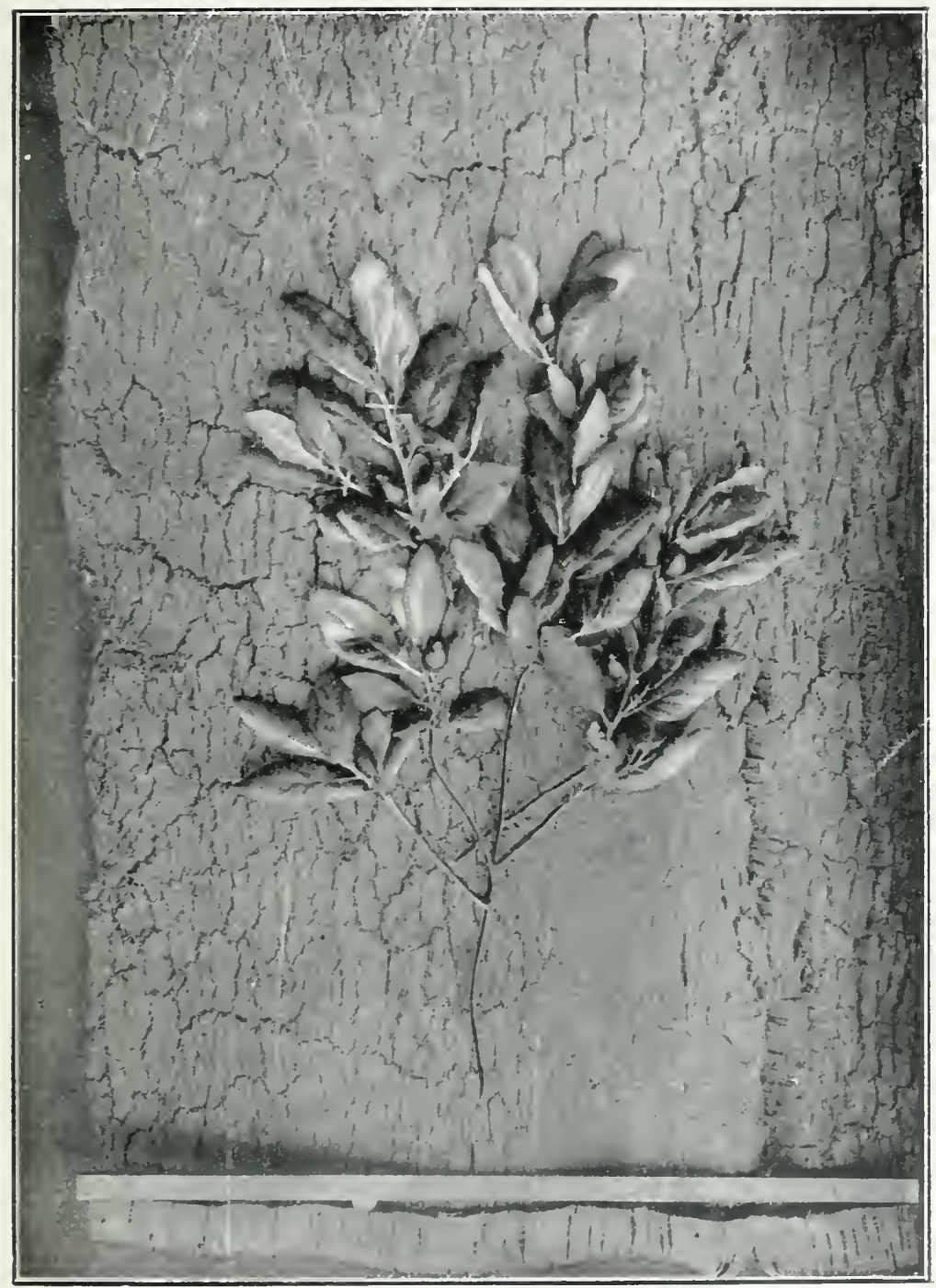

Plate 39.]

SFCTION OF CORK-B.IRK GROWX IN ACCKLAND.

[Face p. 78. 

ever, useful, either as fencing-posts, rails, sleepers, or for ordinary building purposes, when a comparatively small diameter only has been reached; and thus the necessary thinnings from such plantations can be utilised with profit. Such is not the case, however, with Rimu, Kauri, and other native trees. To produce marketable timber free from knots trees must be planted so thickly torether that the formation of side branches of a large diameter is impossible. When a too-crowdea state is reached thinning must be resorted to, otherwise in the struggle for existence they will interfere with one another to such a degree that all will be more or. less worthless through want of space for natural derelopment.

For what purpose, then, can the thinnings of an artificially formed native-tree plantation be ntilised? In the first instance at least 1,200 young trees must be planted par acre, but by the time maturity is reacher there will probably be only 100 of these remaining as the final crop. As already shown, these chinnings are of no commercial value (except perhaps as firewood), so that no less than 1,100 trees musi of necessity be wasted. No easily and cheaply raised exotic tree would be suitable to act as "nurses" to these, owing to their inability to thrive in that degree of shade and moisture necessary for our native trees; and even if a suitable "shade-bearer" could be found its rate of growth would be so much superior to that of the varieties composing the ultimate crop that they would practically take possession of the soil, as do all species introduced from the Northern to the Southern Hemisphere. Further, there is the attendaut labour in preventing the suppression of native trees by the undergrowth necessary for their establishment during, say, a period of forty years, the cost of which alone would render the proposal prohibitive.

Puriri, Totara, Fagus, and Kowhai are, however, being planted by the State in certain favourable localities and in comparatively small numbers, thus affording an opportunity of obtaining accurate data for future gruidance. The value of these timbers is unequalled for certain technical purposes, and from close personal observation it is tolerably safe to predict that they will produce useful timber within a century. 


\section{CHAPTER XVII.}

\section{CONIFEROUS TREES.}

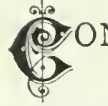

NSIDERABLE confusion exists in regard to the nomenclature (both scientific and vernacular) of coniferous plants. This is principally due to the frequent revision of the order by various botanists in accordance with their particular views on the subject, and to a less extent to the often meaningless local synonyms given in nurserymen's catalogues and gardening periodicals. In Great Britain and the colonies Pines are frequently called "firs," Firs are called "spruce," and Spruce "pines." With the object of assisting cultivators in discriminating between the various genera included in the natural order of Coniferce the following brief outline will, it is hoped, be of service :-

Coniferc, or cone-bearing, is the name given to a natural order of plants with resinous juice, scale-like or needle-shaped leaves, and both male and female flowers produced upon the same or different trees. With few exceptions (Larch, Bald or deciduous Cypress, and Maidenhair Tree) they are evergreen (so called), retaining their leaves from two to five years, and from ten or fifteen years in Araucaria imbricata. The stems or trunks of coniferous trees are usually cylindrical, straight, and tapering. The branches are commonly-always in the Araucaria, Fir (Abies), and Pine (Pinus) - produced around the trunk in whorls or tiers, and the intervals between these show the height the stem has made in successive seasons. Should a tree retain these from base to summit, its approximate age can be arrived at. The fruit-cone, berry, or drupe varies considerably in size - as large as a man's head in Araucaria Bidwillii, and about $2 \mathrm{ft}$. long in Pimus Lambertiana, while those of Retinospera are seldom more than $\frac{3}{2} \mathrm{in}$. in diameter. The shape is ovoid in many of the pines, and almost spherical in some of the araucarias. The colour of the cones varies in a remarkable degree, although the majority of the species are dull and unattractive. Abies Webbiana produces cones of a deep violet-purple, and the cones of $A$. nobilis are a bright pea-green. The seeds are produced singly in the Yew, Miro, Matai, Rimu, \&c.; in pairs in Abies, Pinus, \&c., attached to the cone-scales; chiefly in threes in the Juniper; and in large numbers together in the Cypress, Taxodium, Kauri, \&c. The largest of the coniferous trees-Sequoia-produces the smallest seeds of the order.

Coniferce are represented in nearly all temperate regions of the world, the smallest known species being Dacrydium laxifolium, a 


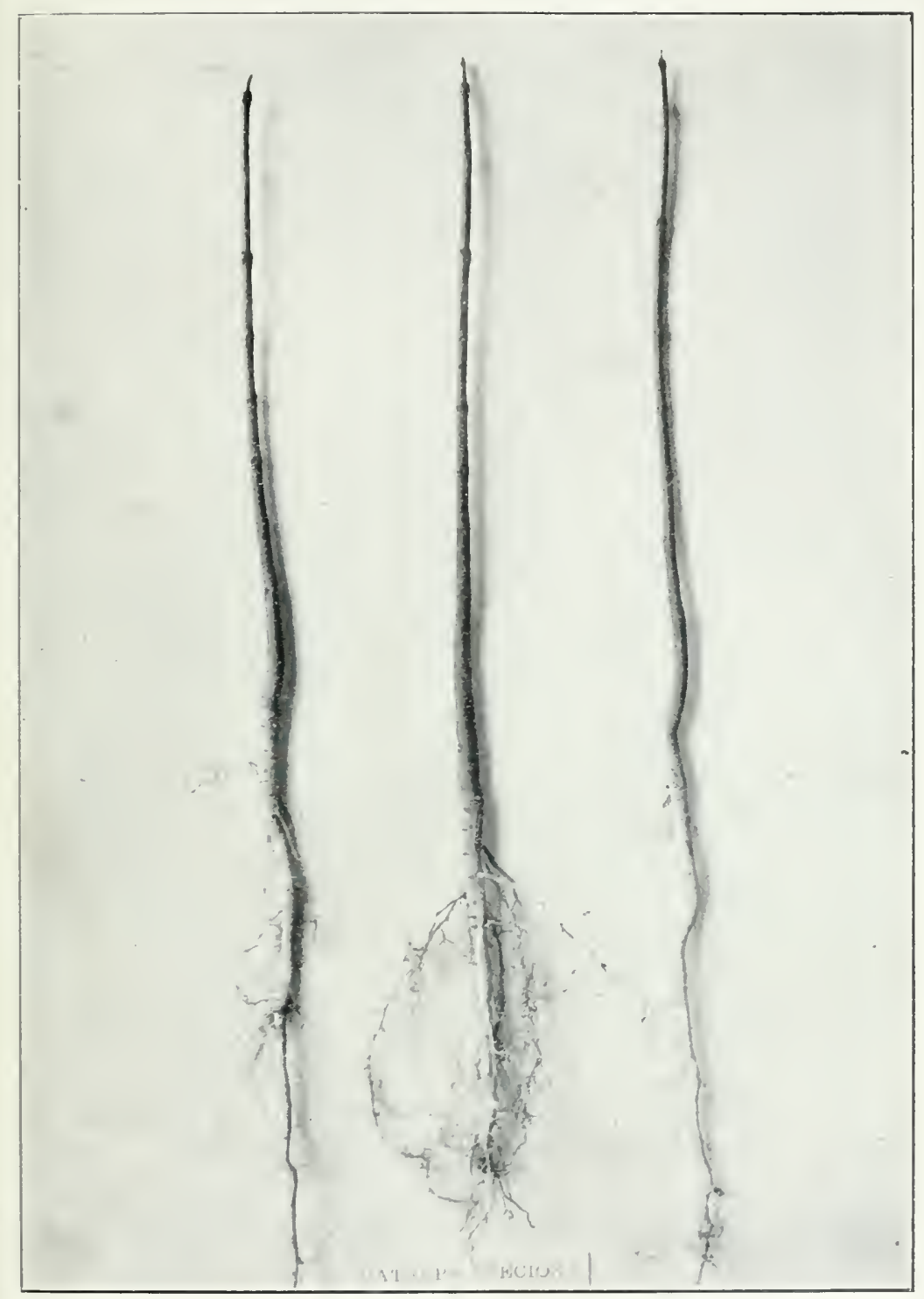

:linle 40.]

CATALPA SPLCIOSA SEEDLINGS IX WINTER,

[Face p. 80. 

plant common on moist mountain-ranges in New Zealand, and seldom attaining a height of over 12 in.; whilst the largest known coniferous tree is the Sequoia Weilingtonia, or "Big Tree" of California, specimens of which have been found to measure $450 \mathrm{ft}$. in height. The rate of growth varies considerably according to species and climate. The following table shows the extreme height-growth reached in one season, as recorded by the writer, in various portions of this colouy. The trees measured varied in age from six to eleven years :-

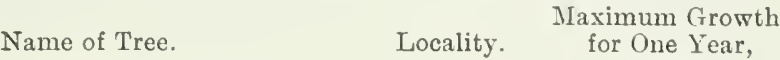

$$
\begin{aligned}
& \text { in Feet. }
\end{aligned}
$$

\begin{tabular}{|c|c|c|c|}
\hline aria e & $\ldots$ & and & \\
\hline Araucaria imbricata & $\ldots$ & NearWakatipu,Ota & ago \\
\hline Abies Nordmamiana & $\ldots$ & Dunedin ... & $\ldots$ \\
\hline Abies nobilis & & & \\
\hline Cupressus macrocarpa & $\ldots$ & Gisborne.. & \\
\hline Larix Europaa & & rua ... & \\
\hline Pinus strobus & & by, Otago & \\
\hline Pinus radiata (P. insignis & iis) & South Canterbury & .. \\
\hline Pinus Laricio ... & $\ldots$ & . & ... \\
\hline ponderosa & $\ldots$ & " & . \\
\hline Pinus Benthamiana & $\ldots$ & & \\
\hline Picea excelsa & $\ldots$ & South Otago & \\
\hline Pseudo-tsuga taxifolia & $\ldots$ & Taupo & \\
\hline Sequoia Wellingtonia & $\ldots$ & Hutt, Wellington & \\
\hline equoia sempervirens & $\cdots$ & South Canterbury & \\
\hline
\end{tabular}

The natural order of Coniferce is divided into five tribes or families, and each tribe comprises one or more genera, as follows :-

Tribe 1, Araucaria, comprises the genera Araucaria and Agathis (Kauri).

Tribe 2, Abietinea, comprises the genera Abies, Picea, Pinus, Tsuga, Cedrus, Larix, Pseudo-tsuga.

Tribe 3, Cupressince, comprises the genera Cupressus, Chanceyparis, Thuja, Biota, Libocedrus, Juniperus, and Callitris.

Tribe 4, Taxodinea, comprises the genera Sequoia, Cryptomeria, and Taxodium.

Tribe 5, Taxaa, comprises the genera Ginko, Torreya, Phyllocladus, Taxus, Podocarpus, Dacrydium, and Prumnopitys.

Araucaria. - Lofty evergreen trees, natives of the Southern Hemisphere; trunks straight and ereet; branches in whorls, lower ones bending downwards, those above ascending. Except in A. Bidwillii, the leaves are arranged spirally around the branches. The male cone droops, while the fertile cone stands erect. Contrary to the general opinion, both male and female flowers are sometimes produced on the same tree. Seven species are in cultivation. 
Agathis.-Immense evergreen trees with cylindrical trunks, whorled branches, and thick leathery leaves. Flowers are produced in October, and the cones usually ripen within eighteen months. Some ten species are known to botanists, the genus being restricted to New Zealand, Australia, and adjacent islands.

Abies (True or Silver Fir).-Evergreen pyramidal- or conicalshaped trees; branches produced in whorls; leaves arise singly from the branches, generally whitened on the under-side. The cones of all these Firs are cylindrical and erect, never pendulous, and they are usually ieveloped on the upper branches only, maturing and falling to pieces during the first year. Natives of Europe, Asia, and America. Thirty-three species are known.

Picea (True Spruce).-Evergreen, tall, erect trees, with slender branches; leaves (or needles) without stalks, growing singly, chiefly on the upper side of the branches. The cones are produced on the tips of the branches and are always pendant, ripening during the first year, but remaining intact. The Spruces are indigenous to Europe, Asia, and America. About twenty species are known.

Pınus (True Pine).-A genus comprising about seventy species, widely dispersed over the extra-tropical regions of the Northern Hemisphere. Pines are mostly tall trees with rounded tops, natives of Europe, Asia, and North America. The leaves are needleshaped, produced in bunches of two, three, or five. They vary in length from $\frac{1}{2} \mathrm{in}$. to $18 \mathrm{in}$., the latter only in $P$. longifolia. The leaves remain on the branches from two to seven years, depending greatly on the soil and situation. The cones ripen their seeds during the second year, and remain attached to the trees for several years.

The pines admit of a division into three sections, according to the number of leaves growing in a bunch or sheath. The species enumerated in the alphabetical list only are dealt with. In order to assist identification a few leading characteristics are also given.

\section{Pines with Two Leaves in a Bunch.}

P. Austriaca. - Leaves $2 \frac{1}{2}$ in. to $5 \mathrm{in}$. long, erect, stiff, and prickly-pointed; outer surface half round, inner surface nearly flat; glossy dark green. Cones conical, redàish brown, 2 in. to 3 in. long, rounded at the base; branches numerous, stout, and stiff.

P. Laricio.-Leaves $4 \mathrm{in}$. to $6 \mathrm{in}$. long, spreading, medium stout, mostly twisted; cones pale brown, $3 \mathrm{in}$. to $4 \mathrm{in}$. long; branches produced in regular whorls; growth erect and conical.

$P$. pinaster.-Leaves 6 in. to $8 \mathrm{in.} \mathrm{long,} \mathrm{dark} \mathrm{green,} \mathrm{rigid} \mathrm{and}$ stout; cones $4 \mathrm{in}$. to $6 \mathrm{in}$. long, growing in clusters, yellowishbrown, with short straight prickles; branches in regular whorls, turning upwards.

$P$. resinosa.-Leaves 5 in. to 6 in. long, in dense bunches on the points of the branches, straight and stiff; cones often clustered, 2 in. 


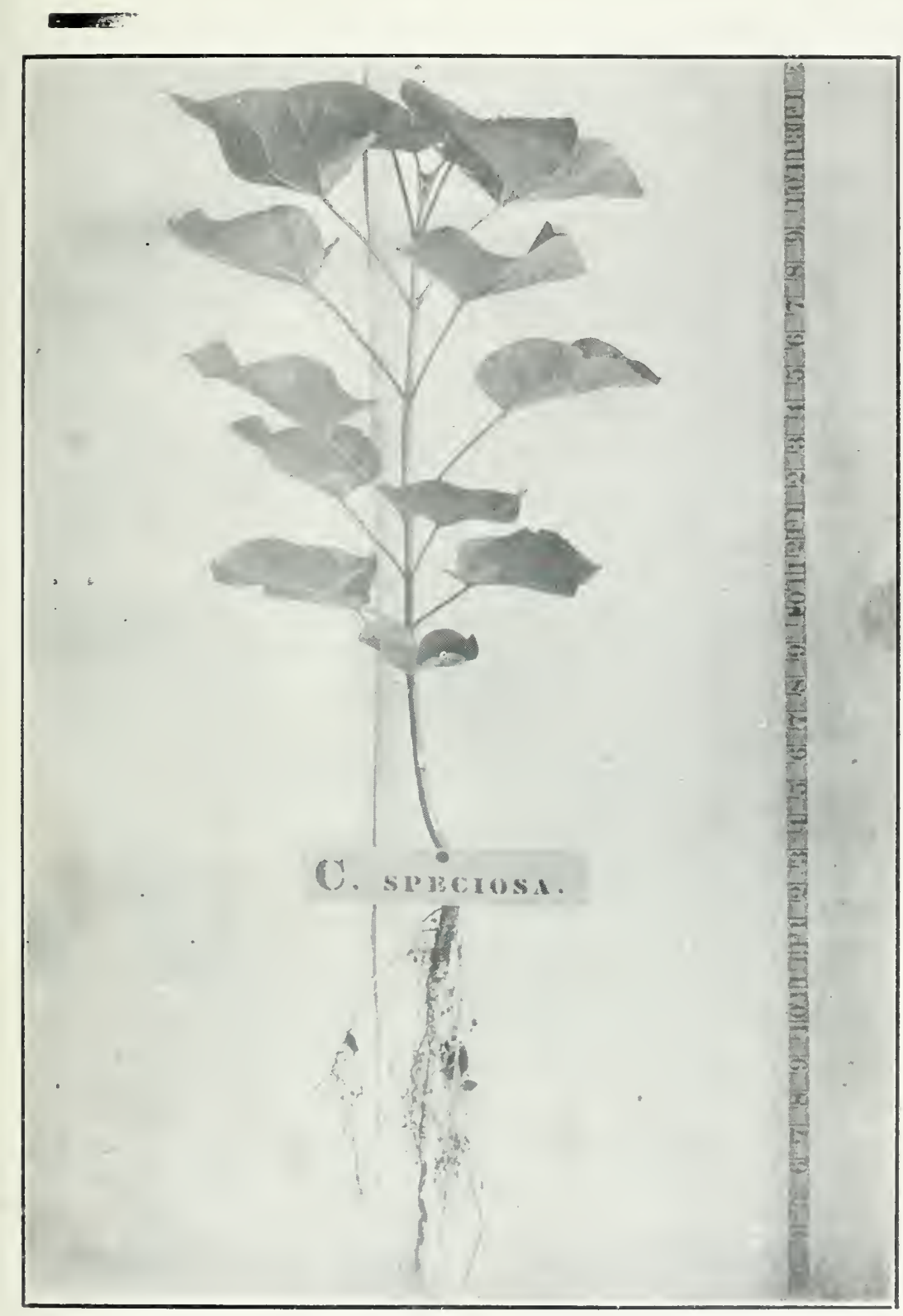

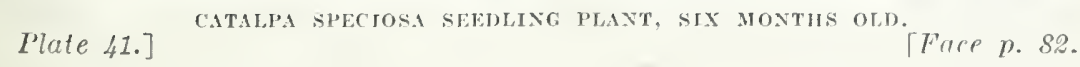



long, $1 \frac{1}{4} \mathrm{in}$. broad, egg-shaped, and round at the base: branches in distiuct whorls.

$P$. echinata.-Leaves $3 \mathrm{in}$. to $4 \mathrm{in}$. long, soft, slender, sharppointed; cones $1 \frac{1}{2} \mathrm{in}$. long, oval, remaining on the branches for many years after discharging the seeds; branches more or less in regular whorls.

$P$. contorta.-Leaves $1 \mathrm{in}$. to $2 \mathrm{in}$. long, dense, dark green ; cones almost spherical, $1 \frac{1}{2}$ in. long, remaining on the trees for many years ; branches numerous and much twisted.

$P$. halepensis.-Leaves 4 in. to 5 in. long, slender, light green, at the encis of the branches, leaves fall after two rears; branches slender and naked; cones pyramidal, smooth, $2 \frac{1}{2}$ in. to $3 \mathrm{in}$, long, yellowish-brown.

P. pinea.-Leaves about $6 \mathrm{in}$. long, deep green, stiff and straight; cones $4 \frac{1}{2} \mathrm{in}$. to $6 \mathrm{in}$. long and about $3 \mathrm{in}$. in diameter, recurved, blunt prickles, requiring three years to ripen, remaining on the branches, which are very much spread.

P. muricata.-Leaves 3 in. to $6 \mathrm{in}$. long, bright green, convex on one side, concave on the other; egg-shaped cones, mostly in clusters, covered with sharp points or prickles; cones remain unopened on the trees for many years; branches and foliage unusually dense.

\section{Pines with Three Leaves in a Bunch.}

$P$. ponderosa.-Leaves 6 in. to $8 \mathrm{in.} \mathrm{long,} \mathrm{dark} \mathrm{glaucous} \mathrm{green,}$ rigid, three-angled, remaining only on the extremity of the branches; cones 3 in. to 4 in. long, rich brown colour, conicalshaped, slightly prickled; branches regularly whorled, shining as if varnished. Many forms of this tree differ from the foregoing description.

P. ponderosa, var. Benthamiana.--Leaves much longer than the typical species, usually $9 \mathrm{in}$. to $10 \mathrm{in}$., dark apple-green, very stout and rather flat; cones 6 in. long, $2 \frac{1}{2} \mathrm{in}$. broad, usually in clusters of 3 to 5, slightly pendulous, green until mature, then leathery-brown; seeds nearly $\frac{1}{2}$ in. long: trees spire-shaped.

$P$. Jeffreyii.-Leaves $9 \mathrm{in}$. to $10 \mathrm{in}$. long, clustered at the ends of the branches, rigid and spreading; cones large, $8 \mathrm{in}$. to $9 \mathrm{in}$. long, purple until maturity, then leathery-brown, covered with hooked prickles; seeds pale, $\frac{1}{4}$ in. long; tree usually dome-shaped.

P. radiata (Pinus insignis).-Leaves $4 \mathrm{in.} \mathrm{to} 6 \mathrm{in.}$ long, àark green, thread-like, twisted; cones 4 in. to $5 \mathrm{in}$. long, uneven in outline; branches very spreading, frequently horizontal.

$P$. palustris.-Leaves 8 in. to 12 in. long, rounderi on the back, crowded into dense tufts on the tops of the branches; cones conical, $6 \mathrm{in}$. to $8 \mathrm{in}$. long, horizontal on the branches, covered with short hooked prickles. 
$P$. rigida.-Leaves $3 \mathrm{in}$. to $5 \mathrm{in}$. long, rigid, sharp-pointed, light green; cones in clusters of 4 or 5 , ovoid, 3 in. long, armed with sharp hooked prickles, remain on the trees many years.

P. Tada.-Leaves 5 in. to 8 in. long, slender but stiff, slightly twisted, pale-green colour; cones conical, 3 in. long, covered with stout, slightly hooked prickles; lower limbs spread horizontally, upper limbs more erect.

P. Canariensis.-Leaves 6 in. to 8 in., long, slender, and drooping, bright bluish green ; cones oblong, 6 in. long by 3 in. broad, hard and glossy ; branches in whorls.

P. Sabiniana.-Leaves slender, $10 \mathrm{in}$. to $12 \mathrm{in.} \mathrm{long,} \mathrm{glaucous} \mathrm{grey,}$ sharp-pointed, angular on inner side, rounded on outer side; cones large, rich brown; $8 \mathrm{in}$. to $10 \mathrm{in.} \mathrm{long,} 6 \mathrm{in}$. wide, always hanging on long stalks, covered with stout, hooked prickles.

P. Coulterii.-Leaves $10 \mathrm{in}$. to $14 \mathrm{in.} \mathrm{long,} \mathrm{dark} \mathrm{green,} \mathrm{stiff} \mathrm{and}$ stout; cones conical oblong, tapering to a point, $12 \mathrm{in}$. to $16 \mathrm{in}$. long by $6 \mathrm{in.} \mathrm{broad,} \mathrm{covered} \mathrm{with} \mathrm{incurved} \mathrm{hooks,} \mathrm{colour} \mathrm{yellowish}$ brown; branches in whorls, usually horizontal, tips elevated.

$P$. attemuata ( $P$. tuberculata).-Leaves 5 in. to 6 in. long, stiff, light green; cones mostly in clusters of 4 , produced on the main stem as well as the branches, seldom falling off, $5 \mathrm{in.} \mathrm{long,}$ conical-shaped.

\section{Punes with Five Leaves in a Bunch.}

P. Torreyuna.-Leaves the stoutest of all Pines, $8 \mathrm{in}$. to $10 \mathrm{in}$. long; cones 4 in. to 6 in. long, dull madder-purple, beehive-shaped, short blunt-pointed prickles; branches in whorls, rather distant.

$P$. strobus.-Leaves $3 \mathrm{in}$. to $5 \mathrm{in}$. long, slender, soft, light green; cones 6 in. to $8 \mathrm{in}$. long, eylindrical, tapering, and slightly curved, perfectly smooth.

P. Lambertiana.-Leaves clustered on the points of the branches, $3 \mathrm{in}$. to $5 \mathrm{in}$. long, three-angled, slightly twisted, bluish-glauccus green; cones 10 in. to 15 in. long, 3 in. to 4 in. diameter, cylindrical, tapering at the point, erect when young, pendulous at maturity; seeds oval, $\frac{3}{4}$ in. long, edible; branches in regular whorls, pendulous at the extremities.

$P$. flexilis.-Leaves 2 in. to $2 \frac{1}{2}$ in. long, three-angled, rigid; cones elongated, egg-formed, 4 in. to 6 in. long; branches very flexible; conical, symmetrical growth.

P. monticola. - Leaves about 3 in. long, three-angled, bluntpointed; cones 5 in. to $7 \mathrm{in}$. long, generally in clusters, $1 \frac{3}{4}$ in. wide, tapering to a blunt point; branches stout and short; pyramidal habit.

P. albicaulis.-Leaves $1 \frac{1}{2} \mathrm{in}$. long, light glaucous green; stiff, white-barked, flexible branches; cones egg form and size, purplebrown; seeds very small; very similar in growth to $P$. flexilis.

$P$. cembra.-Leaves $3 \mathrm{in}$. to $5 \mathrm{in}$. long, rigid, three-angled, with rough edges; cones erect, $2 \mathrm{in}$. to $3 \mathrm{in}$. long, oval, smooth; seeds 


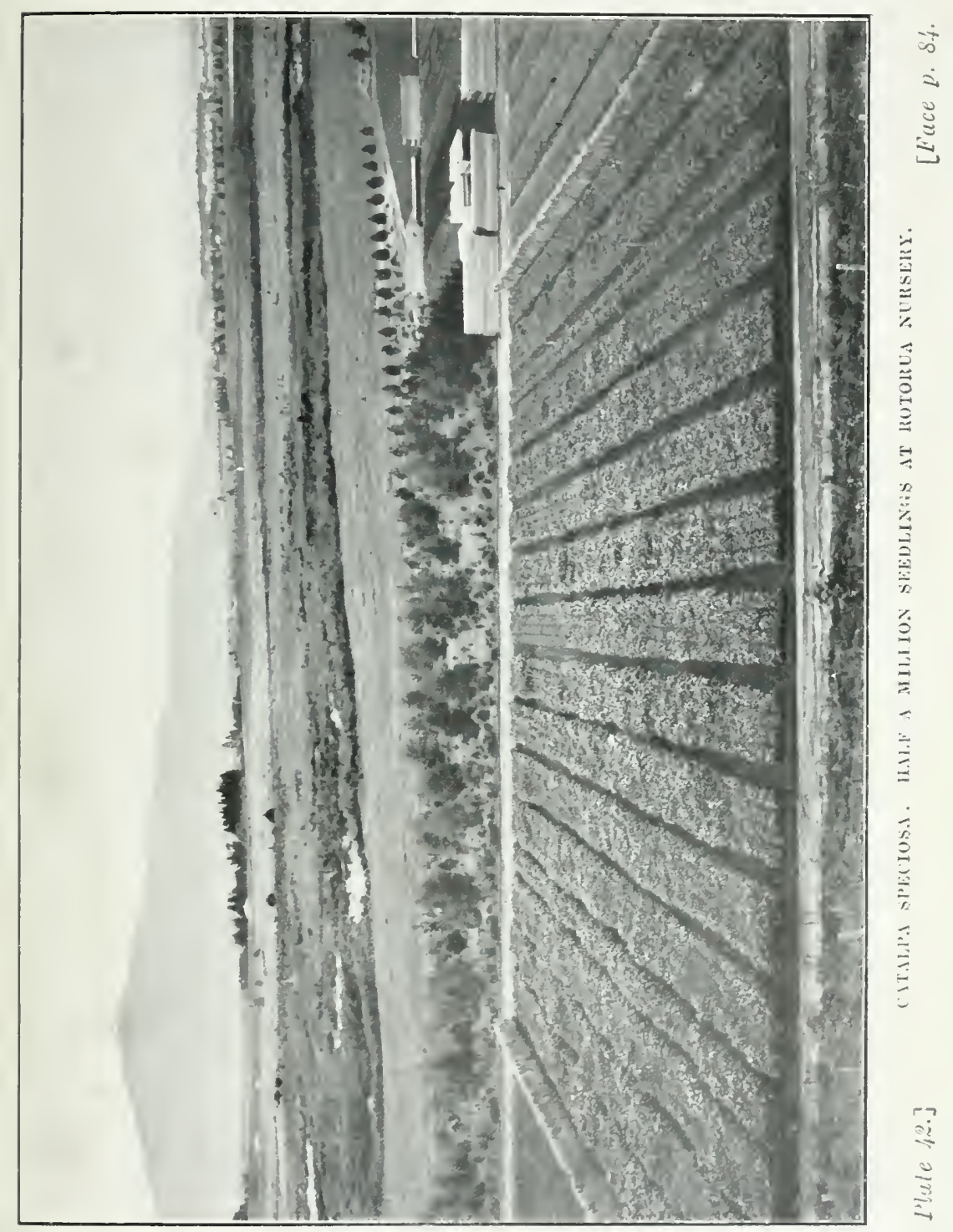



$\frac{1}{2}$ in. long, edible; tree of elongated pyramidal outline, with short crooked branches, deep-green foliage.

P. excelsa.-Leaves $6 \mathrm{in}$. to $8 \mathrm{in}$. long, slender and drooping, three-angled, glaucous-bluish green; cones 6 in. to $8 \mathrm{in}$. long, pendant when mature, pointed; branches in regular whorls.

Tsuga (Hemlock Spruce).-Tsuga (pronounced "soonga," with the accent on the last syllable) is the Japanese name of a tree, meaning "yew-leaved" or evergreen. This genus resembles the genus Picea (or True Spruce) in many respects, differing principally in haring flattened sprays of foliage, the leaves mostly in two rows instead of being scattered, and each leaf is needle-shaped and has a short stalk. Six species are known-two in central Asia; one, the original "Tsuga," in Japan; one in India ; and three in America.

Psendo-tsuga (False Spruce). - This unpronounceable name was coined by the French botanist Carrière to replace the well-known one of Abies Douglasii, which is now called Pseudo-tsuga taxifolia. This is a small but very important genus of two species only, both natives of America. The distinguishing features of this genus are too highly technical and hair-splitting for others than botanists.

Cedrus (True Cedar). - This small but historical genus comprises three species-one found on Mount Lebanon, another on the Himalaya Mountains, and the third on the Atlas Mountains of northern Africa. The leaves are evergreen and somewhat foursided, stiff, sharp-pointed, and grow in small bunches like those of the Larch; the cones are erect, and blunt at both ends; they attain maturity in from two to three years. The leading stem of Cedrus Deodara is never erect as in most trees, but always pendulous, the drooping point making a complete revolution in three years.

Larix (Larch).-The Larches possess characteristics distinct from the firs (their nearest allies), especially in the leaves, which are clustered in bundles, and are deciduous; they are also soft and pliable, while those of firs are stiff and evergreen. The flowers of larch and fir are almost identical, and the cones differ but little except in shape. Eight species are known-one in the European Alps, one in Siberia, one in India, two in Japan, and three in America.

Cupressinaa (True Cypress). - The Cypresses comprise about fourteen specres, widely distributed-three belong to China and India, three to the Mediterranean, and eight to America. The general characteristics which distinguish this genus of trees and shrubs are their numerous, scattered, flattened branches, which give them a fern-like form. The foliage is of two kinds-first needle-shaped, then later scale-like, closely surrounding the branchlets. The cones are usually small, and are spherical, seldon over $1 \mathrm{in}$. in diameter, and require two years to mature. A number of species have been removed from this genus and placed under the next. 
Chamceyparis (Ground Cypress).-This genus of three species, indigenous to America, includes the numerous varieties of the two species of Japanese Retinospora-R. obtusa and $R$. pisifera, both the latter being retained by Kew Gardens as Cupressus. The Ground Cypresses were removed from Cupressus chiefly on the score of having their branchlets in two rows, the cones maturing in one year, and the seeds being more or less "winged." The bestknown species is Chamecyparis Lawsoniana, commonly called Cupressus Lawsoniana, of which no less than sixty-eight varieties are. cultivated by American nurserymen.

Thuja (including Biota) (American Cedar, or True Arbor-vitæ).— Evergreen shrubs or trees with flattened branches, and minute scale-like leaves arranged in opposite pairs; the cones are oval, and are composed of eight or ten scales, of which only two are fertile, with double-winged seeds at the base. Two species are natives of North America, one of Japan, and one of China, the latter being commonly called Biota orientalis (Chinese arbor-vitæ).

Libocedrus (Incense Cedar).-Libocedri are tall trees of pyramidal or columnar habit, elothed with scale-like leaves arranged in opposite pairs and prolonged down the stem. The cones are erect or pendant, usually less than $1 \mathrm{in}$. long, and are produced on the tops of the upper branchlets. The cone is composed of several scales, at the base of which two to four unequal winged seeds are developed. Two Librocedri belong to New Zealand, two to Chili, and one to northern America.

Juniperus (Juniper).--Medium-sized trees, bushy or prostrate shrubs, belonging to both hemispheres; all are evergreen and resinous; leaves are usually of two kinds--either small, prickly, and needle-shaped in bunches of threes, or scale-like, overlapped in four rows; both kinds are frequently seen on the same plant. Unlike the order to which the genus belongs. the fruit or berry is succulent, and covered with a glossy skin. There are usually three hard, bony, three-cornered seeds produced in each berry. Some thircyfour species are in cultivation.

Callitris (Cypress Pine).-A small genus of African and Australian trees and shrubs, evergreen and highly resinous; leaves very minute and scale-like, closely covering long slender-jointed branches. The male and female flowers are produced on the same tree. The cones are globular, and composed of several unequal-sized woody scales, with one or two seeds at the base of each.

Sequoia (Mammoth Tree).-Two species only are known-the Big Tree and the Redwood. The leaves of the latter are Yew-like, in two rows, while those of the Big Tree are small and scaly, arranged round the branches in regular spirals. The cones of both species are exceedingly small for such colossal trees, while the seeds are most minute, although the wings on either side of them make them appear larger than they really are. Cones of both species are produced singly on the ends of the branches, those of the Big Tree 


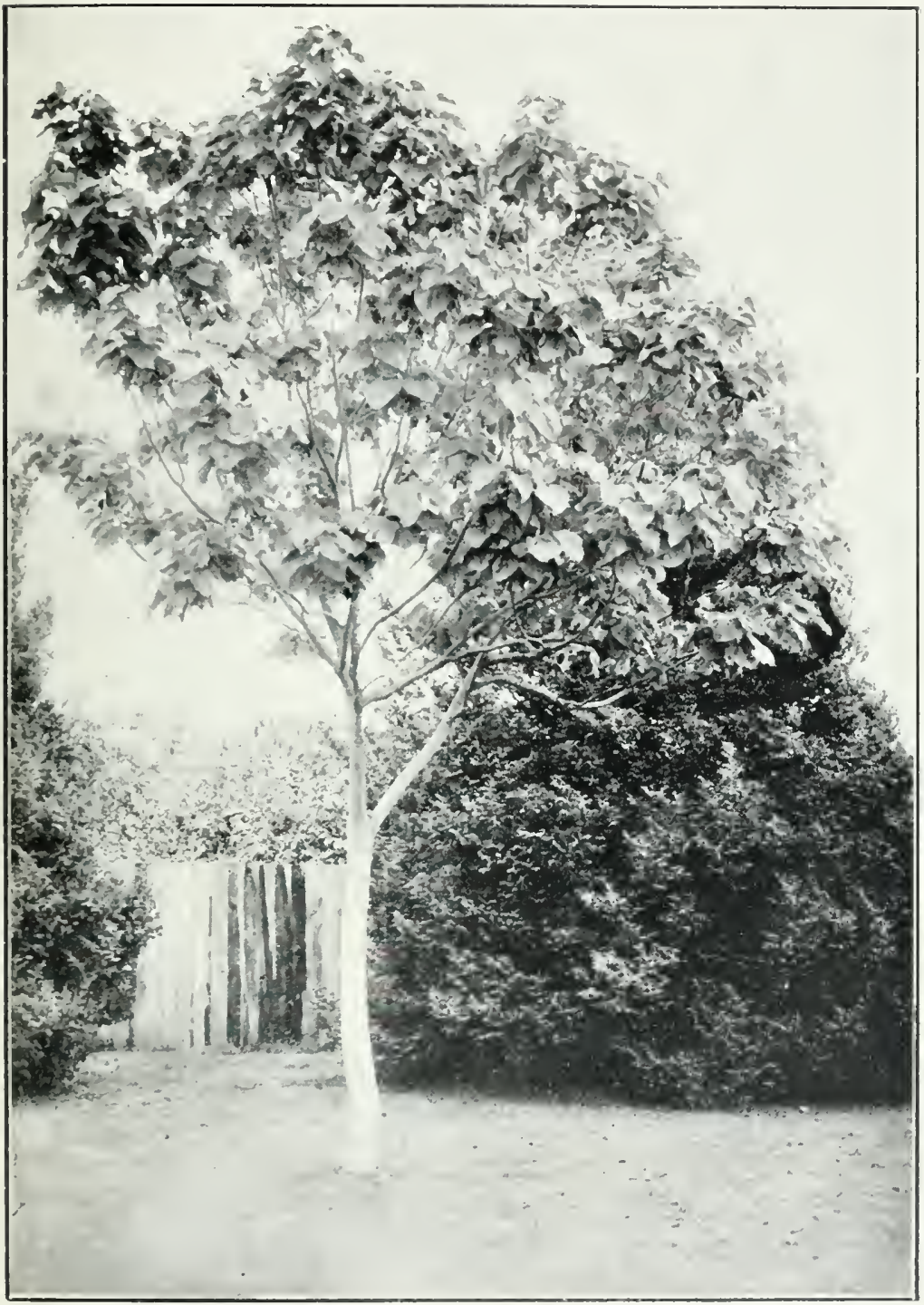

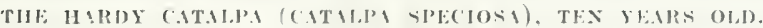

l'late 43.]

[Five p. sli. 

being about $2 \mathrm{in}$. long and $1 \mathrm{in}$. diameter, blunt-ended, and those of the Redwood about 1 in. long aud egg-shaped.

Cryptomeria (Japan Cedar).-Only one species is known-C. japonica-although several distinct varieties are cultivated, the principal one being C.jap. elegans, very much unlike the typical species. The leaves are set closely to the stem without stalks, and are sharp-pointed and sickle-shaped; the cones are globular, $\frac{1}{2}$ in. in diameter, and produced at the tops of the branches; they ripen during the year of tlowering.

Taxodium (Deciduous or Bald Cypress).-Two species only are known-one native to the southern United States, and the other to Mexico. The leaflets are light green, about $\frac{1}{4} \mathrm{in}$. long, set like the teeth of a comb, in two rows, along the branchlets; the cones are about $1 \mathrm{in}$. in diameter, globular, and produced at the base of the shoots: they ripen during the second year. The foliage changes to a ciull red before falling in the autumn.

Ginglio (Maidenhair Tree). - This genus contains only one species, native to China and Japan. Unlike other coniferous trees, the Gingko is non-resinous. The leaves are triangular, fan-shaped, and resemble tiose of a maidenhair fern; they are the same colour and texture on both sides. The fruit or nut is globular, about the size of a walnut, and contains a kernel the size of a hazel-nut.

Torreya (False Nutmeg). - This genus comprises four evergreen species, found in Japan, China, Florida, and California. They are small trees, much resembling the common Yew, the leaves being arranged in singie rows. The fruit is a fleshy fibrous envelope, enclosing a single seed. Now known by American botanists as Tumion.

Phyllocladns (Celery Pine).-Three species are natives of New Zealand, one of Tasmania, and one of Borneo. This remarkable genus of evergreen trees produces true leaves only in the young state. "Cladodes," which are really Hattened branchlets, take the place of the mature leaves after the tree has passed the seedling stage. The fruit or cone is connected by a short stalk, and is a membranous cup-shaped envelope containing nuts.

Taxus (Yew).-The Taxads are resinous like other Coniferce, and with one exception are of exceedingly slow growth. Their leaves are narrow, flattened, and entire; the fruit is always oneseeded, enclosed in a fleshy covering. Four species only are known - two in America, one in Europe, and one in Japan. Many varieties are in cultivation, the best known being the Irish Yew-an accidental freak discovered on the mountains of Fermanagh. Seedlings raised from this variety always revert to the common type.

Dacrydium (Weeping Pine). - Dacrydium is represented by seven species in New Zealand, one in Tasmania, and the remainder in the Pacific islands, Borneo, and Malay Archipelago. The leaves are usually of two forms - first linear, arranged one above the other in two rows, then short and stumpy, closely 
adhering to the branchlets, which resemble whipcord. The fruit or nut is produced singly on the tips of the branches, and is usually oval, not unlike a miniature acorn. The largest-growing species is the New Zealand Red-pine (D. cupressinum), usually under $100 \mathrm{ft}$. ; and the smallest $D$. laxifolium, seldom more than 10 in. or $12 \mathrm{in}$.

Podocarpus (Stalk-berried Pine).-About sixty species are known to science, six of which are found in New Zealand. They are usually medium-sized trees with very variable, linear, leathery leaves crowded together or much scattered along the branchlets. The fruit is small and plum-like in structure, enclosing a single kernel or seed ripening during the first year. The well-known Matai or Black-pine has recently been removed from this genus and placed under-

Prumnopitys (Plum-fruited Pine). - Three species only are known-two native to Chili, and one to New Zealand. The leaves resemble the Yew in general appearance, and the fruit is small, fleshy, and cherry-like, containing a single hard nut.

\section{CHAPTER XVIII.}

\section{THE CORK-OAK.}

(x)

ANY parts of this colony are adapted for the successful growth of the Cork-oak, as has been proved by the excellent specimens of these trees growing in widely scattered districts, and by the first-class quality of the cork produced. By way of illustrating its adaptability to the varying soils and climates of New Zealand, healthy well-grown trees may be seen in the grounds of several residents in Dunedin; in the Public Domain, Christchurch; in the Hutt Valley, Wellington; and in the town of Auckland. Probably the oldest tree in the colony is to be seen in the grounds of J. McK. Geddes, Esq., Symonds Street, Auckland. It was planted in 1855 by the late Dr. Sinclair, who procured a small plant from Kew Gardens, London. This tree has produced acorns for mauy years, and these have been liberally distributed by the owner. The late Mr. Justice Gillies stripped the first layer of corkbark from this tree in 1877 . Four years later the bark was again stripped and cut into corks, which were pronounced by experts to equal those of imported second-stripping. This tree has been "stripped " four or five times since 1881, and each successive layer has improved in quality as the age of the tree increased, showing conclusively that cork can be produced successfully and of equal commercial value to the imported article.

Two species of Cork-oak are known-Quercus occidentalis, of Gascony, and Q. suber, the former being much hardier than the 


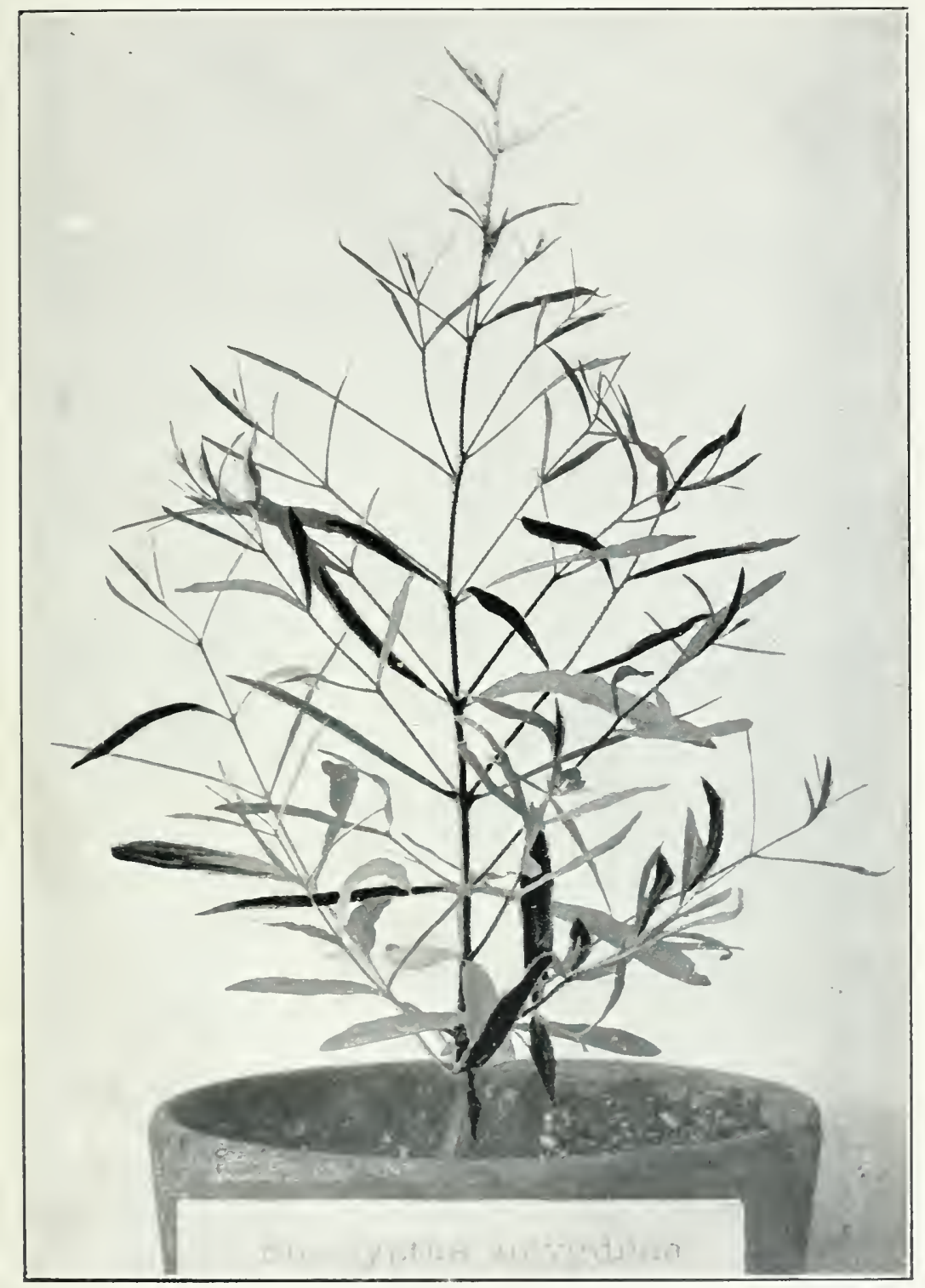

ECCALYPTI'S AMYGDALIXA SEEDIIX, SIX MONTHS OLD. Plute 44.]

[Fuce p. $8 S$. 

more common species. Both are evergreen, with oval-oblong and frequently toothea leaves, about $2 \mathrm{in.}$ long and $1 \mathrm{in}$. broad. Q. suber is native to the basin of the Mediterranean, both on the European and African shores. In Algeria it is found at an elevation of 4,000 ft., while in France its cultivation is limited to about 2,000 ft. The present existing cork forests cover an area of three and a half million acres, chiefly in Portugal, Spain, and Algeria; while Italy, France, and Tunis contribute nearly a hundred thousand acres each.

The precise requirements of the Cork-oaks in regard to soil, situation, exposure, and climate are not yet known in this colony, although from the present limited experience it may be said that free open soils, sheltered situations, northern exposures, mild climates, and a fair amount of rainfall show the best results. Limestone soils or dry shingly land are both unsuitable for its cultivation.

Although locally grown acorns are available in small quantities, these are generally bespoken by nurserymen and amateurs, so that intending cultivators will require to import their supplies from France or Italy, where the average cost is about $£ 2$ per hundredweight. A considerable percentage of loss during transit may be expected, owing to the acolns soon losing their germinative powers unless sown at once. The packing-material, to ensure comparatively successful results on arrival, is powdered charcoal, which should be mixed in about equal quantities with the acorns and packed in zinc-lined cases. The acorns ripen in Europe during October and November; supplies should therefore reach the colony about Christmas, when they should be sown at once in the place where they are intended to remain. The necessity for direct sowing in regard to the cork-acorn is due to its extensive root-system even during the first or second years. Plate 37 shows acorns germinating with the roots fully $12 \mathrm{in}$. long, while the upward growth is barely $1 \frac{1}{2}$ in. Frequently acorns are sown in pots or boxes with the intention of transferring them to their permanent quarters when the plants are ore year old. This is not a commendable practice, as may be seen from Plate 38, where the strong tap-root, on reaching the bottom of the box in which it was sown, turned at right angles until it found a joint in the boards which allowed it to continue its natural downward course. By sowing in pots the results are even worse, as the tap-root is either through the hole in the bottom of the pot or coilerl around its sides like a corkscrew, long before there is any appearance of growth above ground. The difficulty in successfully transplanting the Cork-oak without injuring the extraordinarily long tap-roots is therefore evident, and planting in situ may be considered the only saie method of propagation.

The manner of sowing differs in no way from that recommended under " Raising Plantations by Direct Sowing," and need not therefore be repeated here. If the trees are intended for the production of acorns the distance from plant to plant should not be 
less than $20 \mathrm{ft}$.. in order to allow full development of branches and. foliage. To produce cork in long clean layers it will be necessary to plant the seeds at $8 \mathrm{ft}$. apart, and also introduce some other species of tree between the Cork-oaks, thus making the whole of the trees stand at $4 \mathrm{ft}$. apart.

The class of tree selected to act as a nurse (or branch-suppressor) should be one whose growth is rather faster than that of the Oak, in order to draw up the leading stem of the latter to its ultimate height as free of branches as possible. Any of the easily raised Pines-such as $P$. muricata, $P$. Canariensis, $P$. halepensis, and $P$. Austriaca-are suitable for this purpose, and when their mission has been fulfilled they can be removed, leaving the Cork-oaks in full possession of the land. A belt of three or four rows of any of the above-named Pines should be planted on the outskirts of the plantation for shelter purposes.

The cork of commerce is not the natural product of the tree, but an abnormal development of the bark under special treatment. The natural or virgin cork is useless for manufacturing purposes, owing to its being deeply furrowed, irregular in growth, and woody. The tirst stripping takes place when the trees are from 12 in. to $18 \mathrm{in.}$ in diameter, and the removal of the first layer prepares the way for the growth of the commercial article. The cambium-layer develops new cork by annually increasing layers, as in the barks of other trees. Every fifth or sixth year (or when the new bark has attained $1 \mathrm{in}$. in thickness) this process of bark-peeling is repeated -usually in midsummer-and only a few feet of the trunk is stripped at one time, so as not to expose more than one zone of the mother-layer in the same year, otherwise there is considerable risk of the death of the trees by excessive decortication.

Whether the cork industry will become an established one in this colony can only be proved by time. The Government have already commenced making plantations near Whangarei, so far with satisfactory results, and arrangements have been made to plant some ten thousand acorns each season.

\section{CHAP'TER XIX.}

\section{CATALPA SPECIOSA (HARDY CATALPA).}

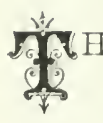

IIS tree has aroused considerable interest throughout the colony during the last few years, owing to its reputation for providing almost indestructible timber within a comparatively shol't time. Although introduced into Nerv Zealand some twenty years ago, there are very few specimens to be found in gardens, and, as our experience in its cultivation is limited to only twelve years, nothing definite can be said as to its timber-producing 


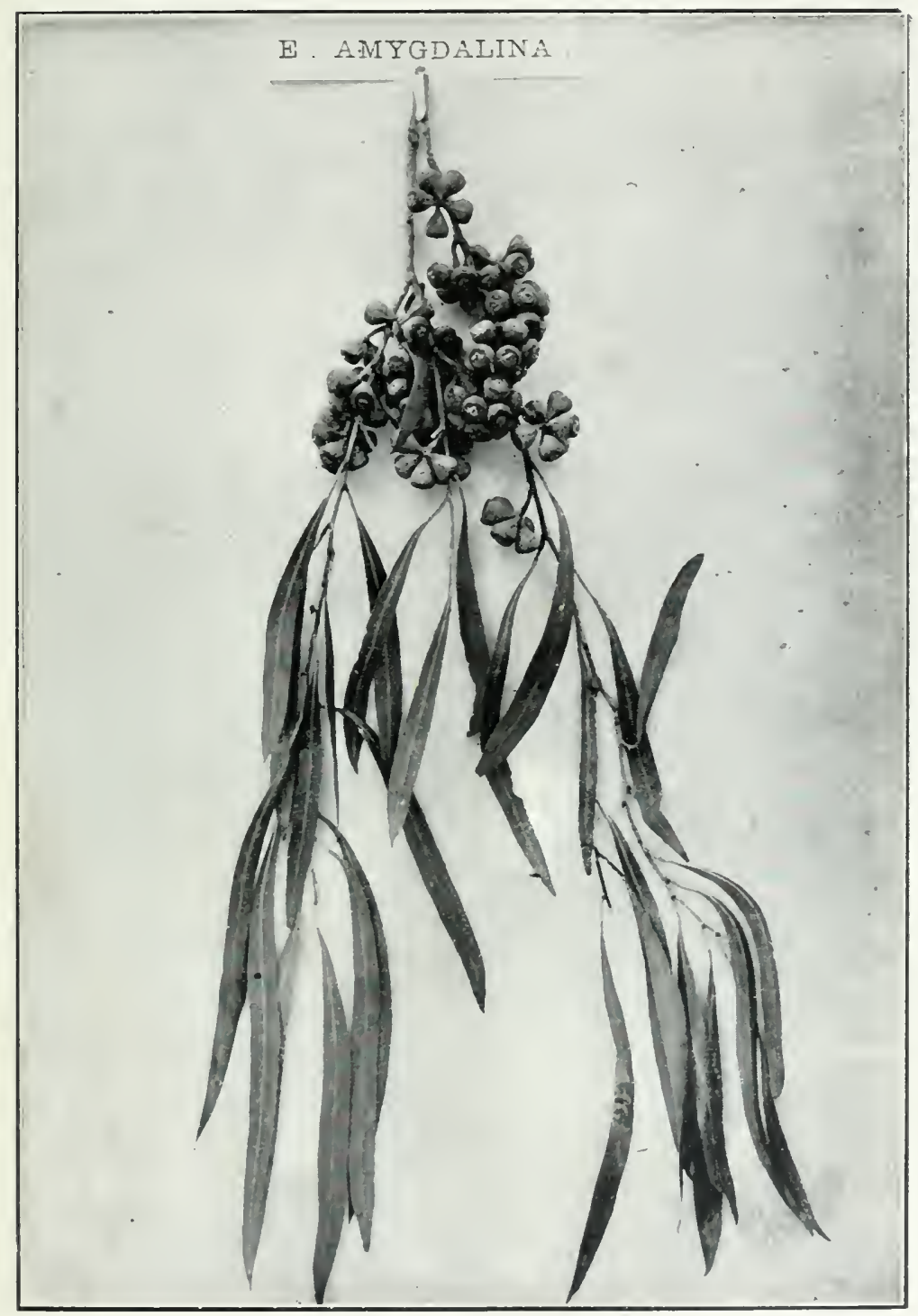

EUCALYPT'S AIYGDALINA: ADILT FOI.IGE ANI) RIPE ('APSITES, ONE-HALF Illule 45.5

NATURAL SIZE.

Fice p. 90. 

qualities in this colony. So far it has proved to be a tree that is easily raised, transplants well, and grows quickly, while it prefers somewhat moist, rich, open soil and a moderate climate. It attains a height of from $60 \mathrm{ft}$. to $80 \mathrm{ft}$., with a diameter of $2 \mathrm{ft}$., in its natural habitat. Plate 43 shows a ten-year-old tree of about $30 \mathrm{ft}$. in height, grown as a specimen. Plates 40 andi 41 represent seedling plants six months old.

The Catalpa belongs to the natural oräer Bignoneacea, which includes the well-known climbers Eccremocarpus scaber and T'coma radicans. Two species are natives of northern America-Catalpa cutalpa (syn. C. bignonioides-the Indian Bean) and Catalpa speciosa (Hardy Catalpa); there is also one species indigenous to China, and one to Japan.

There is a close resemblance between the two American species; indeed, in the seedling stage it is difficult to observe any distinctive feature; while in southern Missouri, where both species are found, natural hybrids between these are met with-a circumstance which has not only caused considerable confusion in determining precisely where to place them botanically, but has also led to the seed of the worthless-timber producer being collected and distributed throughout the world as that of the more valuable hardy timber-tree under notice. It is therefore of vital importance that seeds of the true C. speciosa be obtained. Unfortunately, the seeds of all species are very similar, and it is almost impossible to distinguish between them. C. speciosa, however, has a flattened bunch of flaments at each end, while the filaments of the other species are drawn to an irregular poirt.

The flowers of the true Catalpa speciosa are trumpet-shaped and white, faintly spotted and flaked with purple, about $1 \frac{1}{2} \mathrm{in}$. long and the same in dianeter. The leaves are large, heart-shaped, and have only one apex, whereas the worthless species has small flowers very much spotted with yellow and purple, while the leaves are invariably three-pointed. All the species have cigar-shaped drooping seed-pods; those of C. speciosa are from $12 \mathrm{in}$. to $18 \mathrm{in.}$ long, or nearly twice the length of the other kinds, and $\frac{3}{4}$ in. in diameter, one or two only growing together.

C. bignonioides produces four to six seed-pods in each cluster, each being from $6 \mathrm{in}$. to $8 \mathrm{in}$. in length and little more than $\frac{1}{2} \mathrm{in}$. in ailameter.

There are no difficulties to contend with in raising the hardy Catalpa from seed, provided it is sown thinly and covered sparingly, just sufficient to screen the seeds from view. The necessity for thin sowing is owing to the vigour of the plants and the large leaves they produce, even during the first year. September in the north and October in the south will be found the best time for sowing. No shading is required, provider the seed-beds are fairly well sheltered; but if these are exposed some slight protection will be necessary to prevent the soil as well as the light-winged seeds from blowing away. The results of several trials show that $1 \mathrm{lb}$. of seed 
produces approximately four thousand plants. As the plants make from 12 in. to 18 in. of growth during the first year, it will not be necessary to transplant them into nursery-rows, as they can go direct to the plantation.

There has been mucl controversy in America regarding the distance at which Catalpa should be planted for its most favourable development as a timber-tree. Mr. John P. Brown, editor of "Arboriculture," says, "Thirty years' experience has proven that the roots of each Catalpa speciosa three years of age demands 16 square feet surface-space, at eight years 64 square feet, at ten years 100 square feet, and at sixteen years 250 square feet." $\mathrm{He}$ therefore recommends planting at $8 \mathrm{ft}$. by $8 \mathrm{ft} .-680$ per acre. The Bureau of Forestry, United States Department of Agriculture, in their recent Bulletin "The Hardy Catalpa," recommend $4 \mathrm{ft}$. by $4 \mathrm{ft}$. as the best distance to plant for the production of timber. In Rotorua district the Forest Department have adopted a medium distance-viz., $6 \mathrm{ft}$. by $6 \mathrm{ft}$.- for planting this tree, until a longer experience of its cultivation is gained.

In regard to hardiness, it is found that extreme frosts kill back the point of the leading shoot, which necessarily causes the development of side branches, and one of these must in such a case be trained to take the lead. As this only happens when the trees are young, it will be found a good plan to allow the trees to grow without pruning for, say, three or four years, and then cut them off close to the ground in early spring. Several strong shoots will be thrown up later, and the strongest one only should be left. This shoot will make a vigorous growth of from $6 \mathrm{ft}$. to $12 \mathrm{ft}$. in a single season if the soil and situation are alike suitable. Grown in the open it forms a spreading round topped tree, as shown in Plate No. 43 ; but when the side branches are checked by dense crowding the trunk grows fairly straight and with very little taper.

A peculiar feature of the Catalpa is the persistency with which the branches remain on the trunk after they have been killed by crowding. These are easily removed by giving them a sharp blow close to the stem with a stout stick. Unless this is done the new wood will form around the dead branches as long as these remain attached to the tree, and when the timber is cut there will be a blemish, in the shape of either a dead knot or a hole. Side branches on a Catalpa tree should never be allowed to attain more than $\frac{1}{2} \mathrm{in}$. in diameter if clean, sound, knotless timber is desired. When the branches become stout and commence to make heartwood, knots in the trunk will be the result. Should it be found that the trees have been planted too wide for early branchsuppression, stopping the laterals will tend to reduce their undue development.

According to the Bulletin previously mentioned, the Catalpa will produce solid-hearted timber even at the early age of ten years, and timber that is durable in contact with the ground, regardless of age or rapidity of growth, provided it is cut after the fall of the leaf and 


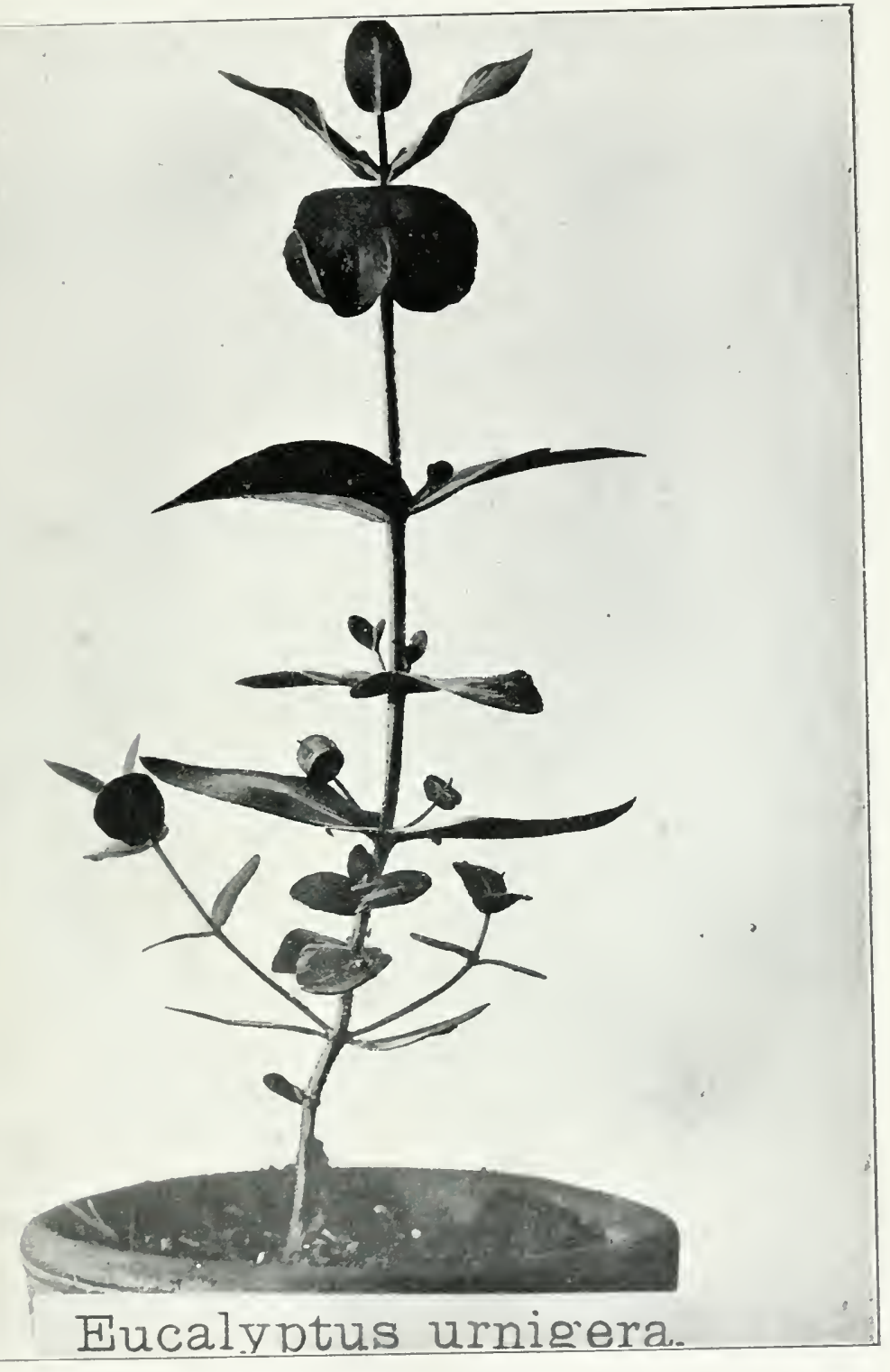

Ilrite 4fo.]

[Fuce p. 92. 

allowed to dry thoroughly before using. Instances are recorded of fence-posts still sound after twenty or thirty vears' service, and of railway-sleepers lasting eighteen years without showing any signs of decay.

With our present limited experience it is safe to say that the Catalpa can be grown successfully in most parts of New Zealand where the soil is moderately fertile, free, and open, the situation sheltered, the rainfall not less than $30 \mathrm{in}$. per annum, and where the thermometer does not fall below $20^{\circ}$ Fahr.

\section{CHAPTER XX.}

\section{EUCALYPTI.}

fETTLERS in most parts of the South Island have cause to (3) remember the extreme winter of 1903 , when the thermometer fell to $14^{\circ}$ below zero in several portions of central Otago. Previous hard winters were experienced throughout Otago and Canterbury in 1886 and 1899, doing an immense amount of damage to plantations, but last winter was by far the most severe yet experienced in the colony. Trees over forty years of age that had not been previously affected were killed to the ground, while more hardy species suffered severely, especially when growing on lowlying flats or valleys, where frosts are more keenly felt.

Both in Canterbury and Otago the greatest losses occurred amongst Eucalypti and Acacias, although the Monterey Pine and Cypress were both killed by thousands.

Extreme droughts were also responsible for many losses throughout the inland portions of Canterbury during the years 1886,1897 , and 1899 .

As the species of Eucalypti that have been found to withstand low temperatures are now tolerably well known, a brief descriptive outline, together with the accompanying illustrations, may be of assistance in determining species of recognised value for future planting. It should be noted that it is impossible to distinguish between many of the species unless specimens bearing flowers and ripe capsules in conjunction with the mature leaves are carefully examined.

Of the 130 species of Eucalyptus now known in Australia and Tasmania," it is only intended to deal with those that are native to the latter country, as being more suitable for extended cultivation in this colony, leaving the Australian species proper for subsequent consideration.

The Forest Department have some forty species of Australian

\footnotetext{
* Some species are natives of both Australia and Tasmania.
} 
Eucalypti under cultivation at the various nurseries and plantations throughout the colony, with the object of ascertaining the most useful kinds for varying soils and climates. Until these have been thoroughly tested for severai years no reliable information can be given as to their adaptability for general planting.

Special attention is directed to the system of "mossing" seedling plants of Eucalypti, Acacia, and other trees which are impatient of transplantation. By this means losses due to transplanting trees from the, seed-bed to the plantation are reduced to from 3 to 5 per cent., whereas in planting Eucalypti under the usual bare-root system fully 20 per cent. must be allowed for failures. During the present season over one million Eucalypti are being dealt with under this system at Rotorua Nursery, where the work is performed by Native women for 5s. per thousand. Any intelligent lad can after a few hours' practice "moss" as many as 1,000 per day. "Mossing" is usually done during the autumn or early spring. The young trees are then set in the ground closely together, as shown in Plate 21. After a few weeks it will be found that the roots have penetrated through the moss in all directions, and the plants are now ready for permanent planting.

The method of "mossing" is extremely simple: A small handful of moss is taken in the left hand and well spread out. About an ounce of fine soil is then laid on the moss, and on top of this the roots of the plant. The hand is then closed, which brings the outer edges of the moss together, forming an oval-shaped mass, which is bound obliquely, and tied firmly with a narrow strip of flax. When the roots of a plant are too long and bare for convenient "mossing," the points may be trimmed off with a sharp knife or sheep-shears in order to obviate any risk of bending them into unnatural shapes. Only one kind of moss, known as "Sphagnum," is suitable for the purpose, as it possesses the peculiar properties of always remaining moist without heating or otherwise deteriorating, even if closely compressed and kept from the air. Sphagnum is found throughout the colony in large quantities, either in swamps or near watercourses. One well-filled sack will hold sufficient material to moss about two thousand trees.

In loose or cultivated land the spots intended for planting should be marked out at the proper distance apart, and the "mossed" plants put in with a garden-trowel, completing the operation with a firm tramping around each plant. Where the land is of a hard nature, each "spot" should be well loosened up by a pick driven full depth into the ground half a dozen times. In rocky ground spots can be more conveniently prepared with a light crowbar. (See Plates Nos. $18,19,20,22,23$, and 27.

Twenty-two years ago the late $\mathrm{M}$ r. J. F, Armstrong, Superintendent of the Christchurch Domain, published the following list of Eucalypti which he had proved to be the hardiest: Eucalyptus amygdalina, E. coriacea, E. coccifera, E. urnigera, and E. obliqua. To these may now be added $E$. viminalis, $E$. Gunnii, E. Mucllerii E. hamastoma, E. Sieberiana, and E. Stuartiana. 


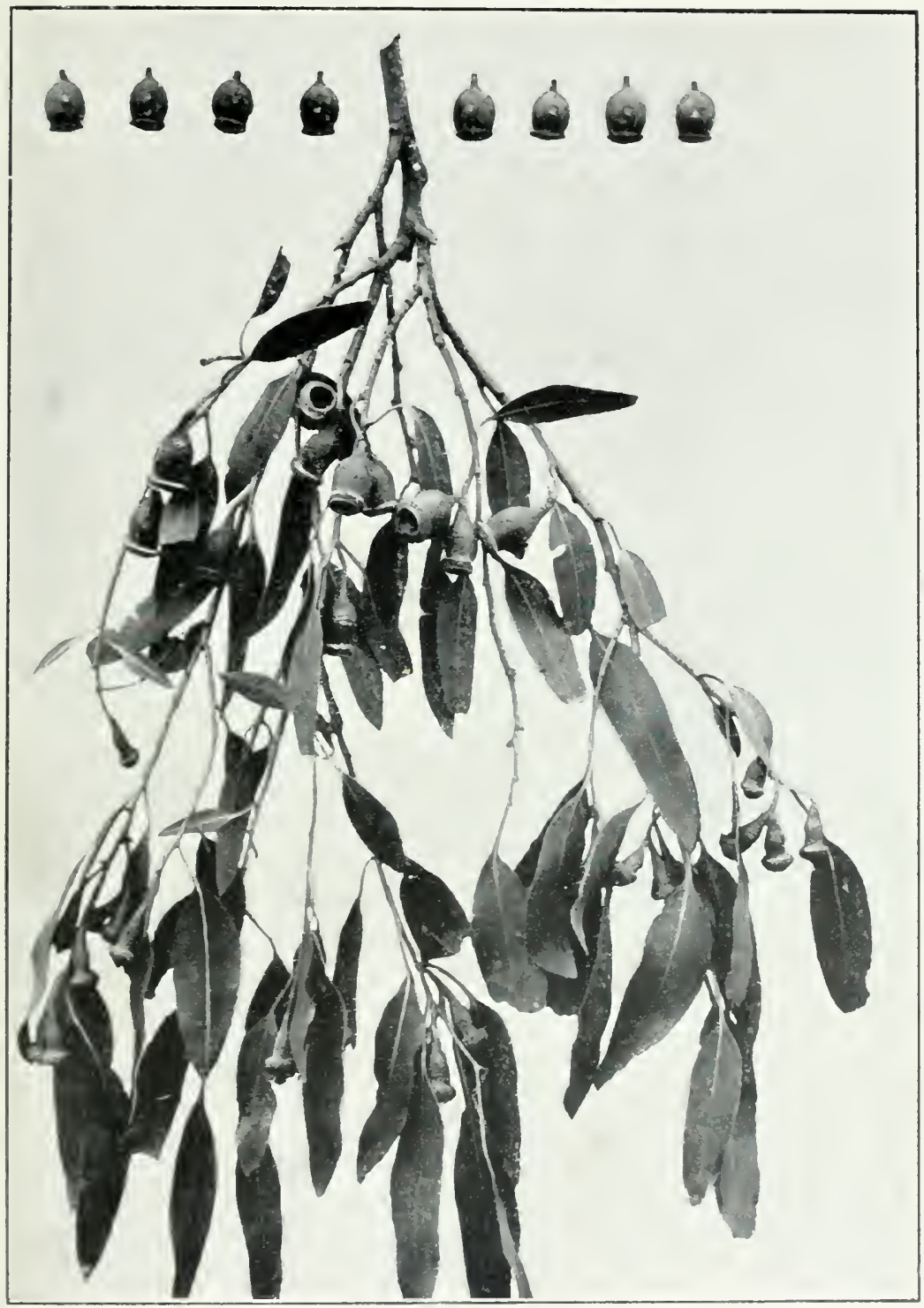

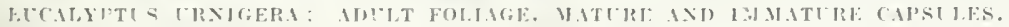
l'lute $\{1$.

[Fice p. 94. 

The following species are dealt with in their order of hardiness as observed by the writer:-

- S. E. panciflora-syn. E. coriacea (White or Drooping Gum) (Plates 48 and 49 ). - This is rather a spreadiug-branched tree. with smooth white bark. The timber is not durable in contact with the grouni, but is excellent for general builłing purposes and firewood. It is soft, easily solit, and much lighter in colour than most of the Eucalypts. Together with E. Gumnii, it ascends to $4,000 \mathrm{ft}$. in Tasmania, at which elevation it becomes a mere shrub; while at lesser elevations specimens fully $100 \mathrm{ft}$. high, with a diameter of $4 \mathrm{ft}$., are frequent. Moist open soils seem to suit it best, although it may be found doing well on almost pure gravel. This species was not killed (although slightly damaged) with $14^{\circ}$ below zero, or $46^{\circ}$ of frost at Ranfurly, in central Otago. At Hanmer Springs the young growth was frosted, but the plants were otherwise unhurt with $32^{\circ}$ of frost in July, 1903.

E. Gumnii (Cider Gum) (Plates 6.2 and 63)._-Acording to Mueller, this tree is found in alpine regions in Australia up to 5,600 ft. It is found hariy in many places in Scotland, and at Kew Gariens, London. Large trees have survived $32^{\circ}$ of frost at Queenstown and other portions of southern Otago, but it succumbed at $\delta^{3}$ belo ir zero in central Otago. This species varies considerably in size, from a mere bush to $200 \mathrm{ft}$. high. In habit it is sometimes spreading, and frequently of crooked growth, although perfectly straight specimens occur. The bark is smooth and light-coloured, the young leaves round or oval, in opposite pairs, and the flowers and seedpods are nearly always produced in threes. The wood is hard and durable if cut from old trees and well seasoned before use. It makes excellent fuel. Almost any soil seems to suit the Cider Guın, from diry gravel to stiff clayey loam. It is very fast-growing in the young state, but only moderately so later. Consilerable confusion exists with regard to this species owing to the seed of several other kinds having been imported and grown as the true Cider Gum. E. Stzartiana and E. riminalis are both in cultivation under the name of $E$. Gunnii, which species they resemble.

E. coccifera (Mountain Peppermint Gum) (Plates 60 and 61).This hardy species is frequent up to $4,000 \mathrm{ft}$. in Tasmania. It has stood $23^{\circ}$ of frost in England without injury, and the tree is now $78 \mathrm{ft}$. in height. Although closely allied to E. amygdalina it is much nore hardy than that species, ani has thicker leatinery leaves, and much larger seed-capsules, generally in threes. It has a teniency to a tall central stem, frequently rising to $150 \mathrm{ft}$. The timber is heavy, redidisn, and extremely ciurable. Naturally it grows amongst rocks and on poor gravelly soils, at fairly high altitudes. Messrs. Cresswell, seed-collectors, of Hobart, consider the Mountain Peppermint Gum the hardiest of all the Eucalypti.

E. urmegera (Urn-bearing Gum) (Plates 46 and 47).- This species can be easily identified when in seed by its capsules, which 
are shaped like a Grecian urn. The bark is smooth, ashy-white in colour, and the timber is hard, heavy, and durable. It grows into a fine straight-stemmed tree, frequently over $100 \mathrm{ft}$. The foliage is more dense than $E$. coccifera, but otherwise it much resembles that species. Excellent specimens of this tree are to be found in Canterbury and Southland, where it withstood the cold of the past winter without damage, while in the south of Scotland, York, and Devon it has suffered but little injury during thirty years' growth. It is found only in the cool and elevated ranges of Tasmania.

E. Mucllerii (known in Tasmania as the Mountain Red Gum) (Plate 59).-This species must not be confused with E. Muelleriana, one of the stringy-barks from Gippsland. This is a comparatively new species, found in alpine situations in Tasmania, where it is said to attain fully $200 \mathrm{ft}$., and often $100 \mathrm{ft}$. without a single branch. The bark is smooth and green, marked with reddish-brown blotches. The wood is light red, very hard, heavy, and stringy, but owing to its recent introduction no proof of its durability has yet been established. The leaves are oblong, nearly or quite equal-sided, thick, and polished on both surfaces. It has withstood $26^{\circ}$ of frost in Otago without damage, and, according to Hooker, it is hardy at Kew Gardens, London.

E. Stuartiana (Apple-scented Gum) (Plates 55 and 56).--This is the fastest-growing of all the hardy Eucalypts, and, as it produces heavy and durable timber in a comparatively short time, is very hardy, and transplants easily, it should he extensively cultivated. It is widely spread over south-eastern Australia and Tasmania, and seems to prefer moist sandy soils. Frequently it attains over $100 \mathrm{ft}$. on river-banks. Planted in the open it makes rather spreading branches, but when grown close together it forms a massive bole with slender drooping branchlets. The leaves are sickle-shaped, dark green, and shiny on both surfaces. The bark is brownish, scaly on the outside and fibrous within. Handsome specimens of this tree may be seen on Corporation reserves at Invercargill.

E. Siebcriana (the Yowut or Mountain Ash of New Sourh Wales, aud the Ironbark of Tasmania) (Plate 50). - This is a lofty, straighttrunked tree, which attains fully $100 \mathrm{ft}$. in height and $5 \mathrm{ft}$. in diameter. The bark is of a dark-brown colour and deeply furrowed, the branches are sinooth and pale, the leaves sickle-shaped, shiny, and of nearly the same colour on both sides. In Tasmania the timber is used for piles, posts, and builders' scantling. It is strong and elastic, and burns well, even while green. Large specimens are not uncommon in Otago and Southland, and at Rotorua small plants have withstood $20^{\circ}$ of frost without injury. It is remarkable that this species was killed during the winter of 1899 at Greendale, Canterbury, and yet in other extreme localities it was not even damaged.

E. amygdalina (Almond-leaved Peppermint Gum) (Plates 44 and 45).- This species is termed "Black Peppermint" by the log-getters 


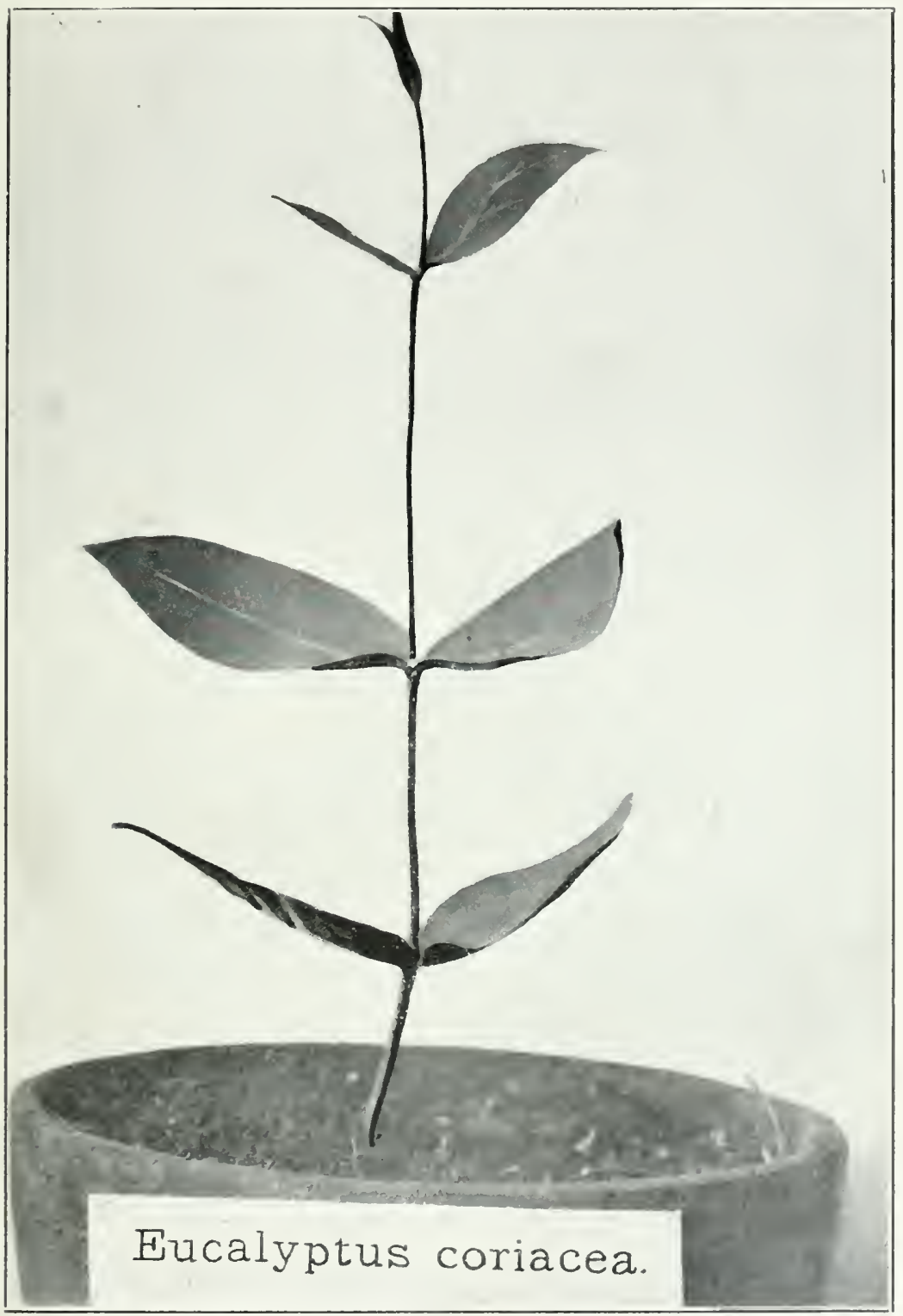

ELCAIYPTES PACCIFLORA (SIX. F. CORIACHA) SEEDLING, SIX IONTHS OLD). Tlute 48.

[Fuce 1). 96. 

in Tasmania. The timber is very variable in quality, depending on the nature of the soil in which it is grown. According to Mr. A. O. Green, author of "Tasmanian Timbers," "The timber grown on dry ridges supplies the most durable wood of any of the gums, and where timber is used in contact with the ground, such as piles and posts, it is always specified to be of Black Peppermint." The rate of growth has been recorded in France as $50 \mathrm{ft}$. in eight years. At Rotorua one season's growth measured $\delta \mathrm{ft}$., whilst the annual average growth in New Zealand may be set down as $6 \mathrm{ft}$. To be such a rapid grower it is fairly hardy, having encountered $20^{\circ}$ of frost in several parts of New Zealand without damage. Cultivators requiring seeds of this tree should endeavour to procure their supplies from Tasmania (where it is found growing up to $4,000 \mathrm{ft}$.), rather than from Victoria, New South Wales, or Gippsland, as seedlings raised from seed procured from the former place will prove much hardier than those coming from the warmer climates mentioued. Although it will grow on any soil that is not wet, dry poor soils are the best for producing lasting timber. The branchlets are slender and drooping; leaves thin, shiny on both surfaces, and very variable in shape-frequently $3 \mathrm{in}$. to $4 \mathrm{in}$. long and only $\frac{1}{4}$ in. in width, while they are occasionally found nearly $1 \mathrm{in}$, in width and $4 \mathrm{in}$. to $6 \mathrm{in}$. in length. The bark is also so exceedingly variable that auy attempt at description would be misleading. The only reliable means of determining the identity of this species is by the ripe capsules, as showu on Plate 64. Amongst a large number examiued there is only a variation in size (see Figs. 1 and 9), the shape being always constant. The specific name amygdalina is not happily chosen, as the foliage in no way resembles that of the Almond-tree. It is this species of Eucalyptus that yields the largest percentage of Eucalyptus-oil, no less than $500 \mathrm{oz}$. being distilled from $1,000 \mathrm{lb}$. weight of fresh leaves. The yield from E. globulus is given at 120 oz., and from E. viminalis only $7 \mathrm{oz}$. from the same weight of leaves.

E. regnans (Swamp Gun of Tasmania) (Plates 53 and 54). - This tree much resembles $E$. amyqdalina in many respects, and in some forms is difficult to distinguish from that species. The leaves are broader and more sickle-shaped, while the branchlets are reddish. In vertical growth it exceeds the largest Big Tree of California by $21 \mathrm{ft}$, a specimen found at Mount Bau-Bau measuring $471 \mathrm{ft}$. It is bardy at Greenciale, Canterbury, also at Rotorua and at Invercargill, resisting $22^{\circ}$ of frost without injury. Its rate of growth and the quality of the timber produced is much influenced by climate and soil. Cool, sheltered gullies, neither too hot in summer nor too cold in winter, seem the most favourable situations for rapid growth. The timber is not lasting in contact with the ground, but is of great strength, ranking third amongst Tasmanian timbers in breakingstrain, E. obliqua and Blue-gum being the strongest. It is largely used for furniture, house-building, and inside fittings in Tasmania and Australia.

Forestry-4. 
E. obliqua (Stringy-bark) (Plates 51 and 52).-The specific name is given from the leaf being unequally divided by the midrib, and from the leaf-stalk springing fron one side obliquely, and not from the middle portion of the leaf. The name "stringy-bark" is applied owing to the fibrous nature of the bark, which is of great thickness. As some nine or ten species of Australian Eucalypti are called "Stringy-barks" this designation is somewhat confusing. The true Stringy-bark is frequently found up to $300 \mathrm{ft}$. in height, with a diameter of $10 \mathrm{ft}$., growing mostly in hilly country and in poor soil. The timber varies considerably, according to the situation and soil in which the tree grows, the most durable quality always being found on poor dry riages. It is the strongest of all Tasmanian timbersa piece $12 \mathrm{in.} \mathrm{long} \mathrm{and} 1 \mathrm{in}$. square, supported at each end, having stood the test of $1,220 \mathrm{lb}$. weight on its centre before breaking. It is this tree which produces the bulk of the timber exported from Tasmania under the name of "hardwood." It is fairly hardy in this colony, having withstood $26^{\circ}$ of frost in Southland, but at Queenstown it was killed when the thermometer reached zero.

E. viminalis (Manna Gum) (Plate 57).-The highest specimen of this tree recorded measured $320 \mathrm{ft}$., with a diameter of $17 \mathrm{ft}$. The silvery-white bark exudes a peculiar substance resembling sugar icing. The timber is reddish when green, changing to a light yellow when seasoned. It is not durable underground, although a useful builders' material for house-framing. Poor sandy soils (according to Mueller) seem to produce the best quality of timber. The flowers and seed-pods are nearly always produced in threes. It is hardy in Southland, Oamaru, Timaru, Marlborough, and Rotorua. The only place where specimens have been noted as killed is Queenstown.

$E$. hcmostoma (Gum-topped Stringy-bark). - Although this is a hardy tree and does well on poor soil its timber is of little value except as fuel. It is a tall-growing species, with few branches, bark smooth except near the base, where it is rough and fibrous. The leaves much resemble those of $E$. obliqua.

E. globulus (Blue-gum) (Plate 58). - This tree is too well known to require description. New - Zealand-grown timber has frequently been condemned as useless owing to its soft spongy nature, but, as pointed out elsewhere, this defect is entirely due to want of maturity. All Eucalypti grow with great rapidity, but the formation of heartwood is a comparatively slow process, and the fact that a gum-tree has grown to a large size is no criterion that the tree is mature for felling. On heavy, moist solls the formation of heartwood does not keep pace with the growth of the tree, but on poor, dry, light soils the heartwood matures at a much more rapid rate. A tree grown on the latter class of soil may be fit for felling in from twenty-five to thirty years, while forty to fifty years' growth may be necessary to mature the timber of a tree grown in heavy, damp soils. Owing to the destruction of the leaves by an insect 


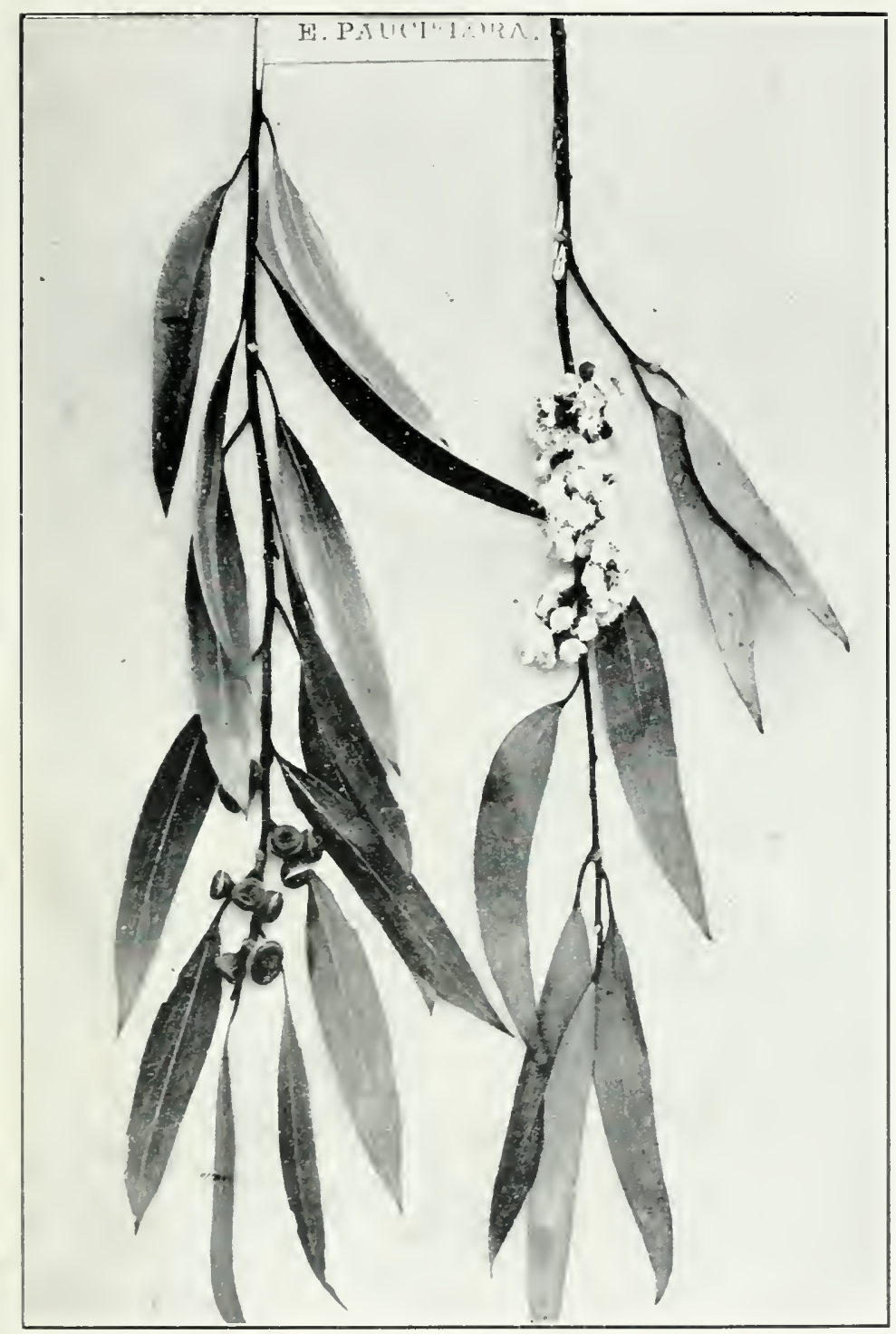

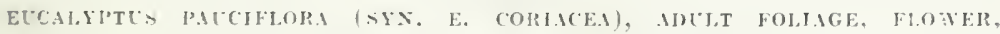
AXI) RIPE CIISTIFS, OXE-HIHF XITIRAL SIZE.
['late 49.]
[Face 1). 98. 

extensive planting of the Blue-gum has practically ceased. This pest, at one time more prevalent in the North Island, has during the last few years gradually worked its way south, until both Islands are now equally affected by its depredations.

Amongst the more hardy Australian Eucalypti proper, E. tereticornis (Red-gum of Queensland) has so far been proved to be the hardiest of forty species experimented with. Its growth is exceedingly rapid, even on the poorest soils, although it transplants less successfully than most other species. The timber is prized for its durability, especially for sleepers and posts, and for other purposes where it is used in contact with the soil. 




\section{A P PENDICES.}

\section{APPENDIX I.}

\section{ALPHABETICAL LIST OF TREES AND SHRUBS SUIT- ABLE FOR PLANTING IN NEW ZEALAND FOR TIMBER, SHELTER, OR ORNAMENT.}

$x^{2}$ the following list European and Asiatic trees have been revised in accordance with "Index Kewensis," American trees under the authority of "Nomenclature of the Arborescent Flora of United States," whilst Australian and New Zealand trees have been classed under the authority of the late Baron Sir Ferdinand von Mueller, the late Professor Kirk, and Mr. T. F. Cheeseman, F.L.S., respectively.

It will be noted that many familiar names have been relegated to "synonyms"-e.g., Pinus insignis is now Pinus radiata, Abies Douglasii is Pseudo-tsuga taxifolia, Podocarpus spicatus is Prumnopitys spicatus, \&c. These changes in nomenclature are the result of close investigation by the most eminent botanists of the day, who have discerned important structural characteristics (omitted in the first published description of species), thus necessitating such alterations. It is of the utmost importance that the correct botanical designation of a tree should be stated, owing to the misuse of popular names, which cause confusion as well as annoying inconveniences and misunderstandings when ordering trees or seeds from a nurseryman, who may supply an order with an entirely different kind from that which was intended. Where synonyms are given it may possibly obviate errors if both the botanical name as well as the synonym are stated in ordering supplies.

The popular name of each tree is added where a recognised one exists, in other cases the scientitic name is expressed in its English equivalent. The synonyms are given in parenthesis, while evergreen or deciduous trees are shown by the use of the letter "E." or "D." after the approximate height of each species. 
ACacia DEalbata-Silver-wattle.-South-eastern Australia and Tasmania. $150 \mathrm{ft}$. E. Good shelter and ornamental tree. Produces exoellent fuel of great heating-power. The hardiest of the Wettles; does well on poor land.

Acacia Decurrens - Black or Tan Wattle. - New South Wales. $50 \mathrm{ft.}$ E. Good shelter and ormamental tree. Bark rich in tannin; first-class fuel. Succeeds best in poor dry soils at low elevations near the sea.

ACACia Melanoxylon-Blackwood or Lightwood.-South-eastern Austraiia and Tasmania. $80 \mathrm{ft}$. E. A good shade and timber tree. Timber hard and durable, suitable for furniture and cabinetwork. Medium hardy except in inland soutbern districts; prefers deep loamy soils.

ACACIA PYRACANTHA - Golden-wattle. - Victoria and South Australia. $30 \mathrm{ft}$. E. Rapid-growing ornamental tree; excellent shelter. Bark yields tan. nin; timber fair firewood. Medium hardy; poor sandy soils, coastal situa. tions.

Acer Campestre - British Maple. - Europe, Asia, Africa. $40 \mathrm{ft}$. D. Ornamental and of quick growth. Produces compact and fine-grained timber. Very hardy, stands the dry atmosphere of the Canterbury Plains remarkably well.

ACER MaCrophyllum - Oregon Maple. - British Columbia and New Mexico. $90 \mathrm{ft}$. D. Fine shade-tree; large ornamental leaves. Timber hard and close-grained. Does best on river-banks; hardy. Inner bark used for mats, \&c.

Acer saccharinum (A. Dastcarpum)--Silver-maple. - North America. $50 \mathrm{ft}$. D. Excellent street-tree, ornamental and shade; no value as timber. Deep loam on gravelly bottom; hardy.

ACER RUBRUM-Red-maple.-North America. $100 \mathrm{ft}$. D. Excellent stree: tree; yields maple-sugar. Deep loam on gravelly bottom; hardy; requires plenty of moisture.

ACEr NEgUNdo (Negundo ACEroIdes) - Box-elder. - North America. $50 \mathrm{ft}$. D. Handsome shade-tree; chiefly for ornament and shade, but also supplies "curled maple" for veneers. Heavy fertıle soil ; hardy.

Acer saccharum (A. Saccharinum)-Sugar-maple.-100 ft. D. $3 \mathrm{ft}$. to $4 \mathrm{ft}$. in diameter. Excellent shade-tree; ornamental timber for cabinetwork. Near rivers and streams, on rich swampy land; hardy.

ACER SACCHARUM NigRUM (A. Nigrum)-Black-maple.-North America. $80 \mathrm{ft}$. to $100 \mathrm{ft}$. D. Variety of above. Furnishes " bird's-eye maple" timber, and saccharine fluid for sugar-making. The true sugar-maple. Friable, cool moist soil ; hardy.

Acer Platanoides - Norway Maple.-Europe. $50 \mathrm{ft}$. to $80 \mathrm{ft}$. D. Dense compact growth; foliage golden yellow in autumn. Same as above, excellent fuel. Deep moist soils; hardy.

ACER PSEUdO-PLATANUS-Sycamore or Spurious Plane.-Europe and Asia. $100 \mathrm{ft}$. D. Fast-growing and easily raised. Timber for ornamental use, turnery, \&c. Any soil; cool and moisture-loving; hardy.

Aisculus Californica-Californian Buckeye.-California. $50 \mathrm{ft}$. to $60 \mathrm{ft}$. D. Beautiful spreading branched tree. Cabinetwork and deiry utensils. Any soil or situation if not wet; hardy; prefers cool climate.

Aisculus Hippocastinum-Horse-chestnut.-South-eastern Europe. $60 \mathrm{ft}$. D. Showy and fast-growing; ornamental; bears snow-white flowers; one of the best trees for street-planting. Deep soil, sheltered positions; hardy.

AEsculus RUBicanda (A. CARNEA)-Red-flowering Chestnut.-North America. $20 \mathrm{ft}$. D. Very fine flowering-tree; ornamental only; produces large trusses of red flowers. Deep soils, sheltered positions; hardy.

abies pectinata (Pinus abies, Picea pectinata)-Silver-fir.-Central Europo. $100 \mathrm{ft}$. to $150 \mathrm{ft}$. E. Fine summetrical growth; largely grown for timber purposes in Europe. Deep soils, sheltered positions; hardy. 


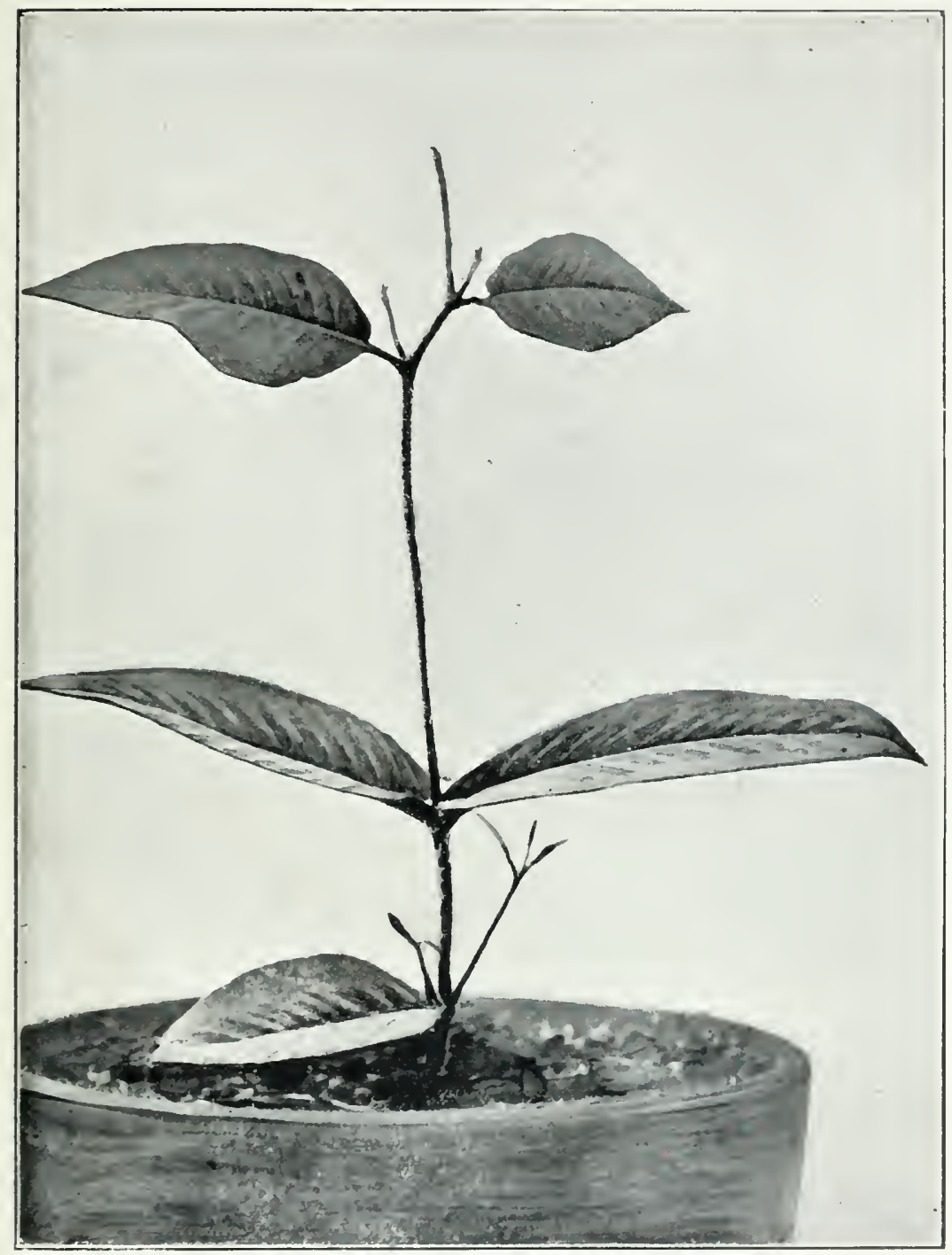

Plute :51.]

EUCALYPTES OBIIQUA SEEDLING, SIX NONTIIS OID.

[Fuce p. $10 \Omega$. 

Abies balsamea (Picea balsamea) - Balsam Fir.-North America. $40 \mathrm{ft}$. to $60 \mathrm{ft}$. E. Well-formed pyramidal tree. Timber for general builäing purposes. Prefers good deep loam; good shelter; tender and slow.growing when young.

Abies amabilis (Picha amabilis) - Lovely Silver-fir.-British Columbia, Oregon. $200 \mathrm{ft}$. to $250 \mathrm{ft}$. E. Handsome, densely foliaged, pyramidal habic; chiefly ornamental. Deep, ricb, moist, and eool soils; hardy.

Abies venusta (A. BRacteata)-Bristled-coned Fir.-South Californian mountains. $100 \mathrm{ft}$. to $150 \mathrm{ft}$. E. Slender, straight growth; very ornamental. General building purposes. Does well on dry gravelly lands; hardy.

Abies grandis (Picea Grandis)-Lowland Silver-fir.-Pacific Coast. $200 \mathrm{ft}$. to $300 \mathrm{ft}$. E. Splendid quick-growing symmetrical tree; chiefly ornamental. Good soll, at consıderable elevations ; bardy.

Abies dragnifica (Picea magnifica)-Red Silver-6ir.-California. $100 \mathrm{ft}$. to $200 \mathrm{ft}$. E. Beautiful pyramidal tree, fast grower. Joinery-work and inside fittings. Noist valleys at high elevations; hardy.

Abies robilis (Picea nobilis)-Noble Silver-fir.-North California. $150 \mathrm{ft}$. to $250 \mathrm{ft}$. E. Magnificent tree, regular horizontal spreading branches. Strong, durable, and elastic timber; suitable for beams, \&c. Good soil, well above sea-level; hardy.

Abies CoNcolor (Picea CONCOLOR) - White Silver-fir. - California, Rocky Mountains. $120 \mathrm{ft}$. to $150 \mathrm{ft}$. F. Excellent ornamental tree. Timber of second rate, chiefly for landscape effect. Any well-drained soil ; hardy.

Abies fraserit (Picea Fraseri) -Fraser's Silver-fir.-North Carolina. $30 \mathrm{ft}$. to $40 \mathrm{ft}$. E. Higbly ornamental. Tough and durable timber, does not shrink or warp. Any well-drained soil ; hardy.

Abies nordianiana (Picea nurdmanniana) - Nordman's Fir. - Crimea Caucasus. $100 \mathrm{ft}$. to $125 \mathrm{ft}$. E. The hardiest of the Silver-firs. Timber o excellent quality. Medıum soil, veither wet nor dry; hardy.

Abies webblana, var. PINDrow (Picea PINDrow)-Indian Silver-fir.-Eaat Himalayas. $75 \mathrm{ft}$. to $100 \mathrm{ft}$. E. Upright ornamental species. Soft, spongy timber. Light loamy and porous soll; hardy.

Abies pixsapo (Picea Pinsapo)-Spanish Silver-tir.-70 ft. to $80 \mathrm{ft}$. E. Good lawn tree; cylindrical shape. Highly resinous timber of great durability. Sheltered situations, porous soil; hardy; does well on the dry plains of Canterbury.

Abies webbiana (Picea webbiana)-Webb's Indian Fir.-Himalayan Mountains. $70 \mathrm{ft}$. to $90 \mathrm{ft}$. E. One of the prettiest of the Silver-firs. Chiefly ornamental; timber spongy. Sheltered situations, porous soil; tender when young.

Ailanthus glandelosa (A. Japonica)-Tree of Heaven.-China. $60 \mathrm{ft}$. D. Very ornamental avenue-tree. Pale-yellow wood, very durable. Succeeds well in any soil, stands coast gales; hardy.

Alectryon Excelser - Titoki. - New Zealand. $40 \mathrm{ft}$. to $60 \mathrm{ft}$. E. Good shade-tree; ornamental effect only. Any ordinary soil; suitable for situations on northern coasts.

Agathis australis (Damara a dstralis)-Kauri.-New Zealand. $180 \mathrm{ft} . \quad$ E. Well-known tree; too slow in growth for timber-culture. Northern coasts only ; content with a ay poor soil.

Ackama rosefolia-Makamaka.-New Zealand. $20 \mathrm{ft}$. to $50 \mathrm{ft}$. E. Highly ornamental, for scenic effect. Northern coars only; content with any soll.

AcNuS Glutixosa-Alder.-Europe and Asia. $50 \mathrm{ft}$. to $90 \mathrm{ft}$. D. Handsome umbrageous tree. Very durable timber under water; soft and light. Any moist land, even bogs; hardy. 
AradCARIA BIDwilliI-Bunya-Bunya.-Queensland. $250 \mathrm{ft}$. E. Symmetrical tree. Fine-grained, hard, durable wood. Deep porous soil ; North Island only.

Aratcaria Brasiliexsis-Brazilian Araucaria.-Brazil. $75 \mathrm{ft}$. to $100 \mathrm{ft}$. F. Symmetrical tree. Timber for masts and spars, though chiefly for ornament. Deep porous soil ; hardy in inland Canterbury.

AracCaria cookil-Captain Cook's Pine.-New Caledonia. $100 \mathrm{ft}$. to $150 \mathrm{ft}$. E. Symmetrical tree, chiefly ornamental. Deep porous soil ; North Island only.

Aradcaria cunninghami-Moreton Bay Hoop-pine. - Eastern Australia. $200 \mathrm{ft}$. E. Fine-grained, strong, and durable timber. Deep porous soil ; North Island only.

Araucaria excelsa-Norfolk Island Pine.-Norfolk Island. $200 \mathrm{ft}$. E. Tree of unsurpassed symmetry, chiefly for ornamental planting. Any soil not wet, near the cosst; northern New Zealand.

Aradcaria mibricata - Monkey.puzzle. - Chili and Patagonia. $150 \mathrm{ft}$. E. Tree of unsurpassed symmetry. Hard durable timber, chiefly for ornamental specimens. Any well-drained soil; hardy anywhere, except central Otago, where it was killed by frost in 1903.

Arbutus Menziesil - Madrona. - North-western America. $150 \mathrm{ft}$. E. Fastgrowing and good shelter. Timber exceedingly hard. Deep loamy soil, sheltered valleys; hardy.

Ascarina lucida-Hutu.-New Zealand and Pacific Islands. $25 \mathrm{ft}$. E. Ornamental tree-a choice New Zealand tree. Northern coasts only.

Betula ALBA-Silver-birch. - Europe. $40 \mathrm{ft}$. to $80 \mathrm{ft}$. D. Well-known tree. Excellent shelter when planted close. Timber of little value; ornamental. Content with the poorest soil in any situation; hardy.

Betula Lenta-Cherry or Sweet Birch.-North America. '80 ft. D. Tree of quick growth. Heavy fine-grained furniture timber. Prefers moist soil at high elevations; very hardy.

Betula NigRA-Red or River Birch.-North America. $80 \mathrm{ft}$. D. The tallest of the Birches. Timber excellent for cabinetwork. Banks of rivers and streams; hardy.

Betula Papyracea--Paper-birch.-North America. $100 \mathrm{ft}$. D. Fine ornamental tree. Fine-grained timber, used for canoes. Does best in cool situations, any soil ; very hardy.

Brachychiton acerifolius - Flame-tree.-Eastern Australia. $60 \mathrm{ft}$. E. Rapid growth, magnificent trusses of crimson flowers. Suitable for North Auckland only.

Buxus sempervirexs-Boxwood-tree.-Europe and Asia. $30 \mathrm{ft}$. E. Slowgr wing; produces valuable timber for engraving. Hardy, and grows well in any soil; easily raised from cuttings.

Beilschmieda tawa (Laurus Salicifolia)-Tawa.-Northern New Zealand. $50 \mathrm{ft}$. to $80 \mathrm{ft}$. E. Well-known native tree. Yields fair timber, good firewood. Suitable for nortbern districts only.

Beilschmiedia taralri (Nesodaphne tarairi)-Tarairi.-Northern New Zealand. $60 \mathrm{ft}$. to $80 \mathrm{ft}$. E. Exceedingly nandsome. Timber of doubtful value; should be grown largely as an ornamental tree. North Auckland only.

Callitris arborea (Widdringtonia juniperoides)--Sandarac Tree.-Southern Africa. $100 \mathrm{ft}$. E. Immense tree, handsome. Yields the well-known sandarac gum. Very hardy, and attains extraordinary girth of stem.

Callitris verrucosa (Frenela verrdcosa)- White Cypress-pine.-Australia. $100 \mathrm{ft}$. E. Ornamental. Tumber lasting and insect-proof. Endures extreme drought; suitable for sandy wastes. 


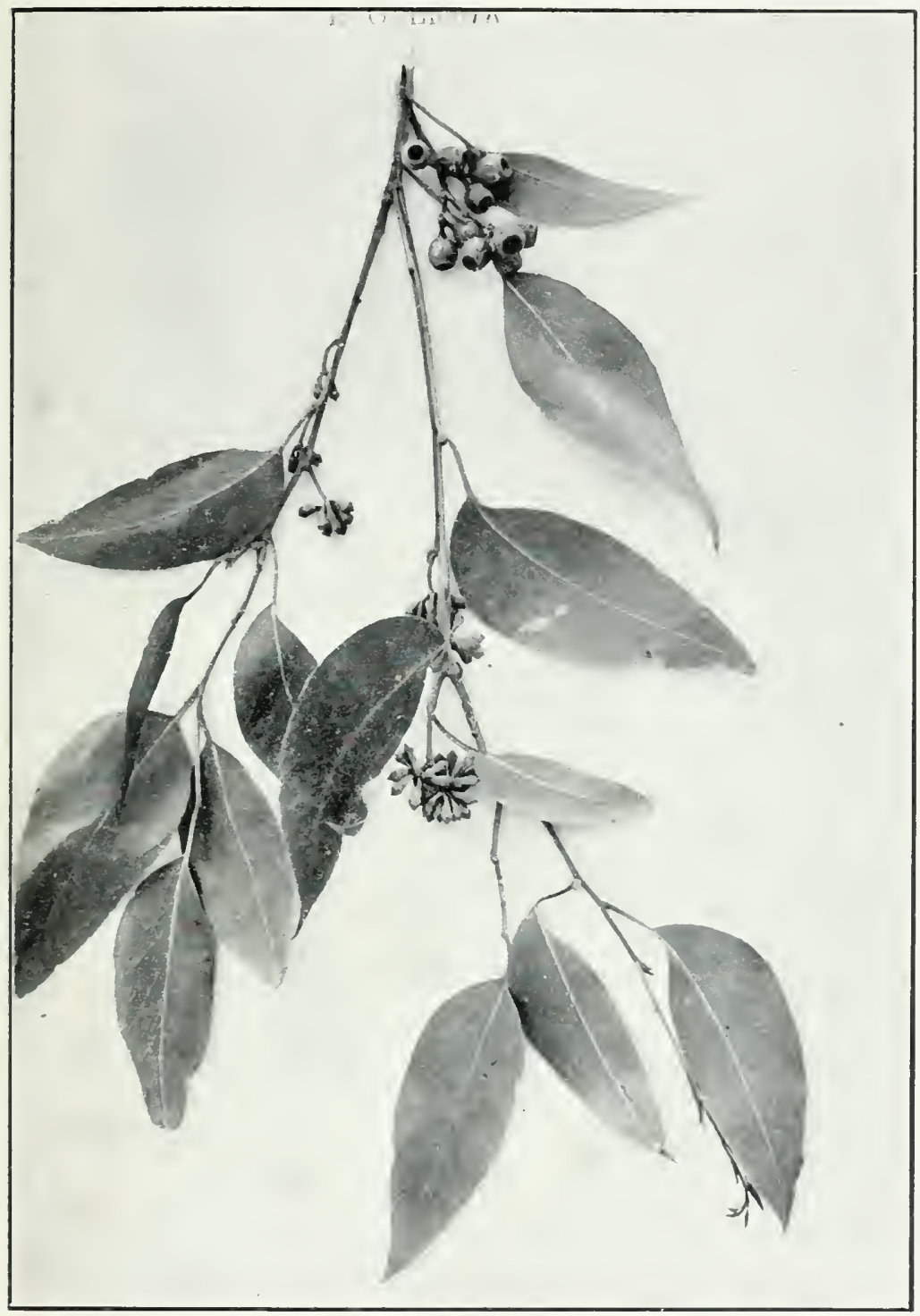

ECCALYPTUS OBLIQUA, ADULT FOLIAGE, RIPE AYD UXRIPE CAPSLLES, ONF-HALF Plate 5.2.] NATUPAL SIZE.

「Fuce p. 104. 

Callitris calcarata (Frenela endlicheri)-Red or Black Pine.-Eastern Australia. $70 \mathrm{ft}$. E. Ornamental. Timber lasting and insect-proof. Endures extreme drought; suitable for sandy wastes.

Callitris robusta (Frenela robusta)-Cypress-pine.-Victoria and New South Wales. $100 \mathrm{ft}$. E. Durable timber. Sandy barren lands; fairly hardy.

Callitris australis (Frenela australis)-Tasmanian Cypress.-Tasmania. $30 \mathrm{ft}$. E. Ornamental. Yields valuable timber. Poor soils; hardy.

Carpinus betulus-Hornbeam.-Southern Europe, Western Asia. $80 \mathrm{ft}$. D Tough and durable timber. Very hardy tree; useful as a fire-stop.

Carpixus carolisiaxa (C. americanus) - Water or Blue Beech.-North America. Soft. D. Fine-grained, tough timber. Hardy; does best near streams.

Carpodetus Serratus-Puta-puta-weta.-New Zealand. $30 \mathrm{ft}$. E. Elegant light-green foliage, of ornamental value only. Hardy ; any ordinary soil.

CARYa tomextosa (Hicora ALBA) - Shell or Shag-barl- Hickory.-Eastern North America. $90 \mathrm{ft}$. to $100 \mathrm{ft}$. D. Mlakes a good street-tree. Heavy, strong, and elastic timber, used extensively for carriage-building. Hardy; deep fertile soils.

CARYa olifeformis (Hicora PECAN)-Pecan-nut Hickory.-Eastern North America. $70 \mathrm{ft}$. to $80 \mathrm{ft}$. D. Mlost rapid growing of the Hickories. Hardy; deep fertile soils.

Carya porcina (Hicora glabra)-Pig-nut Hickory.-Eastern North America. $40 \mathrm{ft}$. to $100 \mathrm{ft}$. D. Shiny-green leaves. Wood very tough; principally used for axe-bandles. Hardy; deep fertile soil.

CARYA ALBA (HICORA OVATA)-Shag-bark Hickory.-Eastern North America. $50 \mathrm{ft}$. to $100 \mathrm{ft}$. D. Erect-growing tree. Wood very tough; principally used for axe-handles. Hardy; moist deep soil.

CARYa AMARA (Hicora minima)-Bitter-nut Hickory.-Eastern North America. $50 \mathrm{ft}$. to $80 \mathrm{ft}$. D. Very handsome tree. Timber less valuable than above. Hardy; low wet ground.

Coryxocarpus Lefigata-Karaka. -New Zealand. $25 \mathrm{ft}$. to $30 \mathrm{ft}$. E. Compact, glossy, splendid shelter-tree, of quick growth. Hardy only on the cosst in the South Island; stands salt spray.

Castaxea Sativa (C. TEsca)-Sweet or Spanish Chestnut.-Europe, Asia, $60 \mathrm{ft}$. to $80 \mathrm{ft}$. D. Excellent shade-tree. Strong, aurable timber for posts, \&c. Very hardy; does well in any alluvial soil. Should be sown in situ.

Castanea Dextata (C. vUlgaris, var. Americana)-American Sweet Chestnut.-North America. $100 \mathrm{ft}$. to $150 \mathrm{ft}$. D. Excellent shade-tree. Strong, durable timber. Merely the American variety of above.

Catalpa speciosa (Bignonia Catalpa)-Hardy Catalpa.-North America. $60 \mathrm{ft}$. to $80 \mathrm{ft}$. D. Highly ornamental. Very lasting timber; quick growth. Hardy; porous deep soils.

Catalpa Bigroxoides-Indian Bean.--Southern United States. $40 \mathrm{ft}$. to $60 \mathrm{ft}$. D. Spreading tree; quick growth; chiefly for ornament. Hardy; porous deep soils.

Castarina eqdisetifolia (C. Littorea)-Bull or Forest Oak.-East Africa, Southern Asia, North Australia. $180 \mathrm{ft}$. E. Fast-growing. Exceedingly durable timber. Does best near the coast, even at high-water mark.

CASCARITA QUADRIVALVIa (C. SThICTA)-Forest Swamp-oak.-South Australia. $60 \mathrm{ft}$. E. Drooping foliage; timber and shade purposes. Grows well on pure cosstal sands; easily raised.

Casuarisa tordlosa--Beefwood.-New South Wales, Queensland, South Augtralia. $80 \mathrm{ft}$. E. Very handsome. Durable furniture-timber. North Island only.

Castarina glatca - Desert She-oak.-Australia. $70 \mathrm{ft}$. E. Rapid-growing tree; shelter and timber. North Island only. 
Cenrus ajlantica (Pinus atlantica)-Mount Atlas or African Cedar.-80 ft. E. Attains huge dimensions; ornamental and timber. Hardy; free open soil.

Cenrus deodara (C. INdiCa) - Indian Deodar Cedar.-Westerb Himalayas. $150 \mathrm{ft}$. to $200 \mathrm{ft}$. E. Drooping, spreading tree. Produces indestruotible timber, but slow growth. Does well in any soil or situation; hardy except in central Otago.

Cenrus libana (Pinus cedrus)-Cedar of Lebanon,-Lebanon, $60 \mathrm{ft}$. to $80 \mathrm{ft}$. E. Fine lawn-tree; timber, shelter, and ornamentals Hardy in all situations except central Otago.

Condrline australis (Dracana australis)-Palm Lily or Te Kouka.-New Zealand. $25 \mathrm{ft}$. E. Well-known tree; ormamental, and for shelter on seacoasts ; easily raised from seed.

Cordiline indivisa (Dracerena indivisa)-Toi.-New Zealand. $15 \mathrm{ft.}$ E. Remarkably handsome, ornamental. Requires partial shade, open deep soil, and plenty of moisture.

Chamectparis lawsoniana (Cupressus lawsoniana) - Lawson's Cypress, or White Cedar.-Nortbern California. $75 \mathrm{ft}$. to $100 \mathrm{ft}$. E. Graceful pyramidal growth; guod shelter, and durable building-timber. Hardy in any part of New Zealand ; easily grown.

Chamectparis Nutkensis (Thujopsis Borealis) - Yellow - cedar. - Sitka, Washington, Oregon. $100 \mathrm{ft}$. E. Fast growing, tapering habit; durable timber and shelter. Hardy; free loam or sandy soil.

Chamectparis throides (C. SpHeridea, or Retinospera ericoides)-Whitecedar.-Eastern United States. $80 \mathrm{ft}$. H. Handsome tree. Exceedingly durable timber. Moist swampy land; hardy.

COROKIA BDDDLEOIDES-Korokia.-North Island, New Zealand. $6 \mathrm{ft}$. to $12 \mathrm{ft}$. E. Dense-growing shrub; orange berries; ornamental and sheiter. Very hardy ; any soil.

Corokia cotoneaster.-New Zealand. $6 \mathrm{ft}$. to $10 \mathrm{ft}$. E. Tortuous, black, interlacing branches; ornamental. Hardy; rocky soil.

Coprosma GRANDIFLORA - Kanono, or Raurekau. - Northern New Zealand. $6 \mathrm{ft}$. to $15 \mathrm{ft}$. E. Large-leaved; upright growth; orange berries ; shelter and ornament. Medium hardy ; fast grower.

Coprosma LUCidA-Karamu.-New Zealaud. $6 \mathrm{ft}$. to $15 \mathrm{ft}$. E. Shining green leaves; compact growth; large orange berries; good specımen shrub. Hardy; does weli in poorest soil.

Coprosua robusta - Kakaraumu. - New Zealand. $8 \mathrm{ft}$. to $12 \mathrm{ft.} \mathrm{E.} \mathrm{Fast-}$ growing; erect branches; shelter and ornament. Hardy; any soil if not wet.

Coprosma BAUERI-Naupata, or Taupata.-Northern New Zealand. $10 \mathrm{ft}$. to $20 \mathrm{ft}$. E. Excellent, glossy-leaved, and fast-growing; splendid hedge-plant. Northern districts only, near the sea.

Cerasus serrulata (C. Sieboldtil)-Flowering-cherry.-China. $15 \mathrm{ft}$. to $20 \mathrm{ft}$. D. Bea'xtiful flowering-tree, ornamental only. Hardy; any porous soil.

Crtptomeria japonica, var. elegans (C. veitchir)-Elegant Japanese Cedar. -Japan. $60 \mathrm{ft}$. E. Beautiful feathery foliage, turns red in winter; ornamental ard shelter. Hardy; any soil and exposure.

Cryptomeria japonica (Taxodium japonicum)-Common Japanese Cedar.Japan. $100 \mathrm{ft}$. E. Attains buge circumference. Very valuable timber. Prefers moist ground, free from cold winds.

CUPREss Us MACrocarpa (C. LAMBERTIANA)-Monterey Cypress.-South Californian coast. $50 \mathrm{ft}$. to $70 \mathrm{ft}$. E. Well-known shelter-tree; shelter and hedge-screens. Short-lived, except on deep soil near the coast. 


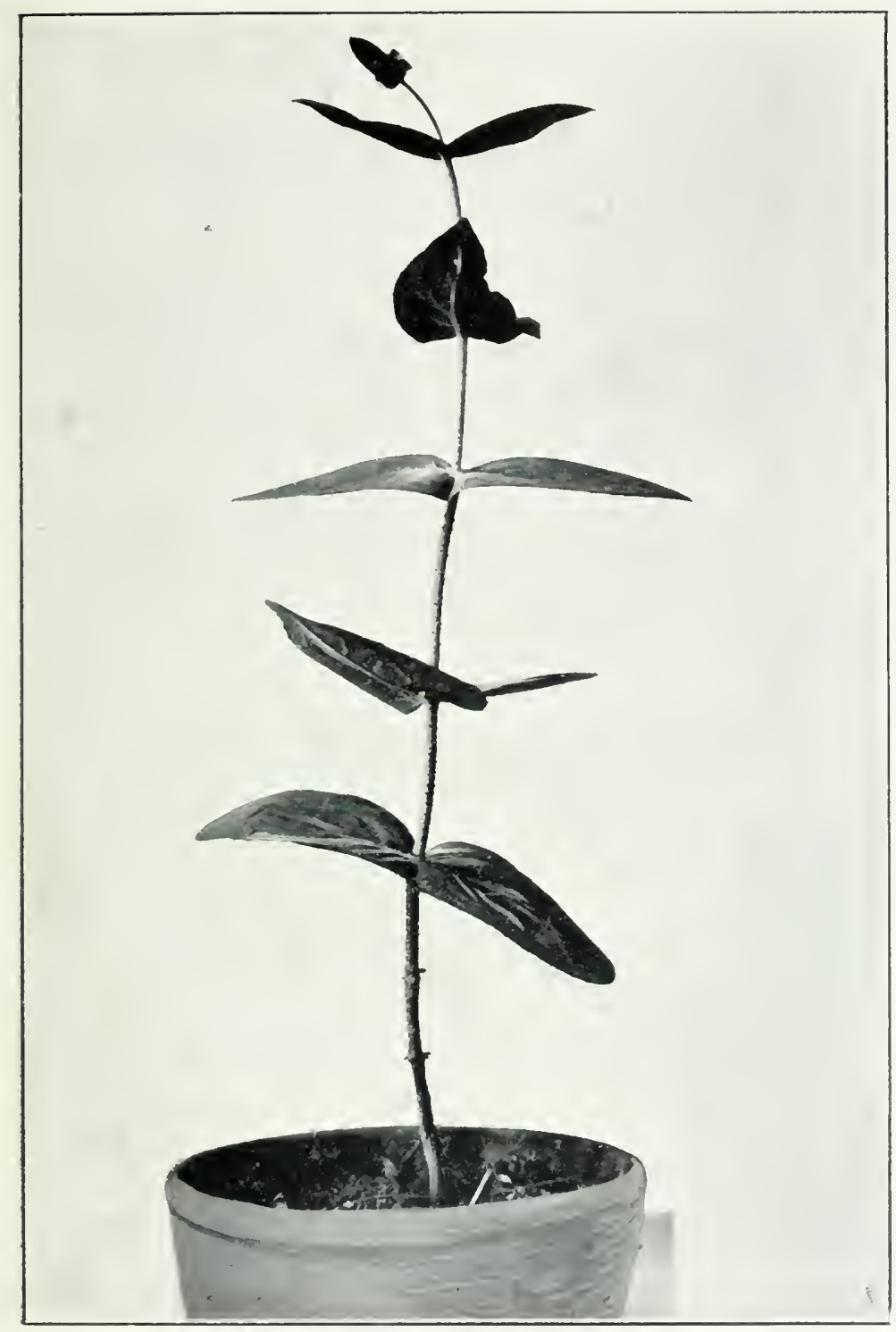

EUCALYPTUS RECXIXS SEEDLING, SIX MOXTHS OLD.

Plate 53.J

[Face p. 106. 

Cupressus goveniana (C. Californica)-Goven's Cyprese.-South Californian coast. $20 \mathrm{ft}$. E. Beautiful ornamental Cypress; shelter and hedgescreens. Hardy; succeeds in any soil or situation.

Cupressus sempervirens (C. Fastigata)-Roman Cypress.-South Europo. $60 \mathrm{ft}$. to $100 \mathrm{ft}$. E. Upright habit; sombre green; ornamental, and imperishable timber. Does best on limestone; attains great age.

Cupressus torulosa (C. Nepaulensis) - Tufted Cypress. - North India. $40 \mathrm{ft}$. to $100 \mathrm{ft}$. E. Very ornamental ; light-green foliage; shelter, ornament, and timber. Does best at some elevation ; hardy ; any soil.

Cupressus funebris - Funeral Cypress.-Thibet. $90 \mathrm{ft}$. E. Dense growth ; foliage changes with age; shelter and ornament. Hardy; medium soils, high elevations.

Dacryiem biforme (D. Colensoi)-Yellow Pine; Tar-wood.-New Zealand. $20 \mathrm{ft}$. to $40 \mathrm{ft}$. E. Remarkable dimorpbic foliage; slow growth; orna. mental. Valnable timber. Hardy; high elevations.

DAcrydidm Kirkit-Manoao. - Northern New Zealand. $40 \mathrm{ft}$. to $60 \mathrm{ft}$. E. Handsome pyramidal tree. Extremely valuable timber; ornamental. Northern New Zealand only.

Dacrydum istermedium-Yellow Silver-pine.-New Zealand. $10 \mathrm{ft}$. to $50 \mathrm{ft}$. E. Conical growth, spreading with age. Very durable timber. Hardy in Dunedin; does best in moist soils.

Dacridium colexsoi (D. Westuandicum). - Westland or Silver Pine--New Zealand. $60 \mathrm{ft}$. to $80 \mathrm{ft}$. E. Tapering habit; slow growth. Tough, elastic, and durable timber. Deep moist soil, and sheltered situations.

Dacrydiun cupressinum-Rimu, or Red-pine.-New Zealand. $60 \mathrm{ft}$. to $80 \mathrm{ft}$. E. The most graceful of New Zealand trees. Ornamental, well-known timber. Aay soil; requires dense shade when young to succeed well.

Dodones viscosa-Akeake.-New Zealand, Anstralia, Africa, Asia, \&c. $20 \mathrm{ft}$. to $30 \mathrm{ft}$. E. Papery brown bark; light.green foliage; ornamental and shelter; heavy dense timber. Half-hardy; any soil.

Drsoxylum SPECTABILE-Kohekohe.-Northern portions of New Zealand. $30 \mathrm{ft}$. to $50 \mathrm{ft}$. E. Round-headed tree; pendulous flowers. Durable tim. ber in sandy soils; ornamental. North Island only; deep soil.

Drims axillaris (Wintera axillaris) - Horopito, Pepper-tree,-riorthern portions of New Zealand. $30 \mathrm{ft}$. E. Dense habit; dull-green foliage; ornamental only. Any soil ; bardy.

Drisys colorato-Horopito, Pepper treę.-Southernesew Zealand. $20 \mathrm{ft}$. E. Compact growth; bright.red foliage; very ornamental. Any soil; hardy.

Elaocarpus dentatus-Hinau.-Northern New Zealand. $40 \mathrm{ft}$. to $60 \mathrm{ft}$. E. Much-branched, round-headed tree; ornamental; slow grower. Northern districts only; ordinary soil.

Elmocarpus Hookeriaxus-Pokaka.-New Zealand. $50 \mathrm{ft}$. E. In young staie tortuous and interlaced, afterwards upright growth; ornamental ; slow grower. Tender when young; sheltered situations.

Extrlea ARborescens-Whau, Cork-wood.-Northern New Zealand. $25 \mathrm{ft}$. E. Handsome erect shrub, large leaves and flowers; ornamental; fast grower. Tender; requires shelter; northern coastal districts only.

Etgenia MAIRE-Maire-tawhake.-Northern New Zealand. $20 \mathrm{ft}$. to $50 \mathrm{ft}$. E. Conical growth; white flowers, large red fruit; ornamental; valuable timber. Swampy lands, northern districts.

EUCALYPTUS AMYGdaLINa-Almond-leaved Peppermint Gum.-Victoria, New South Wales, Tasmania. $100 \mathrm{ft}$. to $300 \mathrm{ft}$. E. One of the largest of the Eucalypti. Foliage for extraction of oil, timber for inner building-material. Hardy; does best in sheltered valleys. 
EUCALYPTUS CREBRA-Narrow-leaved Ironbark. - New South Wales and Queens. land. $100 \mathrm{ft}$. E. Fast grower. Very valuable timber, strong and durable. Half-hardy; good soils, northern coasts only.

Eucaliptus Capitellata-Head-flowered Stringy-bark.-New South Wales and Gippsland. $100 \mathrm{ft}$. to $200 \mathrm{ft}$. E. One of the Stringy-barks; fast grower. Timber for rough carpentry, not durable under ground. Medium hardy; wet sandy lands.

Eucalyptus coccifera--Mountain Peppermint.-Alpine districts of Tasmania. $80 \mathrm{ft}$. E. Handsome upright grower. Produces good general buildingtimber. Exceedingly hardy ; any soil or situation.

Eucalyptes maculata - Spotted Gum. - New South Wales, Queensland. $150 \mathrm{ft}$. E. Medium fast grower; straight stems. Produces the best timber for coauhbuilders' work. Very tender; stony ridges, North of Auckland only.

Eucalyptus obliqua-Stringy-bark, or Messmate Gum.-New South Wales, Victoria, Tasmania. $100 \mathrm{ft}$. to $300 \mathrm{ft}$. E. Attains immense diameter. Produces excellent timber on poor soils. Mountainous country; tap-roots descend to great depths; hardy.

Eucalyptus padciflora (E. Coriacea) - White or Drooping Gum.-New South Wales, Victorie, and Tasmania. $80 \mathrm{ft}$. to $100 \mathrm{ft}$. E. Smooth white bark, drooping foliage. Ordinary building, fencing, firewood. Hardiest Eucalyp. tus known; does best in moist soils.

Eucalyptus pilularis-Blackbutt.-New South Wales, Queensland, Gipps. land. $100 \mathrm{ft}$. to $300 \mathrm{ft}$. E. Rapid growth, rather branching. Flooring, railway-sleepers, and posts. Half-hardy; northern coasts only; good loamy soil.

Eucalyptus Pipenita-Peppermint Gum, or White Stringy-bark.-New South Wales, Victoria. $100 \mathrm{ft}$. E. Medium growth; leaves very inflammable. Rough carpentry and fencing. Half-hardy ; medium soils.

Eucalyptus polynanthema-Red Box-gum.- South-eastern Australia. $150 \mathrm{ft}$. to $250 \mathrm{ft}$. E. Rapid grower in good soil. Durable timber for wheelwrights' work, sleepers, and posts. Half-hardy; any soil if not wet.

Eucalyptus Goxiocalyx (E. ELmophora)-Spotted Gum, \&c.-Victoria and New South Wales. $80 \mathrm{ft}$. to $300 \mathrm{ft}$. E. Fairly good growth. Wheelwrights' work, fencing, and fuel. Medium hardy, gravelly hillsides.

Eucalyptus LeUCOXYlon (E. Sideroxylon)-Victorian Red-ironbark. - South Australia. $100 \mathrm{ft}$. to $200 \mathrm{ft}$. E. Fast grower in moist warm situations. Strongest and most durable of all the eucalypti. Tender, only fit fur Auckland coastal districts.

EUCALYPTUS IACRORHYNCHA-Stringy-bark of Victoria.-Victoria anã New South Wales. $80 \mathrm{ft}$. to $120 \mathrm{ft}$. E. Very tall tree. Strong timber for all general purposes. Half-hardy; sterile ranges and ridges.

Eucaliptus Resinifera-Red or Forest Mahogany.-New South Wales, Queensland. $80 \mathrm{ft}$. to $100 \mathrm{ft}$. E. Large tree, rapid growth. Timber durable and of great strength. Half-hardy; requires good soil ; coastal dis. tricts, northern portions only.

Eucaliptus Calophylla-Red-gum.-South-western Australia. $60 \mathrm{ft}$. to $80 \mathrm{ft}$. E. Umbrageous tree, rapid growth, very ornamental. Spokes and agricultural purposes, not durable under ground.

Eucalyptus viminalis-Manna.gum.-Victoria, New South Wales, Tasmania, \&c. $100 \mathrm{ft}$. to $320 \mathrm{ft}$. E. White silvery bark, leaves resemble the willow. Strong and fairly durable timber, much resembling Ash. Half-hardy; does best on rich soil.

Eucalyptes TereticonNis-Red-gum of Queensland.-New South Wales, Gippsland. $100 \mathrm{ft}$. to $160 \mathrm{ft}$. E. Fast-growing-has grown $60 \mathrm{ft}$. in seven years. Durable timber for naves, felloes, and wheels. Half-hardy; will succeed in any soll or situation if not too frosty. 


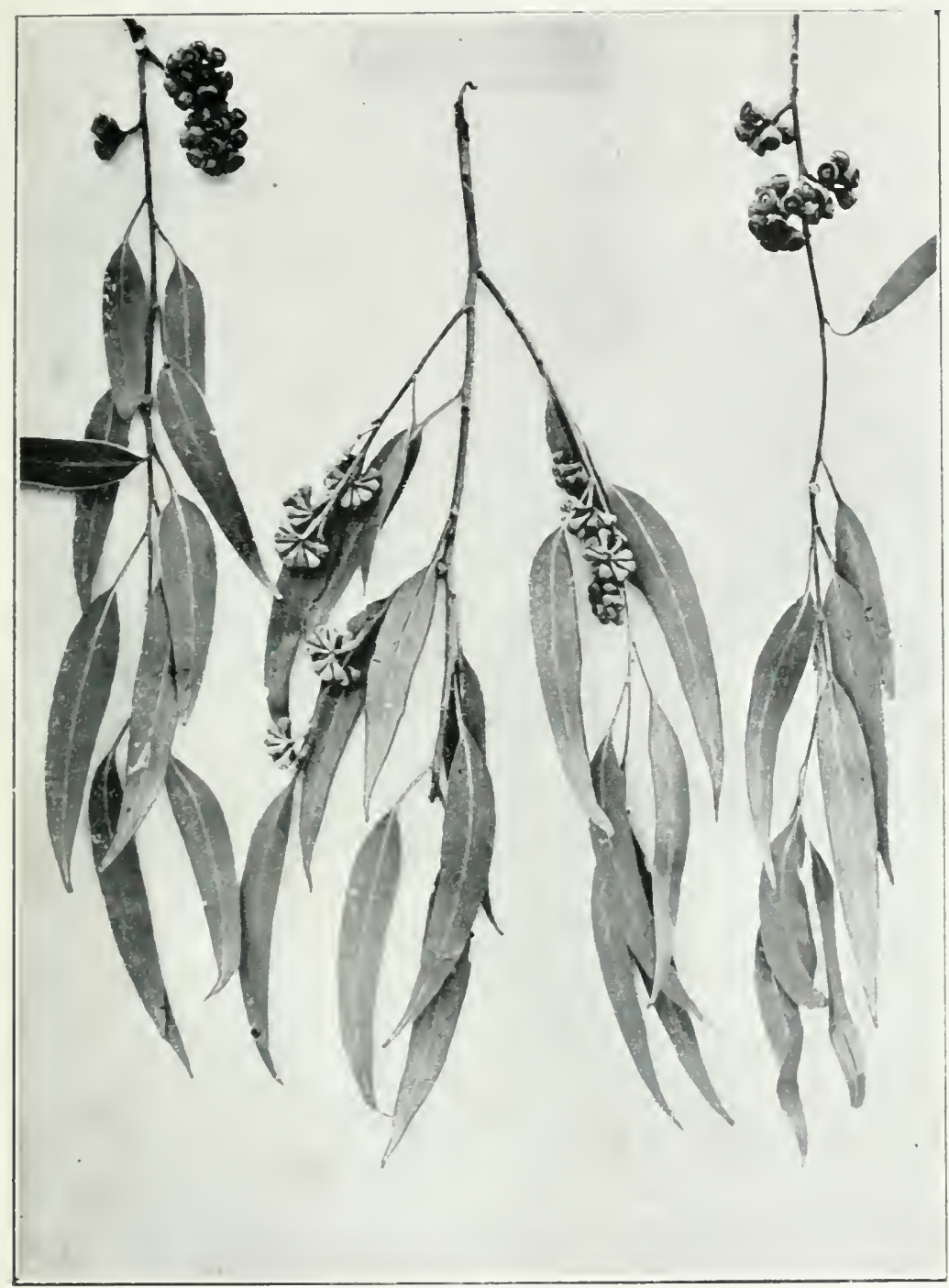

FUCAIYTT'S REGNANS, MATUE FOIIAGE, RIPE AND HALF-RIPENED CAPSULES, ONE-HALF NATURAL SIZE.

I'late 54.]

[Face p. 108 . 

Eucalyptes Globules-Blue-gum.-Victoria, Tasmania. $150 \mathrm{ft}$. to $300 \mathrm{ft}$. E. Well-known tree. Timber very durable from aged trees grown on gravelly or poor soil. Medium hardy; coastal districts in the south.

Eucalyptes ficifolia - Scarlet-flowering Gum. - South-western Australia. $50 \mathrm{ft}$. E. Magnificent trusses of bloom; ornamental value only. Medium hardy; dry sandy soils.

Eucalrptus Robusta-Swamp Mahogany.-New South Wales and South Queensland. $100 \mathrm{ft}$. E. Large handsome tree; shade and ornament. Durable timber for wheelwrights. Half-hardy; low, sour, swampy lands near the coast.

Eucalyptes sargixata-Jarrah. - South-western Australia. $100 \mathrm{ft}$. to $150 \mathrm{ft}$. E. Comparatirely slow growth. Famed for its indestructible timber. Tender; does best on ironstone, nortberu Auckland only.

Eucatrptes gomphocephala-Tooart.-South-western Australia. $120 \mathrm{ft}$. E. Beautiful straight boles. One of the strongest timbers known-bridges and beams. Half-hardy; does best on limestone.

Eucalyptus sieberiana (E. Virgata)-Yowut, Mountain Ash, or Tasmanien Ironbark).- South-eastern Australia and Tasmania. $100 \mathrm{ft}$. to $150 \mathrm{ft}$. E. Straight-stemmed, fast grower. Strong and elastic timber-posts, sleepers, fc. Will succeed in most situations; hardy.

EUCALYPTS's MUELLERI - Mountain Red-gum.-Mountains of Tasmania. $150 \mathrm{ft}$. E. Erect massive bole. General building-timber. Tery hardy; any soil and situation.

Eccalrptes Microcorrs- Wangee, Stringy-bark, Tallow-wood, \&c.-New South Wales and South Queensland. $150 \mathrm{ft}$. to $300 \mathrm{ft}$. E. Attains a great size. Valuable timber for floors and decking. Half-hardy; coastal situations North Island only.

Eucalyptes melliodora-Yellow-box.-Victoria, New South Wales. $200 \mathrm{ft}$. to $250 \mathrm{ft}$. E. Spreading habit of growth; good shade-tree. Timber for fencing and fuel. Medium hardy; northern districts only.

Eccalyptes corracalyX-Sugar-gum. - North-western and South-eastern Australia. $100 \mathrm{ft}$. to $120 \mathrm{ft}$. E. Grows $7 \mathrm{ft}$. to $8 \mathrm{ft}$. annually in warm moist situations. Wood hard and durable, dense and strong; posts and sleepers. Half-hardy; humid soils, northern districts.

Eccalyptes hemiphloiA (E. ALBExs)-White-boz.-South-eastern Australia (inland). $100 \mathrm{ft}$. to $180 \mathrm{ft}$. E. Tree of striking appearance. Hard, tough, durable timber; spokes, felloes, and sleepers. Medium hardy; coastal districts, free open soil.

Eccalyptes hemostoma-Gum-topped Stringy-bark.-Tasmania, Victoria. $100 \mathrm{ft}$. to $150 \mathrm{ft}$. E. Tall sparingly branched tree. Timber only fit for fuel and rough carpentry, not durable. Hardy; hilly country, poor soils.

Eccalyptes Regraxs (E. GIGartea)-Giant or Swamp Gum of Tasmania.Tasmania and Victoria. $100 \mathrm{ft}$. to $471 \mathrm{ft}$. E. The tallest tree known; fast-growing. Very strong timber, but not durable in contact with the ground. Hardy; almost any soil or situation if sheltered.

EdCALYptus Paxiculata (E. Fascictlosa)-Red-ironbark, \&c. - New South Wales and South-western Australia. $100 \mathrm{ft}$. to $140 \mathrm{ft}$. E. Very handsome tree. One of the most durable of the Ironbarks for piles and girders. Halfhardy; northern coastal districts only.

Eucalyptus difersicolor (E. colossea) - Karri. - South-western Australia. $300 \mathrm{ft}$. to $400 \mathrm{ft}$. E. Colossal tree; clear bole. Valuable timber for shafts, spokes, felloes, \&c. Half-hardy ; fertile humid valleys.

Eucalyptus GuxiI - Cider-gum. - Victoria, New South IVales, Tasmania. $200 \mathrm{ft}$. to $250 \mathrm{ft}$. E. Pather branching growth, the best for shelter. Supplies strong useful timber for farm purposes, posts, \&c. Hardy; any soil or situation. 
Eucalyptus stuartiana-Apple-scented Gum, Tasmanian Red-gum.-Southeastern Australia and Tasmania. $80 \mathrm{ft}$. to $100 \mathrm{ft}$. E. Medium size, fibrous bark, and drooping branches; fast-growing. Excellent fuel; strong and durable timber. Hardy; grows on dry, sandy, or bumid soils.

Eucalyptus rostrata-Red-gum.- South and inland Australia. $200 \mathrm{ft}$. E. Usually of spreading habit; subject to insects eating leaves. Heavy, hard, strong, and àrable tımber. Half-hardy, moist ground with clayey subsoil, northern districts.

Eucalyptus SIDERophloia (E. PERsicifolia) - Red-ironbark. - New South Wales, South Queensland. $100 \mathrm{ft}$. to $150 \mathrm{ft}$. E. Rather slow growth. Another durable ironbark; wheelwrights, piles, and sleepers. Half-bardy, nortbern coasts only.

Eucalyptus URNigera-Urn-bearing Gum.-Tasmania. $50 \mathrm{ft}$. to $70 \mathrm{ft}$. E. Tall erect tree, smooth bark. Supplies durable timber for all farm purposes. Exceedingly bardy, does well in any situation.

Fagus sylyatica-English Beech.-Europe. $60 \mathrm{ft}$. to $80 \mathrm{ft}$. D. Well-known tree of Europe. Timber for chairs, tools, and firewood. Hardy ; does best on chalky or limestone lands.

FAGUS FERRUGiNed-North American Beech.-North America. $100 \mathrm{ft}$. D. Large-growing tree; quick growth. Timber for implements, turning, \&o. Hardy; rocky soils, exposed situations.

FAgus Fusca-Red Beech or Birch-Tawhai-ran-nui.-Nẹw Zealand. $80 \mathrm{ft}$. to $100 \mathrm{ft}$. E. Noble tree, fast-growing. Timber red, tough, straight-grained, and strong. Hardy; any soil, sheltered situations.

FAgus solandri-Red, Black, White, or Brown Birch-Tawhai.-New Zealand. $60 \mathrm{ft}$. to $80 \mathrm{ft}$. E. Fine spreading-branched evergreen. Heartwood dark, last. ing in the ground if grown on dry soils. Hardy ; prefers elevation, any soll.

FAgus Menziesil-Silver Beech or Birch-Tawhai.-New Zealand. $60 \mathrm{ft}$. to $100 \mathrm{ft}$. E. Symmetrical habit, silvery bark. Deep-red timber, evengrained, tough and elastic. Hardy ; inland distriets, äry open soil.

Fagus Blairil-Blair's Beech.-New Zealand. $50 \mathrm{ft}$. to $80 \mathrm{ft}$. E. Handsome tree, resembling English Beech. Timber resembles above. Hardy; inland districts, dry open soil.

FAgUS CLIFFortioldes-Mountain-beech, White-birch, Black-birch.-New Zealand. $40 \mathrm{ft}$. to $50 \mathrm{ft}$. E. Perbaps the most ornamental of all the species. Timber resembles above. Hardy ; inland districts, dry open soil.

Ficus macrophylla-Moreton Bay Fig.--New South Wales and Queensland. $100 \mathrm{ft}$. E. The best of Australian avenue-trees. Chiefly ornamental and shade. Half-hardy; good rich soil, northern coasts only.

Fraxinus Excelsior-English Ash.-Europe, A via. $100 \mathrm{ft}$. D. Tree of quick growth. Timber tough and elastic, used for carriage-work, \&c. Hardy; deep soil on river-banks and ravines suits it best.

Fraxinus anericana-White-ash.-Canada, Florida. $100 \mathrm{ft}$. D. Best and quickest-growing of American Ashes. Tough, elastic, and light timber. Hardy; deep humid soils.

Fraxinus Quadrangulata-Blue-ash.-North America. $70 \mathrm{ft}$. D. Tall and straight-growing. Timber the most durable of the Ashes, used for carriagework, \&c. Harcy; mild climates, fertile soils.

Fraxinus lanceolata (F. viridis) - Green-ash. - Eastern North America. $70 \mathrm{ft}$. D. Fast.growing; good shade-tree. Excellent timber for bentwork. Hardy; does best in heavy soils.

Fraxinus nigra (S. SAmibuscifolia) -- Black-ash.-Eastern North America. $80 \mathrm{ft}$. D. Fast-growing tree. Timber tough and elastic, used for oars and wagon-work. Hardy ; deep, loose, moist soils, sheltered situations.

Fraxinus Pennsylvanica (F. Pubescens)-Red-ash.-North Atlantic States. $60 \mathrm{ft}$. D. Medium-sized tree, upright growth. Timber used for coach. builders' work. Hardy ; heavy soils, sheitered situations. 


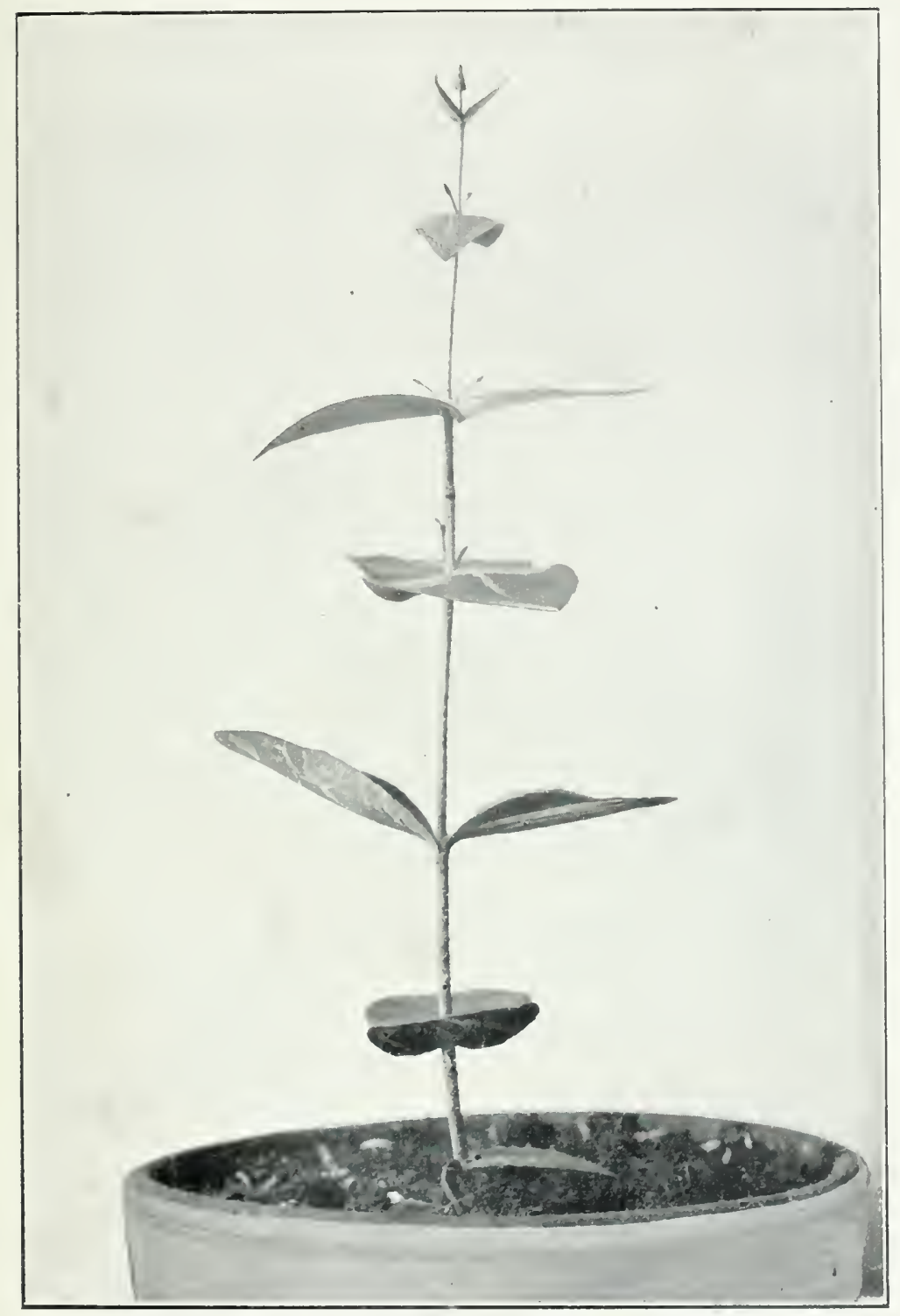

EUCALYPTIS STIARTIANA SEEDLING, SIX MONTHS OLD.

Plate 55.]

[Face p. 110. 

Fraxisu's oregaxa-Oregon Ash.-Washington to California. $70 \mathrm{ft}$. D. Low, spreading tree. Timber used for coachbuilders' work. Hardy; heavy soils, sheltered situations.

Griselixia littoralis - Broadleaf, Papauma. - New Zealand. $60 \mathrm{ft.} \mathrm{E.}$ Well-known native tree; shelter and hedges. Lasting timber for posts, \&c. Hardy ; any soil and situation.

Griselixia Lucida - Puka. - North New Zealand. $30 \mathrm{ft}$. E. Large glossy green leaves. Ornamental only. Half-hardy; northorn coastal districts.

Gleditschia tricanthos (Gleditsia tricanthos) - Honey-locuzt. - Southeastern North America. $50 \mathrm{ft}$. to $80 \mathrm{ft}$. D. Quick-growing; thorny. Hard, close-grained timber for posts, \&c. Hardy ; any soil.

Giskgo BILOBA (SALISBuria adiantifolia)-Ginkgo-tree.-China and Japan. $100 \mathrm{ft}$. D. Straight-stemmed fan-leaved tree. Soft, pale timber, used for furniture. Harảy; does well in pumice soil.

Grevillea Robusta-Silky Oak,-New South Wales and Queensland. 80 ft. to 100 ft. E. Beautiful fern-like foliage; chiefly ornamental. Timber used for cabinetwork. Half-hardy ; any open free soil, sheltered.

Granoclades dioicus (G. Canadensis)-Coffee-tree.-North-eastern America. Soft. D. Handsome arenue-tree. Timber strong, tough, and fine-grained. Hardy ; rich soil, sheltered positions.

Gaya lyalit (Plagianthus Lyallin)-West Coast Ribbonwood, or Lacebark. -New Zealand. $20 \mathrm{ft}$. D. One of our best native flowering-trees; ornamental only. Hardy; does well in any soil ; requires shelter.

Hedycarya arborea (Hedycarya dentata)--Porokaiwhiri.-New Zealand. $40 \mathrm{ft}$. to $50 \mathrm{ft}$. E. Handsome tree of striking appearance. Ornamental; produces large rea berries. Half hardy; free soil, northern districts only.

Hoheria populnea-Houhere, Ribbonwood.-New Zealand. $30 \mathrm{ft}$. to $50 \mathrm{ft}$. D. or E. Exceedingly variable fcliage; ornamental; handsome white flower. Hardy ; does best on river banks.

ILEX AQUIFOLIA-English Holly.-Europe, Western Asia. $60 \mathrm{ft.}$ E. Wellknown tree or shrub; ornamental and hedges. Timber pure white. Hardy; does best on heavy clay lands in cold localities.

ILEX OPACA-American Holly.-United States. $30 \mathrm{ft}$. to $40 \mathrm{ft}$. E. Much resembling above; ornamental and bedges. Hardy; gravelly and atony soils.

IXERBA BRExioides-Tawari.-Northern New Zealand. $70 \mathrm{ft}$. E. Elegant flowers and foliage; ornamental. Half-hardy; open forest lands.

Jcglaxs Regia-Walnut. - Europe, Asia. $100 \mathrm{ft}$. D. Well-known tree; edible nuts. Timber light and tough for furniture, \&c. Hardy; prefers calcareous soils.

Jeglaxs sigra-Black-walnut.-Eastern North America. $75 \mathrm{ft}$. to $100 \mathrm{ft}$. D. Faster-growing than above. Chief furniture timber used in America; compact and durable. Hardy; rich forest lands, sbeltered.

Juglass cinerea - Butternut. - Eastern North America. $40 \mathrm{ft}$. D. Very handsome tree; quick growth. Light timber; durable in ground and free from insect attacks. Hardy, even in St. Petersburgh; rocky soils.

Juglaxs CALIFORNICA-Californian Walnut. - California. $75 \mathrm{ft}$. D. Sym. metrical tree. Useful timber for cabinetwork. Hardy; does best on riverbanks.

Juniperus bermudiana (J. Fragrans)-Pencil-cedar of Bermuda.-Bermuda. $90 \mathrm{ft}$. to $100 \mathrm{ft}$. E. Erect-growing tree. Red durable wood, chiefly used for pencils and furniture. Hardy ; does well on the poorest soils.

Juxiperús Chinessis (J. JAPONiCA)-Indian Pencil-cedar.-Himalayas, China. $100 \mathrm{ft}$. E. Largest growing of the Junipers. Red, fine-grained timber. Hardy; any ordinary soil ; stands exposure. 
Juniperus Virginiana (J. Barbadensis) - American Red-cedar. - North America. $90 \mathrm{ft}$. E. Handsome erect tree. Furnishes exceedingly durable timber. Hardy; does best near the coast, dry sandy soil.

Juniperus occidentalis-Western Juniper.-Western Pacific. $60 \mathrm{ft}$. to $80 \mathrm{ft}$. E. Straight-growing and compact. Pale, close-grained timber. Hardy; rocky soils, dry situations.

Juniperus excelsa-Tall Crimean Juniper.-Asia Minor. $90 \mathrm{ft}$. E. Stately tree, immense girth. Produces durable light timber. Hardy; elevated dry situations.

KNightia Excelsa-Rewarewa, or Honeysuckle.-Northern New Zealand. $70 \mathrm{ft}$. to $100 \mathrm{ft}$. E. Elegant erect-growing tree; ornamental. Timber finely figured, used for furniture. Half-hardy; any ordinary soil.

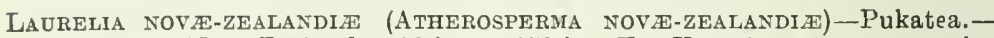
Northern New Zealand. $90 \mathrm{ft}$. to $150 \mathrm{ft}$. F. Very large tree; massive trunk; ornamental. Timber pale brown; does not split; strong fibre ; not durable in contact with the ground. Half-hardy; swampy or moist gullies, North Island only.

LEPTOSPERAIUM ERICOIDES-Manuka-rauriki, or Red-manuka.--New Zealand. $40 \mathrm{ft}$. to $60 \mathrm{ft}$. E. Well-known tree. Timber hard, not durable. Hardy; does well in the poorest as well as the richest land.

LeptosPermum SCOPARIUM - Manuka. - New Zealand, $15 \mathrm{ft}$. to $30 \mathrm{ft}$. E. Well-known tree; very ornamental when young. Hardy; does well on the poorest as well as richest land.

Libocedrus doniana (Thuja doniana)-Kawaka, Native Cedar.-Northern New Zealand. $80 \mathrm{ft}$. to $100 \mathrm{ft}$. E. Fine conical growth; ornamental. Dark-red timber; durable. Hardy; any ordinary soil.

Libocedrus BidwilliI-Pabautea, Native Cedar.-New Zealand. $50 \mathrm{ft}$. to $80 \mathrm{ft}$. E. Tapering, cone-shaped. Timber resembles Redwood; durable, though soft. Hardy; prefers elevated moist situations.

Libocedrus decurrens (ThuJa cragiana) - Incense, or White-cedar. - California. $200 \mathrm{ft}$. E. Upright growth; ornamental. Light, yet strong timber, used for cabinetwork.

Laburnom velgare (Cytisus laburnum)-Laburnum.-Europe. $20 \mathrm{ft}$. D. Well-known tree; hairy seed-pods; ornamental. Produces exceedingly hard timber. Hardy; any soil or situation.

LABURNOM ALPINUM (CrTisUS ALPINUM)-Scots Laburnum.-Europe. $20 \mathrm{ft}$. D. Similar to above, but later flowering; ornamental. Produces exceedingly hard timber. Hardy; any soil or situation.

Litsca Calicaris (Tetranthera Calacaris)-Mangeao.-Northern New Zealand. $30 \mathrm{ft}$. to $40 \mathrm{ft}$. E. Erect-growing evergreen; ornamental. Timber used for shafts, bent-work, \&c. Half-bardy ; northern districts only.

LaUris NobILIS - Sweet-bay. - Southern Europe, Asia Minor. $60 \mathrm{ft.} \mathrm{E.}$ Excellent hedge-plant; ornamental and shelter. Hardy; heavy soils.

LeUCADENDRON ARGENTEUM-Silver-tree.-South Africa. $20 \mathrm{ft}$. to $30 \mathrm{ft}$. E. Magnificent specimen-tree; ornamental; splendid specimen-plant. Halfbardy ; free open soils.

Liriodendron tulipifera-Tulip-tree, Bassnood, de.-United States.-140 ft. E. Very ornamental tree; fine for avenues. Light-yellow timber, free of knots, easily worked. Hardy; deep, dry, loamy soils, sheltered.

LARIX EUROP Ea (PiNUS LARIX)-European Laroh.-Europe. $80 \mathrm{ft}$. to $100 \mathrm{ft}$. D. Perbaps the most useful timber-tree for New Zealand. Timber of great durability, fast-growing, easily worked; the best timber for posts. Hardy ; cool climates, southern aspects, somewhat elevated dry soils.

Larix laricina (L. Americana, L. PENdula) - Tamarack. - North America. $50 \mathrm{ft}$. to $70 \mathrm{ft}$. D. Pyramidal growth. Very durable timber. Hardy; moist swampy lands. 


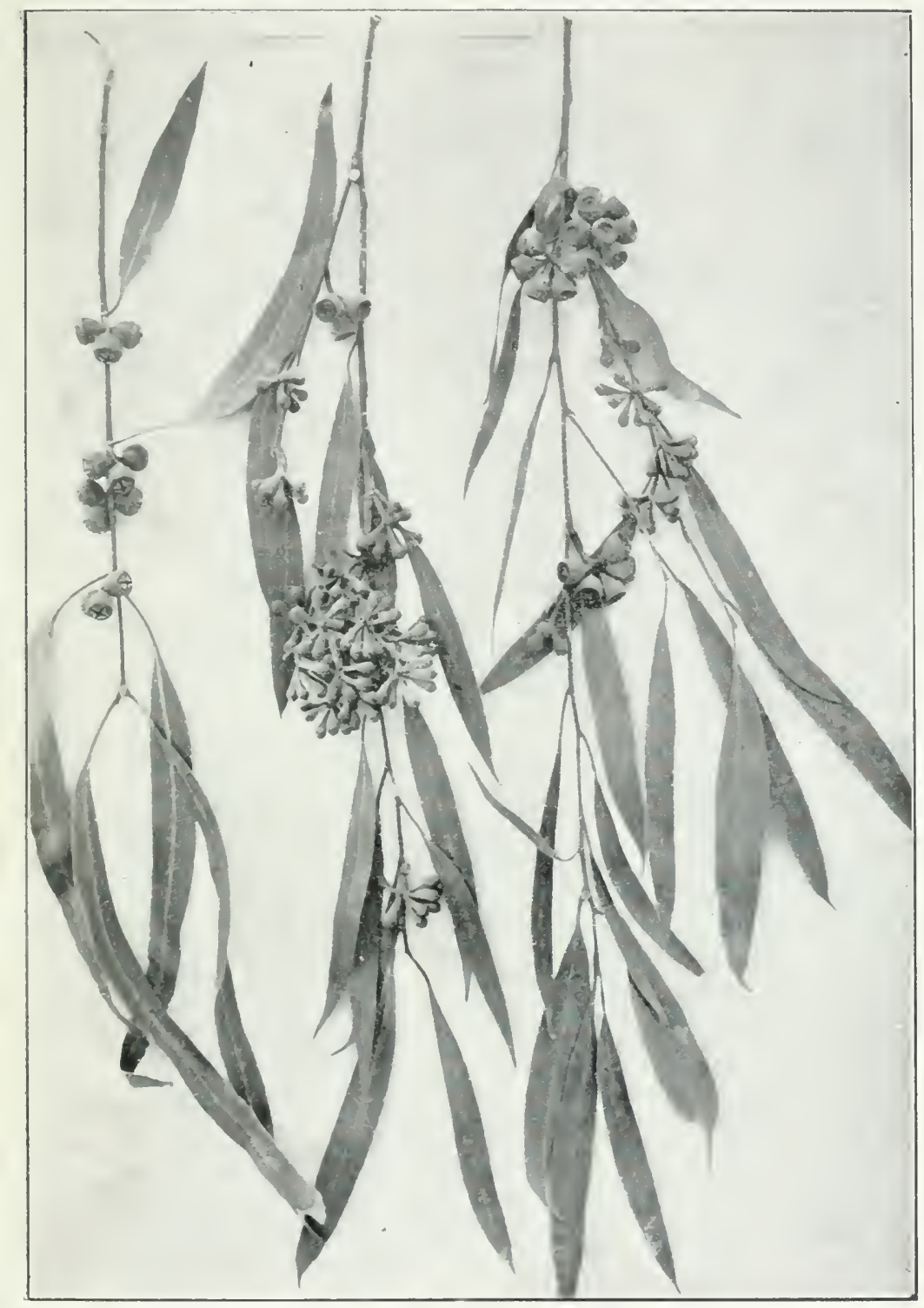

EICALYPTLS STUARTINI, MATIRE FOIIAGE, RIPË CAPSILES IND FLOWERHCDS, OXE-HALF NATLPAL SIZ. Plate 56.]

[Frece p. 112 . 

Larix occidentalis (Pinus nUtTallit)-Tamarack, Western Larch.-British Columbia. $100 \mathrm{ft}$. to $150 \mathrm{ft}$. D. Graceful straight-stemmed tree. Very durable timber. Hardy; cool dry mountain-slopes.

LARIX LEPTOLEPIS-Japanese Larch.-Japan. $70 \mathrm{ft}$. D. Handsome tree ; reddish branches. Heavy timber, lasting in the ground. Hardy; cooi dry soils, mountain-slopes.

Magnolia Fetida (M. GRandiflora)-Large-flowered Magnolia.-Southern States. $100 \mathrm{ft}$. E. Large leaves and flowers; chiefly ornamental. Hardy ; any soil if sheltered.

Mefictidus Ramifloros-Mahoe, or Hinehine.-New Zealand. $20 \mathrm{ft}$. to $30 \mathrm{ft}$. E. Well-known native tree; ornamental. Hardy; any soil.

Melicytus Lanceolatus-Narrow-leaved Hinehine.-New Zealand. $12 \mathrm{ft}$. to $20 \mathrm{ft}$. E. Light-green leaves; compact growth; ornamental. Hardy; any soil.

Melicope simplex.-New Zealand. $10 \mathrm{ft}$. to $20 \mathrm{ft}$. E. Pretty shrub or small tree; ornamental. Half-hardy ; northern districts only.

Melicope ternata-Tataka.-New Zealand. $10 \mathrm{ft}$. to $20 \mathrm{ft}$. E. Pretty shrub or small tree; ornamental. Hardy; cool dry soil.

Metrosideros LUCida-Southern or Mountain Rata.-New Zealand. $30 \mathrm{ft}$. to $60 \mathrm{ft}$. E. Large round-headed tree; ornamental, sbelter. Timber heavy and of great strength. Hardy ; any soil or situation if not wet.

Metrosideros robusta-Northern Rata.-New Zealand. $60 \mathrm{ft}$. to $100 \mathrm{ft}$. E. An immense tree, usually beginning life in the fork of another tree; ornamental. Timber excellent firewood; the only New Zealand tree producing timber from aerial roots. Hardy; any soil.

Metrosideros tomentosA-Pohutukawa.-Northern New Zealand. $30 \mathrm{ft}$. to $70 \mathrm{ft}$. E. One of the finest native flowering-trees. Valuable timber; crooked and guarled stems and branches. Half-hardy; northern coasts only.

Mroporum Latum-Ngaio.-New Zealand. $20 \mathrm{ft}$. to $30 \mathrm{ft}$. E. Large spreading beads; shelter principally. Timber used for turning. Hardy; coastal situations, any soil or exposure.

Melia azedarach-Pride of India.-Asia, Australia. $40 \mathrm{ft}$. to $50 \mathrm{ft}$. D. Very fast-growing tree; spreading branches; good avenue-tree. Hardy; does well in the driest and most sterile soils.

Iores RUBRA-Red-mulberry.-North America. $60 \mathrm{ft}$. to $70 \mathrm{ft}$. D. Largest of the Mulberries. Strong, dense timber, exceedingly durable. Hardy; deep rich soil ; likes shade.

MIORUS ALBA (M. MrULtiCAULIS)-White-mulberry.-China, India. $30 \mathrm{ft}$. D. Tree of easy cultivation; chiefly grown for its leaves, on which silkworms are fed. Very hardy ; dry well-drained lands.

Morus NigRA-Black-mulberry.--Italy, Persia. $40 \mathrm{ft}$. to $60 \mathrm{ft}$. D. Wellknown tree; produces valuable fruit. Very hardy; sandy coast ridges or inland.

Morus tartarica-Russian Mulberry.-Russia. $40 \mathrm{ft}$. D. Fast-growing and easily raised; good shelter, fruit, and timber. Very hardy; any dry soil.

Mrrsise salicina (Rapanea salicina)-Toro.-New Zealand. $30 \mathrm{ft}$. to $40 \mathrm{ft}$. E. Leaves on the ends of the branohes, white flowers, red berries; orna. mental; good specimen-tree. Hardy; prefers cool moist soils.

Mrrsine orvillei (Rapanea drfillea)-Mapau.-New Zealand. $20 \mathrm{ft}$. to $30 \mathrm{ft}$. E. Handsome, erect, bushy tree; ornamental and shelter. Hardy; any soil or situation.

Olearia angcstifolia-Tete-a-weka, Daisy-tree.-Bluff, Stewart Island, $6 \mathrm{ft}$. to $20 \mathrm{ft}$. E. Beautiful flowering-shrub; ornamental; excellent shel ter-plant. Hardy; situations near the sea only. 
Olearia avicennifolia-Akeake.-South New Zealand. $6 \mathrm{ft}$. to $20 \mathrm{ft}$. E. Shrub of quick growth; excellent shelter-plant. Hardy; any soil or situation.

Olearia Colensoi-Tupari.-South New Zealand. $10 \mathrm{ft}$. to $15 \mathrm{ft}$. E. Large leathery leaves; good shelter for southern coast lands. Hardy; does best at sea-level.

Olearia excorticata - Fuchsia-barked Olearia. - Northern New Zealand. $10 \mathrm{ft}$. to $15 \mathrm{ft}$. E. Upright growth; ornamental and shelter. Hardy; moist lands.

Olearia FURforacea-Akepiro-North New Zealand. $10 \mathrm{ft}$. to $15 \mathrm{ft}$. E. Busby habit; ornamental and bedges. Hardy; any soil or situation.

Olearia Ilicifolia-Hakeke-Native Holly,-Now Zealand. $6 \mathrm{ft}$. to $12 \mathrm{ft}$. E. Much resembling the Holly; ornamental. Hardy; any soil or situation.

Olearia macrodonta-Native Holly.-New Zealand. $6 \mathrm{ft}$. to $20 \mathrm{ft}$. E. Large, prickly, sage-green leaves; ornamental. Hardy; any soil or situation.

Olearia Nitida-Daisy-tree.-New Zealand. $6 \mathrm{ft}$. to $12 \mathrm{ft}$. E. Quick-growing shrub; ornamental and shelter; pure-white flowers. Hardy; any soil or situation.

Olearia traversil-Akeake.-Chatham Islands. $15 \mathrm{ft}$. to $30 \mathrm{ft}$. E. Very quick growth; ornamental and shelter; excellent hedge-plant. Hardy; only in situations near the sea.

Olearia fosterit (Shawia paniculata) - Ake-raho - Golden-akeake. - New Zealand. $10 \mathrm{ft}$. to $30 \mathrm{ft}$. E. Dense-growing shrub (see plate); ornamental; makes an excellent hedge or shelter shrub. Hardy; any soils or situations; does well near tbe sea.

Olea Montana - Narrow-leaved Maire.-Northern New Zealand. $50 \mathrm{ft}$. to $60 \mathrm{ft}$. E. Handsome bushy-headed tree; ornamental. Half-hardy; northern districts only.

Olea apelata - Broad-leaved Maire. - Northern New Zealand. $20 \mathrm{ft}$. E. Remarkable variation in foliage; ornamental. Half-hardy; northern districts only.

Olea Cunninghami - Black-maire. - Northern New Zealand. $70 \mathrm{ft}$. E. Remarkable variable foliage; ornamental. Timber next to Puriri in strength. Half-hardy; northern distriots only.

Olea lanceolata-White-maire,-Northern New Zealand, $50 \mathrm{ft}$. E. Round. headed tree; white bark; ornamental. Half-hardy; northern districts only.

Lea europea (O. sativa) - European Olive. - South Europe, Asia. $60 \mathrm{ft}$. E. A much-neglected tree, easily grown; ornamental, shelter, and production of fruit for oil. Hardy; does best on limestone.

Panax arboreum-Whauwhaupaku. -New Zealand. $12 \mathrm{ft}$. to $20 \mathrm{ft}$. E. Dense, dark.green foliage; good shelter; ornamental. Hardy; any soil or situation.

Panax colensor.-New Zealand. $6 \mathrm{ft}$, to $15 \mathrm{ft}$. E. Dense, dark-green foliage; good shelter; ornamental. Hardy; any soil or situation.

Panax edgerleyi - Paukawa. - New Zealand. $20 \mathrm{ft}$. to $40 \mathrm{ft}$. E. Glossy, green leaves; very ornamental. Hardy; moist soils; requires shade.

Paxax smplex-Haumakaroa.-New Zealand. $5 \mathrm{ft}$. to $20 \mathrm{ft}$. E. Elegant shrub or small tree; ornamental and shelter. Hardy; any soil; requires shade.

Panax sinclairis, - Northern New Zealand. $15 \mathrm{ft}$. to $25 \mathrm{ft}$. E. Rusty-brown foliage ; ornamental. Hardy; free open soils.

Pomaderris elimptrca-Kumarahou.-Northern New Zealand. $10 \mathrm{ft}$. to $12 \mathrm{ft}$ E. Much-branched tree; ornamental. Hardy; any soil. 


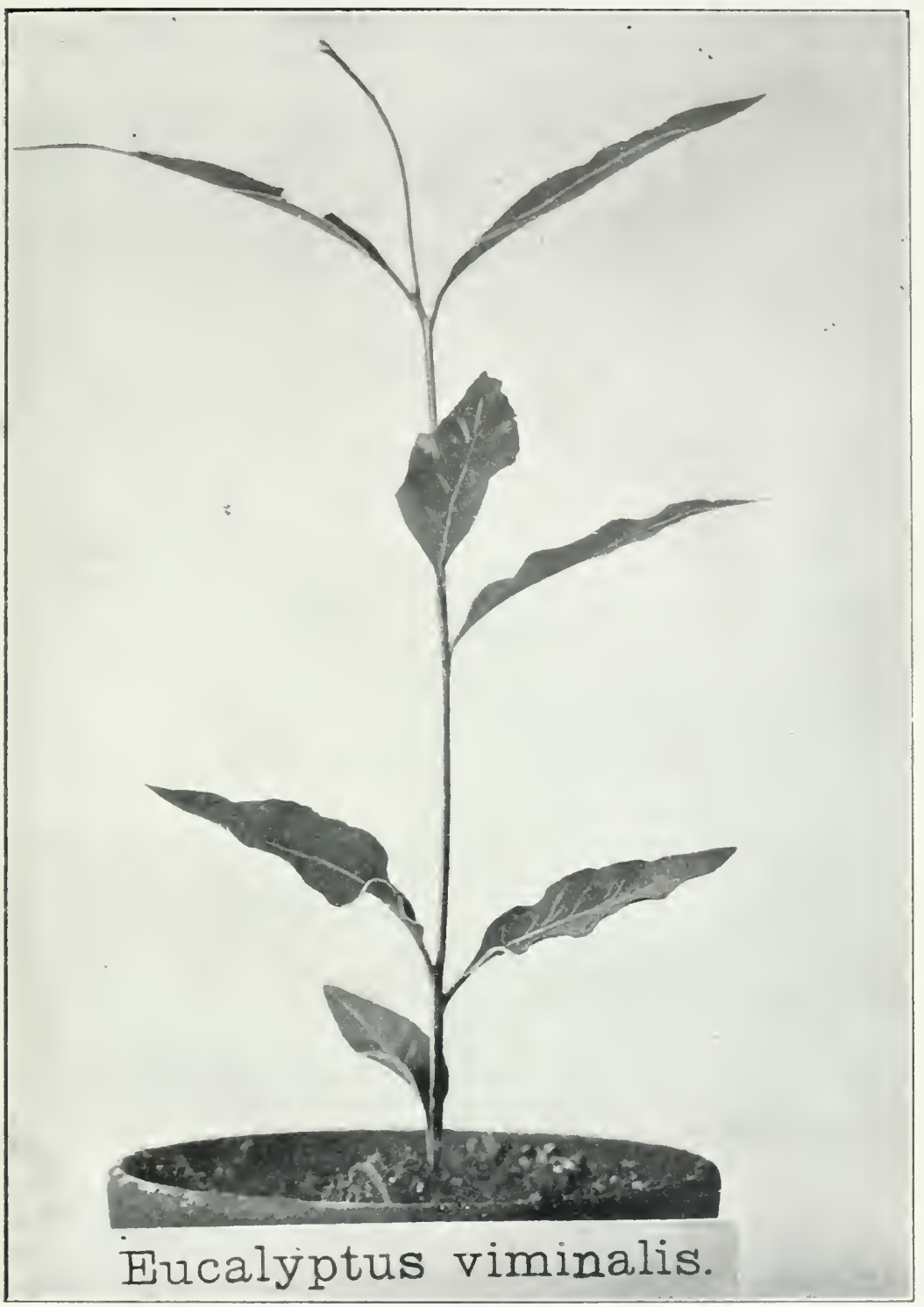

Plate 5\%.]

[Face p. 114. 

Pomaderris apetala-Tainui.-Northern New Zealand. $10 \mathrm{ft}$, to $20 \mathrm{ft}$. E. Very rapid growth; ornamental. Hardy; any soil.

PodOCARPUS DACRYDIOIDES (NAGEIA DACRYDIOIDES)-Kabikatea, White-pine.New Zealand. $100 \mathrm{ft}$. to $150 \mathrm{ft}$. E. Well known timber-tree; ornamental. Timber used for butter-cases, \&c. Hardy; heavy swampy lands.

Podocarpus ferrugineus (Nageia ferrugineus)-Miro, Toromiro.-New Zea. land. $50 \mathrm{ft}$. to $90 \mathrm{ft}$. E. Much resembles English Yew; ornamental. Deep freo loam.

Podocarpus totara (Nageia totara)-Totara.-New Zealand. $80 \mathrm{ft}$. to $100 \mathrm{ft}$. E. Handsome tree; ornamental and sbelter. Produces one of the most valuable timbers known. Hardy; does best in northern districts; any soil if not wet.

Podocarpus halli (Nageia halliI)-Fuchsia-barked Totara.-New Zealand. $40 \mathrm{ft}$. to $60 \mathrm{ft}$. E. Leaves much larger than above; ornamental and shelter. Timber of doubtful value. Hardy; any soil or situation.

Pseudo-panax crassifolium (Panax congissimum)-Horoeka, Lance-wood.New Zealand. $50 \mathrm{ft}$. E. Drooping foliage ; ornamental. Hardy; tertile soils.

Pseddo-panax FErox-Toothed-leaved Lancewood.-New Zealand. $30 \mathrm{ft}$. E. Remarkable toothed-edged leaves; ornamental. Hardy; fertile soils.

Pisonia brunoniana (P. sinclairil)-Parapara.-Northern New Zealand. $40 \mathrm{ft}$. E. Large dark-green leaves; ornamental. Tender; northern coasts only.

Paulowia imperialis.-Japan. $40 \mathrm{ft}$. to $50 \mathrm{ft}$. D. Much resembles Catalpa ; ornamental; a good street or avenue tree; requires shelter. Hardy; deep loam.

Persoonia toru-Toru.-Northern New Zealand. $40 \mathrm{ft}$. to $50 \mathrm{ft}$. E. Worthy of extended cultivation; handsome foliage; ornamental and shelter. Hardy ; any soils and situation.

Pensantia corrmbosa-Kaikomako.-New Zealand. $20 \mathrm{ft}$. to $40 \mathrm{ft}$. E. or D. Bright-green leaves, pure-white flowers; ornamental; deciduous in young state. Hardy; good soils.

Phyllocladus glaucus-Toaloa, Celery-pine.-Northern iNew Zealand. $30 \mathrm{ft}$. to $40 \mathrm{ft}$. E. Remarkable foliage ; ornamental. Hardy ; any soil.

Phyllocladus trichomanoides-Tanekaha, Celery-pine.-Northern New Zealand. $60 \mathrm{ft}$. to $70 \mathrm{ft}$. E. Remarkable foliage. Timber largely used for posis, \&c. Hardy ; any soil.

Phrllocladus alpinus - Mountain Celery pine. - New Zealand. $20 \mathrm{ft}$. to $30 \mathrm{ft}$. E. Dense-gruwing; ornamental. Hardy; prefers high lands.

Pittosporum buchananit, P. colensoi, P. crassifoliom, P. eugenioides, P. fasciculum, P. Ralphir, P. Tendifolium-Pittosporum.-New Zealand. $10 \mathrm{ft}$. to $30 \mathrm{ft}$. E. Handsome shrubs or small trees; easily grown from seed; ornamental ; invaluable for shelter and hedges (see "Hedge-plants"). Hardy; any soils or situations.

Picea mariana (Abies nigra)-Black-spruce.-Eastern United States. $60 \mathrm{ft}$. to $80 \mathrm{ft}$. E. Dark, dense foliage. Timber light, strong, and elastic. Hardy ; swampy lands.

Picea Canadensis (Abies alba)-White-spruce.-North-eastern United States. $60 \mathrm{ft}$. to $75 \mathrm{ft}$. E. Straight slim growth. Timber tough and durable. Hardy ; swampy lands.

Picea engelmanni-Arizona Spruce.-Arizona, British Columbia. $80 \mathrm{ft}$. to $100 \mathrm{ft}$. E. Tall pyramidal tree. Timber superior and durable. Hardy; high elevations, moist soile. 
Picea sitchensis (Abies menziesii)-Tideland Spruce.-Alaska, North California. $150 \mathrm{ft}$. to $200 \mathrm{ft}$. E. Rapid grower; tapering babit. Timber for all inside purposes; does not resist damp. Hardy; damp sandy soils, coastal districts.

Picea parryana (P. PUngens)-Blue-spruce.-Colorado, Rocky Mountains. $150 \mathrm{ft}$. E. Bluish-green foliage. Timber for ordinary building purposes. Hardy ; wet soils, margins of streams, higb elevations.

Picea excelsa (Abies excelsa)-Norway Spruce.-Europe. $100 \mathrm{ft}$. to $150 \mathrm{ft}$. E. Well-known Spruce-fir. Timber yields the common deal of commerce. Very hardy; cool damp soils of the interior, high elevations.

Pseddo-tsuga taxiforia (Abies douglasil)-Reà-fir, Douglas Fir.-Eastern Columbia, Pacific Coast, \&c. 200 ft. E. The fastest-growing of the Firs. Excellent building-timber; should be largely planted. Hardy; will succeed in any class of soil or situation.

PSEUDO-LARIX KEMPFERI (LARIX KEMPFERI)-Golden-larch. - North-eastern China. $150 \mathrm{ft}$. D. Handsomest of the Larches; quick-growing; golden foliage in autumn. Hard durable timber. Hardy; mountain-slopes, free gravelly soils.

Pinus strobus-Weymouth Pine, White-pine, or Clear Pine.-North America. $150 \mathrm{ft}$. to $250 \mathrm{ft}$. E. Stately tree of quick growth; valuable as shelter. Timber free of knots, light, soft, yet durable. Hardy; does best on poor sandy soils.

Pines monticola-Pacific White-pine, or Silver-pine.-Northern California, Oregon. $75 \mathrm{ft}$. to $100 \mathrm{ft}$. E. Fast grower, fine-leaved. Timber similar to above. Hardy; poor free soils, elevated situations.

Pinus lambertiana - Sugar-pine. - Northern California, Oregon. $200 \mathrm{ft}$. to $250 \mathrm{ft}$. E. Elegant spreading habit. Wood heavy, strong, durable. Hardy ; does best on high lands, sandy or gravelly soils.

Pinus Flexilis-Limber Pine--Rocky Mountains, Sierra Nevada. $80 \mathrm{ft}$. to $100 \mathrm{ft}$. E. Conic symmetrical shape; rapid growth. Wood fine texture, soft, and easily worked. Hardy; sub-alpine regions; does best on limestone.

Pinus palustris (P. Australis)-Long-leaved Pine.-South-eastern United States. $70 \mathrm{ft}$. to $100 \mathrm{ft}$. E. Slow-growing; long-leaved distinct species. Yellow, straight-grained timber, largely used for flooring. Hardy; poor dry sandy soils.

Pinus ponderosa-Heavy or Bull Pine.-North-western America. $100 \mathrm{ft}$. to $150 \mathrm{ft}$. E. Comparatively quick grower. Heavy, dense, durable timher. Hardy; dry sandy soils from sea-level to snow-line.

PINUS TEDA-Loblolly Pine.-South-eastern United States. $50 \mathrm{ft}$. to $80 \mathrm{ft}$. E. Quick growth. Timber used largely for inside fittings. Hardy; moist sandy soils near the coast.

Pints Resixosa-Red-pine.-Minnesota to Michigan. $75 \mathrm{ft}$. to $100 \mathrm{ft}$. E. Of rapid growth; reddish.barked trunk; branches in distinct whorls. Timber fine-grained, durable, reddish. Hardy; free open lands, gravelly or sandy.

Pinus echinata (P. Mitis)-Short-leaved Pine.-United States. $50 \mathrm{ft}$. to $60 \mathrm{ft}$. E. A valuable Pine for timber purposes. Timber resinous and durable. Hardy ; dry sandy or even clayey lands.

Pincs Canariensis-Canary Islands Pine.-Canary Islands. $70 \mathrm{ft}$. to $80 \mathrm{ft}$. E. Fast growth, branches in whorls. Resinous, durable, heavy timber. Medium hardy; light porous lands, suitable for warm localities.

Pinus Jefrerey -Jeffrey Pine.-Sierra Nevada Mountains. $150 \mathrm{ft}$. E. Similar to Pinus ponderosa, but longer needles. Produces valuable timber, strong, tough, and lasting. Hardy; almost any soil and exposure. 


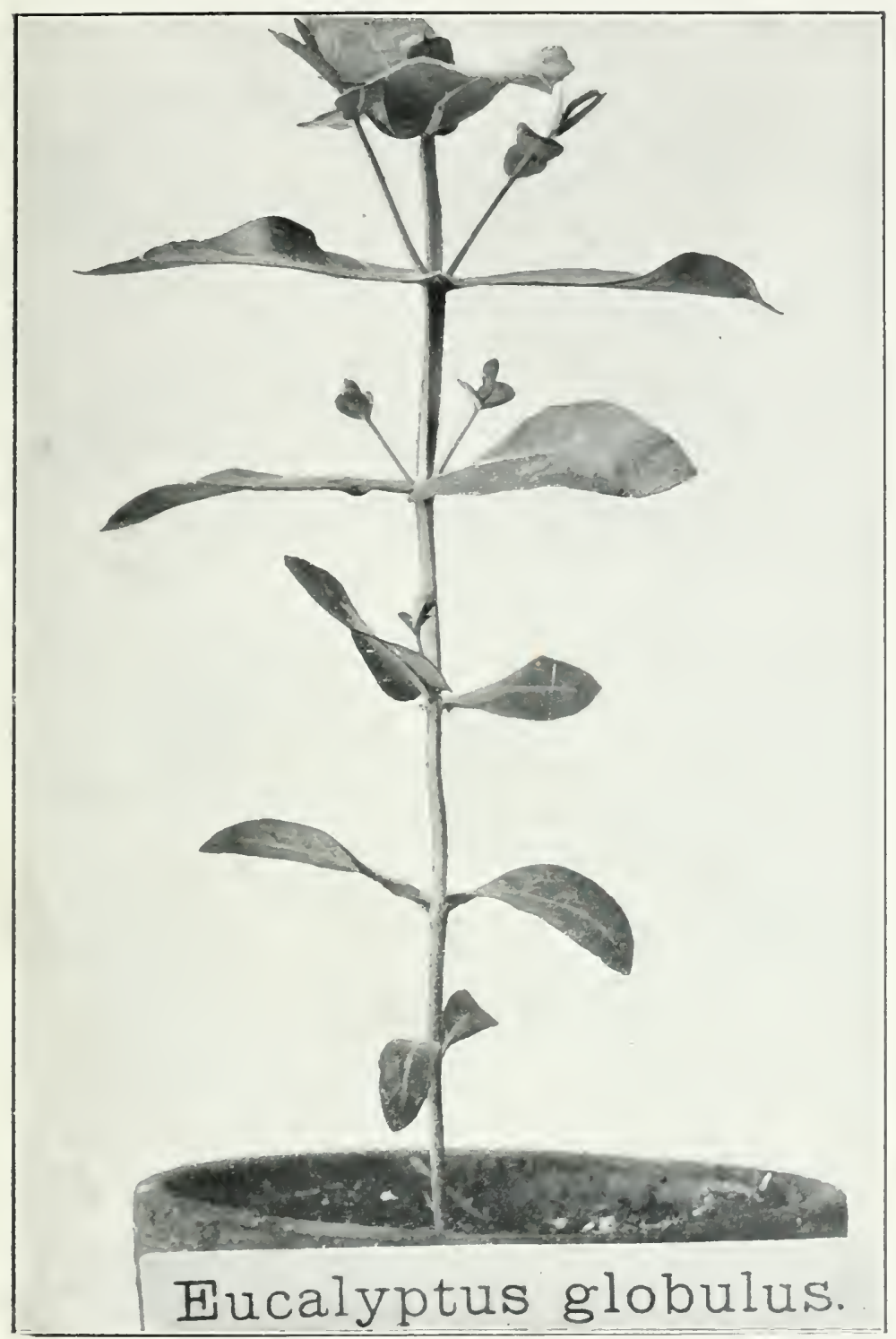

Plate 58.]

SEEDI.IXF, SIX MONTHS OLD.

[Fare p. 116 . 

Pinus Rigida-Pitch pine.-New England to Virginia. $80 \mathrm{ft}$. E. Stiff, short, deep-green foliage; excellent shelter. Resinous timber, strong and durable. Hardy; light, deep, sandy soils down to the coast.

Pinus virginiana (P. INops)-Jersey or Scrub Pıne.-Eastern North America. $40 \mathrm{ft}$. E. Tree of scrubby irregular growth. Timber highly resinous. Hardy ; valuable tree for sand-drifts.

Pinus albicaulis- White-bark Pine.-British Columbia, California. $60 \mathrm{ft}$. E. Branches and twigs whitish. Yellowish timber, tough and durable. Hardy; only fit for high altitudes, open rocky soils.

Pinus contorta (P. murrayiana, P. bolanderi) - Shore or Twisted Pine.Alaska to California. $50 \mathrm{ft}$. $1060 \mathrm{ft}$. E. Pine of peculiar growth; excellent sbelter. Pale, straight-grained timber. Hardy; rocky billsides.

Pinus Sabiniana-Grey-pine-California. $150 \mathrm{ft}$. E. Foliage pale bluishgreen; large cones, and edible seeds. Hard, durable timber. Hardy; moist, free, open soils.

Pinus coteteril (P. Macrocarpa)-Coulter's Pine-California. $100 \mathrm{ft}$. E. Of quick growth; immense cones; spreading limbs. Close-grained, beavy timber. Hardy ; mountain-slopes, gravelly soil.

Pinos Radiata (P. insignis)-Monterey Pine.-California. $100 \mathrm{ft}$. E. The commonest Pine; a good shelter-tree; requires plenty of space. Hardy; any soil or situation, except southern inland districts.

Pinds attenuata (P. tuberculata)-Knob-cone Pine.-California. $40 \mathrm{ft}$. to $50 \mathrm{ft}$. E. Retains its cones for many years. Chiefly for shelter. Hardy; rocky mountain-sides.

Plivos muricata-Prickly-coned or Bishop's Pine.-Califormia. $40 \mathrm{ft}$. to $60 \mathrm{ft}$. E. Dense-growing tree; one of the best for shelter. Hardy; any soil down to high-water mark on pure sand.

Pluvs austriaca - Austrian Pine.-Southern Europe. $75 \mathrm{ft}$. to $100 \mathrm{ft}$. E. Close growing heavy foliage; splendid shelter. Durable timber for posts and sleepers. Hardy; will grow on any soil or situation.

Pinus Halepersis - Aleppo Pine.-Mediterranean. $80 \mathrm{ft}$. E. Deep-green foliage. Resinous timber, used for joinery. Hardy; poor light soils.

Pinus Laricio-Corsican Pine.-Southern Europe. $100 \mathrm{ft}$. to $140 \mathrm{ft}$. E. Fastgrowing pyramidal tree. Probably the best Pine for timber-production for this colony. Hardy ; any soil from sand to stiff clay.

Pines pinister (P. Maritima) -Cluster-pine.-Southern Europe. $40 \mathrm{ft}$. to $60 \mathrm{ft}$. E. Branches in regular whorls, tap-rooted; valuable shelter-tree; yields resin and turpentine. Hardy; any soil and situation.

Pinds Prisa-Srone-pine.-Southern Europe. $50 \mathrm{ft}$. to $60 \mathrm{ft}$. E. Large and spreading; dense foliage; round cones. Timber suitable for general carpentry. Hardy; deep light soils; does well in pumice.

Plvos Cembra - Swiss Stone-pine. - Central Europe. $50 \mathrm{ft}$. to $100 \mathrm{ft}$. E. Branches in whorls; slow growth. Light-brown tımber, used for furniture, \&c. Hardy; dry light soils.

Pixts excelsa (P. Pendula).-Himalayan Mountains. $100 \mathrm{ft}$. E. Fine tree, cf easy cultivation. Soft, easily worked timber. Hardy; any soil not wet.

Pines torreyana (P. LOphosperma)-Torrey's Pine.-Southern California. $60 \mathrm{ft}$. to $80 \mathrm{ft}$. E. Broad-branching; the stoutest needles of any Pine. Excellent timber, straignt-grained and resinous. Hardy; grows remarkably well on poor pumice lands.

Pindes ponderosa, var. Benthaniana-Bentham's Pine.-British Columbia. $100 \mathrm{ft}$. to $150 \mathrm{ft}$. E. Magnificent tree; quick growth. Produces valuable timber for joinery purposes. Hardy ; content with any soil or situation. 
Plagianthus Betulinus-Ribbonwood, Manatu.-New Zealand. $20 \mathrm{ft}$. to $60 \mathrm{ft}$. E. or D. Graceful habit; white flowers, freely produced; ornamental. Hardy ; does best oll river-banks and moist lands.

Platayus occidentalis (P. vulgaris) - American Plane or Buttonwood.Easteru North America. $100 \mathrm{ft}$. D. Large spreading tree; ornamental; splendid avenue or street tree. Hardy; any free open soil; easily raised by cuttings.

Platanos orientalis-Oriental Plane.-Southern Europe. $50 \mathrm{ft}$. to $70 \mathrm{ft}$. E. Of quick growth; ornamental; spiendid avenue or street tree. Halfhardy; free opeu soil (killed at Dunedin in winter of 1902); easily raised by cuttings.

Populus AlBA-Abele or White Poplar,-Europe, Asia. $90 \mathrm{ft}$. to $100 \mathrm{ft}$. D. White foliage; free growth; chiefly shelter where other trees cannot exist. Hardy ; any soil, dry or moist.

Popdlus tremoloides-Ámerican Aspen.-North America. $50 \mathrm{ft}$. to $60 \mathrm{ft}$. D. Very fast grower; shelter, ornament. Timber light, tough, and easily worked. Hardy; ascends to an alpine situation, moist soils.

Populus tremela-English Aspen.-Europe, Asia, \&c. 100 ft. D. Rather slow growth; handsome tree. Produces the timber from which wooden matches are made. Hardy; any moist soil.

Populus grandidentata (P. Deltoides)-Large-toothed Poplar.-Eastern North America. $80 \mathrm{ft}$. D. Downy-leaved, fast-growing; produces immense bole. Timber durable if not in contact with soil. Hardy; any moist soll.

Populus balsamimera (P. Candicans)-Balsam Poplar.-North America. $80 \mathrm{ft}$. D. Rapid grower, heart-shaped leaves. Timber used for packing-cases. wheelbarrows, \&c. Hardy ; banks of streams and other moist places.

Popolus deltoides (P. monilifera, P. Canadensis)-Canadian or Black Italian Poplar.-North America. $100 \mathrm{ft}$. to $150 \mathrm{ft}$. D. Upright growth; large stem, smail branches. Probably the best Poplar for timber purposes; used for dray.bottoms, \&c. Hardy ; strong retentive loam.

Populus pyramidalis (P. Fastigata)-Lombardy or Italian Poplar.-Italy. $100 \mathrm{ft}$. D. Tall and narrow growth; few upright branches; good for quick shelter. Timber for packing and fruit-cases.

Populus nigra (P. viminea)-Black-popiar.-Europe, China, Inảia. $150 \mathrm{ft.}$ D. Extremely rapid grower; pale, shiny, green leaves; ornamental and shelter. Produces light timber for fruit-cases, \&c. Hardy; damp or stagnant soils.

Pronus serotina-Black-cherry.-Eastern North America. 100 ft. D. Rapidgrowing; ornamental. Produces valuable timber for furniture. Hardy; deep rich soils; stands salt epray.

Prrus aUCUPAria (Sorbus aUCUPARia)-Roman or Mountain Ash.-Europe, Asia, \&c. $30 \mathrm{ft}$. to $50 \mathrm{ft}$. D. F'ast upright grower; ornamental and shelter. Timber tough, used for farm-implements. Hardy; any soils, poor or rich ; stands any exposure.

Pyrus sorbus (Sorbus terminalis)--Service-tree--Europe, Asia, $60 \mathrm{ft}$. D. Fairly fast grower; ornamental and sbelter. Hardy; any soils, poor or rich; stands any exposure.

Prumnopitys spicatus (Podocarpus spicatus)-Matai, or Black-pine.-New Zealand. $60 \mathrm{ft}$. to $80 \mathrm{ft}$. E. A well-known timber-tree by a new name. Timber very durable. Hardy; requires shade, especially to the roots in all stages of growth.

Quercus pedunculata (Q. Robur)-British Oak.-Europe, Western Asia. $80 \mathrm{ft}$. to $100 \mathrm{ft}$. D. Well-known tree; ornamental and shelter. Durable timber of great strength. Hardy; does best in heavy, moist lands. [The acorns of all species of Oak should be sown where they are to remain.] 


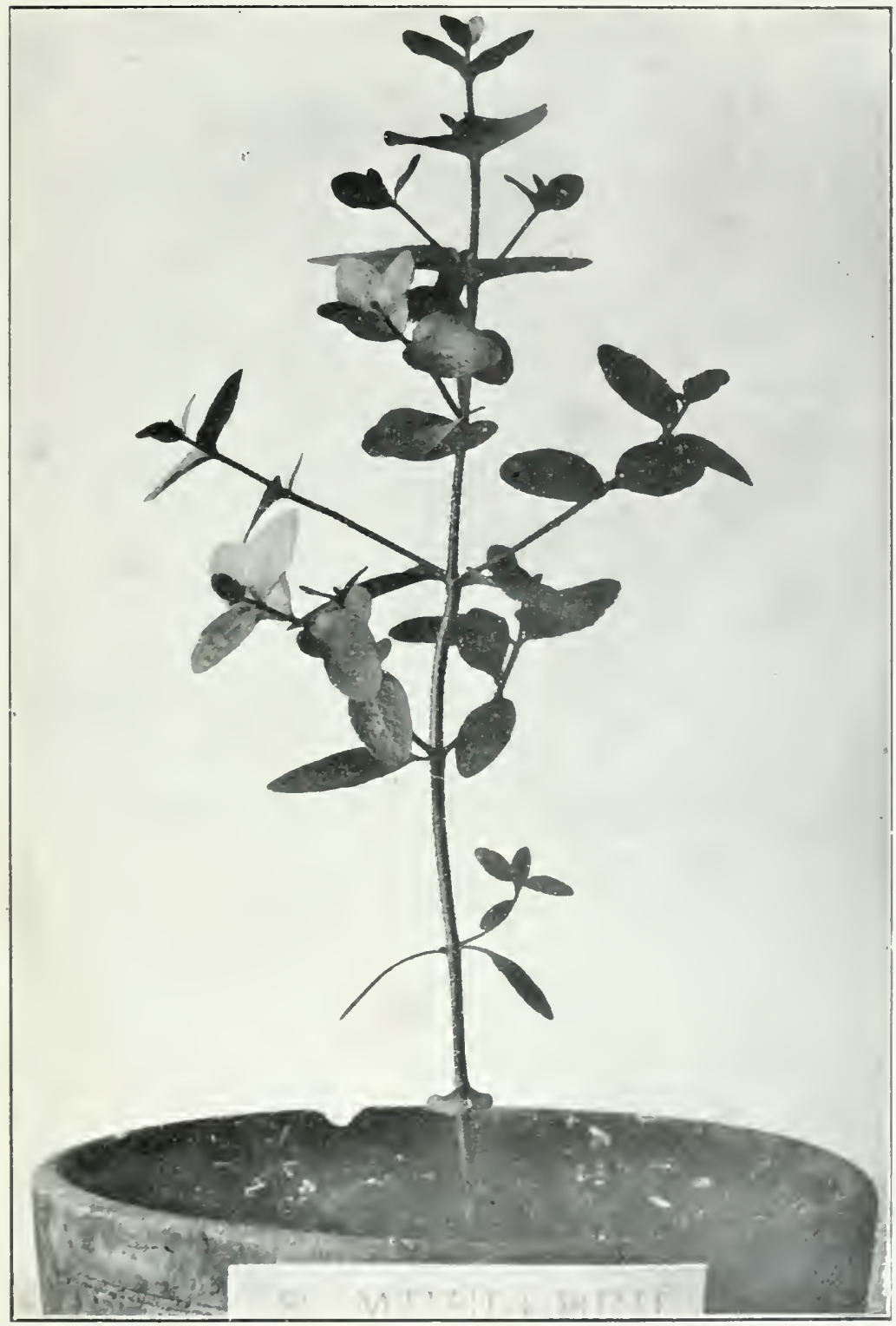

I'lite 59.]

ETCAIPPTE's MtEIIURI, SHY MONTHS OID.

[Fuce p. 118. 
Senecio Rotundifolius - Puharatiko - Mutton-bird scrub.-New Zealand. $10 \mathrm{ft}$. to $20 \mathrm{ft}$. E. Very large leathery leaves. Ornamental and shelter. Hardy; cool soils, southern localities near the coast.

SALIX ALBA- White or Huntingdon Willow.-Europe, Western Asia. $60 \mathrm{ft}$. to $70 \mathrm{ft}$. D. Rapid-growing; lance-shaped leaves; ornamental. Timber the best for dray and barrow bottoms ; tough, and difficult to split. Hardy; deep moist soils along river-bauks.

Salix FRagilis (S. MaScULA) -Cracking or Redwood Willow.-Europe, Western Asia. $60 \mathrm{ft}$. to $70 \mathrm{ft}$. D. Rapid-growing; leaves resemble above, but are downy on young growth; ornamental. Timber reddish and light, valuable for flooring. Hardy; moist lands, but will do on dry gravelly soils.

Salix Fragilis, var. RUSselliana (S. RUSSElliana) - Bedford Willow.Britain. $70 \mathrm{ft}$. to $80 \mathrm{ft}$. D. Fast-growing; leaves toothed, smooth on both sides; ornamental. Timber same as above. Hardy; any moist soil.

Salix babrlonica (S. Pendula) - Weeping Willow.-Japan, $60 \mathrm{ft}$. D. Graceful sbade-tree; ornamental. Hardy; along river-banks.

Salix triandra (S. amygdalina)-Almond or French Willow,-Europe, North Asia. $30 \mathrm{ft}$. D. Upright growth; a good basket-willow. Hardy; rich loamy soil, moist.

Salix viminalis (S. Longifolia)-Common Osier.-Europe, Northern and Western Asia. $30 \mathrm{ft}$. D. The common basket-willow. Chiefly for basket-work. Hardy; rich loamy soils, moist.

Salix daphyotdes, var. acutifolia (S. CAspica)-Caspian Willow.--Europe, $\& c .60 \mathrm{ft}$. D. Fast-growing; large tree. One of the best basket-willows, valuable for binding embankments. Hardy; damp soils, but does well on dry land.

SALIX PURPURea-Bitter Willow.-Europe, Asia. $40 \mathrm{ft}$. D. Very rapid growth. Largely grown in England for basket-work. Hardy; light sandy or gravelly soils.

Salix Babylonica, var. SAlmonim-Salmon's Willow.-Asia Minor. $60 \mathrm{ft}$. to $70 \mathrm{ft}$. D. The fastest-growing Willow known; splendid for quick shelter. Hardy; any soil or situation.

Salix Viteldina-Golden-osier.-Britain. $30 \mathrm{ft}$. to $50 \mathrm{ft}$. Branches golden; good tree for specimen-planting among other trees. Hardy; any moist soil.

Schefflera digitata-Patete-Five-finger.-New Zealand. $10 \mathrm{ft}$. to $25 \mathrm{ft}$. E. Soft-wooded tree; ornamental. Hardy ; requires sbade, damp soil.

Sideroxylon costatum (Sapota costata) - Tawapou. - Northern New Zeaiand. $30 \mathrm{ft}$. to $50 \mathrm{ft}$. Erect evergreen; handsome fruits; ornamental ouly. Tender; situations near the sea, North Auckland only.

Sophora tetraptera (Edwardsia microphylla)-Kowhai.-New Zealand. $40 \mathrm{ft}$. to $60 \mathrm{ft}$. E. or D. Well-known tree; yellow flowers; ornamental. Timber very durable, lasting in the ground. Hardy; free open soil, near creeks and river-courses.

Sophora tetraptera, var. GRANDIFLora-Large-flowered Kowhai.-Northern New Zealand. $30 \mathrm{ft}$. to $50 \mathrm{ft}$. E. or D. Handsome foliage and large yellow flowers; ornamental. Timber inferior to above. Hardy; free open soil.

Sophora macrocarpa (Edwardia chilensis).- Chili. $40 \mathrm{ft}$. to $60 \mathrm{ft}$. E. Fast-growing; pendulous babit; ornamental. Timber durable and strong. Hardy ; any soils or situations.

Sciadopitys venticillata - Umbrella-pine. - Japan. $80 \mathrm{ft}$. to $120 \mathrm{ft}$. E. Slow-growing; pyramidal growth ; ornamental. Hardy; dry soils. 


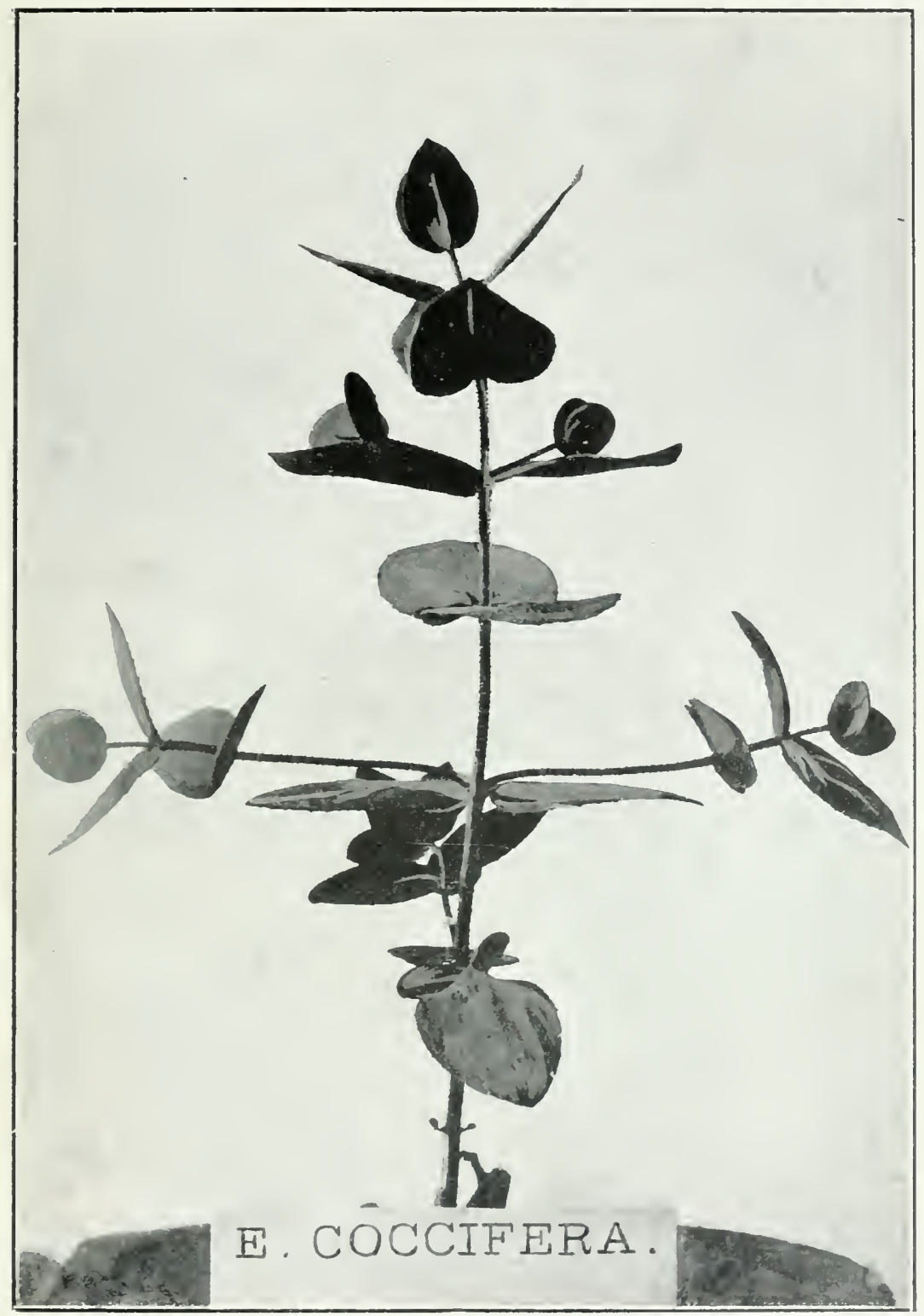

Plate 60.]

[Face p. 120. 

Sequoia Washingtoniana (Wellingtonia gigaxtea, Sequoia gigantea)(Wellingtonia) - Big-tree. - California. $450 \mathrm{ft}$. E. One of the most colossal trees; fast-growing; ornamental. Durable timber, though soft. Nearly hardy ; requires good drainage; any situation not exposed. (Killed by frost in central Otago, 1903.)

Sequoia sempertirens (TAxodium sempertirens) - Redwood. - Califormia. $360 \mathrm{ft}$. E. Fast-growing; feathery foliage; ornamental. Soft, easily worked timber, exceedingly durable. Hardy; numid, free open soils.

Taxodium distichum - Bald or Swamp Cypress. - Eastern North America. $100 \mathrm{ft}$. to $120 \mathrm{ft}$. D. Handsome tree, with beautiful light-green foliage. Hard, strong, elastic timber. Hardy; mo; st but not stagnant soils. In. creased by cuttings.

Tsega canadensis (Abies caxadensis) - Canadian Hemlock. Northern States. $100 \mathrm{ft}$. to $150 \mathrm{ft}$. E. Fest-growing tree, spreading branches; ornamental and shelter. Coarse, strong timber for general building. Hardy; cool moist climates, deep heavy soils.

Tsuga heterophylla (Abies mertensiana) - Western Hemlock. - Pacific Coast. $100 \mathrm{ft}$. to $150 \mathrm{ft}$. E. Large-growing; ornamental and shelter. Coarse, strong timber for general building. Hardy; cool moist climates, deep moist soils.

Tsega mertensiana (Tsuga or Abies pattoniana)-Black Hemlock.-Northern Britısh Columbia, \&c. $100 \mathrm{ft}$. to $150 \mathrm{ft}$. E. Graceful round-headed tree; ormamental and shelter. Straight-grained timber. Hardy; cool moist climates, deep beavy soils.

Taxds Baccata-English Yew.-Europe, Asia. $30 \mathrm{ft}$. to $40 \mathrm{ft}$. E. Very slow growth; ornamental; leaves and fruit highly poisonous. Hardy; deep moist soils; stands shade well.

Thoja occidentalis (CUpressus arbor-vite.) - Atlantic Red-cedar, or American Arbor-vitæ.-North-eastern America. $40 \mathrm{ft}$. to $60 \mathrm{ft}$. E. Immense tapering growth. Light timber; resists damp; largely used for building in America. Hardy; moist free soils, sheltered situations.

Thuja plicata (T. gigantea, T. Lobbi)-Paciâc Red-cedar. - Pacific Coast. $100 \mathrm{ft}$. to $150 \mathrm{ft}$. E. Rapid grower; tapering babit; ornamental. Timber as above. Hardy; moist free soils, sheltered situations.

Tilia Americana-Basswood or Linden-tree.-North America. $60 \mathrm{ft}$. to $80 \mathrm{ft}$. D. Grod street-tree; spreading-branched head; ornamental; good shadetree. Timber soft; used for musical instruments. Hardy; deep moist soils; requires shelter.

Tilia volgaris (T. europea)-Linden or Lime.-Europe, \&c. $70 \mathrm{ft}$. to $80 \mathrm{fc}$. D. Well known; very ornamental; good shade-tree. Timber soft; used for musical instruments. Hardy ; deep moist soils.

Tomon CALIForNicum (TORREYA CALIFORNica) - Californian Nutmeg-tree.California. $50 \mathrm{ft}$. to $75 \mathrm{ft}$. E. Symmetrical growth, much resembling the Yew; ornamental. Hard, firm timber. Hardy; open dry solls.

Ulmos amertcaxa - White-rock or Swamp Elm. - North America. $80 \mathrm{ft}$. to $100 \mathrm{ft}$. D. Graceful tree; rapid growth; ornamental; good streettree. Wood fibrous, difficult to split; used by wheelwrights. Hardy; deep moist soils.

Ulmus PUbescens (U. FULVA)-Slippery or Red Elm.-Eastern North America. $50 \mathrm{ft}$. to $60 \mathrm{ft}$. D. Splendid tree for streets and avenues; rather slow growth; ornamental. Timber used for wagon-hubs, \&c. Hardy; deep moist soils.

Ulmos Racemosa-American Cork-elm.-North America. $40 \mathrm{ft}$. to $50 \mathrm{ft}$. D. Dark-green foliage; umbrageous. Heavy, tough, flexible timber, used for coachbuilders' work. Hardy; deep moist soils. 
Ulmus CaMpestris-English Elm.-Europe, North America, \&c. $80 \mathrm{ft}$. to $120 \mathrm{ft}$. D. Well-known tree; small leaves, which are doubly toothed; produces suckers; orommental. Timber tough ; used for furniture, blocks, \&c. Hardy ; deep moist soils.

Ulmos CAMPESTRIs, var. SUBERosa-Cork or Dutch Elm.-Europe. $60 \mathrm{ft}$. to $80 \mathrm{ft}$. D. Much resembles above. Ornamental; produces corky bark. Hardy ; deep moist soils.

Ulmos montana (U. Nigra)-Mountain, Scots, or Wych Elm.-Europe. 50 ft. to $70 \mathrm{ft}$. D. Large leaves; does not produce suckers; ornamental. Timber as above. Hardy; moist soils.

Vitex Littonalis - Puriri. - Northern New Zealand. $40 \mathrm{ft}$. to $60 \mathrm{ft}$. E. Magnificent spreading tree; pink flowers, red fruit; ornamental. Durable, heavy hard timber, lasting in contact with the ground. Half-hardy; coastal districts of North Island only; almost any soils suit if not wet.

Veronica ARBorea, V. BUXIFolia, V. COLENSOI, V. ELLIPTICA, V. LAVIS, V. LigUSTRIFOLIA, V. MACROCARPa, V. PARVIFlora, V. SAliCiFOlia, V. Speciosa, V. traversil-Veronica or Koromiko.-New Zealand. $6 \mathrm{ft}$. to rarely $15 \mathrm{ft}$. or $20 \mathrm{ft}$. E. Handsome flowering-shrubs; easily grown, and free-flowering; ornamental; good shrubs for planting on the outskirts of plantations. Hardy; almost any soil; all are easily produced by cuttings in the autumn.

Weinmannia Racemosa-Kamali, Towai.-New Zealand. $90 \mathrm{ft}$. to $100 \mathrm{ft}$. E. Handsome evergreen; racemes of white flowers; exceedingly variable foliage; ornamental and shelter. Light-brown timber.. Hardy, except in interior of Canterbury and Otago; seens to do well in poor soils.

Weinmannia syluicola-Tawhero.-Northern New Zealand. $40 \mathrm{ft}$. to $70 \mathrm{ft}$. E. Very similar to above; ornamental and shelter. Light-brown timber. Hardy ; moist poor lands. 


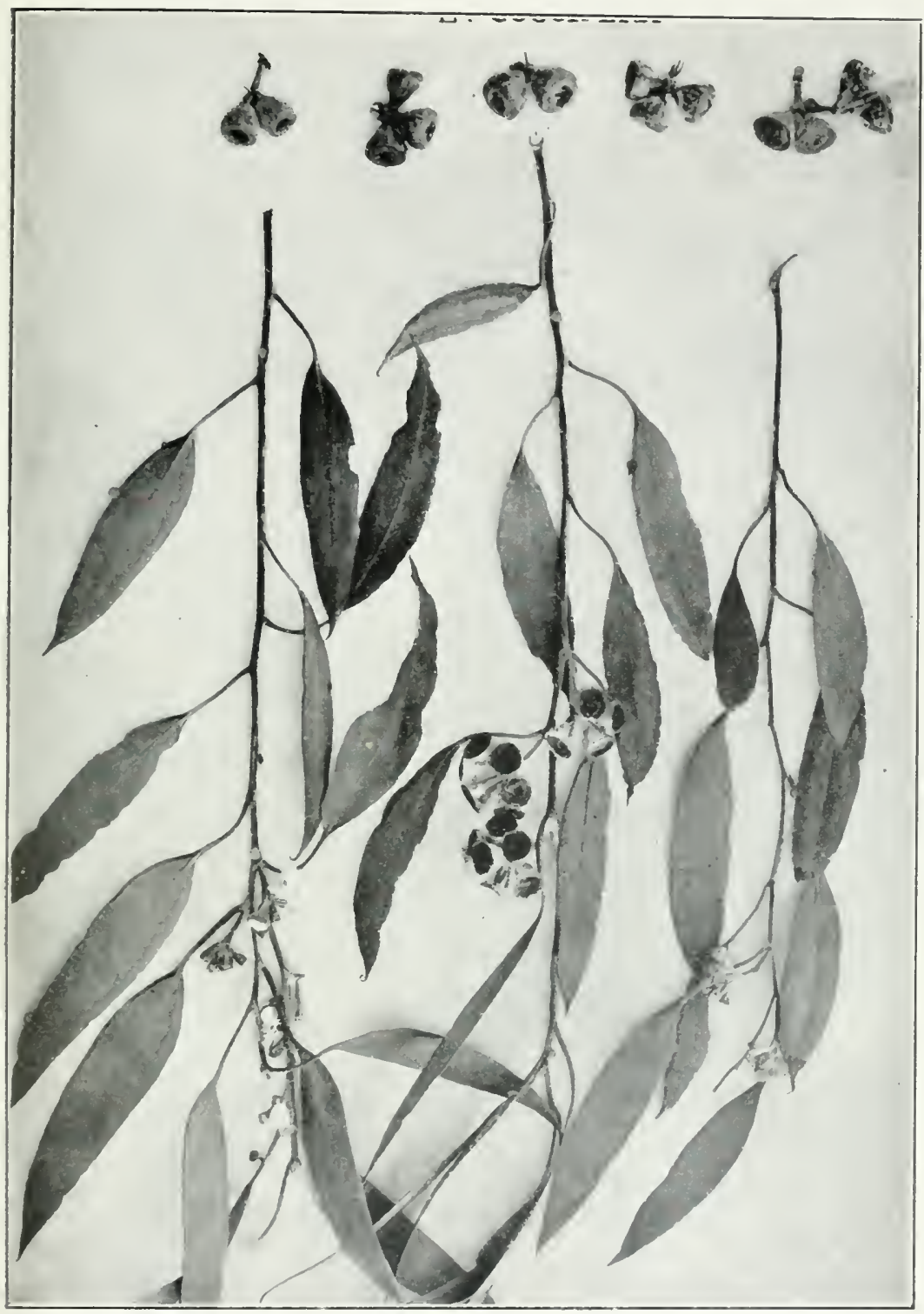

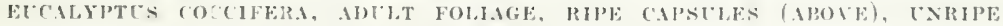
Plate 61.]

[Face p. 12? 



\section{APPENIIX II.}

\section{TREES FOR SPECIAL PURPOSES.}

Is the following list of trees recommended for special purposes, only those species which are easily and cheaply raised from seeds (or cuttings) are enumerated.

List of Trees best adapted for the Growtil of Timber for Fllíwood.

ACACIA DEALBata (Silver-wattle).

A. DECURRENS (Black-wattle).

EUCalyptus amygdalina (Almond-leaved Peppermint Gum).

E. COCCIFERA (Mountain Peppermint Gum).

E. OBLIQUA (Stringy-bark Gum).

E. PAUCIFLORA (Drooping Gum).

E. Goniocalyx (Spotied Gum).

E. LEUOXYLON (Red-ironbark).

E. RESINIFERA (Forest Mahogany).

E. TERETICORNIS (Red-gum).

E. sieberiana (Tasmanian Ironbark).
E. MFLLIODORa (Yellow-box).

E. Hamastoma (Gum-topped Stringybark).

E. regnans (Giant Gum).

E. Stuartiana (Apple-scented or Tas. manian Red-gum).

E. URNiGEla (Unn-bearing Gum)

PINEs, nearly all species.

Populus tremuia (Aspen Poplar).

Qunrcus Peinunculata (Englisb Oak).

Q. SESSILIFLORA (Sessilc Oak).

ROBINIA PSEUDO-ACACIA (Black-locust).

List of Trens best adapted for the Growth of Thmeer for Sllephis, Fencen POSTS, ETC.

Castanea sativa (Spanish Chestnut). Catalpa speciosa (Hardy Catalpa).

Eccalyptus Crebra (Narrow-leaved Ironbark).

E. Coccrfers (Mountain Peppermint (ium).

E. OBLIQUA (Stringy-bark Gum).

E. PAcCiflora (Drooping Gum).

E. pilularis (Blackbutt).

E. PIPERita (Peppermint Gum).

E. Polynanthema (Red-box Gum).

E. Goniocalyx (Spotted Gum).

E. LELOXYLoN (Red-Ironbark).

E. RESINIFERA (Forest Mabogany).

E. IERETICORNIS (Red-gum).

E. MARGINATA (Jarrah).

F. SI B BERIaNa (Tasmanian Ironbark),

E. YUELLERII (Mountain Red-gum).

E. MiCrocorys (Tallow-wood).

E. MELLIODORA (Yellow-box).
E. CORynocalyX (Sugar-gum).

E. Himphloia (White-box).

E. Paniculata (Red-ironbark).

E. GUNNII (Cider-gum).

E. stuartiana (Apple-scented or Tas. manian Red.gum).

E. postrata (Red-gum).

F. SIDERopillois (Red-ironbark).

E. UINIGERA (Urn-bearing Gum).

GLentTochí tricanthos (Honey-locust).

Joniperus virginiana (American Redcedar).

JAKIX FUROPAA (European Larch).

Pinus austriaca (Austrian Pine).

P. Laricio (Corsican Pine).

P. Muricata (Prickly-coned Pine).

Querctus PEDUNCULaTa (English Oak).

Q. SEsSilfflora (Sessile Oak).

Robivia I'SEUDO-ACACia (Black-locust).

Sophora tetratera (Kowhai).

List of Trees best adapted fop Shelter Purposes.

Evergreen Species.

Acacia dealeata (Silver-wattle).

A. DECURRENS (Black-wattle).

A. MELAziOXYLON (Blackwood).

A. PYHaCANTHA (Golden-wattle).

Cormocarpub levigata (Karaka).
Chamacyparis lawsomiana (Lawson's Cypress).

CUPRFsSU MaCrocappa (Monterey Cy. press).

C. GOVENiana (Goven's Cypress). 
List of Trees best adapted for Shelter Purposes-continued. Evergrcen Species-continued.

C. torulosa (Tufted Cypress).

Eucalyptus, many species (see alpha-
betical list).

Picea EXCElsa (Norway Spruce).

P. Sitchensis (Tideland Spruce).

Pseudo-tsuga taxifolia (Douglas Fir).

Pinus canariensis (Canary Island Pine).

P. contorta (Twisted Pine).

P. ponderosa (Heavy Pine).
P. Radiata (Monterey Pine).

P. pinaster (Cluster Pine).

P. auricata (Prickly-coned Pine).

P. strobus (White-pine).

P. Austriaca (Austrian Pine).

P. LARICIO (Corsican Pine).

P. RIGIDA (Pitch-pine).

QUERCUS ILEX (Evergreen Oak).
Alinus glutinosa (Alder).

Acer canpestre (British Maple).

A. PSEudo-Platanus (Sycamore).

Betula Alba (Silver-birch).

Castanea sativa (Spanish Chestnut).

Fagus sylvatica (English Birch).

LIRIODENDRON TULIPIFERA (Tulip-tree).

LARIX EUROPAA (European Larch).

\section{Deciauous Species.}

Platanus orientalis (Oriental Plane).

Populus, all species (Poplars).

Pyrus aucuparia (Mountain Ash).

Quercus pedunculata (British Oak).
Q. Sessiliflora (Sessile Oak).

Salix saldionir (Salmon's Willow).

ULMUS CAMPESTRIS (English Elm).

List of Trees generalis Recommended for Extensive Planting for Thmber Purposes.

ACACIa MELANOXYlon (Blackwood).

Chamacrparis NUTKensis (Yellow -
cedar).

CaRYa OLIVEForms (Pecan-nut Hickory).

EUCALYPTUS, many species (See list below).

Juniperus virginiana (American Redcedar).

Picea canadensis (White-spruce).

P. sitchensis (Tideland Spruce).

P. Excelsa (Norway Spruce).

Pseudo-tsuga taxifolia (Douglas Fir).
Species.

Pinus strobus (Weymouth Pine).

P. Lambertiana (Sugar-pine).

P. ponderosa (Heavy Pine).

P. Coulterir (Coulter's Pine).

P. Laricio (Corsican Pine).

P. PONDERosa, var. Benthamiana (Ben. tham's Pine).

Podocarpus totara (Totara).

SEQUOIA SEMPERVIRENS (Redwood).

Tsuga canadensis (Canadian Hemlock).

ThuJa occioentalis) (Red-cedar).

\section{Eucalypts.}

EUCALYPTUS AMYgdalina (Almond-leaved Peppermint Gum).

E. CREBRA (Narrow-leaved Ironbark).

E. MaCulata (Spotted Gum).

E. OBLIQUA (Stringy-bark Gum).

E. PILUlaris (Blackbutt).

E. GONIOCALYX (Spotted Gum).

E. LEUCOXYLON (Red-ironbark).

E. REsiniferia (Forest Mahogany).

E. TERETICORNIS (Red-gum).

E. GLOBUlus (Blue-gum).
E. MARGinata (Jarrah).

E. GOMPHOCEPHALA (Tooart).

E. MUELLERII (Mountain Red-gum).

E. Microcorys (Tallow-wood).

E. CORYNOCALYX (Sugar-gum).

E. HEMIPHLOIA (White-box).

E. REGNANS (Giant Gum).

E. PANICULATA (Red-ironbark).

E. Diversicolor (Karri-gum).

E. rostrata (Red-gum).

E. SIDEROPHLOIA (Red-ironbark.)

\section{Deciduous Species.}

ACER PSEUdo-Platanus (Sycamore).

A. SACCHARUM NIGRUM (Sugar-maple). Alnus Glutinosa (Alder).

Castanea sativa (Spanish Chestnut).

Catalpa speciosa (Hardy Catalpa).

Fraxinus excelsior (English Ash).
JUGLANS RkGiA (Walnut).

J. NIGRA (Black-walnut).

LARIX EUROPAE (European Larch). Quercus pedunculata (British Oak). RoBINIA PSEUDO-ACACIA (Black-locust).

ULMUS CAMPESTRIS (English Elm). 


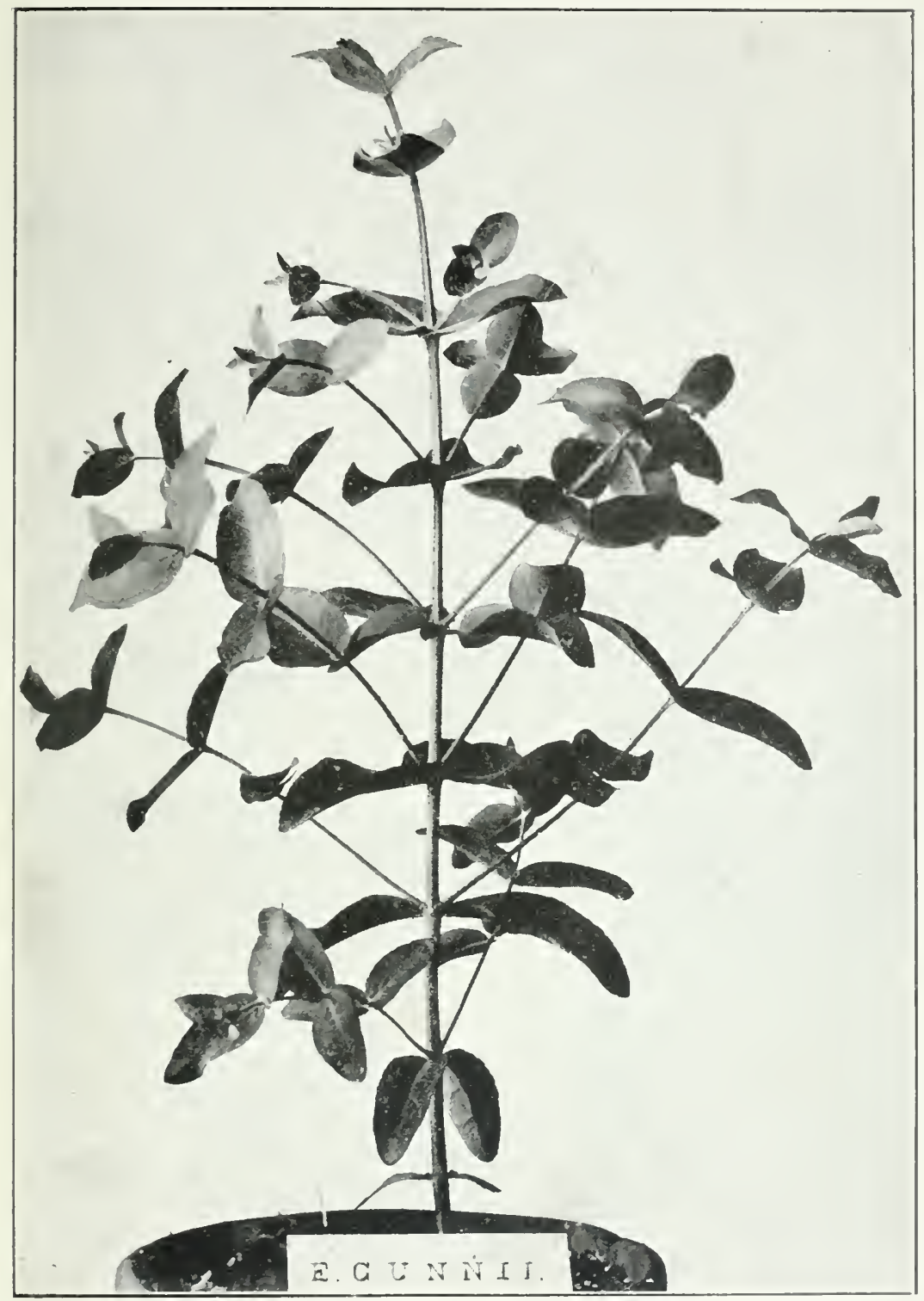

Plite 62.]

[Face p. 124. 



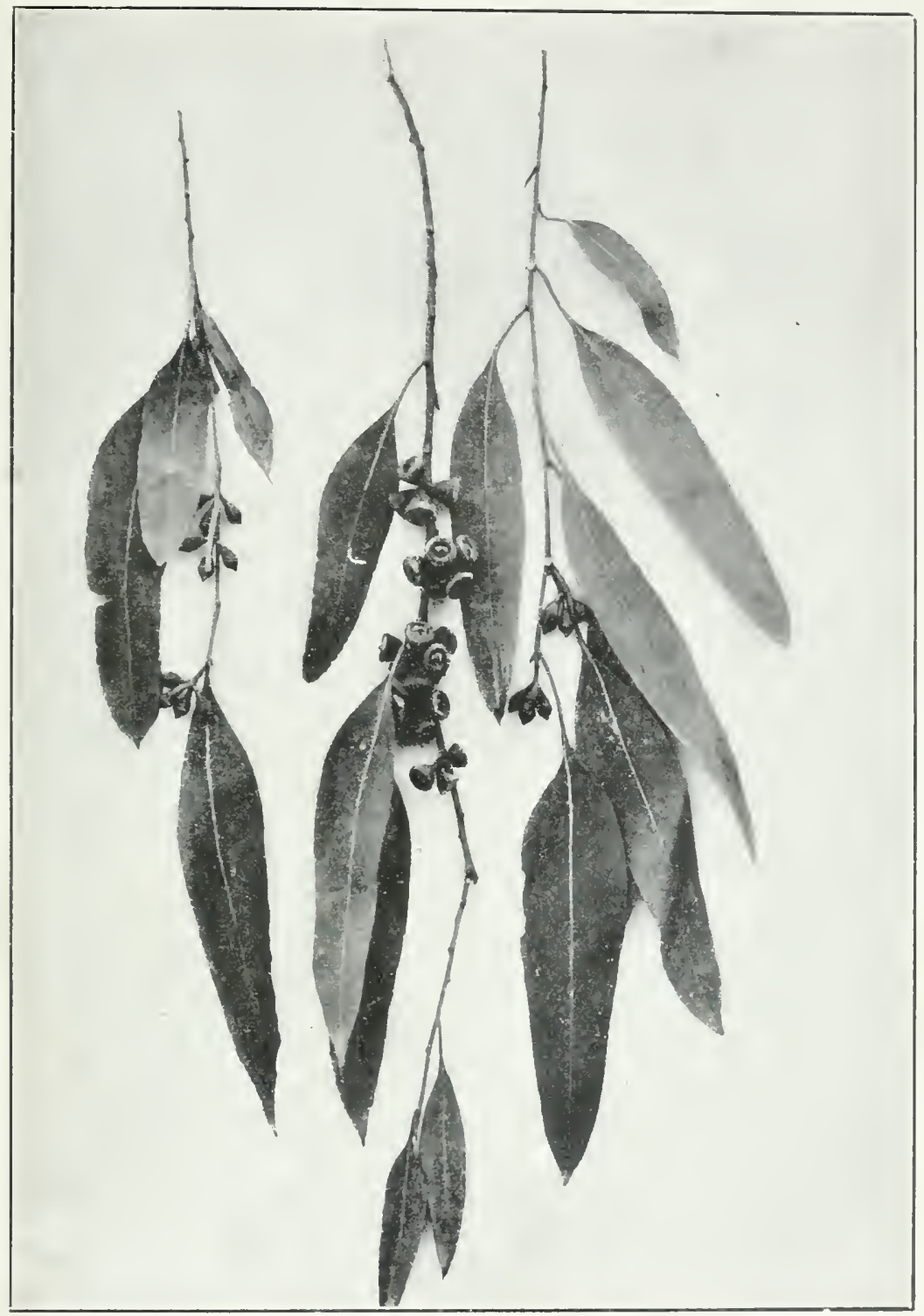

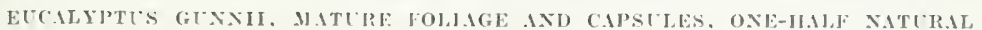
Plute 63.] SIZE.

[Face 1. 126. 




\section{APPENDIX III.}

\section{AVAILABLE WORKS ON FOFESTRY AND KINDRED SUBJECTS.}

\section{British Publications.}

Pine Plantations of France. J. C. Brown. Edinburgh, 1878.

Trees of Commerce. W. Stevenson. London, 1880.

Manual of Coniferce. J. Veitch and Sons. London, 1881.

Manual of Sylviculture (2 vols.). G. Bagneris. London, 1876-82.

Organization and Valuation of Forests. J. L. L. Macgregor. London, 1883.

Forestry and Forest Products. J. Rattray and H. R. Mill. Edinburgh, 1885.

Timbers and how to know them. W. Somerville. London, 1890.

Timber and Timber-trees. Thomas Laslett and M. Ward. London, 1892.

Timber and Some of its Diseases. Marshall Ward. London, $1^{\circ} 8^{\circ}$

Protection of Woodlands. J. Nisbet. Edinburgh, 1893.

British Forest-trees. J. Nisbet. London, 1893.

Studies in Forestry. J. Nisbet. Oxford, 1894.

Practical Forestry (2nd edition). A. D. Webster. London, 1894.

Manual of Forestry (5 vols.). W. Schlich. London, 1887-96.

The Forester (6th edition). J. Brown and J. Nisbet. Edinburgh, 1894.

Practical Forestry. Charles C. Curtis. London, 1898.

The New Forestry. John Simpson. Sheffield, 1900.

Our Forests and Woodlands. John Nisbet. London, 1900.

\section{Colonial Publications.}

Durability of New Zealand Timbers. Kirk, Balfour, and Ward. Wellington, 1875.

Eucalyptographia (10 vols.). F. von. Mueller. Melbourne, 1879.

Tree-culture in South Australia. J. E. Brown. Adelaide, 1881.

Timber-trees of New South Wales. Arvid Nilson. Sydney, 1884.

New Zealand Forests and the Timber Industry. Kirk, Balfour, and Ward. Wellington, 1875.

Select Extra-tropical plants. Mueller. Melbourne, 1891.

Forest Flora of New Zealand. T. Kirk. Wellington, 1889.

Art Album of New Zealand Flora. E. H. and S. Featon. Wellington, 1889.

Report of Timber Conference held at Wellington, July, 1896. Wellington, 1896.

Wattles and Wattle-barks (2nd edition). J. H. Maiden. Syduey, 1891.

T smanian Timbers. A. O. Green. Hobart, 1903.

Frestry in its Relation to the Farmer. Robert McNab. Gore, 1903.

\section{American Publications.}

Elements of Forestry. Franklin B. Hough, Ph.D. Cincinnati, 1882.

Forestry in Minnesota. S. B. Green. Delano, 1898.

Familiar Trees. F. S. Matthews. New York, 1901.

Among Green Trees. J. E. Rogers. Chicago, 1902.

Tractical Forestry. John Gifford. New York, 1902.

Principles of American Forestry. S. B. Green. New York, 190:3. 
Publications of the United States Depabtment of Agriculture, BUREAU OF FORESTRY.

\section{Bulletins.}

Timber Physics. Part 1, Preliminary Report.

Forest Influences.

Timber Physics. Part 2, Progress Report.

Report on the Use of Metal Railroad Ties.

Timber: An Elementary Discussion of the Characteristics and Properties of Wood.

Economical Designing of Timber Trestle Bridges.

The Timber-pines of the Southern United States.

Forestry Conditions and Interests of Wisconsin.

Check List of the Forest-trees of the United States.

Osier-culture.

Measuring the Forest-crop.

Systematic Plant-introduction.

The White-pine.

Practical Forestry in the Adirondacks.

Practical Tree-planting in Operation.

A Short Account of the Big Trees of California.

The Forest Nursery.

A Forest Working-plan for Township 40.

Notes on the Red-cedar.

A Working-plan for Forest Lands.

The Western Hemlock.

A History of the Lumber Industry in the State of New York.

\section{Circulars.}

Southern Pine: Mechanical and Physical Properties.

Practical Assistance to Farmers, Lumbermen, and others in handling Forest Lands.

Practical Assistance to Tree-planters.

Suggestions to Prospective Forest Students.

Extracts reprinted from Year-books.

Notes on some Forest Problems. 1898.

Work of the Division of Forestry for the Farmer. 1898.

Progress of Forestry in the United States. 1899.

Practice of Forestry by Private Owners. 1899.

Forest-extension in the Middle West. 1900.

Practical Forestry in the Southern Appalachians. 1900.

The Timber Resources of Nebraska. 1901.

Grazing in the Forest Reserves. 1901.

A Working-plan for Southern Hardwoods, and its Results. 1901. 




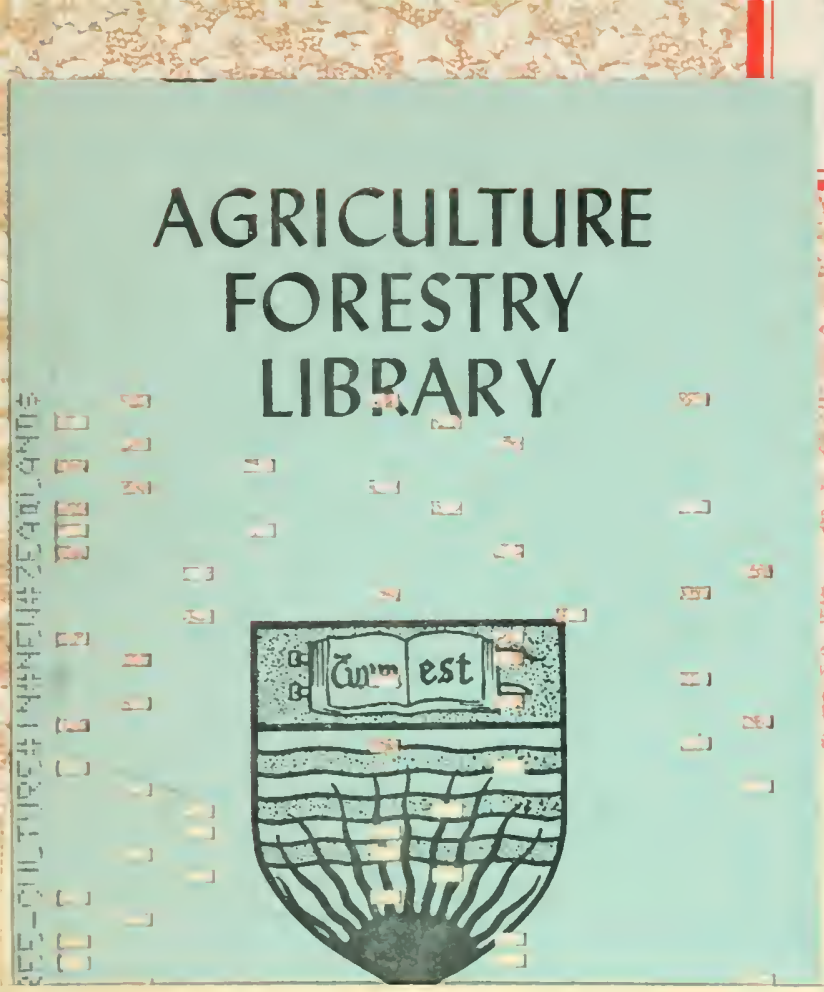

\section{AGRICULTURE FORESTRY LIBPARY}

SD 244 $M 3$

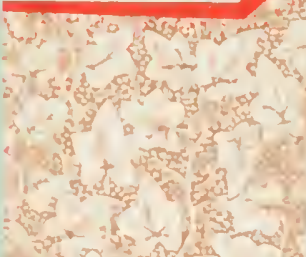

अ?
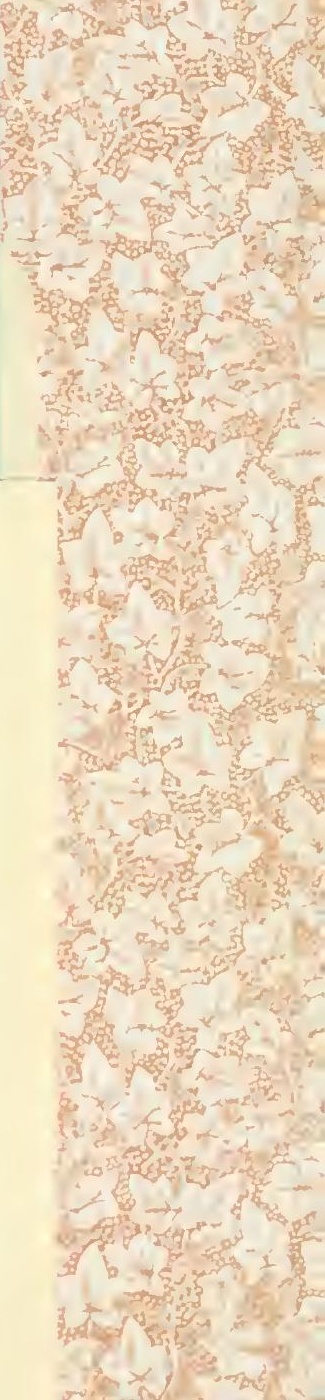


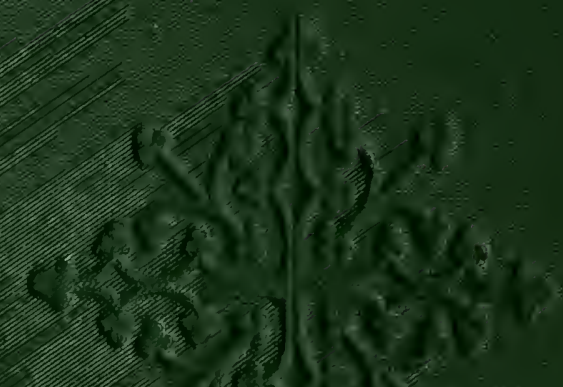

